UNIVERSIDADE DE SÃO PAULO
FACULDADE DE EDUCAÇÃO

WELLINGTON PEREIRA DAS VIRGENS

Problemas Desencadeadores de Aprendizagem na organização do ensino: sentidos em movimento na formação de professores de matemática

São Paulo 



\title{
Problemas Desencadeadores de Aprendizagem na organização do ensino: sentidos em movimento na formação de professores de matemática
}

\author{
Versão Corrigida
}

Tese apresentada ao Programa de Pós-graduação em Educação da Faculdade de Educação da Universidade de São Paulo como requisito parcial para obtenção do título de Doutor em Educação. Área de Concentração: Ensino de Ciências e Matemática.

Orientadora: Prof. ${ }^{a}$. Dr. ${ }^{a}$. Vanessa Dias Moretti 
Autorizo a reprodução e divulgação total ou parcial deste trabalho, por qualquer meio convencional ou eletrônico, para fins de estudo e pesquisa, desde que citada a fonte.

Catalogação na publicação

Serviço de Biblioteca e Documentação

Faculdade de Educação da Universidade de São Paulo

Virgens, Wellington Pereira das

Problemas Desencadeadores de Aprendizagem na organização do ensino: sentidos em movimento na formação de professores de matemática / Wellington Pereira das Virgens ; orientadora, Vanessa Dias Moretti. - 2019

$287 p$.

Tese (Doutorado em Educação) - Programa de Pós-Graduação em Educação, Faculdade de Educação, Universidade de São Paulo, São Paulo, 2019.

Versão corrigida

1. Sentido pessoal 2. Resolução de Problemas 3. Problemas Desencadeadores de Aprendizagem 4. Atividade Orientadora de Ensino 5. Formação inicial de professores de matemática 6. Teoria Histórico-cultural. I. Moretti, Vanessa Dias, orient. II. Título. 
VIRGENS, W. P. das. Problemas Desencadeadores de Aprendizagem na organização do ensino: sentidos em movimento na formação de professores de matemática. 2019. 287p. Tese (Doutorado em Educação) - Programa de Pós-Graduação em Educação, Faculdade de Educação, Universidade de São Paulo, São Paulo, 2019.

Aprovado em:

\section{Banca Examinadora}

Prof. ${ }^{a}$. Dr. ${ }^{a}$. Vanessa Dias Moretti (Presidente)

Instituição: Faculdade de Educação - Universidade de São Paulo - USP

Assinatura:

Prof. Dr. Manoel Oriosvaldo de Moura

Instituição: Faculdade de Educação - Universidade de São Paulo - USP

Assinatura:

Prof. ${ }^{a}$. Dr. ${ }^{a}$. Flávia Dias de Souza

Instituição: Departamento de Educação - Universidade Tecnológica Federal do Paraná UTFPR

Assinatura:

Prof. Dr. Wellington Lima Cedro

Instituição: Instituto de Matemática e Estatística - Universidade Federal de Goiás - UFG

Assinatura:

Prof. Dr. Antônio Carlos Brolezzi

Instituição: Instituto de Matemática e Estatística - Universidade de São Paulo - USP

Assinatura:

\section{Suplentes:}

Prof. Dr. Vinício de Macedo Santos

Instituição: Faculdade de Educação - Universidade de São Paulo - USP

Assinatura: 
Prof. ${ }^{a}$ Dr. ${ }^{a}$. Maria Lúcia Panossian

Instituição: Departamento de Educação - Universidade Tecnológica Federal do Paraná UTFPR

Assinatura:

Prof. ${ }^{a}$ Dr. ${ }^{a}$. Flávia da Silva Ferreira Asbahr

Instituição: Departamento de Psicologia - Universidade Estadual Paulista "Júlio de Mesquita Filho" - Unesp Campus Bauru.

Assinatura:

Prof. ${ }^{a}$ Dr. ${ }^{a}$. Anemari Roesler Vieira Lopes

Instituição: Departamento de Metodologia do Ensino - Universidade Federal de Santa Maria UFSM.

Assinatura:

Prof. a. Dr. a. Maria Lucia Vital dos Santos Abib.

Instituição: Faculdade de Educação - Universidade de São Paulo - USP.

Assinatura: 
À minha amada esposa Sheila, Aos enteados e filhas amados: Sarah, Jefferson, Jessica e Millena. 



\section{Agradecimentos}

A Deus, pelo dom da vida e por ter me dado forças para trilhar esse caminho até aqui.

À minha amada esposa Sheila, por ser minha fiel companheira tanto nas horas felizes, quanto nos momentos de angústia, nas dificuldades e, principalmente, nas crises e estresses que vieram e se foram no decorrer de todos esses anos.

Aos meus enteados Sarah e Jefferson e às minhas filhas Jessica e Millena, que apesar de não saberem ou ainda não terem condições de reconhecer são a grande razão de eu buscar ser e fazer, a cada dia, mais e melhor do que fiz no dia anterior.

Aos meus pais, Ana e Willian, por todos os "não" e todo o esforço que empreenderam para que eu pudesse chegar até aqui munido dos valores éticos que me impulsionam na direção da construção de uma sociedade melhor através da educação.

Aos meus irmãos Jefferson e Werverson, pelo carinho e pela cumplicidade durante toda uma infância, tão simples quanto feliz, que possibilitou uma união fraternal que faz com que, juntos, sejamos mais fortes.

Ao meu tataravô Joaquim e minha tataravó Lostriana, in memoriam, que foram arrancados do seio da mãe África e trazidos, à força, para serem escravos aqui e que morreram sem poder realizar o sonho de retornar para sua terra natal como pessoas livres, mas que, apesar de tudo, aqui deixaram as sementes que, agora, começam a alcançar a justiça que Ihes é devida, sendo minha formação até aqui mais do que uma homenagem, mas também parte do pagamento desta dívida.

À minha avó, Edite, que mesmo sem saber ler e nem escrever sempre foi grande incentivadora da minha educação escolar e que aceitou de bom grado a responsabilidade de cuidar de mim e de meus irmãos, ainda pequenos, enquanto meus pais precisavam trabalhar.

Aos queridos demais familiares, tios, tias, sobrinhos, sobrinhas, primos, primas, cunhados, cunhadas que me perdoarão pela não citação nominal, compreendendo que prefiro este agradecimento geral do que o risco de cometer a imperdoável injustiça de, eventualmente, esquecer-me de alguém.

À professora Vanessa Dias Moretti, pela confiança depositada, pelos momentos de cumplicidade que culminaram no que eu gosto de chamar, sem exagero e com grande sinceridade, de "maternidade acadêmica", em referência ao grande companheirismo com que realizamos essa jornada de conhecimento e que, certamente, permanecerá uma sincera amizade.

Aos colegas do GEPPEDH, grupo de estudos que eu aprendi a admirar e amar, especialmente, aos amigos Iraji, Lidiane, Raquel, Vanúsia, Fernanda, Juliana, Fábio, Adriane e Alex. 
Aos professores e à gestão acadêmica e administrativa da Faculdade de Educação da USP, que têm verdadeiro compromisso com a formação dos alunos, bem como com a valorização da carreira docente e com uma educação pública, universal, laica e de qualidade, em especial ao professor doutor Nilson José Machado, que acreditou em um projeto inicial, mas que, em razão das opções teóricas e metodológicas que adotamos, concordou, de bom grado, com uma mudança de orientador.

Aos professores Manoel Oriosvaldo de Moura e Wellington Lima Cedro, pelas importantíssimas contribuições para essa versão do trabalho de pesquisa, apresentadas por ocasião da minha qualificação.

Aos professores Manoel Oriosvaldo de Moura, Wellington Lima Cedro, Flávia Dias de Souza, Antônio Carlos Brolezzi, Maria Lúcia Panossian, Flávia da Silva Ferreira Asbahr, Vinicio de Macedo Santos, Anemari Roesler Vieira Lopes e Maria Lucia Vital dos Santos Abib pelo aceite em compor a comissão avaliadora e participar, direta ou indiretamente, da apresentação pública dos resultados desta pesquisa e dos debates que suscitamos a partir de nossas conclusões.

À gestão acadêmica e administrativa do Instituto Federal de São Paulo - IFSP-SP, em especial na figura da diretora de pesquisa, extensão e pós-graduação do campus São Paulo, Mariana Pelissari Monteiro Aguiar Baroni, e do diretor geral, Luis Cláudio de Matos Lima Júnior, por promoverem e incentivarem a capacitação e qualificação dos servidores, inclusive possibilitando sediar a realização do experimento formativo que subsidia as conclusões dessa pesquisa.

Aos professores do IFSP-SP, pelo apoio e por acreditarem na formação continuada como premissa da melhoria da qualidade do trabalho docente, citando de maneira especial, para representar todos os outros, os colegas da subárea de matemática.

Aos servidores técnicos administrativos do campus Guarulhos da Universidade Federal de São Paulo, pelo apoio e companheirismo, sobretudo na primeira metade do curso, em especial os amigos do Setor de Apoio Pedagógico, Andreza, Daniela, Diego, Elaine, Eliane e Simone.

A todos os alunos da Licenciatura em matemática do IFSP-SP, por se dedicarem à formação para o exercício da docência e por manter viva a esperança de uma educação humanizadora, em especial àqueles que participaram das disciplinas de Prática de Ensino e que consentiram para a produção dos dados analisados durante a pesquisa. 
É precisamente com o auxílio dos problemas propostos, da necessidade que surge é estimulada, dos objetivos colocados perante o adolescente que o méio social circundante o motiva e o leva a dar esse passo decisivo no desenvolvimento do seu pensamento.

Lev semionovich vygotsky (2001, p. 171). 



\section{Resumo}

Esta pesquisa investigou o movimento dos sentidos pessoais sobre o papel do Problema na aprendizagem da organização do ensino, durante a formação inicial de professores de matemática. Adotando referenciais teóricos da perspectiva histórico-cultural e da teoria da atividade, propostas por Vygotsky e Leontiev, respectivamente, buscamos acompanhar o movimento a partir dos sentidos pessoais iniciais de sete licenciandos, que tinham origem em suas experiências pessoais em eventos que eles classificavam como representativos de ações que obtiveram "sucesso" no ensino. Esses sentidos iniciais remetiam, de modo geral, a uma compreensão pragmática de que o Problema seria recurso de aplicação de definições, propriedades e algoritmos já ensinados e cujas soluções poderiam remeter a outras aplicações no cotidiano. Compreendendo que a licenciatura deve ser o momento em que os professores em formação inicial devem aprender a ensinar, realizamos um experimento formativo que, no contexto de uma metodologia materialista histórico-dialética, pressupunha a necessidade de planejar atividades de regência, mediadas por Problemas, para o estágio supervisionado da licenciatura. No decorrer do experimento formativo, foram promovidas ações que propunham Situações Desencadeadoras de Aprendizagem que não pretendiam apenas verificar a solução dos Problemas matemáticos em si, mas possibilitar a análise do processo de reconhecimento daquilo que seria essencial para aprender a ensinar os conceitos impregnados naquelas situações, remetendo dessa forma ao Problema Desencadeador de Aprendizagem e seu papel na aprendizagem da organização do ensino. Os resultados da pesquisa indicam que a atividade de formação para a docência é aquela que visa a tomada de consciência do sujeito sobre sua condição de sujeito na atividade pedagógica, já que o movimento dos sentidos dos licenciandos contribuíram para que eles se reconhecessem, mais do que como estudantes de matemática, principalmente, como professores de matemática em formação.

Palavras-chave: Sentido pessoal. Resolução de Problemas. Problemas Desencadeadores de Aprendizagem. Atividade Orientadora de Ensino. Formação inicial de professores de matemática. Teoria Histórico-cultural. 



\begin{abstract}
This research investigated the movement of the personal senses about the aim of use Problems in the learning organization of the teaching during the undergraduate math teacher training. Adopting theoretical references from the historical-cultural perspective and the theory of activity, proposed by Vygotsky and Leontiev, respectively, we sought to follow the movement from the initial personal senses of seven students of the undergraduate, which originated in their personal experiences in events that they classified as representative of actions that had "success" in teaching. These initial sense generally referred to a pragmatic understanding that the Problem would be a resource of application of definitions, properties and algorithms already taught and whose solutions could refer to other applications in daily life. Understanding the undergraduate should be the moment when the teachers in initial formation should learn how to teach, we conducted a formative experiment that, in the context of a materialist historical-dialectical methodology, presupposed the need to plan activities of regency for the supervised stage of the course, highlighting the use of Problems. During of the formative experiment, actions were promoted that permeated the proposition of Learning Trigger Situations of mathematical concepts that were not only intended to verify the solution of the Mathematical Problems themselves, but to enable the analysis of the process of recognition of what would be essential for the teaching of their concepts impregnated in those situations, thus referring to the Learning Trigger Problem and its use in learning the organization of teaching. The results of the research indicate that the activity of training for teaching is one that aims at the awareness of the subject about his condition of subject in the pedagogical activity, since the movement of the senses of the licenciandos contributed to that they recognized, more than as math students, mainly as math teachers in formation.
\end{abstract}

Keywords: Personal sense. Problems solving. Learning Triggers Problems. Teaching Activity. Undergraduate math teacher training. Historical-cultural theory. 



\section{Lista de abreviaturas}

AOE Atividade Orientadora de Ensino

BNCC Base Nacional Comum Curricular

CAPES Coordenação de Aperfeiçoamento de Pessoal de Nível Superior

DCN Diretrizes Curriculares Nacionais

EF Experimento Formativo

ENEM Exame Nacional do Ensino Médio

FEUSP Faculdade de Educação da Universidade de São Paulo

FPS Funções Psicológicas Superiores

HM História da matemática

IFSP Instituto Federal de São Paulo

IFSP-SPO Instituto Federal de São Paulo - Campus São Paulo

INEP Instituto Nacional de Estudos e Pesquisas Educacionais Anísio Teixeira

LDB Lei de Diretrizes e Bases da Educação Nacional

NTCM National Council of Teachers of Mathematics

PCN Parâmetros Curriculares Nacionais

PCNEM Parâmetros Curriculares Nacionais para o Ensino Médio

PDA Problema Desencadeador de Aprendizagem

PEF Pré-experimento Formativo

PPC Projeto Pedagógico de Curso

RES Relatório de Estágio Supervisionado

RTC Registro de Tarefa Coletiva

RTI Registro de Tarefa Individual

SAEB Sistema de Avaliação da Educação Básica

SARESP Sistema de Avaliações da Rede Pública Estadual de São Paulo

SDA Situação Desencadeadora de Aprendizagem

TA Teoria da Atividade

TAI Transcrição de Áudio Individual

TAC Transcrição de Áudio Coletivo

TCLE Termo de Consentimento Livre e Esclarecido 
THC Teoria Histórico-cultural

UNICAMP Universidade Estadual de Campinas

UNIFESP Universidade Federal de São Paulo

USP Universidade de São Paulo 


\section{Lista de Figuras}

Figura 1: Relações do Sistema de Práticas Educativas ................................................36

Figura 2:Exemplos de Problema, segundo os PCNEM ….......................................53

Figura 3: Estrutura Curricular da Educação Básica, segundo a BNCC ........................58

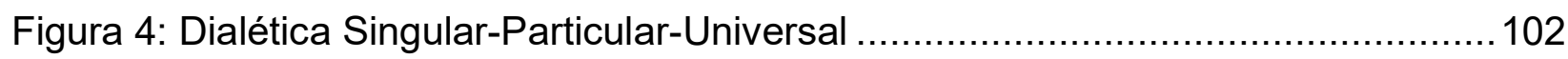

Figura 5: Heurísticas e estratégias de resolução de Pólya, no original e na tradução. 106

Figura 6: Ilustrações da definição de Problema por Dante ........................................111

Figura 7: Organização de Episódios e Isolados .................................................. 151

Figura 8: Imagem da solução dos alunos durante a regência da licencianda ...............164

Figura 9: Imagem das medições dos alunos durante a regência do licenciando ..........170

Figura 10: Imagem da reta numérica com as representações do Lado A da área de Plantio

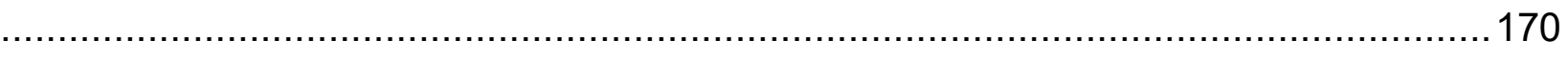

Figura 11: Imagem da reta numérica com a solução do Problema............................171

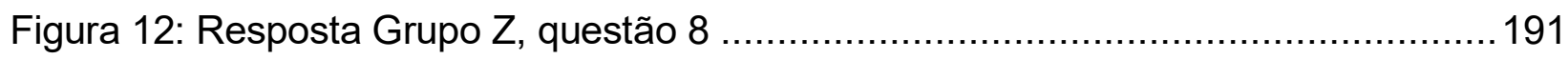

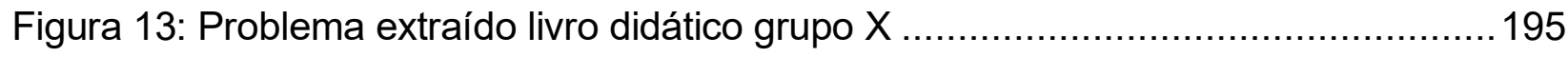

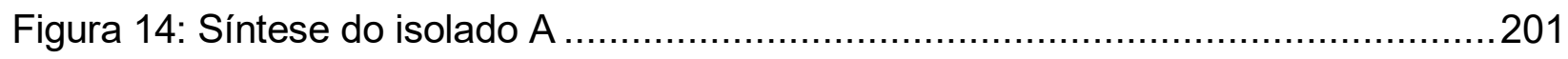

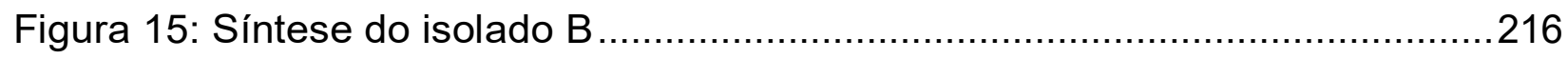

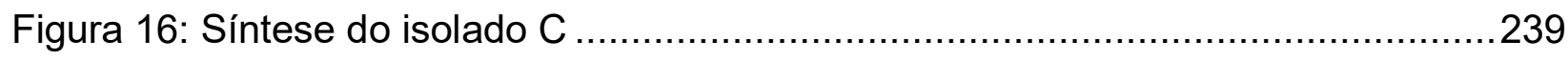

Figura 17: Síntese do movimento verificado na pesquisa ....................................258 



\section{Lista de Quadros}

Quadro 1: Vínculos entre os estágios supervisionados e as disciplinas de Prática de Ensino 68

Quadro 2: Heurísticas e estratégias de resolução de Pólya. 107

Quadro 3: Resumo encontros das disciplinas de Prática de Ensino $\left(1^{\circ}\right.$ semestre de 2017 Etapa exploratória pré-experimento formativo)

Quadro 4: Resumo encontros do experimento formativo ( $2^{\circ}$ semestre de 2017 -

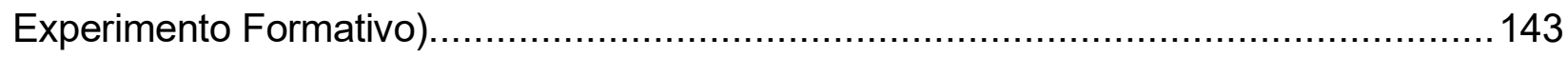

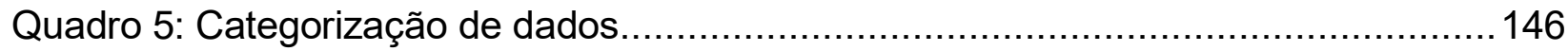

Quadro 6: Sentidos pessoais iniciais de licenciandos sobre Problema .......................180

Quadro 6: Apresentação de isolados e episódios ................................................181

Quadro 7: Agrupamento para o experimento formativo.......................................... 182

Quadro 8: Resumo das considerações dos grupos sobre o Jogo de Adivinhação ......219 



\section{Sumário}

INTRODUÇÃO.

1. A FORMAÇÃo INICIAL DE PROFESSORES DE MATEMÁTICA NO BRASIL .33

1.1 A formação do matemático e a formação do professor de matemática......34

1.2 Textos oficiais que impactam na formação de professores de matemática e

o papel do Problema nestes textos 39

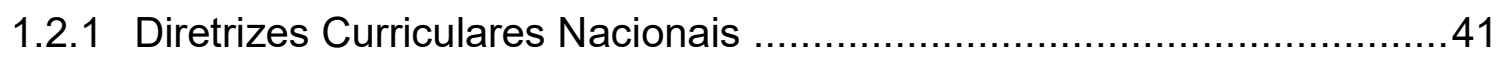

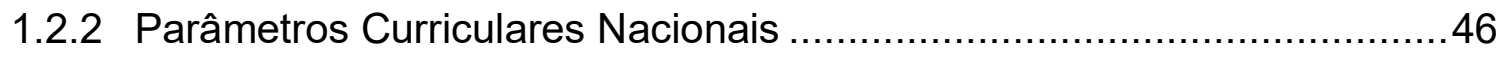

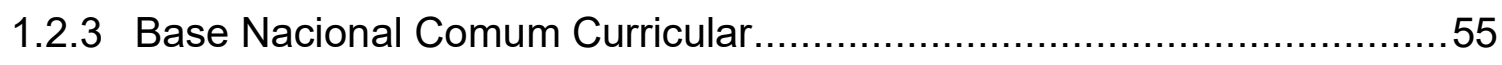

1.2.4 Projeto Político Pedagógico do curso de Licenciatura em matemática

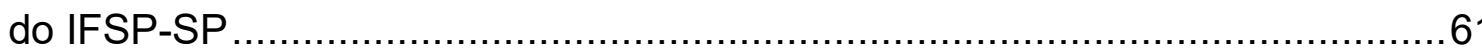

1.3 O Estágio Supervisionado nos cursos de Licenciatura em matemática .....72

2. O Conceito de Problema e a Teoria Histórico-Cultural ..............................78

2.1 Teoria Histórico-cultural: aspectos da aprendizagem e desenvolvimento

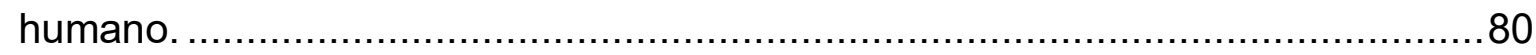

2.1.1 Aprendizagem e Desenvolvimento no contexto da THC .......................82

2.1.2 Significação, Significados e Sentidos sobre Problemas.........................90

2.1.3 Implicações teórico-metodológicas da THC ....................................... 97

2.2 Indícios de Sentidos sobre o papel do Problema no ensino de matemática: o

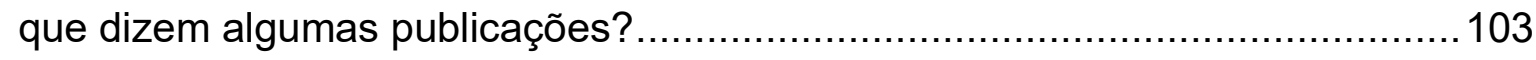

2.3 O Significado de Problema na perspectiva histórico-cultural...................117

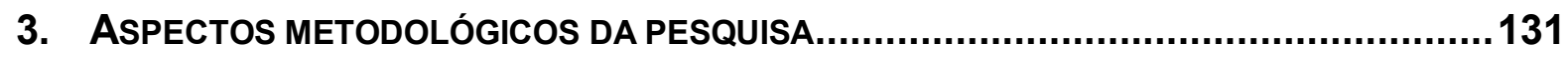

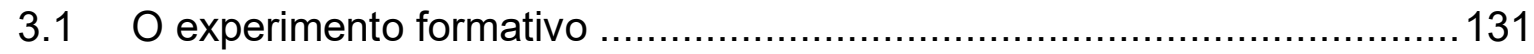

3.1.1 Etapas exploratória pré-experimento formativo ….............................133

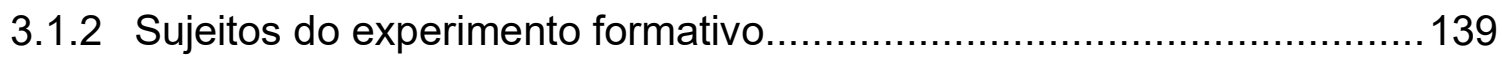

3.1.3 Procedimentos do experimento formativo....................................... 142

3.2 Aspectos metodológicos da análise de dados ...................................... 146 
4. RelaÇões ENTRE CONCEITO de PDA E O MOVIMENTO dos SENTIDOS PESSOAIS NA FORMAÇÃO INICIAL DE PROFESSORES DE MATEMÁTICA............................................ 153

4.1 Sentidos Pessoais Iniciais sobre o papel do Problema nas aulas de

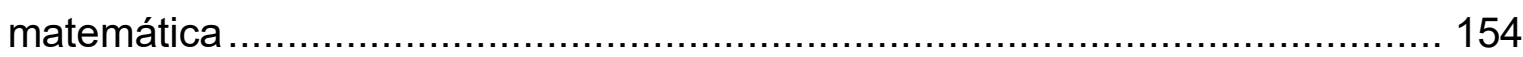

4.2 O protagonismo do Problema na organização da AOE ......................... 181

4.2.1 Episódio A1: O reconhecimento da necessidade da necessidade. ...... 183

4.2.2 Episódios A2: Superação da proposição de Problemas "prontos"........ 190

4.2.3 Síntese do isolado A ............................................................... 199

4.3 O papel dos estudos de História da matemática na organização da atividade

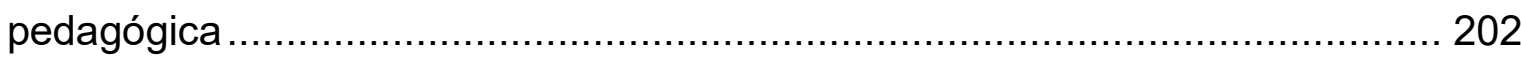

4.3.1 Episódio B1: Suscitando historicamente a essência da necessidade do

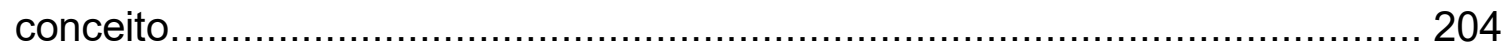

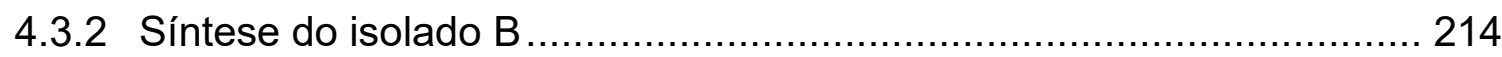

4.4 Relações entre o significado de PDA e o movimento dos sentidos pessoais dos licenciandos sobre o papel do Problema nas aulas.................................. 217

4.4.1 Episódio C1: O PDA no planejamento da SDA............................... 218 4.4.2 Episódio C2: O uso de Problemas na regência de estágio: uma aproximação da ideia de PDA. ............................................................ 225

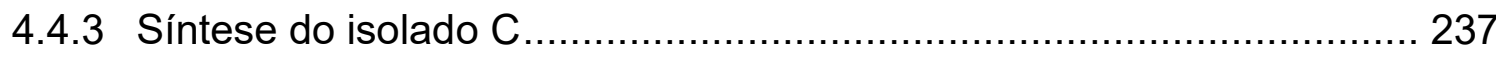

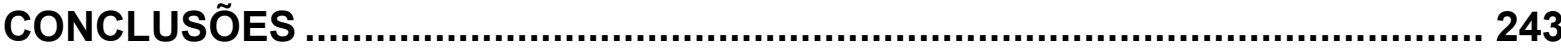

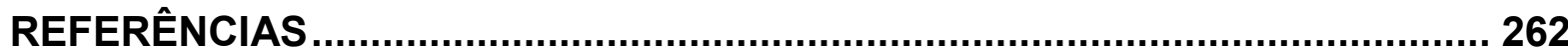

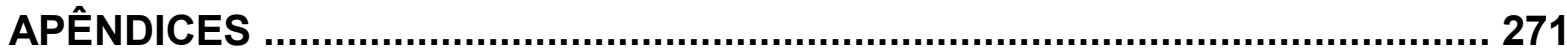

ANEXOS 


\section{INTRODUÇÃO}

Nossa trajetória pessoal remete ao reconhecimento precoce do valor e do potencial transformador da educação. Tendo sido estudante de escola pública durante todo o processo de escolarização básica, logramos ingressar, ainda na adolescência, em um curso de aprendizagem industrial vinculado à contratação como menor aprendiz em uma indústria metalúrgica da cidade onde morávamos. Nossa afinidade pessoal pela matemática, que já se verificava pelo desempenho que alcançávamos na matéria escolar, foi reforçada pela formação técnica que, além da integração ao mercado de trabalho formal, possibilitou a aplicação daquele conhecimento nos processos laborais que estávamos aprendendo. Desse modo, o contato cada vez mais frequente com trabalhos que envolviam aquela disciplina escolar potencializou nossa opção pelo ingresso em um curso superior na área da matemática.

Filho mais velho de uma família humilde, o ingresso no mercado de trabalho formal aos quinze anos dificultou a dedicação integral ou exclusiva aos estudos de modo que, juntamente com o fato de serem inexistentes, à época, as instituições públicas que permitissem conciliar estudo e trabalho, tivemos que optar por uma instituição privada de ensino superior e a variável "mensalidade" passou a ser fundamental na escolha da carreira. Apesar de, àquela altura, possuir grande afinidade pela matemática e pouca pretensão quanto ao exercício da docência, o valor cobrado pela instituição acabou sendo determinante para o ingresso na licenciatura em matemática.

Foi este o contexto a partir do qual emergiu nosso motivo para o ingresso na licenciatura em matemática. No decorrer daquele curso, a partir de um pedido de demissão voluntária, fomos impelidos a ingressar na profissão docente como professor eventual da rede pública de São Paulo. A afinidade com o conteúdo matemático potencializou um bom desempenho acadêmico de modo que, antes ainda de concluir o curso, logramos a aprovação em concurso público para professor da rede pública paulista e, assim que concluímos nossa graduação, fomos empossados no referido cargo e assumimos a titularidade das aulas de matemática em uma escola pública na região periférica da cidade, próxima de onde ainda residíamos. Foi no âmbito daquela atuação 
como professor que iniciou-se nosso interesse pelos Problemas $^{1}$ e seu papel na atuação profissional do professor e na aprendizagem dos alunos.

Incomodava-nos o que classificávamos como "baixo desempenho" dos alunos em momentos de avaliação, principalmente nas chamadas "avaliações externas" ${ }^{2}$, a despeito de termos apresentado os conteúdos matemáticos envolvidos em tais avaliações previamente. Ainda que os conteúdos Matemáticos do currículo fossem exercitados até a exaustão, os alunos, invariavelmente, apresentavam resultados insatisfatórios quando eram submetidos à necessidade de resolver Problemas - em certas avaliações, por exemplo - mesmo que tais Problemas fossem, a nosso ver à época, meras aplicações diretas dos mesmos conteúdos que já havíamos ensinado. Essa contradição fez com que buscássemos tentar compreender melhor os diversos aspectos que envolvem o desenvolvimento da capacidade de resolver Problemas e a aprendizagem da matemática na educação básica, de maneira geral.

Os Problemas sempre estiveram presentes na matemática, seja como ponto de partida da produção do conhecimento matemático ou como instrumento de aplicação, disseminação ou verificação desse conhecimento. São inúmeros os trabalhos que referenciam, na História da Matemática, coleções de Problemas de vários tipos, como, por exemplo, o Papiro de Rhind, o Papiro de Moscou, Os Elementos - de Euclides, entre outros. A presença e importância dos Problemas na matemática, no entanto, parece ter sido apropriada pelas práticas especificamente escolares, relacionadas aos processos de ensinar e aprender matemática, só recentemente ${ }^{3}$. Popularmente, "saber" matemática

\footnotetext{
1 O termo "problema" é originado pela expressão latina "problēma ătis", que significa estar diante de alguma dificuldade, questão ou obstáculo. A variação semântica decorrente dos possíveis significados da palavra nos leva a estabelecer distinção entre os termos "Problema" (com inicial em letra maiúscula) e "problema" (inteiramente com letras minúsculas). A grafia "Problema" é utilizada, em um sentido mais estrito, quando nos referimos a um Problema de matemática. Já o termo "problema" é utilizado com sentido mais geral, como sinônimo de "dificuldade", "defasagem", "falha" ou "não-conformidade". Nas citações diretas, no entanto, mantemos a grafia original, com a expectativa de que o contexto permita a interpretação.

2 No estado de São Paulo os alunos são submetidos anualmente a avaliações de desempenho que subsidiam políticas de investimento e qualificação da educação pública.

${ }^{3}$ De acordo com as conclusões de pesquisa anterior, VIRGENS (2014), a referência direta à importância dos Problemas nas práticas escolares verifica-se em manuais de ensino apenas a partir do século XX. Em relação à presença milenar dos Problemas nos documentos matemáticos, essa presença nos bancos
} 
é sinônimo de resolver Problemas matemáticos, mas aspectos relacionados aos estudos da importância dos Problemas para as práticas de ensino e aprendizagem passaram a ser pautados no contexto da matemática escolar somente no decorrer do século XX, sobretudo a partir dos trabalhos do matemático húngaro George Pólya.

Partindo de uma hipótese inicial de que as dificuldades dos alunos estavam mais intimamente relacionadas aos processos de desenvolvimento cognitivo e educacional deles próprios do que, propriamente, aos conteúdos matemáticos ou às nossas próprias opções metodológicas e didáticas de ensino, passamos a estudar com maior interesse diretrizes propostas para o desenvolvimento da capacidade de resolver Problemas. Para além das importantes primeiras apropriações teóricas a tal respeito, pudemos conhecer, ainda, algumas conclusões de diversos autores e textos oficiais acerca do que se consideraria o papel dos Problemas nas aulas de matemática. Uma dessas conclusões foi a que se apresentou resumida nos Parâmetros Curriculares Nacionais - PCN de matemática do Ensino Fundamental, onde há a defesa de que

O ponto de partida da atividade matemática não é a definição, mas o problema. No processo de ensino e aprendizagem, conceitos, ideias e métodos matemáticos devem ser abordados mediante a exploração de problemas, ou seja, de situações em que os alunos precisem desenvolver algum tipo de estratégia para resolvê-las. (BRASIL, 1998, p. 32).

Essa indicação dos PCN foi tomada como uma provocação que nos demandava um movimento de mudança em nossas práticas pedagógicas, já que ia de encontro às práticas docentes que adotávamos até então, que seguiam um modelo "tradicional" que partia de uma definição, apresentava propriedades e exercícios resolvidos por nós mesmos, como modelos a serem seguidos para a solução de exercícios propostos e para a resolução de Problemas, passando para uma avaliação (geralmente, uma prova escrita com questões similares às que já havíamos resolvido anteriormente). Ao sugerir que o Problema era ponto de partida da atividade ${ }^{4}$ matemática, e não ponto de chegada, o texto

escolares pode ser considerada recente.

${ }^{4}$ Nos PCN o termo "atividade" é tomado no senso comum, como sinônimo de ação ou execução de alguma tarefa. Em nossa pesquisa, no entanto, a atividade é um conceito teórico estabelecido a partir das contribuições de Leontiev, do qual decorrem também os conceitos de "atividade pedagógica", "atividade de ensino", "atividade de aprendizagem" e outros que serão melhor apresentados no capítulo 2. 
oficial nos forçava a questionar fortemente nossas próprias práticas e, mais do que isso, a questionar nosso processo de formação como professor.

A fim de compreender um pouco mais a gênese do papel e da importância dos Problemas nas aulas de matemática na educação básica, voltamos nosso foco de interesse para os processos históricos do que seria um bom Problema, estudo esse que culminou na nossa dissertação de mestrado intitulada "A resolução de Problemas de aritmética no Ensino Primário: um estudo das mudanças no ideário pedagógico (19201940) ${ }^{5 "}$, defendida no ano de 2014. Naquela pesquisa, que investigou aspectos da presença e do papel dos Problemas nos materiais didáticos destinados ao uso dos professores em sala de aula nos primeiros anos de escolarização, pudemos concluir que houve uma mudança relevante no conceito do que seria - o que chamamos, naquele contexto, de-Bom Problema, de acordo com as defesas dos autores daqueles materiais, a partir do final do século XIX e décadas iniciais do século XX, em um momento histórico em que se intensificava um debate pedagógico que se caracterizava pelo embate entre diferentes grupos de "intelectuais" e estudiosos dos processos educativos pelo monopólio do signo do Novo.

Essas mudanças, de maneira bastante sintética, consistiam na superação da compreensão de que um Bom Problema seria aquele que remetesse à possibilidade de aplicação dos conteúdos ensinados previamente em sala de aula, como modelos, em prol das ideias sobre Problema que iam em direção ao entendimento de que o Bom Problema seria "aquele que assumisse um contexto ligado à realidade da criança, que fossem úteis à vida cotidiana e que tivessem potencial para despertar o interesse da criança" (VIRGENS, 2014, p. 75). Foi naquele período histórico também que os Problemas passaram a ser apreciados como método para se ensinar aritmética e as questões de aplicação direta daquilo que já havia sido ensinado em sala de aula foram deixando de ser consideradas "Problemas" passando a ser reconhecidas como recursos de aplicação (VIRGENS, 2014).

5 O texto completo da dissertação está disponível no endereço eletrônico https://repositorio.ufsc.br/handle/123456789/126744. 
Outras pesquisas desenvolvidas no campo da Educação matemática ratificam que o Problema é, atualmente, objeto de interesse recorrente, mas permitem uma inferência de que o conceito de Problema seria sabido, a priori, pelos professores. Como exemplo disso, realizamos uma busca, com finalidade quantitativa, no catálogo de teses e dissertações da CAPES, em que demandamos os termos "resolução de problemas" e "matemática" e obtivemos retorno de 43.115 (quarenta e três mil, cento e quinze) resultados, o que corrobora nossa indicação de que esse é um tema de largo interesse para os campos de pesquisas que envolvem a matemática. Nesse conjunto encontram-se inúmeros estudos que tratam de Problemas matemáticos e aplicações imediatas (não relacionadas, necessariamente, com os processos educativos que envolvam o ensino e a aprendizagem de matemática). Refinando os filtros de busca para incluir apenas resultados que remetessem à resolução de Problemas na educação matemática, o sistema de busca retorna 5.279 (cinco mil, duzentos e setenta e nove) resultados, ou seja, pouco mais do que $12 \%$ dos trabalhos que envolvem resolução de Problemas naquele banco de dados retornam pesquisas realizadas com foco em aspectos do ensino ou da aprendizagem de matemática.

Mais um refinamento, fazendo incluir apenas pesquisas voltadas para os processos de formação de professores, reduz os resultados para 219 (duzentos e dezenove). Notase que apenas $4 \%$ das pesquisas que tratam da resolução de Problemas na educação matemática foram realizadas com destaque especial aos processos formativos do professor que ensina matemática, o que pode ser interpretado como uma tendência de que os Problemas sejam importante recurso metodológico sem, no entanto, enfatizar a necessidade de uma formação dos professores especificamente voltada à utilização de tal recurso.

Em grande parte dessas pesquisas podemos destacar diferentes abordagens da resolução de Problemas, mas na maioria delas o tema é abordado indiretamente, como uma das possibilidades formativas escolhidas dentre as alternativas próprias dos arcabouços teórico-metodológicos adotados por seus autores. As opções metodológicas dos pesquisadores colocam em pauta discussões sobre os Problemas e aspectos de sua resolução na formação de professores, segundo as quais os mesmos representariam metodologias prontas para o ensino de matemática, tratando a Resolução de Problemas 
como um fim em si mesma, ou seja, os professores deveriam aprender técnicas a serem ensinadas aos alunos para resolver qualquer tipo de Problema.

Ainda que o Problema seja objeto de variados estudos matemáticos e da educação matemática, os professores em formação inicial, como indicia nosso levantamento bibliográfico, não recebem uma formação intencionalmente organizada para que possam compreender tais Problemas como instrumentos importantes para a organização de suas práticas pedagógicas. Os Problemas são, geralmente, tratados como meros recursos de aplicação de conteúdos que possuem algum contexto relacionado ao cotidiano e as perspectivas metodológicas que remetem ao papel do Problema nas práticas docentes indicam uma naturalização da ideia segundo a qual saber matemática é condição suficiente para que o professor apresente Problemas adequados ao propósito de ensinar.

Nesse contexto, ao iniciar nossa pesquisa de doutoramento, admitimos que as lacunas observadas na formação inicial de professores, sobre o papel dos Problemas nas próprias práticas pedagógicas, poderiam ser minimizadas a partir de um processo formativo que buscasse desnaturalizar a compreensão de que o conhecimento relacionado à organização do ensino seria consequência "natural" do conhecimento matemático, ou um apêndice deste, nos cursos de formação de professores.

Foi nesse contexto também que nos aproximamos dos construtos teóricos e metodológicos do materialismo histórico-dialético, das teorias histórico-cultural e da atividade, com o objetivo de investigar o movimento dos sentidos pessoais dos alunos da licenciatura em matemática sobre o conceito de Problema e sobre seu papel na organização do ensino. Por isso propusemos a realização de um movimento formativo aos estudantes do curso de Licenciatura em matemática do Instituto Federal de São Paulo, onde atuamos como docente.

Buscávamos superar a mera preparação dos futuros professores para resolver e ensinar a resolver Problemas modelares mediante a aplicação direta de definições e propriedades de conceitos matemáticos, assumindo a necessidade de uma formação intencionalmente voltada à aprendizagem de aspectos da docência que enfatizassem sentidos sobre o papel do Problema na organização do ensino. Entendíamos que, apesar dos discursos recorrentes acerca da importância dos Problemas para o ensino e para a aprendizagem de matemática, as práticas mais recorrentes remetiam à utilização de 
questões contextualizadas de aplicação direta de conteúdos matemáticos presentes nos currículos, retiradas de livros didáticos ou apresentadas como modelos voltados à preparação para a realização de provas e exames específicos. Acreditando que tal caracterização de Problema remetia, na verdade, ao exercício de classificação imediata e reprodução de situações idênticas apresentadas modelarmente e que pouco contribuíam para a apropriação da produção cultural humana ou para o exercício da cidadania, passamos a entender os Problemas, também, como recursos didáticos desencadeadores de aprendizagem da organização da atividade pedagógica, em uma perspectiva Histórico-cultural, como mostraremos no capítulo 2.

Considerando tal ferramental teórico-metodológico, da teoria Histórico-cultural, realizamos uma formação que pudesse promover a aprendizagem da organização dessa atividade pedagógica. Licenciandos do curso de licenciatura em matemática do IFSP foram convidados a planejar sua regência de estágio supervisionado admitindo que o Problema assumisse um papel protagonista na organização da proposta. Nosso objetivo, como já indicamos, era o de perceber indícios de sentidos pessoais iniciais dos licenciandos acerca do papel do Problema nas práticas de ensino de matemática, bem como acompanhar o movimento de tais sentidos pessoais que, eventualmente, convergissem para a compreensão do Problema como desencadeador de aprendizagem.

Acompanhar esse movimento formativo, entendemos, nos autorizaria a admitir a necessidade de uma formação de professores que superasse a ideia de que qualquer Problema seria bom desde que aplique os conceitos "ensinados" previamente, para reconhecer a unidade dialética entre os aspectos lógico e histórico dos conceitos através dos Problemas e para consolidação destes como mediadores essenciais nos processos de ensino e de aprendizagem e, portanto, para a organização do ensino, em benefício de uma educação humanizadora e em detrimento de práticas tradicionais voltadas à reprodução a-histórica de modelos.

Nossa pesquisa, portanto, remete à compreensão a respeito do movimento dos sentidos dos licenciandos sobre o papel do Problema durante o ensino de matemática, a partir do processo de formação de professores ancorado pelos pressupostos da Teoria Histórico-cultural, em especial a Teoria da Atividade e a Atividade Orientadora de Ensino. 
A produção dos dados coletados que subsidiaram nossa análise desse movimento se deu no contexto de um experimento formativo. Este foi realizado no âmbito das disciplinas de Prática de Ensino 3 e 4 que abarcavam ${ }^{6}$ o estágio supervisionado do curso de licenciatura do IFSP, à época. Propusemos, como parte do planejamento e da organização das regências de aula durante o estágio, uma formação intencionalmente direcionada à elaboração ou adaptação de Problemas que pudessem ser desencadeadores de aprendizagem do conceito a ser ensinado na regência.

Em consonância com os códigos de ética da Universidade de São Paulo - USP e do próprio Instituto Federal de São Paulo - IFSP, os estudantes matriculados nas disciplinas foram convidados a participar da pesquisa, sendo a referida participação facultativa e independente do aproveitamento acadêmico nas disciplinas, de modo que aqueles que aceitaram participar do projeto formalizaram esse aceite em termo de consentimento livre e esclarecido. Ainda em respeito às normatizações éticas das instituições envolvidas na pesquisa, neste texto as identidades dos participantes estão preservadas.

Os resultados da nossa pesquisa estão apresentados a seguir, organizados em quatro capítulos. No primeiro capítulo apresentamos considerações sobre a formação inicial de professores de matemática no Brasil, em que buscamos tratar da necessária superação da formação de matemáticos para ensinar matemática em prol de uma formação de professores que articula saberes matemáticos e pedagógicos para uma educação matemática. Também tratamos da constituição dos cursos de licenciatura em matemática, em especial o curso do IFSP, onde os sujeitos de nossa pesquisa estavam matriculados. Exercitamos a defesa de uma licenciatura que possua ênfase na formação do professor que ensina matemática, superando concepções de cursos que formam matemáticos para "ensinar" e que tratam os conhecimentos pedagógicos e as especificidades do fazer docente como apêndices ou "habilidades naturais".

No segundo capítulo, apresentamos aspectos da caracterização das ideias relacionadas ao Problema e seu uso nas aulas de matemática, bem como tratamos dos

${ }^{6}$ O tempo verbal se justifica em razão da alteração na proposta curricular do curso, ocorrida após a realização do experimento formativo. 
aspectos teóricos que subsidiam nosso arcabouço metodológico. Nesse percurso, procuramos demonstrar as relações dialéticas entre um processo de significação de Problema e um movimento de constituição de sentidos pessoais sobre o papel dos Problemas no ensino de matemática.

No capítulo três, tratamos de apresentar os aspectos metodológicos da pesquisa, tratando do materialismo histórico-dialético enquanto método de investigação, sobre o experimento formativo como fonte de produção e coleta de dados e sobre a organização da apresentação de nossa análise em isolados e episódios. É nesse capítulo que descrevemos o nosso experimento formativo, apresentando os sujeitos participantes da pesquisa, os encontros formativos e as ações realizadas.

No capítulo quatro, analisamos os dados produzidos e coletados, à luz do referencial teórico e metodológico apresentados nos capítulos dois e três, focalizando nosso objetivo de pesquisa de acompanhar o movimento nos sentidos pessoais dos licenciandos sobre o papel do Problema na organização do ensino.

Por fim, apresentamos nossas conclusões a respeito do referido movimento dos sentidos sobre Problemas e sobre as implicações desse movimento para a formação inicial de professores de matemática.

Enfim, os resultados de tal investigação estão apresentados a seguir, buscando argumentos para subsidiar o debate acadêmico em torno de qual formação de professores potencializa a adoção de Problemas a serviço do ensino e da aprendizagem de matemática em benefício de uma educação humanizadora. 


\section{CAPÍTULO 1}

A FORMAÇÃo INICIAL DE PROFESSORES DE MATEMÁTICA NO BRASIL 


\section{A FORMAÇÃO INICIAL DE PROFESSORES DE MATEMÁTICA NO BRASIL}

A busca da identificação do profissional em educação matemática nos permite caracterizá-lo como um educador que se utiliza da matemática como instrumento formador.

Manoel Oriosvaldo Moura ${ }^{7}$

Os cursos de licenciatura existem no Brasil desde a década de 1930, com a regulamentação das faculdades de Educação, Filosofia, Ciências e Letras, mas foi só com a promulgação da primeira Lei de Diretrizes e Bases - LDB (lei 5.692/1971), que o curso de nível superior passou a ser requisito obrigatório para a atuação como professor das disciplinas específicas do currículo, entre elas a matemática, no então chamado ensino de $1^{\circ}$ grau. $O$ art. 30 daquela lei determinava que a formação específica de $2^{\circ}$ grau (obtida nos cursos normais, conhecidos como "magistério") seria suficiente para atuação como professor apenas nas quatro primeiras séries do $1^{\circ} \mathrm{grau}$, que teria duração total de oito anos. Para atuar nas séries finais e no ensino de $2^{\circ} \mathrm{grau}$, o professor, dito "especialista", das disciplinas do currículo deveria comprovar a conclusão de curso superior de licenciatura plena. Essa organização durou, pelo menos, até 1996, quando a atual LDB - Lei 9.394/1996 - determinou em seu art. 62 que "a formação de docentes para atuar na educação básica far-se-á em nível superior, em curso de licenciatura, de graduação plena, em universidades e institutos superiores de educação".

A cultura escolar impregnada nos cursos de licenciatura, no entanto, ainda remetia aos cursos da Faculdade Nacional de Educação, fundada em 1939, que ofereceria o curso de Bacharelado em Pedagogia. Após a conclusão daquele curso os bacharéis poderiam realizar o curso de Didática, com duração de um ano, ao fim do qual obteriam também o diploma de licenciados. Esse modelo (que ficou conhecido como " $3+1$ ", já que os 3 anos de formação no bacharelado eram complementados com mais 1 ano de estudos de didática, para os optantes da formação conjunta) passou a parametrizar a organização da grande maioria dos cursos de licenciatura (GUEDES e FERREIRA, 2002). A partir dessa opção de organização tornou-se recorrente que os bacharéis em matemática (matemáticos) complementassem suas formações com mais um ano de

\footnotetext{
${ }^{7}$ MOURA, M. O. Formação do profissional de educação matemática. Temas e Debates. Blumenau, ano 8 , n. 7, p.16- 26, 1995.
} 
"formação pedagógica" e passassem a atuar como professores licenciados. Essa característica, claro, teve influência na constituição de uma cultura escolar que prioriza aspectos formais da matemática (próxima daquela praticada por cientistas), em desfavor da constituição de um saber matemático propriamente escolar. É nesse contexto que, sobretudo após a fundação da Sociedade Brasileira de Educação matemática - SBEM, em 1988, constitui-se um debate sobre o papel do matemático e do professor de matemática - ou melhor, do educador matemático - no âmbito das práticas educativas no país.

Desse modo, consideramos adequado apresentar alguns aspectos gerais acerca da formação que remete à atuação do matemático no ensino dessa disciplina escolar e daquela que remete à formação de professores que ensinarão matemática na educação básica. Elegemos, para tal apresentação, aspectos relacionados às proposições oficiais sobre como devem ocorrer ambas as formações no Brasil, bem como nossa análise sobre o percurso formativo promovido pela instituição em que realizamos a pesquisa. Tratamos também, no estudo dos textos oficiais, de destacar aspectos relacionados ao impacto que estes textos podem promover na compreensão acerca do papel do Problema nas práticas pedagógicas. Passamos, a seguir, a tal discussão.

\subsection{A formação do matemático e a formação do professor de matemática}

$\mathrm{Na}$ perspectiva histórico-cultural e da teoria da atividade, pressupõe-se que o estudante deva estar em atividade de estudo e que o professor deva estar em atividade de ensino, como mostraremos no capítulo 2. Isso porque partimos da premissa de que 0 objeto da atividade docente seja, primordialmente, a aprendizagem do aluno. Todavia, as práticas que temos percebido nos cursos que se dedicam à formação de professores de matemática voltam suas ênfases, quase que exclusivamente, para os processos de apropriação da própria matemática (como um fim, em si mesma), em detrimento do ensino e da aprendizagem da docência.

Diante dessa contradição, em debates diversos, geralmente, os contraargumentos indicam a impossibilidade de se ensinar o que não se sabe, de modo a tentar justificar a ênfase atribuída ao ensino de uma matemática pura e distante das necessidades da Educação Básica, nos cursos de formação de professores. Sacristán 
(1991) define como profissionalidade tudo aquilo que é específico das práticas docentes, ou seja, o conjunto de comportamentos, habilidades, atitudes e valores que constituem a especificidade de ser professor. Essa ideia de profissionalidade ratifica o entendimento de que o ensino escolar é uma prática social, por se concretizar na interação entre professores e alunos e por refletirem a cultura e os contextos sociais a que pertencem esses atores. A intervenção do professor é mediada pela sua forma de pensar e de agir diariamente, ao mesmo tempo em que a receptividade do aluno em relação a tal intervenção também depende de sua forma de pensar e agir diariamente. Dessa forma, a profissionalidade supera a mera reprodução de práticas modelares que buscam transmitir, linearmente, técnicas algorítmicas ou soluções modelares a serem aplicadas diretamente, o que sugere que a ênfase na aprendizagem dos conceitos matemáticos compromete a formação adequada dos professores, já que minimiza os demais aspectos dessa prática social referida por Sacristán.

Sacristán (1991) também entende que, como a função dos professores possui essa perspectiva social, ela é determinada pelas necessidades sociais para as quais espera-se que a educação escolar seja a resposta. Ele destaca que o debate social sobre a educação constrói diferentes exigências em relação às funções do professor, que se percebem no conflito entre as expectativas da família e as ações dos professores. $O$ autor entende, ainda, que os professores, de maneira geral e distintamente de outras profissões clássicas, não dominam a prática e o conhecimento especializado relacionado à sua função profissional, como aspectos da organização do ensino, de didáticas e metodologias, mas apenas o conhecimento de conteúdo específico necessário a essa prática.

De fato, notamos que as organizações curriculares dos cursos de licenciatura em matemática, de modo geral, priorizam a abordagem do conteúdo matemático, conforme, por exemplo, Gatti (2009), Gatti e Nunes (2010), Fiorentini e Crecci (2015), Lopes et al. (2015), em prejuízo da apropriação do conhecimento teórico acerca da própria profissão docente, da organização didática e metodológica, fundamentais para a formação do futuro professor.

Ainda de acordo com Sacristán (1991), o conflito entre as expectativas sociais e as práticas dos professores são preponderantes para uma indefinição da real função do 
professor. Há exigências profissionais que superam os aspectos dos processos de ensino, aprendizagem e a ação didática, geralmente entendidos como "limite" da prática docente, e abrangem aspectos menos evidentes, como cuidados com a infância, de higiene, de saúde, de administração escolar, de convivência social e de trabalho, tudo isso em diversos contextos sociais, econômicos e culturais. Complementarmente, se reconhecermos como atividade humana todas as práticas dotadas de intencionalidade e consciência, para que essas "outras dimensões" da prática pedagógica, referidas por Sacristán, possam ser apropriadas pelos professores faz-se necessária uma formação específica que possibilite essa intencionalidade e tomada de consciência.

O esquema apresentado por Sacristán (1991, p. 69) é bastante representativo de seu entendimento sobre as relações envolvidas no sistema de práticas educativas:

Figura 1: Relações do Sistema de Práticas Educativas

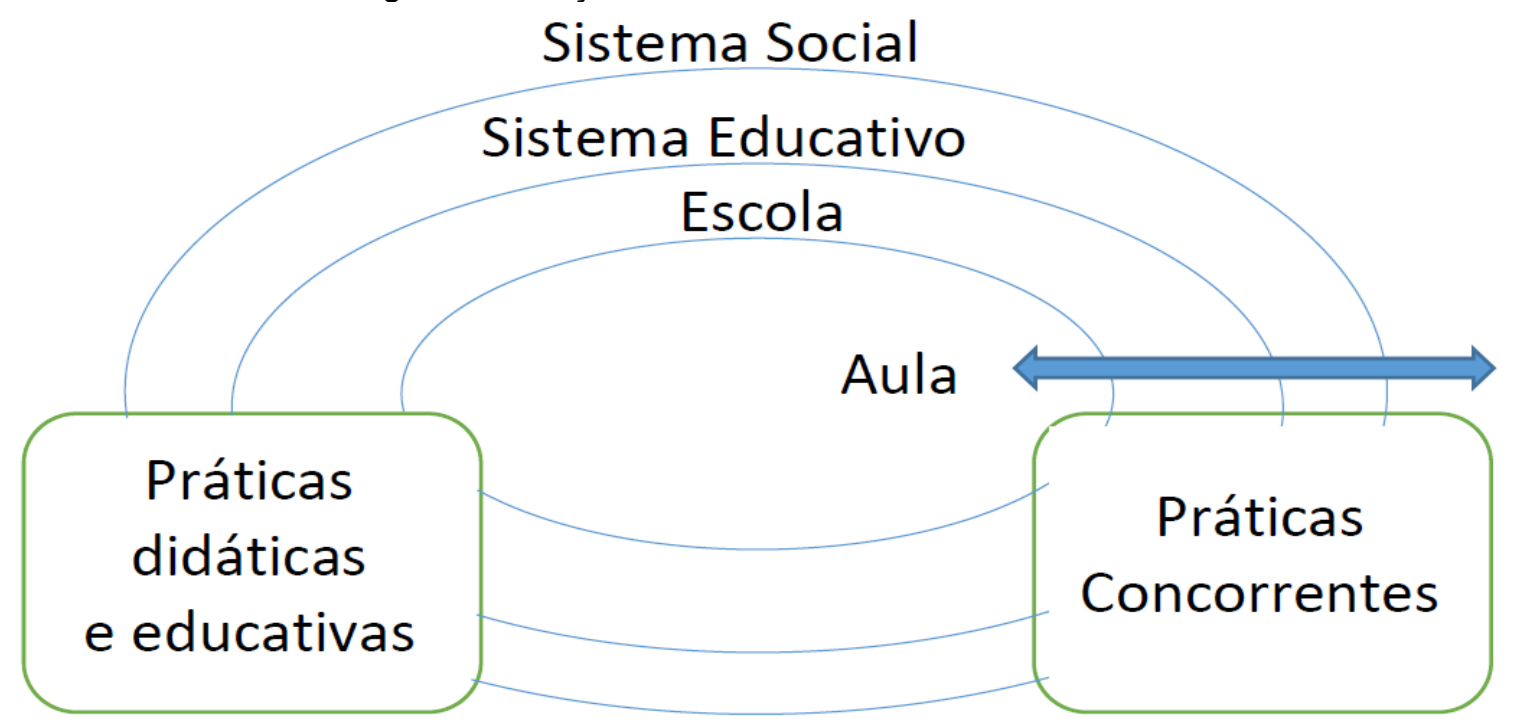

Fonte: SACRISTÁN, 1991, p. 69

A ideia central do autor é a existência de "práticas didáticas e educativas" que se dão no interior das salas de aula, mas em coexistência com práticas relacionadas ao funcionamento do sistema educativo, práticas relacionadas, especificamente, à organização das escolas, além de práticas alheias ao sistema educativo, que ele denomina como "práticas concorrentes". Sacristán (1991) entende que a visão tradicional do ensino foca no "saber-fazer" dos professores e pressupõe uma "acumulação de experiência" que fundamentaria a prática profissional. Essa ideia vai ao encontro do entendimento de que as práticas de formação de professores têm priorizado uma 
formação técnica que aplica rigorosamente regras técnico-científicas que, por sua vez, ainda que remetam a possíveis aplicações pragmáticas cotidianas, não ensejam uma formação voltada ao processo de apropriação da produção humana.

Por tratar-se de um modelo no qual as atividades são entendidas como aplicações rigorosas do conhecimento científico, decorre que, nos cursos de formação, a prática é deixada para o final do curso, quando se supõe que o futuro professor já tenha adquirido todos os conhecimentos necessários para aplicar em sala de aula (RIBEIRO, 1999, p. 30)

De fato, verificamos que práticas formativas voltadas à profissionalidade, como o Estágio Supervisionado, por exemplo, são realizadas apenas na metade final do curso, sobrepostas a outras práticas, quando se entende que a formação do licenciando encaminha-se para a "conclusão" e que ele já "domina" o conteúdo matemático que deverá ser reproduzido em sala de aula. Assim, verificamos uma tendência, no caso das licenciaturas em matemática, de formar matemáticos para atuarem como professores, em detrimento da formação do educador matemático para exercer tal função, conforme indicam, por exemplo, Pimenta e Lima (2005, p. 6) quando afirmam que "na verdade, os currículos de formação têm se constituído em um aglomerado de disciplinas, isoladas entre si, sem qualquer explicitação de seus nexos com a realidade que thes deu origem" e Gama e Souza (2015) quando tratam da superação de uma formação "3+1", em que os cursos formavam bacharéis em 3 anos e as faculdades de educação ofereciam mais 1 ano de formação pedagógica para a obtenção do grau de licenciado - como complemento da formação de bacharel.

Essa perspectiva de formação privilegia, como indicou Sacristán (1991), o saberfazer. Esse saber-fazer remete ao lema "aprender a fazer" que integrou o documento da UNESCO que ficou conhecido como "os quatro pilares da educação" (DELORS, 1996). Outro dos lemas presentes naquele documento defendia a necessidade de "aprender a aprender". Este lema, de acordo com Duarte (2011), subsidiaria interpretações da obra de Vygotsky que buscariam legitimar uma suposta relação entre as proposições do autor russo esse lema "aprender a aprender". Duarte (2011) defende a tese de que tal tentativa de incorporação da teoria de Vygotsky ao universo neoliberal e pós-moderno teria o propósito de "manutenção da hegemonia burguesa no campo educacional" (DUARTE, 2011, p. 1) e seria, portanto, inconsistente com a necessária interpretação marxista que 
fundamenta aquela teoria. Segundo o documento da UNESCO, aprender a aprender "visa não tanto a aquisição de um repertório de saberes codificados, mas antes o domínio dos próprios instrumentos do conhecimento pode ser considerado, simultaneamente, como um meio e como uma finalidade da vida humana" (DELORS, 1996, p. 90). Para Duarte (2011) autores que buscam uma identidade entre esse lema e o desenvolvimento do psiquismo humano, na perspectiva vygotskiana, encontram suporte "na predominância de concepções naturalizantes do ser humano no campo da psicologia educacional" (DUARTE, 2011, p. 29), ou seja, encontram fundamentação em ideias que vão de encontro àquelas propostas por Vygotsky, já que este último compreende, a exemplo de Karl Marx, que o que humaniza o homem é o trabalho, de modo a defini-lo como um ser social, e não como exclusivamente biológico.

A crítica não remete à importância da necessidade de aprender a aprender. De fato, o processo de aprendizagem pressupõe o desenvolvimento de uma autonomia em que se aprenda as diversas formas de se aprender. A crítica de Duarte (2011) remete às concepções que buscam relacionar os estudos de Vygotsky a uma suposta compreensão de que os processos de aprendizagem seriam naturais, de modo que aprender como as pessoas aprendem poderia produzir meios para se ensinar a todas as pessoas da mesma maneira.

Analogamente, entendemos que o "aprender a fazer", da maneira como é compreendido nessa perspectiva neoliberal criticada por Duarte (2011), contrapõe as ideias da teoria histórico-cultural de Vygotsky, já que, nesta última, o "aprender a aprender" e o "aprender a fazer" não constituem fins em si mesmos. Ainda que a ideia apresentada no documento seja um aspecto relevante do processo educacional, ao afirmar que o "aprender a fazer" é indissociável do "aprender a aprender" e, em conjunto, visam "ensinar o aluno a pôr em prática os seus conhecimentos e, também, como adaptar a educação ao trabalho futuro quando não se pode prever qual será a sua evolução" (DELORS, 1996, p. 93), da perspectiva que adotamos, o "aprender a fazer", assim como o "aprender a aprender", são consequências do movimento de apropriação do conhecimento, que é, por sua vez, histórico e social.

Em outras palavras, entendemos que o estudante, seja durante a educação básica ou na formação de professores, não aprende a aprender ou a fazer simplesmente por 
observar um colega mais experiente (como o professor, por exemplo) fazendo algo, como se essa aprendizagem ocorresse sempre da mesma maneira, naturalmente, segundo algum suposto estágio de maturação biológica. Superando essa ideia, compreendemos que o aprender a aprender e o aprender a fazer são necessidades humanas, a partir das quais os sujeitos se motivam para buscarem um objeto que possa satisfazer essas necessidades de aprender e de fazer e, consequentemente, possam se desenvolver. Nesse sentido, não podemos ensinar a fazer simplesmente fazendo modelos a serem seguidos e não aprendemos a fazer reproduzindo ações realizadas previamente por outros. Aprendemos a aprender e a fazer a partir das necessidades pessoais de que algo seja aprendido ou seja feito e dos meios para que se possa aprender como fazer, sendo certo que tais meios são históricos e sociais.

Contudo, cabe questionar em que medida, as diferentes opções de organização curricular - que priorizam a formação técnica direcionada à aplicabilidade, sensorial e modelar, para exercer as funções docentes - estão ou não de acordo, com o que, socialmente, no Brasil, se espera da atuação profissional do professor. Essa expectativa social é refletida, por exemplo, nos textos oficiais e parametrizadores de currículos e de formações. É nesse contexto que buscamos, a seguir, compreender um pouco melhor as propostas oficiais para a formação de professores de matemática nos cursos de licenciatura.

\subsection{Textos oficiais que impactam na formação de professores de matemática e o papel do Problema nestes textos}

Buscamos nos documentos oficiais indicações de como devem estar estruturados os cursos que se propõem a formar professores, de maneira geral, e professores de matemática, de forma específica. O primeiro documento que apresentamos é a resolução $\mathrm{n}^{\circ}$ 2, de 1 de julho de 2015, que define as Diretrizes Curriculares Nacionais - DCN para a formação inicial em nível superior (cursos de licenciatura, cursos de formação pedagógica para graduados e cursos de segunda licenciatura) e para a formação inicial e continuada de professores.

O documento é uma publicação oficial do Conselho Nacional de Educação, órgão deliberativo, normativo e consultivo do Ministério da Educação, e possui força de lei. Em 
sua introdução, para estabelecer as diretrizes curriculares comuns aos cursos de licenciatura, considera-se

[...] a docência como ação educativa e como processo pedagógico intencional e metódico, envolvendo conhecimentos específicos, interdisciplinares e pedagógicos, conceitos, princípios e objetivos da formação que se desenvolvem entre conhecimentos científicos e culturais, nos valores éticos, políticos e estéticos inerentes ao ensinar e aprender, na socialização e construção de conhecimentos, no diálogo constante entre diferentes visões de mundo (BRASIL, 2015, p. 2, grifos nossos).

Nesse sentido o texto institui que, para o exercício da docência é imprescindível o domínio de conteúdos e metodologias (BRASIL, 2015). A particularidade de que o estudante em processo de formação para a docência aprende em um ambiente muito similar àquele em que atuará profissionalmente, talvez seja fator determinante para o entendimento superficial de que a abordagem metodológica que o licenciando adotará quando for professor é uma "consequência natural" do domínio do conceito, já que há uma proposta metodológica impregnada na prática do professor que ensina na licenciatura. Com isso, parece ter se cristalizado uma organização formativa em que o professor ensina o "o quê" e o "como" fica por conta da observação do licenciando das práticas adotadas pelo formador. Não parece, no entanto, ser essa a indicação dos referenciais de diretrizes curriculares.

Entendemos que, da mesma maneira como não se espera que, durante o processo de formação, o conhecimento sobre o conteúdo matemático emerja naturalmente na consciência do estudante, partindo de "lugar nenhum" ou da observação das ações do sujeito que domina tal conteúdo, não se pode esperar que os conhecimentos relativos às práticas pedagógicas, às diferentes opções didáticas e metodológicas, aos diversos materiais didáticos, ou à capacidade de formular ou resolver Problemas "apareçam" naturalmente na consciência do futuro professor, para serem utilizados quando se fizerem necessários. Em outras palavras, da mesma maneira que se ensina ao licenciando a derivar ou a integrar nas aulas de Cálculo Diferencial e Integral, é necessário ensiná-lo, em momentos específicos e intencionalmente organizados para esse fim, a formular Problemas, a resolver Problemas, a selecionar ou construir materiais didáticos, a organizar sua atividade de ensino ou qualquer outra atividade que esteja no âmbito da profissionalidade. 
Especificamente, passaremos a apresentar as propostas contidas nas Diretrizes Curriculares Nacionais, nos Parâmetros Curriculares Nacionais e na Base Nacional Comum Curricular, por serem os documentos de maior evidência acerca do que é de como devem ser aprendidos os conteúdos curriculares no país. A opção por estes documentos, apresentada a seguir, não deve ser compreendida por uma perspectiva linear ou cronológica. Tratamos das diretrizes acerca da formação de professores, especialmente nas licenciaturas em matemática e buscamos, em seguida, compreender indicações acerca do papel do Problema nas práticas pedagógicas, de acordo com documentos como os $\mathrm{PCN}$ e a BNCC, entendendo que estes, ainda que não sejam documentos especificamente voltados à formação de professore, têm grande impacto nesta. Posteriormente, tratamos de apresentar, para efeitos de comparação, a organização curricular à qual os licenciandos que participaram de nosso estudo estiveram vinculados.

\subsubsection{Diretrizes Curriculares Nacionais}

As Diretrizes Curriculares Nacionais - DCN para formação de professores da Educação Básica instituem "princípios, fundamentos, dinâmica formativa e procedimentos a serem observados nas políticas, na gestão e nos programas e cursos de formação, bem como no planejamento, nos processos de avaliação e de regulação das instituições de educação que as ofertam" (BRASIL, 2015, p. 2). Os aspectos indicados nas resoluções têm força de lei e devem ser atendidos por todos os cursos voltados à formação de professores no país. Para os cursos de matemática têm especial destaque as resoluções $n^{\circ} 2$, de $1^{\circ}$ de julho de 2015 e o parecer $n^{\circ} 1.302 / 2001$, que tratam, respectivamente, das diretrizes gerais a serem respeitadas por todos os cursos de formação de professores e das diretrizes para os cursos de matemática, tanto bacharelados quanto licenciaturas.

De modo geral, a resolução $n^{\circ} 2 / 2015$ compreende

[...] a docência como ação educativa e como processo pedagógico intencional e metódico, envolvendo conhecimentos específicos, interdisciplinares e pedagógicos, conceitos, princípios e objetivos da formação que se desenvolvem na construção e apropriação dos valores éticos, linguísticos, estéticos e políticos do conhecimento inerentes à sólida formação científica e cultural do ensinar/aprender, à socialização e construção de conhecimentos e sua inovação, em diálogo constante entre diferentes visões de mundo. No exercício da 
docência, a ação do profissional do magistério da educação básica é permeada por dimensões técnicas, políticas, éticas e estéticas por meio de sólida formação, envolvendo o domínio e manejo de conteúdos e metodologias, diversas linguagens, tecnologias e inovações, contribuindo para ampliar a visão e a atuação desse profissional (BRASIL, 2015, p. 3, grifos nossos).

De modo a caracterizar os princípios da formação do profissional que atuará na docência, a resolução defende o caráter indissociável entre aspectos teóricos e práticos. Essa indicação pode ser interpretada como a indissociabilidade entre o conteúdo matemático aprendido na formação, que seria a teoria, e os métodos adotados para que se ensine tais conteúdos, que constituiriam a prática. Essa interpretação fica evidente, por exemplo, quando o documento explicita como uma das aptidões do egresso da licenciatura a necessidade de "dominar os conteúdos específicos e pedagógicos e as abordagens teórico-metodológicas do seu ensino, de forma interdisciplinar e adequada às diferentes fases do desenvolvimento humano" (BRASIL, 2015, p. 8).

Em outras palavras, entendemos ser uma indicação oficial que os cursos de formação, inicial ou continuada, de professores promovam uma "organização complexa na função de promover a educação para e na cidadania" (BRASIL, 2015, p. 7). Então, o professor ensina o que ensina para que o seu aluno possa, entre outras coisas, exercer a cidadania e, no nosso caso, o instrumento utilizado para isso é a matemática, de maneira análoga a qualquer outro componente disciplinar previsto para ser ensinado durante a educação básica. Essa interpretação coloca o disposto na resolução em oposição à compreensão de que, no caso da pretensão de formação do professor de matemática, a formação de matemáticos seja suficiente para que se alcancem os objetivos de um projeto educacional que possa preparar para o exercício da cidadania, ainda que, reconhecidamente, o conhecimento dos conteúdos matemáticos seja indispensável para que se alcance tal meta.

Da mesma maneira, o parecer $n^{\circ} 1.302 / 2001$, que apresenta as diretrizes específicas para a formação em matemática, já de início, indica uma importante distinção entre a formação do bacharel em matemática e do licenciado em matemática, que entendemos ser uma delimitação de atuação de cada profissional: "os cursos de Bacharelado em matemática existem para preparar profissionais para a carreira de ensino superior e pesquisa, enquanto os cursos de Licenciatura em matemática tem 
como objetivo principal a formação de professores para a educação básica" (BRASIL, 2001, p. 1).

Ainda de acordo com o parecer, um curso de bacharelado em matemática deve promover "uma sólida formação de conteúdos de matemática" e "uma formação que lhes prepare para enfrentar os desafios das rápidas transformações da sociedade, do mercado de trabalho e das condições de exercício profissional" (BRASIL, 2001, p. 3). E, sem excluir essas habilidades da formação do licenciado, o documento destaca a importância complementar de que este possua também uma "visão de seu papel social de educador e capacidade de se inserir em diversas realidades com sensibilidade para interpretar as ações dos educandos", "visão da contribuição que a aprendizagem da matemática pode oferecer à formação dos indivíduos para o exercício de sua cidadania" e "visão de que o conhecimento matemático pode e deve ser acessível a todos, e consciência de seu papel na superação dos preconceitos, traduzidos pela angústia, inércia ou rejeição, que muitas vezes ainda estão presentes no ensino-aprendizagem da disciplina" (BRASIL, 2001, p. 3).

Destacamos a ênfase da diretriz na caracterização do licenciado em matemática como aquele que, além do domínio do conhecimento matemático referente a sua atuação profissional, deve receber uma formação especificamente voltada ao desenvolvimento de habilidades como, por exemplo, "desenvolver estratégias de ensino que favoreçam a criatividade, a autonomia e a flexibilidade do pensamento matemático dos educandos, buscando trabalhar com mais ênfase nos conceitos do que nas técnicas, fórmulas e algoritmos" (BRASIL, 2001, p. 4). A indicação sobre a necessidade de maior ênfase nos conceitos do que nas técnicas, fórmulas e algoritmos representa uma oposição basilar às práticas tradicionais que adotam o roteiro que parte de uma definição e passa a resolução de modelos e proposição de exercícios. Esse roteiro se verifica na replicação inadvertida e recorrente de técnicas e algoritmos que remetem a uma matemática já "descoberta" por outros e que precisaria ser transmitida aos aprendizes. Esta perspectiva, geralmente, não considera as particularidades do processo educativo, como o aluno, a escola, a cultura e a história.

Em relação aos conteúdos que devem ser ministrados, as diretrizes explicitam também as distinções entre a formação do bacharel e do licenciado. Para a formação do 
bacharel são exigidos estudos de Cálculo Diferencial e Integral, Álgebra Linear, Topologia, Análise matemática, Álgebra, Análise Complexa, Geometria Diferencial, Probabilidade e Estatística, além de Física como campo de aplicação dos estudos matemáticos. Já para os licenciandos, os estudos devem permear o Cálculo Diferencial e Integral e a Álgebra Linear, como elementos estruturantes da matemática a ser ensinada na educação básica, Fundamentos de Análise, Fundamentos de Álgebra, Fundamentos de Geometria e Geometria Analítica. Inferimos que ao adotar o termo "fundamentos" o texto pretende um distanciamento dos aspectos que envolvem esses temas aplicados no mundo científico, aproximando de uma interpretação destes como conhecimentos necessários ao exercício da cidadania. A matemática a ser aprendida pelo professor não é, no entanto, "superficial" ou "mais fácil" do que aquela aprendida pelo bacharel, como se poderia supor, erroneamente, a partir do termo "fundamentos". Ela deve, ao contrário, ser tão robusta quanto possa ser para subsidiar que se constitua como alicerce (daí ser fundamento) de uma prática educativa humanizadora, capaz de satisfazer as necessidades dos sujeitos.

O documento complementa o conjunto de conteúdos explicitando a necessidade de estudos voltados aos "conteúdos matemáticos presentes na educação básica nas áreas de Álgebra, Geometria e Análise", "conteúdos de áreas afins à matemática, que são fontes originadoras de problemas e campos de aplicação de suas teorias" e "conteúdos da Ciência da Educação, da História e Filosofia das Ciências e da matemática" (BRASIL, 2001, p. 6).

Destacamos, também, a indicação explicita da necessidade de incluir nos cursos de licenciatura os estudos de História da Matemática, o que nos permite inferir o reconhecimento destes como fundamentais para a aprendizagem da docência e da organização do ensino.

Sendo as diretrizes curriculares documentos com força de lei e de observação obrigatória, verificamos a clara distinção entre o que é instituído para a formação do matemático e aquilo que se apresenta como parâmetro para a formação do educador matemático. Apesar disso, culturalmente, a carreira docente ainda não se consolidou como detentora de uma especificidade profissional própria, sendo ainda muito comum que profissionais de outras áreas, ou mesmo leigos, exerçam a docência como fonte de 
rendimentos extras ou mesmo para atender a demandas emergenciais de falta de professores nas diversas redes. Com isso, é corriqueiro encontrar nas salas de aula, como responsáveis pelas matérias do currículo, estudantes de licenciaturas e bacharéis, mesmo de outras áreas do conhecimento, em que a matemática é apenas recurso de aplicação. Tal demanda é tão premente que o Conselho Nacional de Educação, órgão consultivo e deliberativo ligado ao Ministério da Educação - MEC e responsável pela edição das diretrizes aqui apresentadas, fez publicar em 1997 a resolução $n^{\circ}$ 2, que dispõe sobre os programas especiais de formação pedagógica de docentes para as disciplinas do currículo do ensino fundamental, do ensino médio e da educação profissional em nível médio. Essa resolução, cujo regulamento foi incorporado posteriormente pela resolução $n^{\circ} 2 / 2015$, na prática, permite uma continuidade do sistema " $3+1$ ", que já citamos anteriormente, em que outros profissionais com cursos superiores em áreas consideradas "afins", podem realizar cursos "complementares" de cerca de 1 ano de duração, e atuar como licenciados na educação básica.

Esta resolução $n^{\circ} 2 / 97$, previa que a formação complementar devesse compreender, no mínimo, 540 horas (aumentada para 1.000 horas após a resolução 2/2015), das quais 300 destinavam-se à parte prática que se resumiam à realização de estágio curricular supervisionado. No contexto dessa resolução, além dos próprios bacharéis em matemática, poderiam complementar a formação, para obter o título de licenciados, os engenheiros, administradores de empresas, estatísticos, tecnólogos em áreas técnicas, entre outros. Tais áreas, inegavelmente, têm a matemática como um recurso de aplicação imprescindível ao exercício, porém, não necessariamente integrado às necessidades metodológicas, conceituais e didáticas que seriam inerentes ao projeto educacional nacional presente nas demais diretrizes.

Em outras palavras e em suma, ao mesmo tempo em que, nas diretrizes curriculares nacionais, podemos reconhecer a importância de uma formação específica do educador matemático, distinguindo-o do bacharel em matemática para superar a ênfase no ensino de técnicas e algoritmos, uma demanda não suprida por professores criou uma espécie flexibilização que passou a admitir a atuação na docência de profissionais cuja formação seria técnica e complementada por estudos de caráter 
pedagógico, potencializando uma tendência, contraditória, ao ensino de técnicas, fórmulas e algoritmos.

\subsubsection{Parâmetros Curriculares Nacionais}

Diferentemente das DCN apresentadas na seção anterior, os Parâmetros Curriculares Nacionais - PCN não são documentos dirigidos especificamente a aspectos da formação de professores das diversas disciplinas. Ao contrário, como o próprio nome sugere, os PCN configuram aspectos norteadores dos currículos a serem adotados pelos sistemas de ensino. Como parâmetros para os currículos, os textos oficiais têm caráter norteador e não normativo, de modo que seu conteúdo reflete uma proposta curricular coerente com um projeto pedagógico nacional que visa promover uma educação que tem como um de seus objetivos o exercício da cidadania.

Os PCN de matemática alertam sobre a necessidade de o professor "ter clareza de suas próprias concepções sobre a matemática, uma vez que a prática em sala de aula, as escolhas pedagógicas, a definição de objetivos e conteúdos de ensino e as formas de avaliação estão intimamente ligadas a essas concepções" (BRASIL, 1998, p. 36).

\footnotetext{
Numa perspectiva de trabalho em que se considere o aluno como protagonista da construção de sua aprendizagem, o papel do professor ganha novas dimensões. Uma faceta desse papel é a de organizador da aprendizagem; para desempenhá-la, além de conhecer as condições socioculturais, expectativas e competência cognitiva dos alunos, precisará escolher os problemas que possibilitam a construção de conceitos e procedimentos e alimentar os processos de resolução que surgirem, sempre tendo em vista os objetivos a que se propõe atingir (BRASIL, 1998, p. 38).
}

Entendemos que a ideia de "escolher os Problemas" pode remeter à ideia, defendida por alguns pesquisadores, de que para cada conceito matemático a ser aprendido pelo aluno, exista um Problema em cuja solução será aplicado tal conceito. Esse seria o caso, por exemplo, da Teoria das Situações Didáticas (BROUSSEAU, 2008). Geralmente, os Problemas presentes em livros didáticos e apostilas utilizadas pelos professores são elaborados por outros e visam aplicar diretamente técnicas, definições ou algoritmos já ensinados anteriormente. Nós, contudo, compreendemos ser necessário superar essa ideia estrita de "escolha", fazendo incluir a elaboração, reelaboração, adaptação de Problemas que possam ser apresentados aos alunos no contexto de 
situações nas quais as necessidades de aprender e de fazer sejam suscitadas, de modo a estarem a serviço de seus objetivos de ensino e tenham papel definido na organização do ensino. Esta compreensão atribui ao Problema um papel importante na organização do ensino. Os professores devem ser capazes de reconhecer no Problema aspectos do movimento histórico e cultural que levou a humanidade a desenvolver um conceito, ou seja, o Problema deve ser desencadeador de necessidades de apropriação de um conhecimento que foi constituído historicamente.

Os próprios PCN indicam que "tradicionalmente, os problemas não têm desempenhado seu verdadeiro papel no ensino, pois, na melhor das hipóteses, são utilizados apenas como forma de aplicação de conhecimentos adquiridos anteriormente pelos alunos" (BRASIL, 1998, p. 39). Essa "tradição" parece ter relação com a concepção, já referida, de que seria natural que a capacidade de resolver Problemas decorra da apresentação prévia do conteúdo matemático, e também do fato de os Problemas apresentados nos livros didáticos, de modo geral, serem meras aplicações de conteúdos já apresentados nestes recursos.

O Problema formulado pelo autor de um livro didático, por exemplo, remete a objetivos específicos do conteúdo em estudo e, geralmente, são mesmo aplicações das definições ou propriedades matemáticas apresentadas anteriormente. Obviamente, esse tipo de Problema tem méritos e encontra seu papel nas práticas de ensino, mas, normalmente, remetem ao domínio de um algoritmo ou à recordação de uma propriedade específica, ou seja, não garantem que o estudante tenha necessidade de apropriar-se dos conceitos envolvidos na solução, mas apenas exercitam a capacidade de classificação dos Problemas, segundo aspectos a serem aplicados na solução, e a memorização de procedimentos. Em outras palavras, enfatizam o "saber fazer" em detrimento de um necessário "saber porque se faz".

Mais uma vez, podemos compreender que o texto oficial remete a uma necessária especificidade na formação do educador matemático, que pressupõe a matemática como recurso e instrumento de formação do cidadão e não como um fim em si mesma, já que o texto indica que o verdadeiro papel do Problema não se resumiria à aplicação de conteúdos já apresentados (como seria, por exemplo, numa formação estritamente 
técnica), mas sim um instrumento importante para se alcançar os objetivos de aprendizagem que se pretende atingir.

Os PCN de matemática, antes mesmo de apresentarem os parâmetros específicos referentes ao ensino dessa disciplina, retomam objetivos gerais de formação no Ensino Fundamental, sendo o primeiro deles o seguinte: "compreender a cidadania como participação social e política, assim como exercício de direitos e deveres políticos, civis e sociais, adotando, no dia-a-dia, atitudes de solidariedade, cooperação e repúdio às injustiças, respeitando o outro e exigindo para si o mesmo respeito" (BRASIL, 1998, p. 6). Dessa forma, o documento ratifica o papel do professor como formador para o exercício da cidadania, de modo que caberia ao professor de matemática a especificidade de lançar mão dos conhecimentos produzidos nessa área para promover a formação de seu aluno tendo tal exercício como meta.

Assim, considerando o professor como "colega mais capaz", em referência à ideia apresentada por Vygotsky (2001), e como organizador da atividade de ensino sendo, portanto, conhecedor consciente do motivo e objeto da mesma, faz-se necessário reconhecer a importância de que os professores desenvolvam a capacidade de elaborar ou adaptar os Problemas, de modo que estes sirvam aos seus objetivos de ensino e para a aprendizagem dos alunos.

Já para o Ensino Médio, o projeto de organização curricular por áreas do conhecimento aproxima a matemática das ciências da natureza e apresenta um documento único com tal propósito interdisciplinar. O texto afirma ter o objetivo de "trazer elementos de utilidade para o professor de cada disciplina, na definição de conteúdos e na adoção de opções metodológicas" (BRASIL, 2000, p. 12).

Cada disciplina ou área de saber abrange um conjunto de conhecimentos que
não se restringem a tópicos disciplinares ou a competências gerais ou
habilidades, mas constituem-se em sínteses de ambas as intenções formativas.
Ao se apresentarem dessa forma, esses temas estruturadores do ensino
disciplinar e seu aprendizado não mais se restringem, de fato, ao que
tradicionalmente se atribui como responsabilidade de uma única disciplina.
Incorporam metas educacionais comuns às várias disciplinas da área e das
demais e, também por isso, tais modificações de conteúdo implicam modificações
em procedimentos e métodos, que já sinalizam na direção de uma nova atitude
da escola e do professor. (BRASIL, 2000, p. 13)

Podemos interpretar que a indicação da proposta curricular não se limita à apresentação de conteúdos isolados entre si em uma sequência lógica de "pré- 
requisitos". O parâmetro que indica ser necessária a superação da mera apresentação de "tópicos disciplinares ou competências gerais ou habilidades" sugere a necessidade de que o professor domine aspectos da prática pedagógica que permitam organizar o ensino de modo a evidenciar aspectos que levem em consideração o porquê de os estudantes precisarem aprender os conceitos em estudo em um contexto geral de preparação para o trabalho e o exercício da cidadania.

Sob tal perspectiva, o aprendizado é conduzido de forma que os saberes disciplinares, com suas nomenclaturas específicas, não se separam do domínio das linguagens de utilidade mais geral, assim como os saberes práticos, como equacionar e resolver problemas reais, não se apartam de aspectos gerais e abstratos, de valores éticos e estéticos, ou seja, estão também associados a visões de mundo. Nessa proposta, portanto, competências e conhecimentos são desenvolvidos em conjunto e se reforçam reciprocamente. (BRASIL, 2000, p. 13)

Esse caráter de formação geral que supere a apresentação de uma lista de conteúdos que constitua um "currículo mínimo" vai de encontro a uma proposta formativa de professores que, por sua vez, elenque um conjunto de disciplinas com propósito quase exclusivo de se ensinar conceitos de uma matemática pura ou aplicada, mas isolada do debate sobre a forma como ele articula-se com o conteúdo a ser ensinado na educação básica. Ao contrário, pressupõe uma formação de um profissional que domine tanto aspectos específicos dos conceitos que deve ensinar quanto aspectos gerais de formação que envolvam métodos e recursos que permitam articular os conhecimentos específicos e os gerais visando uma formação humanizadora.

Os PCN (BRASIL, 2000, p. 15) indicam como uma competência para o Ensino Médio "contextualizar social ou historicamente os conhecimentos" de modo que, podemos entender mais uma vez, a proposta é a de que o professor não apenas apresente uma definição e a resolução modelar de alguns exercícios a ser reproduzida posteriormente pelos estudantes. Mais do que isso, verificamos a clara indicação de que, como um dos propósitos da educação básica, no Ensino Médio, o professor deve formar seu aluno para compreender quais necessidades humanas, histórica e culturalmente, o conhecimento produzido veio a satisfazer. Essa interpretação ganha especial importância quando verifica-se nela uma proposta de superação do que poderíamos chamar de "pragmatismo no ensino", que seria a ideia deweyana ${ }^{8}$ segundo a qual só encontrariam

${ }^{8}$ Em referência a John Dewey. John Dewey foi um filósofo e pedagogo norte-americano, tendo sido um 
lugar no currículo escolar aqueles conceitos que tivessem aplicação imediata na vida cotidiana dos alunos. Dessa forma, o propósito de compreender os conceitos em estudo histórica e culturalmente, engloba também a possibilidade de aplicação imediata, mas a supera. Permitimo-nos aqui um pequeno exemplo ilustrativo dessa superação:

Seria razoável, a partir de uma apropriação superficial (e, provavelmente, anacrônica) das proposições de pensadores contemporâneos e discípulos de John Dewey, como Edward Lee Thorndike, que escreveu manuais voltados especificamente para o ensino de matemática (VIRGENS, 2014), que o ensino do conceito de Fração não fosse objeto do currículo a ser estudado na educação básica brasileira, já que no país, geralmente, não utilizamos cotidianamente a representação fracionária dos números racionais, sobretudo em comparação com os países de língua inglesa. A parte não inteira das unidades de medida é apresentada no Brasil, quase sempre, por meio da representação decimal. Assim, a premissa de que aprender a operar com frações seria secundário para os alunos brasileiros, já que não faz parte do cotidiano dos alunos, seria uma consequência lógica.

Mas, ao contrário, a importância do ensino de Frações no contexto da educação básica, advém não de sua aplicabilidade direta ou não no cotidiano do aluno, ainda que Ihe corresponda também. Mas sim da importância das Frações como resposta humana à necessidade de medir terras nos períodos de cheia do Rio Nilo, que remete à comparação entre grandezas (CARAÇA, 1951). Citando uma proposição do historiador Heródoto, Caraça (1951) indica que

Disseram-me que este rei (Sesóstria) tinha repartido todo o Egipto entre os egípcios, e que tinha dado a cada um uma porção igual e rectangular de terra, com a obrigação de pagar por ano um certo tributo. Que se a porção de algum fosse diminuída pelo rio (Nilo), ele fosse procurar o rei e lhe expusesse o que tinha acontecido à sua terra. Que ao mesmo tempo o rei enviava medidores ao local e fazia a terra, a fim de saber de quanto ela estava diminuída e de só fazer pagar o tributo conforme o que lhe tivesse ficado de terra. Eu creio que foi daí que nasceu a Geometria e que depois passou aos gregos (CARAÇA, 1951, p. 32).

dos principais representantes da corrente pragmatista que propunha, essencialmente, que o conjunto de conteúdos a serem estudados na escola deveriam ter aplicação imediata na vida cotidiana dos alunos, bem como que deveria ser por essas necessidades determinado. 
Entendemos que a necessidade histórica que levou a humanidade a desenvolver o conceito que, atualmente, conhecemos como Fração potencializa uma aprendizagem conceitual que supera a mera observação de relações aritméticas entre parte e todo e a apresentação e aplicação de definições e algoritmos operatórios, permitindo a constituição de um conhecimento teórico que envolve a comparação entre grandezas. Isso porque a aplicabilidade cotidiana do conceito decorre da necessidade humana de que tal conceito exista, e não o contrário, ou seja, o motivo que impulsiona o movimento de apropriação (e o que impulsiona as características do Problema a ser apresentado ao estudante) não precisa ser, necessariamente, a aplicação cotidiana do conceito, mas sim a necessidade que the deu origem.

Quando o PCNEM indica a, já referida, necessidade de que o estudante do Ensino Médio deva "contextualizar social ou historicamente os conhecimentos", também remete a algumas competências a serem avaliadas no Exame Nacional do Ensino Médio ENEM e que seriam atendidas pelo desenvolvimento dessa habilidade como, por exemplo, a avaliação da capacidade de "compreender processos, sejam eles sociais, naturais, culturais ou tecnológicos" ou de "diagnosticar e enfrentar problemas reais" (BRASIL, 2000, p. 15). Verificamos que o que é avaliado no ENEM não se restringe à capacidade de classificar e aplicar definições e algoritmos que resolvam situações de maneira imediata, mas sim a compreensão dos processos como um todo, incluindo aspectos sociais, culturais e históricos que trazem impregnadas em si as necessidades históricas e sociais, além de resolver Problemas "reais". O termo "reais", por sua vez, também vem sendo compreendido como referência à aplicabilidade cotidiana do conceito envolvido na solução, mas, deve também remeter às necessidades humanas que, historicamente, dão origem aos conceitos que são aplicados depois em situações específicas.

A proposta de articulação interdisciplinar apresentada pelo PCNEM elege como tema norteador, para o ensino de ciências da natureza e matemática, a linguagem. Nesse sentido, a título de exemplo, o texto destaca a importância da apropriação dos logaritmos como linguagem que permite o estudo e apropriação de diversas áreas.

A explicitação de linguagens, usadas em comum por diferentes disciplinas científicas, permite ao aluno perceber sua universalidade e também distinguir especificidades desses usos. Um exemplo disso é o uso do logaritmo, operação 
que dá origem a funções matemáticas, mas que também é linguagem de representação em todas as ciências. Ao se ensinar este conceito, operação ou função, o professor de matemática, inicialmente, mostra que dez milhões 10.000.000 - é dez vezes dez, sete vezes seguidas (sic), ou seja, dez à potência 7 , ou seja, $10^{7}$. Uma operação inversa é o logaritmo na base 10 , ou seja, $\log _{10}(10.000 .000)=7$, que, conhecido o número dez milhões, determina qual a potência de 10 que resulta nele (BRASIL, 2000, p.26, grifo nosso).

Verificamos que este aspecto dos logaritmos apresentado como ponto de partida do trabalho do professor, ao indicar que "[...] o professor de matemática, inicialmente, mostra que dez milhões [...]", propõe um caso particular a partir do qual poderia ser apresentada a definição de logaritmo como operação inversa da potenciação. Essa definição poderia, então, ser transposta para a resolução de situações-problema das outras áreas do conhecimento, que envolvessem os logaritmos. Além disso, apesar de ser um exemplo de atuação articulada que propõe a utilização do conceito em estudo como recurso para a interpretação da realidade ao redor do aluno, o texto atribui ao professor de matemática a responsabilidade de "ensinar o conceito" para que ele possa ser aplicado às outras áreas, reforçando a ideia de que o conceito existe previamente como resposta a Problemas das disciplinas que compõem a área, e que a apresentação da definição seria condição necessária e suficiente para a solução de qualquer Problema que envolvesse o conceito, inclusive aqueles pertinentes a outras áreas do conhecimento.

Segundo o PCNEM

Esse aprendizado, no entanto, perderia contexto se não se explicitasse a importância dos logaritmos, em questões tecnológicas e em outras ciências, para expressar grandezas cujo intervalo de variação é exponencial. Por exemplo, o ouvido humano pode ouvir ruídos um trilhão de vezes menores do que o mais intenso a que resiste, no limite da dor. Para conseguir abranger esse imenso intervalo criou-se, a partir da potência sonora, a escala logarítmica de decibéis. Usando essa escala, pode-se situar sons com intensidades variando de 1 a 1 trilhão em um gráfico com só treze divisões, e não um trilhão delas. Também é logarítmica a escala Richter dos abalos sísmicos. Um aluno que compreender o caráter logarítmico dessa escala saberá que um terremoto caracterizado pelo nível 7 não tem uma intensidade só acrescida em 3, relativamente a um abalo de nível 4, mas sim mil vezes esta intensidade, ou seja, multiplicada por $10^{3}$. Usase ainda uma escala logarítmica para definir o pH de substâncias, coeficiente que caracteriza a condição mais ácida ou mais básica de soluções. Também populações de micro-organismos podem variar exponencialmente, tornando a escala logarítmica igualmente conveniente em Biologia. Estas sugestões, que por acaso envolveram funções logarítmicas, poderiam ter envolvido funções trigonométricas, exponenciais ou distribuições estatísticas. Não só o professor de matemática deve estar atento para ilustrar a utilidade dos instrumentos de representação que ensina, mas qualquer professor que estiver fazendo uso, em 
sua disciplina, de uma linguagem matemática já pode defini-la e ensiná-la sem esperar que o professor de matemática seja o primeiro a desenvolver uma linguagem de uso amplo em todas as ciências. (BRASIL, 2000, p.26, grifo nosso)

Como vemos, a aplicabilidade do conceito no exemplo que se apresenta com o intuito de sugerir as interrelações existentes entre as disciplinas da área, destaca seu caráter ilustrativo de eventuais usos cotidianos do conceito em estudo ao invés de promover uma compreensão das necessidades que, histórica e socialmente, levaram a humanidade a desenvolver tal conceito. Esse aspecto, ao contrário da interpretação que apresentamos anteriormente a respeito de outros segmentos do mesmo documento, parece incentivar o caráter pragmático como ponto de vital relevância nas práticas docentes. Essa característica do texto oficial, como não poderia deixar de ser, ecoa nas salas de aula de formação de professores de matemática e verifica-se em um discurso segundo o qual os Problemas só poderiam ser classificados como tal se descrevessem algum contexto emergente de situações cotidianas que remetessem à aplicação do conceito em estudo.

Defendendo que "a matemática deve ser compreendida como uma parcela do conhecimento humano essencial para a formação de todos os jovens, que contribui para a construção de uma visão de mundo, para ler e interpretar a realidade" (BRASIL, 2000, p. 111) os PCNEM apresentam duas situações que, segundo o texto, seriam exemplos de Problemas que poderiam desenvolver as competências e habilidades necessárias à construção dessa visão de mundo. Por se tratar de um documento que propõe um parâmetro norteador das práticas docentes, entendemos que tal indicação tende a ser uma caracterização dos Problemas que, espera-se, os professores utilizem em suas aulas com vistas ao desenvolvimento das, assim chamadas, "competências e habilidades" a serem desenvolvidas, de acordo com a premissa dos PCNEM, pelos estudos de matemática. Por isso trataremos aqui, brevemente, de aspectos desses Problemas:

Figura 2:Exemplos de Problema, segundo os PCNEM 
Lendo os jornais de sua cidade, você encontra o gráfico que mostra a intenção de votos para prefeito, com uma margem de erro de $2 \%$, em diferentes momentos da campanha.

\section{Exemplo 1}

\begin{tabular}{|c|c|c|c|c|c|c|c|}
\hline \multicolumn{8}{|l|}{$50 \%$} \\
\hline $50 \%$ & $41 \%$ & $42 \%$ & $37 \%$ & $38 \%$ & $38 \%$ & & \multirow{6}{*}{$\begin{array}{l}\text { - Souza } \\
\text { - Silveira } \\
\text { ^ Santos }\end{array}$} \\
\hline $30 \%$ & & & & & & $\begin{array}{l}35 \% \\
-34 \%\end{array}$ & \\
\hline $20 \%$ & $28 \%$ & $30 \%$ & $31 \%$ & $32 \%$ & $30 \%$ & $\triangle 23 \%$ & \\
\hline $10 \%$ & & $15 \%$ & $18 \%$ & $19 \%$ & $21 \%$ & & \\
\hline $0 \%$ & $10 \%$ & & & & & & \\
\hline & 10 a 14 de abril & 18 a 21 de abril & 17 a 19 de maio & 6 a 9 de junho & 12 a 16 de junho & 4 a 7 de junho & \\
\hline
\end{tabular}

O jornal afirma que o candidato Souza é o vencedor, pois sua candidatura está em franca ascensão. Esta afirmação é confiável? Por quê?

\section{Exemplo 2}

A figura ao lado destaca o sólido que restou de um cubo de aresta $a$, após retirar-se dele o prisma BCYXFG, sendo XY paralelo a AD. Se o volume do sólido restante $4 / 7$ do volume do cubo, ache a fração de $a$ que expressa a medida de AX.

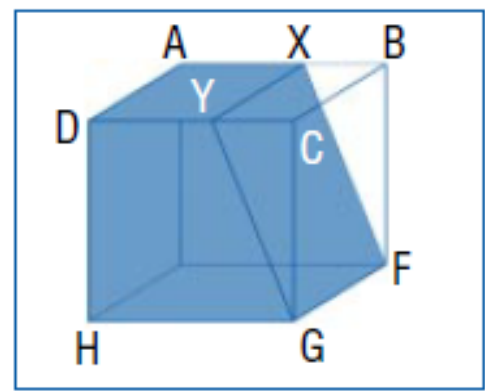

Fonte: BRASIL, 2000, p. 112

Sobre esses dois Problemas, os PCNEM apresentam a seguinte discussão:

O que é preciso saber para enfrentar os desafios propostos nesses problemas? Poderíamos responder que basta saber ler e possuir alguns conhecimentos simples de matemática. Mas, será que é apenas isso? De fato, a leitura é um primeiro passo para enfrentar qualquer uma dessas questões. Contudo, saber ler é mais que ter algum domínio da língua portuguesa. Nesse caso, é necessário também dominar códigos e nomenclaturas da linguagem matemática, compreender e interpretar desenhos e gráficos e relacioná-los à linguagem discursiva. Além disso, o aluno precisa analisar e compreender a situação por inteiro, decidir sobre a melhor estratégia para resolvê-la, tomar decisões, argumentar, se expressar e fazer registros. No primeiro exemplo, seria ainda sensato ter em conta que o crescimento nas intenções de voto pode ser contido ou revertido por novos fatos ou novas informações políticas. E, é claro, também precisa de conhecimentos específicos, como relacionar variáveis, analisar taxas de crescimento, calcular porcentagens e comparar quantidades. Algumas das situações frequentemente apresentadas aos alunos, como é o caso do segundo exemplo, uma questão proposta em um exame de vestibular, são tipicamente "disciplinares", exigem conhecimentos matemáticos específicos. Outras, como no primeiro exemplo, são mais abertas, exigem outras informações além daquelas colocadas no problema, requerem leitura cuidadosa e reflexiva e a necessidade de orquestrar, da melhor forma possível, recursos que envolvem conhecimentos, procedimentos e habilidades de diferentes naturezas. Em resumo, o que se espera é que o aluno seja competente em resolução de problemas, se não 
de todos, pelo menos daqueles que permitam desenvolver formas de pensar em matemática. (BRASIL, 2000, p. 112, grifo nosso).

Verificamos que as características dos Problemas citados como exemplos, de fato, remetem a situações que verificamos nas salas de aula que, em suma, tratam de situações já apresentadas anteriormente. Na primeira situação, além das noções percentuais e estatísticas gerais, como o conceito de "margem de erro", espera-se que o estudante mobilize seus conhecimentos para concluir se a previsão proposta é ou não confiável (sendo "confiabilidade" uma noção subjetiva, nesse caso). Da mesma forma, a segunda questão, apresentada na sequência como sendo uma questão extraída de um vestibular, verifica a capacidade de aplicação direta de definições e propriedades específicas de conceitos matemáticos, sendo, portanto, um exercício de classificação direta. Ainda que, na sequência, o documento reconheça que "a resolução de problemas é peça central para o ensino de matemática, pois o pensar e o fazer se mobilizam e se desenvolvem quando o indivíduo está engajado ativamente no enfrentamento de desafios" (BRASIL, 2000, p. 112), passa ao largo de indicar as maneiras pelas quais 0 Problema pode ser compreendido como desencadeador da aprendizagem matemática, e não apenas como ponto de chegada.

Dessa forma, verificamos que os documentos oficiais que se propõem a indicar parâmetros para o ensino de matemática, e, portanto, indiciam aspectos da atuação profissional do professor tendem a ser constituintes e ratificadores de uma cultura escolar de caráter pragmático, na qual a solução do Problema seria, por si só, evidência de aprendizagem, ainda que seja possível apresentar interpretações que, eventualmente, indiquem o contrário. Entendemos que esses parâmetros oficiais incentivam uma formação para que o aluno se torne capaz de aplicar definições, algoritmos e propriedades estudadas previamente, mais do que uma proposição de Problemas que possibilitem promover e acompanhar o movimento de aprendizagem, a partir de aspectos históricos e sociais de onde possa surgir a necessidade de apropriação do conceito, superando a mera aplicação.

\subsubsection{Base Nacional Comum Curricular}

De acordo com o MEC, "a Base Nacional Comum Curricular (BNCC) é um documento de caráter normativo que define o conjunto orgânico e progressivo de 
aprendizagens essenciais que todos os alunos devem desenvolver ao longo das etapas e modalidades da Educação Básica" (BRASIL, 2018, p. 7, grifo nosso). A introdução, como verificamos, indica o caráter normativo, ou seja, de observação obrigatória do conteúdo do documento. Assim, ao contrário dos PCN que apresentamos anteriormente, que tem caráter norteador, a BNCC é uma norma de observação obrigatória "para a formulação dos currículos dos sistemas e das redes escolares dos Estados, do Distrito Federal e dos Municípios e das propostas pedagógicas das instituições escolares" (BRASIL, 2018, p. 8), inclusive "referentes à formação de professores, à avaliação, à elaboração de conteúdos educacionais e aos critérios para a oferta de infraestrutura adequada para o pleno desenvolvimento da educação" (Idem, Ibidem).

O documento sustenta o objetivo de definir "aprendizagens essenciais que todos os alunos devem desenvolver ao longo da vida" (BRASIL, 2018, p. 7). Esses conhecimentos essenciais definem, no texto, as competências de aprendizagem, que representariam a "mobilização de conhecimentos (conceitos e procedimentos), habilidades (práticas, cognitivas e socioemocionais), atitudes e valores para resolver demandas complexas da vida cotidiana, do pleno exercício da cidadania e do mundo do trabalho" (BRASIL, 2018, p. 18). Dessa forma o documento apresenta o que caracteriza como "competências gerais da Educação Básica", às quais vincula as "competências específicas" das áreas e componentes curriculares. E, para que as competências gerais e específicas se desenvolvam, de acordo com a proposta da Base, são apresentadas habilidades que são, essencialmente, os conhecimentos curriculares a serem estudados durante a educação básica, ou, nos termos apresentados no documento, "as habilidades expressam as aprendizagens essenciais que devem ser asseguradas aos alunos nos diferentes contextos escolares" (BRASIL, 2018, p. 29). Dentre as competências gerais da Educação Básica, verificamos a seguinte:

Compreender, utilizar e criar tecnologias digitais de informação e comunicação de forma crítica, significativa, reflexiva e ética nas diversas práticas sociais (incluindo as escolares) para se comunicar, acessar e disseminar informações, produzir conhecimentos, resolver problemas e exercer protagonismo e autoria na vida pessoal e coletiva (BRASIL, 2018, p. 9, grifo nosso).

De acordo com esta estrutura curricular, normatizada no documento, a capacidade de resolver problemas é uma das competências gerais a ser desenvolvida durante a 
Educação Básica, e os conhecimentos específicos das áreas ou unidades curriculares são apresentados como recursos necessários ao desenvolvimento de tal competência. $A$ proposição, da maneira como é apresentada no documento, mais uma vez, reforça a ideia segundo a qual a resolução de Problemas é finalidade da aprendizagem matemática, omitindo-se em relação ao Problema como meio para se ensinar e aprender, o que ratifica, novamente, uma tendência cultural de que o Problema é recurso de aplicação de conhecimentos ("habilidades", nos termos da Base).

Reconhecemos que o propósito da BNCC seja o de apresentar uma estrutura curricular mínima a ser observada no país, assim entendido o conjunto de conhecimentos essenciais a serem aprendidos durante a escolarização básica, bem como os objetivos principais dessa fase da vida, e que o Problema como desencadeador da atividade de aprendizagem - e de ensino - poderia ser melhor compreendido como aspecto metodológico e/ou didático das práticas de ensino e aprendizagem. Todavia, sendo a Base um documento com o alcance que possui, em razão de ser texto oficial normativo e de circulação nacional, acaba por reforçar - ainda que não possua tal propósito - um estereótipo de que a capacidade de resolver Problemas pragmaticamente seja uma meta a ser alcançada na educação básica e que, para isso, os conhecimentos específicos precisam ser apresentados a priori a fim de se constituírem como "habilidades" que seriam constituintes das "competências".

A imagem representada na figura 3 é ilustrativa dessa nossa interpretação da organização da BNCC. 
Figura 3: Estrutura Curricular da Educação Básica, segundo a BNCC

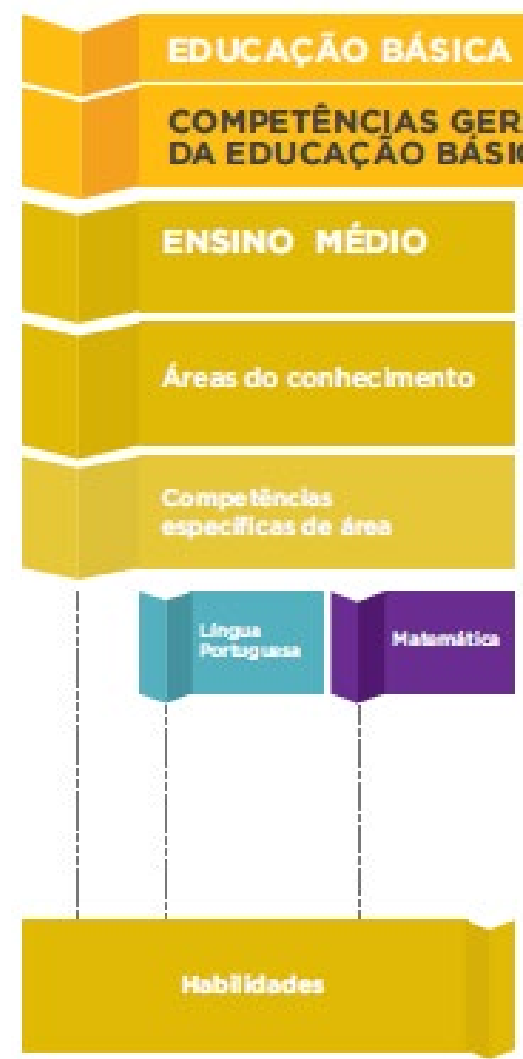

Fonte: BRASIL, 2018, p. 33

Uma interpretação que pode ser feita a partir da imagem, bem como da leitura do texto, traz um caráter de linearidade que não se verifica no movimento de escolarização básica. Segundo essa interpretação a Educação Básica teria um conjunto de "competências gerais" a serem desenvolvidas em todas as suas etapas, dentre elas também o Ensino Médio. Este seria "subdividido" por áreas do conhecimento, que propõem, na essência, evidenciar o caráter interdisciplinar das referidas competências, ou seja, que tais competências poderiam ser desenvolvidas por mais de um componente curricular específico. Na prática, o que se verifica é apenas um agrupamento de componentes curriculares com características afins. Dessa forma os componentes curriculares (disciplinas) desenvolvem as habilidades apresentadas no texto, e estas seriam capazes de promover as competências específicas de cada unidade curricular e, por agrupamento, as de uma área do conhecimento.

Nesse sentido, o licenciando que se depara com o disposto na apresentação geral Base, sem uma formação específica em contrário, tende a reforçar a ideia de que o Problema seria mero recurso de aplicação para verificação do desenvolvimento das 
"habilidades", sem perceber seu potencial como elemento desencadeador de aprendizagem. Essa caracterização dos Problemas vai ficando mais evidente à medida em que a Base passa a tratar, especificamente, da área de matemática nos ensinos Fundamental e Médio.

No Ensino Fundamental, essa área, por meio da articulação de seus diversos campos - Aritmética, Álgebra, Geometria, Estatística e Probabilidade -, precisa garantir que os alunos relacionem observações empíricas do mundo real a representações (tabelas, figuras e esquemas) e associem essas representações a uma atividade matemática (conceitos e propriedades), fazendo induções e conjecturas. Assim, espera-se que eles desenvolvam a capacidade de identificar oportunidades de utilização da matemática para resolver problemas, aplicando conceitos, procedimentos e resultados para obter soluções e interpretá-las segundo os contextos das situações. A dedução de algumas propriedades e a verificação de conjecturas, a partir de outras, podem ser estimuladas, sobretudo ao final do Ensino Fundamental (BRASIL, 2018, p. 265, grifo nosso).

O texto define como um dos propósitos do Ensino Fundamental o desenvolvimento do que denomina "letramento matemático" (BRASIL, 2018), assim entendida a capacidade de "raciocinar, representar, comunicar e argumentar matematicamente, de modo a favorecer o estabelecimento de conjecturas, a formulação e a resolução de problemas em uma variedade de contextos, utilizando conceitos, procedimentos, fatos e ferramentas matemáticas" (BRASIL, 2018, p. 266, grifo nosso). Ou seja, a capacidade de resolver Problemas aplicando conhecimentos estudados é reconhecida no texto como "letramento matemático", uma analogia clara ao letramento na língua materna que supõe a capacidade do uso competente da leitura e da escrita nas práticas sociais, superando a ideia de alfabetização que remete ao processo de aprendizagem onde se desenvolvem as habilidades de ler e escrever (decodificar) (SOARES, 2003; SOARES, 2007; MORETTI e SOUZA, 2015). Em outras palavras ainda, superando a ideia de uma "alfabetização matemática", em que o estudante desenvolvesse as habilidades de contar, medir e calcular, o que se propõe é que o estudante desenvolva a capacidade de uso competente dessas habilidades para o exercício da cidadania e demais práticas sociais. Essa competência seria, de acordo com esta interpretação, sinônima da capacidade de resolver, adequadamente, Problemas em situações cotidianas.

Longe de nós apresentar oposição a esta importante compreensão do Problema na Educação Básica. Ao contrário, compreendemos que este é, de fato, um dos principais 
propósitos da formação escolar. Nossas considerações, no entanto, têm como foco o professor de matemática em formação inicial, que, na falta de uma formação distinta a respeito do papel do Problema na organização do ensino, pode ser levado a considerar estes - a aplicação e a verificação de conhecimentos - como únicos possíveis na formação dos estudantes. A própria Base, dá uma relevante contribuição no sentido de superar a compreensão simplista de que a capacidade de resolver Problemas seja garantia, por si só, de que o estudante desenvolveu as competências esperadas dele. Trata-se da ampliação da noção de "resolver Problemas" para a abranger as noções de formular e resolver Problemas.

\begin{abstract}
Na matemática escolar, o processo de aprender uma noção em um contexto, abstrair e depois aplicá-la em outro contexto envolve capacidades essenciais, como formular, empregar, interpretar e avaliar - criar, enfim -, e não somente a resolução de enunciados típicos que são, muitas vezes, meros exercícios e apenas simulam alguma aprendizagem. Assim, algumas das habilidades formuladas começam por: "resolver e elaborar problemas envolvendo...". Nessa enunciação está implícito que se pretende não apenas a resolução do problema, mas também que os alunos reflitam e questionem o que ocorreria se algum dado do problema fosse alterado ou se alguma condição fosse acrescida ou retirada. Nessa perspectiva, pretende-se que os alunos também formulem problemas em outros contextos (BRASIL, 2018, p. 277).
\end{abstract}

Esse aspecto tem para nós especial importância. Compreendemos que um dos usos dos Problemas durante a formação inicial de professores que ensinarão matemática na educação básica remete a Problemas "padrão", ou seja, Problemas com certas características clássicas que, a partir de "palavras-chave" ou situações tradicionais, indicam a aplicação de determinada "regra" para solução. Ao propor o que caracteriza como "formulação" (talvez a proposta se aproxime mais da ideia de "reformulação"), o documento busca superar a ideia que a aprendizagem está concretizada quando o aluno apresenta uma solução esperada para a questão, ainda que tenha obtido tal solução de maneira mecânica. Quando o aluno se vê diante do questionamento "e se tal variável mudasse?" ele experimenta a necessidade de pensar sobre o conceito e não apenas reproduz um modelo.

Da mesma maneira, os licenciandos tendem a lançar mão de Problemas "padrão" na organização de suas futuras práticas pedagógicas e a acreditar que a solução esperada para esses Problemas indique a aprendizagem do conceito envolvido na solução. Essa foi a razão pela qual sugerimos, em nosso experimento formativo, além da 
análise crítica dos Problemas tradicionalmente utilizados em diversas situações de sala de aula para o estudo de alguns conceitos, também a formulação e reformulação de Problemas. Pretendíamos, com isso, que os Problemas superassem a mera aplicação de definições e propriedades e passassem também a ser desencadeadores de aprendizagem, por suscitar as necessidades humanas que, historicamente, culminaram na produção do que conhecemos hoje, conforme apresentaremos no capítulo 4 .

Com isso, o Problema também assume um papel importante no processo de organização do ensino, não apenas como recurso avaliador da aprendizagem, mas como elemento motivador para que a mesma ocorra.

Enfim, entendemos que, considerando nosso propósito de investigar o movimento dos sentidos pessoais dos licenciandos sobre o conceito de Problema, os textos oficiais pouco contribuem para um processo formativo que privilegie uma abordagem históricológica do currículo, mas ao contrário, minimizam essa possibilidade ou se omitem em relação à importância do Problema na organização do ensino, tanto quanto enfatiza sua utilidade como instrumento de verificação de aprendizagem, de aplicação de conteúdos no cotidiano, de classificação ou reprodução de algoritmos.

No contexto do curso em que o experimento formativo que propusemos foi realizado, de maneira específica, verificamos que as disciplinas que visavam a preparação para o Estágio Supervisionado teriam potencial para investigarmos como os licenciandos compreendiam o papel do Problema na organização do ensino, bem como para acompanhar o movimento dessas compreensões. É com o propósito de apresentar melhor aquele contexto, que tratamos a seguir de alguns aspectos da organização curricular do curso de Licenciatura em matemática do IFSP, campus São Paulo, bem como sobre algumas considerações que pudemos verificar sobre o papel do Problema naquele contexto.

\subsubsection{Projeto Político Pedagógico do curso de Licenciatura em matemática do IFSP-SP}

A atual Lei de Diretrizes e Bases da Educação Nacional (Lei 9.394/1996) estabelece em seu nono artigo que cabe à União "baixar normas gerais sobre cursos de graduação e pós-graduação" e "autorizar, reconhecer, credenciar, supervisionar e avaliar, respectivamente, os cursos das instituições de educação superior e os estabelecimentos 
do seu sistema de ensino" (BRASIL, 1996). Foi em atenção a estes dispositivos legais que foi publicada a BNCC, apresentada na sessão anterior, bem como foi criado, a partir de $2004^{9}$, o Sistema Nacional de Avaliação da Educação Superior - SINAES, realizado pelo Instituto Nacional de Estudos e Pesquisas Educacionais Anísio Teixeira - INEP, órgão vinculado ao Ministério da Educação. A avaliação é composta por três eixos: a avaliação das instituições, dos cursos e do desempenho dos estudantes. Todos os cursos são avaliados em uma escala - Conceito de Curso - que varia de 1 a 5 , sendo 1 considerado "muito ruim" e 5 significa "excelente". Para que um curso seja considerado "aprovado" precisa ser avaliado com Conceito de Curso, mínimo, igual a 3. A eventual "reprovação" do curso pode ensejar diversas sanções, que variam desde a determinação de adequações até o cancelamento da portaria de autorização de funcionamento do curso.

O curso de licenciatura em matemática do IFSP-SPO possui Conceito de Curso igual a 4, o que significa, de acordo com o INEP, que "os objetivos do curso apresentam muito boa coerência, em uma análise sistêmica e global, com os aspectos: perfil profissional do egresso, estrutura curricular e contexto educacional" (INEP, 2015, p. 5, grifo nosso). Com isso, verificamos que a avaliação oficial da estrutura curricular do curso de Licenciatura em matemática a que os alunos do IFSP-SPO, especialmente aqueles que participaram de nossa proposta de formação, estiveram vinculados é considerada, de acordo com os critérios avaliativos estabelecidos pelo INEP, adequada aos objetivos de um curso de formação de professores de matemática. Defendemos que os cursos de licenciatura em matemática devem ser espaços formativos especificamente organizados para o desenvolvimento teórico das competências docentes, ou seja, é no curso de licenciatura em matemática que o estudante aprende não apenas a própria matemática, mas também começa a aprender a ser professor de matemática.

No IFSP os campi organizam as suas propostas pedagógicas autonomamente, ainda que dois campi ofertem o mesmo curso. Com isso, há campi distintos da mesma instituição (IFSP) que ofertam o curso de licenciatura em matemática, por exemplo, sendo que ambos podem ter (e, geralmente têm) propostas pedagógicas e organizações

\footnotetext{
${ }^{9}$ Lei $n^{\circ} 10.861$, de 14 de abril de 2004.
} 
curriculares distintas. Aqui, pelas razões que já citamos relacionadas ao nosso experimento formativo, apresentamos a estrutura curricular do campus São Paulo, onde também ocupamos o cargo de docente.

O Projeto Pedagógico do Curso - PPC da licenciatura em matemática indicava, na época da realização do nosso experimento, como objetivo da formação de professores no curso o desenvolvimento de competências referentes à

[...] dimensão cultural, social e política da Educação. Tais competências favorecem as atividades de pesquisa, o conhecimento pedagógico, as interações com outras áreas, o aprofundamento da compreensão dos significados dos conceitos matemáticos na Educação Básica e de outros conteúdos, além daqueles que o futuro professor vai ensinar, porém articulados com estes. Criase, assim, um campo de aplicação e o aprofundamento na área para uma melhor compreensão do processo de ensino e aprendizagem, com uma transposição didática adequada (IFSP-SPO, 2011, p. 22, grifo nosso).

O conceito de "transposição didática" foi cunhado pelo pesquisador francês Yves Chevallard (1991) e foi por ele definido da seguinte forma:

Um conteúdo de saber que tenha sido definido como saber a ensinar, sofre, a partir de então, um conjunto de transformações adaptativas que irão torná-lo apto a ocupar um lugar entre os objetos de ensino. O 'trabalho' que faz de um objeto de saber a ensinar, um objeto de ensino, é chamado de transposição didática (CHEVALLARD, 1997, p.39, tradução nossa, destaques no original) $^{10}$

Dessa forma, de acordo com a proposta de Chevallard (1997), um certo conhecimento passa a ser caracterizado como objeto a ser ensinado e, a partir daí, passa por "intervenções" didáticas que teriam o propósito de transpor o referido conhecimento para uma forma tal que pudesse ser apropriado pelo estudante. A referência ao conceito no PPC pressupõe, de fato, uma concepção impregnada da proposta chevallariana: a ideia segundo a qual o saber é produzido fora da escola e é por ela apenas absorvido de forma didática para ser aplicado. Nesse contexto, seria desconsiderada a produção de saberes propriamente escolares, bem como o movimento de aprendizagem que decorre dessa produção. Em outras palavras, ao considerar que o conceito de "transposição didática" é explicitado já na indicação do objetivo do curso no PPC temos que reconhecer

\footnotetext{
${ }^{10}$ Livre tradução nossa do trecho: "Un contenido de saber que ha sido designado como saber a enseñar, sufre a partir de entonces un conjunto de transformaciones adaptativas que van a hacerlo apto para ocupar un lugar entre los objetos de enseñanza. El "trabajo" que transforma de un objeto de saber a enseñar en un objeto de enseñanza, es denominado la transposición didáctica"
} 
uma premissa da organização curricular que seria a de que o conhecimento matemático é algo externo às interações sociais que ocorrem no interior do processo educativo e que deveria, portanto, ser transposto segundo aspectos didáticos para ser apresentado aos licenciandos. Estes se apropriariam dessa produção e de técnicas de transposição didática para só então serem capazes de resolver Problemas que envolvessem tais conhecimentos e, consequentemente, só então, poderiam ensinar a mesma matemática (reproduzindo tais técnicas no ensino) a seus futuros alunos.

Essa perspectiva gera um ciclo vicioso que envolve definições prontas, propriedades intrínsecas, exercícios propostos, Problemas de aplicação e avaliações que permitam aferir a capacidade de reprodução de modelos. Entendemos que essa rotina não encontra suporte nas teorias de aprendizagem que consideram como dialético o movimento histórico e cultural de produção do conhecimento, ou seja, aquele em que ao mesmo tempo que o estudante se apropria do conhecimento produzido pela humanidade, ele o transforma e é transformado por ele, de modo que a linearidade do modelo decorrente da ideia chevallariana, não se verifica, porquanto os estudantes não são agentes passivos no processo de aprendizagem e, portanto, produzem um conhecimento que é propriamente escolar.

O PPC do curso indicava que nos três primeiros semestres os licenciandos deveriam participar das disciplinas do bloco "Fundamentos para o Ensino da matemática". A despeito de o título do bloco de disciplinas pressupor uma preparação, desde o início do curso, para aspectos voltados ao ensino de matemática, o plano de organização das disciplinas indicava que seus conteúdos programáticos focavam exclusivamente no estudo de conceitos matemáticos, quais sejam: conjuntos, funções de $1^{\circ}, 2^{\circ}$ graus (referindo-se às funções polinomiais, com polinômios de $1^{\circ}$ e $2^{\circ}$ graus) e modulares; funções exponenciais e logarítmicas; trigonometria; matrizes, determinantes e sistemas lineares; análise combinatória e probabilidade; geometria analítica; números complexos, polinômios e equações algébricas; geometria; e estatística descritiva. Tais conteúdos, em sua maioria, certamente fazem parte do currículo de matemática da educação básica, todavia os programas das disciplinas indicavam exclusivamente a apropriação (ou "aprofundamento") do conteúdo matemático, em detrimento dos aspectos didáticos e metodológicos dos mesmos, no processo de formação do professor. 
Essa opção de organização é aquela segundo a qual, de acordo com Fiorentini e Lorenzato (2007), a formação "[...] tende a conceber a matemática como um fim em si mesma, e [...] a promover uma educação para a matemática priorizando os conteúdos formais dela e uma prática voltada à formação de novos pesquisadores em matemática" (FIORENTINI e LORENZATO, 2007, p. 3). Algumas das disciplinas da organização curricular do curso do IFSP-SPO que visavam oportunizar uma formação que "tende a conceber a matemática como um meio ou instrumento importante à formação intelectual e social de crianças, jovens, adultos e também do professor de matemática do ensino fundamental e médio" (FIORENTINI e LORENZATO, 2007, p. 3) eram as do bloco "Práticas de Ensino". Tais disciplinas estavam vinculadas à realização do Estágio Supervisionado e apresentavam o objetivo de colocar em discussão diferentes propostas didático-metodológicas que subsidiassem as práticas de observação, participação e regência, durante a realização do estágio. A observação caracteriza-se nas aulas em que o aluno estagiário apenas observa o trabalho do professor mais experiente, sem, no entanto, tomar parte nem na condução auxiliar da aula nem na participação tarefas propostas pelo professor supervisor aos alunos. Já a participação verifica-se quando o aluno estagiário contribui para a condução da aula, auxiliando conforme indicações do professor supervisor. Finalmente, as regências são as práticas em que o aluno estagiário fica responsável por toda a organização do ensino, desde o planejamento até a avaliação. Essa última vivência de estágio - regência - constituiu-se como sendo de especial interesse para nós, uma vez que nosso objetivo passava pela organização dessas regências, conforme mostraremos no capítulo 3.

O PPC, no entanto, em atenção ao que dispunha a resolução $n^{\circ} 1$ de 18 de fevereiro de 2002 (BRASIL, 2002), também incorporada pela já apresentada resolução 2/2015, que determinava que "o estágio curricular supervisionado [...] deve ser desenvolvido a partir do início da segunda metade do curso", explicitava que tais disciplinas só poderiam ser cursadas, a partir do $5^{\circ}$ semestre e após o licenciando ter concluído com êxito todas as disciplinas até o terceiro semestre, o que pressupõe uma compreensão, também do dispositivo legal, de que as práticas de ensino têm como prérequisito o domínio do conteúdo matemático tratado nos três primeiros semestres. Não havia, no entanto, restrição similar em relação à necessidade de que os licenciandos 
tivessem cursado com aproveitamento satisfatório, disciplinas voltadas a didáticas ou metodologias, por exemplo, já que, sob a mesma lente que justificaria a restrição à realização do estágio supervisionado condicionada ao aproveitamento das disciplinas de "fundamentos matemáticos", também as "disciplinas pedagógicas" seriam fundamentais às práticas de observação, participação e regência. A questão que caberia seria: Pode o licenciando observar, participar ou reger aulas no estágio sem ter estudado didáticas ou metodologias, por exemplo?

É nesse contexto e no decorrer da oferta regular das disciplinas de Prática de Ensino 3 e 4, que realizamos, durante o segundo semestre letivo de 2017, o experimento formativo em que evidenciamos a necessidade de os licenciandos planejarem o ensino para a regência destacando o uso de Problemas. Os detalhes descritivos do experimento formativo, bem como a apresentação dos participantes e das tarefas e atividades realizadas, serão apresentados no capítulo 3 , quando trataremos dos aspectos metodológicos da pesquisa.

Ainda sobre o PPC da licenciatura em matemática do IFSP-SPO, verificamos que, das 3.291 (três mil duzentas e noventa e uma) horas do curso, apenas 342 horas eram realizadas em disciplinas voltadas à educação, sendo que 199,5 horas (cinco disciplinas de 28,5 horas e quatro disciplinas de 14,25 horas) eram ministradas por professores da área de matemática e 142,5 horas (outras cinco disciplinas) eram consideradas da "área pedagógica" e ministradas por docentes do Departamento de Humanidades - DHU. Havia, ainda, as disciplinas de formação geral, também vinculadas ao DHU, mas sem vínculo direto com a atuação do futuro professor de matemática - ainda que pudessem ser consideradas de grande importância para a formação geral do cidadão (como, por exemplo, as disciplinas de Línguas Estrangeiras - Inglês instrumental e Espanhol instrumental, Qualidade de Vida e Comunicação e Linguagem).

As disciplinas vinculadas ao estágio supervisionado, como vemos, constituíam-se como momentos privilegiados para realização de um experimento formativo voltado ao acompanhamento da aprendizagem da organização do ensino, já que os licenciandos poderiam demonstrar suas compreensões sobre o papel do Problema durante o planejamento da regência bem como poderíamos acompanhar o movimento dessas compreensões. Como o estágio supervisionado obrigatório, nos cursos de licenciatura, 
muitas vezes, representa o primeiro momento em que os licenciandos têm contato direto com as práticas docentes, concluímos que este espaço oportunizaria o desenvolvimento de um saber sobre o processo intencional de organização do ensino.

No IFSP-SPO não havia uma disciplina chamada "Estágio Supervisionado", de modo que o licenciando, quando se matriculava em uma das disciplinas do bloco "Prática de Ensino", seria orientado pelo professor dessa disciplina em relação à realização do estágio supervisionado, preferencialmente, nas escolas públicas da rede paulista de ensino, para realizar as 413,25 horas de estágio previstas na matriz curricular do curso.

Era, portanto, a partir da matrícula nas disciplinas de Prática de Ensino, que o aluno iniciava as práticas de estágio supervisionado. Também não havia pré-requisitos formais de ordenamento para a matrícula nas disciplinas, ou seja, o aluno poderia se matricular primeiro na disciplina Prática de Ensino 3, por exemplo, e iniciar por aí suas atividades de estágio, para depois matricular-se em Prática de Ensino 1, e depois as demais. Todavia, essa prática era explicitamente desaconselhada na organização curricular, em razão da afinidade entre as tarefas desenvolvidas em cada etapa do estágio supervisionado e as aulas das disciplinas do bloco de Prática de Ensino. $\mathrm{Na}$ disciplina Prática de Ensino 1, o licenciando estudava "vivências no ambiente escolar", que subsidiavam as práticas de observação. Em Prática de Ensino 2, o estudo da "formação do profissional" contribuía para a participação nas aulas. Finalmente, nas disciplinas Prática de Ensino 3 e 4, os estudos voltados à "reflexão da prática no ensino" e "trajetória da práxis", respectivamente, pretendiam subsidiar as regências durante o estágio supervisionado.

Tão pouco havia vinculação específica entre a carga horária de estágio cumprida e o aproveitamento nas disciplinas de Prática de Ensino, de modo que seria possível que o aluno fosse aprovado na disciplina sem cumprir uma carga horária de estágio correspondente. Afim de minimizar eventuais percursos acadêmicos em que o licenciando cursasse apenas a disciplina, mas não realizasse o estágio supervisionado correspondente, o PPC previa a necessidade de realização de uma carga horária mínima de $50 \%$ da carga horária total do estágio prevista para o semestre.

Desse modo, para ser aprovado na disciplina Prática de Ensino 1, por exemplo, seria necessário que o licenciando, além do aproveitamento na própria disciplina, 
também cumprisse 28,5 horas de estágio supervisionado, já que a carga horária total de estágio vinculada a essa disciplina era de 57 horas. Para Prática de Ensino 2, que previa 114 horas, o estudante deveria cumprir, no mínimo 57 horas de estágio, para ser aprovado na disciplina, e assim sucessivamente. Essa regra, no entanto, não valia para a disciplina Prática de Ensino 4, que, por ser a última vinculada ao estágio, exigia do licenciando a integralização da carga horária ao seu término. A organização desse bloco de disciplinas está sintetizada no quadro 1 :

Quadro 1: Vínculos entre os estágios supervisionados e as disciplinas de Prática de Ensino

\begin{tabular}{|c|c|c|c|c|c|}
\hline Semestre & $\begin{array}{l}\text { Componente Curricular } \\
\text { vinculado aos estágios }\end{array}$ & Código & Carga horária & $\begin{array}{l}\text { Carga horária } \\
\text { prevista para } \\
\text { o estágio }\end{array}$ & $\begin{array}{l}\text { Supervisão } \\
\text { de estágio }\end{array}$ \\
\hline $5^{\circ}$ & $\begin{array}{l}\text { Prática de ensino } 1- \\
\text { vivência no ambiente } \\
\text { escolar }\end{array}$ & ES1M5 & 28 h 30 min & $57 \mathrm{~h}$ & 28 h 30 min \\
\hline $6^{\circ}$ & $\begin{array}{l}\text { Prática de ensino } 2 \text { - } \\
\text { formação do profissional }\end{array}$ & ES2M6 & 28 h 30 min & $114 \mathrm{~h}$ & $28 \mathrm{~h} 30 \mathrm{~min}$ \\
\hline $7^{\circ}$ & $\begin{array}{l}\text { Prática de ensino } 3- \\
\text { Reflexão e prática no } \\
\text { ensino }\end{array}$ & ES3M7 & 28 h 30 min & 128 h 15 min & 28 h $30 \mathrm{~min}$ \\
\hline $8^{\circ}$ & $\begin{array}{l}\text { Prática de ensino } 4 \text { - } \\
\text { Trajetória da práxis }\end{array}$ & ES4M8 & 28 h 30 min & $114 \mathrm{~h}$ & 28 h $30 \mathrm{~min}$ \\
\hline \multicolumn{3}{|c|}{ Totais } & $114 \mathrm{~h}$ & 413 h 15 min & $114 \mathrm{~h}$ \\
\hline
\end{tabular}

Fonte: PPC - Licenciatura em matemática - IFSP-SPO

$\mathrm{Na}$ tabela, a coluna "Supervisão de estágio" indicava a carga horária das disciplinas de Prática de Ensino vinculadas à preparação para a realização do estágio supervisionado em cada etapa. Nota-se que, no quinto semestre do curso, o licenciando poderia se matricular na disciplina Prática de Ensino 1: Vivência no ambiente escolar e iniciar a realização do estágio supervisionado, com código ES1M5 ${ }^{11}$. A disciplina de Prática de Ensino 1, possuía carga horária de 28h30min (38 aulas semestrais, com 45 minutos cada uma, divididas em 2 aulas semanais ao longo do semestre com 19 semanas). O estágio supervisionado nesse semestre deveria perfazer um total de $57 \mathrm{~h}$. Se o estudante atingisse o mínimo necessário (28,5 horas) ele poderia concluir a disciplina Prática de Ensino 1 - sem prejuízo das demais avaliações da própria disciplina

11 O código faz referência à disciplina, ao curso e ao semestre em que é ofertada na matriz "ideal": Nesse caso, Estágio Supervisionado 1 - matemática $-5^{\circ}$ semestre. 
- e cumprir eventual carga horária faltante em um semestre posterior. Não era permitido, no entanto, que um licenciando matriculado apenas na disciplina Prática de Ensino 1 cursasse, no mesmo semestre, horas excedentes às 57 horas previstas na matriz do curso, e "utilizasse" tal excedente em semestres posteriores para "abater" da carga horária daquele semestre. Com isso, pretendia-se evitar que o licenciando fizesse o estágio supervisionado independentemente das disciplinas que visavam orientar e coordenar aquelas práticas.

A ementa da disciplina de Prática de Ensino 3: Reflexão na prática do Ensino previa

[...] a organização do ensino com destaque para o planejamento e o desenvolvimento de diferentes estratégias de ensino de matemática, permitindo ao licenciando propor atividades que se encaixem às possíveis mudanças nas condutas do professor em sala de aula. Propostas para a análise e o debate são: a relação entre o planejamento e a execução de uma aula, a diferença entre o proposto e a efetiva implementação, e as dificuldades que disso decorrem como a falta de tempo e de material disponível. Além disso, o domínio de conteúdo e o conhecimento de diferentes estratégias de ensino. Serão explorados trabalhos de pesquisa em educação matemática, suas propostas e as estratégias de ensino e os vínculos das pesquisas e de suas possibilidades de utilização na prática escolar (IFSP-SPO, 2011, p. 152).

De maneira similar, a ementa da disciplina Prática de ensino 4: Trajetória da Práxis

previa

[...] o aprofundamento da prática voltada ao debate de ideias que aliam a reflexão sobre as experiências vividas no estágio juntamente à fundamentação teórica dos temas em discussão, ou seja, a práxis do futuro professor. O diálogo é tratado como tema e estudado como um dos fundamentos. Nesse sentido, a prática dialógica torna-se um dos fundamentos dos trabalhos propostos e por isso explorada nas mais diversas manifestações, notadamente no estudo da organização do ensino, com práticas de intervenção e a ideia de projetos escolares que contemplem temas e necessidades Educação Básica. Além disso, em continuidade ao trabalho com as pesquisas na área de educação matemática, a orientação dos licenciandos incentivará a construção de textos que evidenciem a adesão crítica a diferentes autores da literatura que tratem das práticas vivenciadas. São temas deste Componente curricular o estudo da avaliação da aprendizagem, sua concepção, os processos de avaliação e as modalidades de realização (internas e externas), a avaliação em matemática e a relação com o processo de ensino aprendizagem; além de estudos relativos ao livro didático de matemática e da literatura matemática escolar do Ensino Básico. (IFSP-SPO, 2011, p. 165).

A ementa da disciplina Prática de Ensino 4, assim como seu próprio título, remete ao conceito de práxis que, de acordo com Vazquez (1980), pretende um desprendimento 
em relação ao termo "prática" em razão do caráter utilitarista que foi culturalmente impregnado a tal termo na linguagem cotidiana. Ainda que Vazquez (1980) apresente suas considerações em relação à língua espanhola, considerando as similaridades etimológicas e semânticas entre as línguas espanhola e portuguesa, inclusive com a existência específica dos termos "práxis" e "prática", de origem grega, em ambas as línguas, consideramos que o aspecto utilitário que impregna o termo "prática" na língua espanhola também o faz na língua portuguesa falada no Brasil, de modo que reconhecemos a adoção do termo "práxis" no mesmo contexto que Vazquez.

É comum, no senso comum, vermos associações entre o termo "prática" e aquilo que são realizações do professor na execução de sua profissão em sala de aula e, em oposição, a "teoria" compreendida como os momentos externos à sala de aula em que o professor "se prepara" para tal exercício. De fato, Vazquez (1980) nos alerta que, no senso comum, o termo "prática" é compreendido em um contexto de utilitarismo. Nesse entendimento, enquanto os licenciandos estão em formação, eles vivenciam "teorias" e só quando vão para sala de aula, atuar profissionalmente, é que eles passam a experimentar "a prática". A proposta de Vazquez (1980) vai de encontro a essa caracterização usual e marca sua superação adotando o termo "práxis" para destacar um movimento que compreende uma relação dialética, consciente e objetiva entre diversas ações que outrora designávamos como "teoria" ou "prática", como se fosse possível distinguir momentos em que os exercícios são "teóricos" e outros em que são "práticos".

No entanto, notoriamente, a ementa não referenciava, diretamente, Vazquez ou sua filosofia da práxis, o que levantaria o questionamento de até que ponto tal menção, de fato, consideraria os aspectos da concepção vazqueziana e, ainda que seja esse o propósito, a interpretação da ementa nesse contexto dependeria enormemente do conhecimento prévio do professor a respeito do tema. Caso o professor não reconhecesse a distinção entre os termos concluiria, provavelmente, que "práxis" e "prática" são apenas sinônimos, como o são na língua portuguesa corrente, passando a conferir a ambos o mesmo caráter utilitarista que Vazquez (1980), como já indicamos, buscava superar.

Em continuação, além das 57 horas equivalentes ao somatório dessas duas disciplinas de Prática de Ensino, apenas outras 14,5 horas - da disciplina Coordenação 
de Prática 3 (1 aula por semana) - remetiam a indicações do PPC do curso de licenciatura em matemática do IFSP-SPO, voltadas a ações formativas que visavam o desenvolvimento das habilidades relacionadas à organização do ensino. Assim, tínhamos um total de 71,5 horas voltadas especificamente ao desenvolvimento dessa competência, de um total de 3291,25 horas de curso, o que equivalia a $2 \%$ de formação voltada à aprendizagem da organização da práxis pedagógica no curso inteiro.

Reconhecendo a inexpressão dessa proporção em razão da importância de uma formação especialmente voltada ao desenvolvimento dessa competência, optamos por atuar em duas frentes: a defesa de uma reforma curricular, no âmbito daquela instituição, que colocasse em evidência uma formação com equidade entre a apropriação do conhecimento matemático e sobre a referida práxis pedagógica e, paralelamente, a iniciativa de potencializar, tanto quanto possível, as oportunidades de reflexão sobre essa práxis voltada à organização do ensino dentro da estrutura curricular vigente à época do experimento formativo.

Esta última frente estava mais diretamente vinculada ao nosso interesse de pesquisa já que, ao oportunizar a aprendizagem de aspectos relacionados à organização do ensino, poderíamos acompanhar o movimento dos sentidos pessoais dos licenciandos sobre o papel do Problema. Alicerçados pelo arcabouço teórico e metodológico históricocultural, poderíamos oportunizar que

[...] o professor ao planejar suas ações prevê a necessidade de momentos de produção em grupos e de socializações de tais produções não apenas como uma "dinâmica" para inovar suas aulas, mas porque entende que tais estratégias criam condições para que se estabeleçam mediações necessárias entre alunos e o conhecimento de forma que se dê a aprendizagem por meio das apropriações que os sujeitos estabelecem sobre conhecimentos que são construções sóciohistóricas (MORETTI, 2007, p. 104).

Com isso poderíamos, no contexto da formação, proporcionar aos licenciandos a oportunidade de conhecer e se apropriar de uma proposta de organização do ensino, intencionalmente planejada para acompanhar os sentidos sobre Problemas como recurso didático desencadeador da aprendizagem e norteador das situações didáticas que potencializassem as atividades de ensino e de estudo.

Como também já indicamos, o momento adotado para tal movimento incluiu o estágio supervisionado, por entendermos este como um momento privilegiado naquela 
organização curricular para promover um movimento formativo que potencializasse a aprendizagem da organização da atividade pedagógica, abrangendo momentos de estudo teórico dos conceitos, planejamento de situações desencadeadoras de aprendizagem, execução das ações planejadas e o movimento de avaliação. A seguir, apresentamos algumas considerações sobre o estágio supervisionado e sua importância no contexto de estudos histórico-culturais.

\subsection{O Estágio Supervisionado nos cursos de Licenciatura em matemática}

Ainda que corramos o risco de resumir demasiadamente um tema tão importante, como o Estágio Supervisionado, acreditamos ser fundamental apresentar, nesta subseção 1.3, aspectos que consideramos merecedores de destaque em razão de o Estágio Supervisionado ter se constituído como um importante momento para oportunizar aos licenciados que participaram da pesquisa a vivência de práticas relacionadas ao cotidiano escolar. Assim, tem esta subseção a intenção de reafirmar a importância das práticas relacionadas ao estágio nos cursos de licenciatura, sobretudo naquele que abarcou nossa pesquisa, em razão de a matriz curricular que apresentamos no subitem anterior, 1.2.4, privilegiar a formação do matemático em detrimento da formação do professor de matemática, de modo que as práticas relacionadas ao estágio supervisionado se constituíram, naquele contexto, como um dos poucos momentos em que os licenciandos poderiam experimentar uma formação mais voltada à aprendizagem da docência de matemática, em relação à aprendizagem da matemática como fim em si mesma.

Iniciamos destacando a, já citada, resolução 2/2015 como sendo a norma que determina a obrigatoriedade da realização de, pelo menos, 400 horas de estágio supervisionado para a conclusão dos cursos de formação de professores. Essa determinação está intimamente relacionada ao entendimento de que a inserção do licenciando em um ambiente onde a prática docente está sendo exercida é condição necessária - mas não suficiente - durante o processo de formação.

O estágio é um momento privilegiado na formação do professor em que, geralmente, se oportuniza pela primeira vez que os licenciandos experimentem vivências pedagógicas, tomadas de decisão e posturas diante de situações que regularmente se apresentam ao cotidiano dos professores. 
Nossos alunos, muitas vezes, assumem a sala de aula como professores sem terem passado por situações de aprendizagem que os coloquem em condições de planejarem suas aulas a partir de experiências vividas ainda como estudantes. Sendo-se assim, sentem-se surpresos e despreparados para lidar com a dinâmica de funcionamento de uma escola e, em particular, com a sala de aula. É necessário que percebam o modo como se faz o ensino em uma escola (MOURA, 1999, p.10).

De acordo com a resolução que dá diretrizes para a estruturação dos cursos "o estágio curricular supervisionado é componente obrigatório da organização curricular das licenciaturas, sendo uma atividade específica intrinsecamente articulada com a prática e com as demais atividades de trabalho acadêmico" (BRASIL, 2015, p. 12). Para Pimenta e Lima (2005, p. 6), a realização do estágio objetiva a "interação dos cursos de formação com o campo social no qual se desenvolvem as práticas educativas". Logo, a realização do estágio supervisionado constitui uma das primeiras oportunidades de o licenciando experimentar o planejamento, a organização, a regência de aula e a avaliação do ensino e da aprendizagem.

Ainda de acordo com Pimenta e Lima (2005, p. 7) "o exercício de qualquer profissão é prático, no sentido de que se trata de aprender a fazer 'algo' ou 'ação'. A profissão de professor também é prática". As autoras revelam preocupação com a verificação de que a imitação dos modelos observados em sala de aula constitui-se como principais referências didáticas e metodológicas para os estagiários e futuros professores (PIMENTA e LIMA, 2005). Entendemos que tal imitação de métodos, em relação ao curso de licenciatura em matemática, decorre do relativo silêncio em relação à formação especificamente destinada à apropriação de diferentes propostas metodológicas e do desconhecimento por parte dos professores-formadores das diversas possibilidades didáticas e metodológicas. Concordamos com Pimenta e Lima quando afirmam que, tradicionalmente, diferencia-se, nos cursos de formação de professores, a "teoria", como sendo os aspectos estudados nos livros e durante as aulas, da "prática", entendida como as aplicações em sala de aula durante a atuação do docente. Segundo elas essa concepção culmina no entendimento de que o modo de aprender o fazer docente pressupõe a "observação, imitação, reprodução e, às vezes, a reelaboração dos modelos existentes na prática, consagrados como bons" (PIMENTA e LIMA, 2015, p. 7).

Também reconhecemos a necessidade de superação, não apenas dessa dicotomia entre "teoria" e "prática", mas, sobretudo, da ideia segundo a qual o 
conhecimento proporcionado a partir do estágio supervisionado seria exclusivamente empírico, em favor do entendimento de que durante a preparação e realização do estágio supervisionado, assim como em todos os momentos da formação inicial do professor de matemática, tem-se uma formação perpassada pela unidade dialética entre teoria e prática, que constitui a práxis.

Para Gama e Sousa (2015, p. 35) é no decorrer do estágio supervisionado que o professor supervisor, aquele que atua na educação básica e que, portanto, recebe em sua sala de aula, o licenciando estagiário, contribui com os processos formativos compartilhando experiências enquanto planejam e realizam coletivamente as atividades referentes ao estágio. Também indicam o potencial do estágio supervisionado para explicitar a parceria entre escola e universidade, a intencionalidade nos processos formativos dos agentes envolvidos, a ampliação do sentimento de pertencimento do licenciando ao ambiente escolar, uma convergência de entendimentos dos envolvidos nas práticas de estágio quanto ao papel da escola e do ensino de matemática escolar e a conscientização sobre a importância de o professor ser pesquisador de sua própria prática (GAMA e SOUSA, 2015, p. 36).

Concordando também com Moura (1999) sobre a importância de superar uma compreensão "de que nos institutos (de matemática e física) se aprendem as disciplinas de conteúdo específico e na Faculdade de Educação as de ensino" (MOURA, 1999, p. 9), que abarca a dicotomia entre conteúdo matemático e o pedagógico, compreendemos que o estágio seja espaço com "objetivo de integrar as ações dos professores de prática de ensino e os professores das escolas onde acontecem os estágios" para "desempenhar, na formação do professor, um papel semelhante ao da residência na formação do médico" (MOURA, 1999, p. 9 e 10). Moura (1999) entende, ainda, que a atividade de ensino, ao ser planejada conjuntamente, pode gerar elementos de reflexão e, por conseguinte, a tomada de consciência pelo futuro professor sobre os diversos aspectos a serem considerados durante a atividade pedagógica.

Nas propostas de organização dos cursos de licenciatura, de acordo com Moura (1999, p. 142), o estágio tem organização supradisciplinar e deve desenvolvido ao longo da formação do professor. Assim, eleva-se a relevância do processo coletivo de formação de professores, já que se envolvem diversos agentes - o professor formador, o professor 
supervisor, o licenciando, as equipes da escola, as equipes da universidade evidenciando a importância de os cursos de licenciatura desenvolverem visão crítica sobre os processos formativos e oportunizarem uma superação da dicotomia teoriaprática em favor de um entendimento em que esses aspectos se completam em uma interação dialética.

Já para Silva e Cedro (2015, p. 44) a formação decorrente do estágio supervisionado, pressupõe o reconhecimento da necessidade de uma organização da aprendizagem da (e "para a") docência, possibilitando a vivência do planejamento coletivo de atividades de ensino, a reflexão sobre as ações adotadas, a superação da alienação do processo formativo e a criação de um espaço de produção intencionalmente organizado para tal fim. De acordo com os autores, tanto professores formadores quanto licenciandos, permanecem alienados durante o processo formativo que envolve o estágio supervisionado, em decorrência da precariedade como as propostas de realização desse estágio são apresentadas (SILVA e CEDRO, 2015, p. 45).

A superação, indicada por Silva e Cedro (2015), presume uma concepção dialética materialista do conceito de alienação. Entendemos que o sujeito permanece alienado quando não toma consciência dos processos e relações do homem com o mundo e estes, por consequência, não satisfazem a nenhuma necessidade do próprio sujeito. Ainda em conformidade com Lima e Cedro, "o estágio deve ser visto como uma atividade em que os futuros professores, durante seu processo de formação, tenham oportunidade de articular, de forma ininterrupta o aprender e o ensinar" (SILVA e CEDRO, 2015, p. 49). De acordo com esses autores, "existe um modo geral de ação docente referendada na teoria histórico-cultural e em seus desdobramentos" segundo o qual a aprendizagem dos processos de organização da atividade de ensino pode se consolidar (idem, ibidem, p. 73). É em concordância com essa perspectiva que nossa pesquisa elege os movimentos decorrentes do estágio supervisionado para analisar aspectos relacionados aos sentidos pessoais dos licenciandos sobre o papel do Problema na práxis docente, durante o curso de licenciatura em matemática.

Verificamos que as organizações dos cursos de licenciatura em matemática preveem a realização do estágio curricular em atenção à determinação normativa. Todavia, as formas de articulação entre o estágio e os aspectos formativos do 
licenciando, enquanto professor, geralmente levam os alunos a classificar o estágio supervisionado como uma "burocracia" que se impõe para a conclusão do curso. Os motivos que levam os licenciandos a realizar seus estágios supervisionados, geralmente, se resumem a cumprir essa, assim chamada, "burocracia".

Portanto, entendemos que o estágio supervisionado, nos cursos de licenciatura, deve cumprir o papel de oportunizar a troca de experiências, a articulação entre conhecimentos matemáticos e opções didático-metodológicas, a organização da atividade de ensino e, tanto quanto possível o desenvolvimento e aprimoramento das diversas capacidades inerentes à atividade pedagógica. Durante a preparação para a realização da regência no estágio supervisionado pudemos acompanhar o movimento dos sentidos pessoais dos licenciandos sobre o papel do Problema na práxis pedagógica.

No próximo capítulo trataremos de aspectos relacionados ao conceito de Problema em algumas publicações da área de educação matemática e na Teoria Histórico cultural, a fim de indicar possíveis influências destes nos sentidos pessoais dos licenciandos a respeito do tema. 
CAPÍTULO 2

O conceito de Problema e a TeOria HistóRico-Cultural 


\section{O conceito de Problema e a Teoria Histórico-Cultural}

Uma questão, em si, não caracteriza o problema, nem mesmo aquela cuja resposta é desconhecida; mas uma questão cuja resposta se desconhece e se necessita conhecer, eis aí um problema.

Demerval Saviani ${ }^{12}$

A epígrafe deste capítulo sugere refletir sobre: o que seria um problema? E ainda mais: para o ensino de matemática, o que seria um bom Problema? O discurso recorrente em documentos oficiais, livros e debates acadêmicos parece pressupor que a ideia de Problema que temos atualmente é tão antiga quanto a própria Matemática e que os Problemas sempre tiveram no ensino escolar o mesmo papel que têm atualmente e que assim deve permanecer. Mas permanecem as questões: o que é um problema para um sujeito é, necessariamente, um problema para outra pessoa também? Quando o aluno desconhece a resposta a uma questão de matemática, mas domina determinado algoritmo ou operação matemática que, se aplicado adequadamente, indicará a resposta certa, ele está diante de um Problema? Em busca de respostas a estes questionamentos, colocamos em pauta algumas perspectivas históricas que envolvem o conceito de Problema e qual seria o seu papel nos processos educativos relacionados à matemática escolar.

De acordo com Moura, et. al. (2011), os conceitos são instrumentos simbólicos que possibilitam ações mediadas que relacionam objetos e fenômenos. Para esses autores

[...] se, diante de um objeto estranho ao nosso cotidiano, somos informados de que se trata de um instrumento musical, a palavra "instrumento musical" remetenos a conceitos que subsidiam nosso pensamento a respeito de quando ele é utilizado, com que finalidade e quais os possíveis modos de ação com ele. No entanto, se nos dissessem que se trata de uma "peça de uma máquina", os conceitos de "peça" e "máquina" induziriam outros pensamentos, outras imagens mentais em face do mesmo objeto. Os conceitos tornam-se instrumentos nossos quando conseguimos pensar com eles, estabelecer relação entre seu significado social e o sentido pessoal que Ihes atribuímos (MOURA, SFORNI e ARAÚJO, 2011, p. 44).

A mesma ideia aplica-se também à compreensão sobre o que seriam os conceitos científicos, de modo que são aqueles em que "estão presentes ações mentais

12 SAVIANI, Demerval. Educação: do senso comum à consciência filosófica. 13. ed. Campinas: Autores Associados, 2000. p. 21. 
objetivadas, [e nos quais] a realização de ações é o caminho necessário à sua apropriação como instrumento simbólico da atividade humana" (MOURA, SFORNI e ARAÚJO, 2011, p. 44). Dessa forma, para nós, em nossa pesquisa, o Problema constituise como um conceito científico sintetizado na palavra "Problema", que remete a uma produção humana acumulada e, consequentemente, possui um significado social.

Especificamente, trataremos do conceito de Problema no contexto da organização da atividade pedagógica. Para Bernardes (2006), a atividade pedagógica é a unidade dialética entre a atividade de ensino e a atividade de estudo e representa o contexto no qual a aprendizagem promove o desenvolvimento das Funções Psicológicas Superiores, conforme indicaremos no subcapítulo seguinte, 2.1. Nessa unidade dialética a atividade de ensino é a atividade do professor e a atividade de estudo (ou, melhor, de aprendizagem, já que podemos entender que o professor, na atividade pedagógica, também estuda) é a atividade do aluno. Entendemos que a objetivação da atividade pedagógica é potencializada no contexto da realização da Atividade Orientadora de Ensino - AOE (MOURA, et al., 2017).

A necessidade de elaboração e do aperfeiçoamento do modo de formar, aperfeiçoar e orientar o desenvolvimento da criança, moral e intelectualmente, foi o que nos levou a conceituar os princípios teórico-metodológicos que orientam e realizam a atividade de ensino como Atividade Orientadora de Ensino (AOE). Ao acrescentarmos a palavra "orientadora" ao conceito de atividade de ensino, destacamos o aspecto intencional de quem ensina. Mas não é apenas isso. Queremos ressaltar que não basta colocar a criança em ação. É preciso que o professor e o estudante tornem-se sujeitos da atividade no seu processo de desenvolvimento. (MOURA, et al., 2017, p. 84)

O caráter intencional e a premissa de que professores e estudantes devem tornarse sujeitos do processo de desenvolvimento fazem com que o Problema assuma na AOE características desencadeadoras da aprendizagem. São dessas características que trataremos neste capítulo.

Entendemos que as diversas possíveis compreensões sobre o que seria um Problema e qual seria seu papel na aprendizagem, na docência e na aprendizagem da docência passa pelos diferentes modos de se compreender aspectos da atuação do professor em sala de aula, bem como pelas distintas concepções teóricas ou metodológicas que permeiam o trabalho pedagógico. Apresentaremos também algumas dessas compreensões sobre o conceito de Problema que aparecem em pesquisas que 
envolvem este que, como já afirmamos, é tema de grande interesse da área de Educação Matemática, e das maneiras como essas compreensões parecem influenciar sentidos pessoais e vão constituindo um significado social a respeito do que seria um Problema e qual seria seu papel na organização do ensino.

Antes, porém, de tratar do Problema, nesse contexto, consideramos importante apresentar alguns aspectos da perspectiva teórica que perpassam nossas compreensões a respeito da presença do Problema na educação matemática.

\subsection{Teoria Histórico-cultural: aspectos da aprendizagem e desenvolvimento humano.}

A Teoria Histórico-cultural - THC tem sua origem com Lev Semenovich Vygotsky (1896-1934). Durante sua curta e profícua vida ele "chegou a elaborar cerca de 200 estudos científicos sobre diferentes temas e sobre controvérsias e discussões da psicologia contemporânea e das ciências humanas de um modo geral" (REGO, 2010, p. 15). A teoria psicológica de Vygotsky buscava, dialeticamente, "integrar, numa mesma perspectiva, o homem enquanto corpo e mente, enquanto ser biológico e ser social, enquanto membro da espécie humana e participante de um processo histórico" (OLIVEIRA, 1993, p. 23).

O contexto que levou Vygotsky a propor sua teoria era o de uma crise entre vertentes diametralmente opostas da psicologia. De um lado a psicologia experimental (ou natural), que buscava validar processos elementares sensoriais e reflexos, a partir da aproximação com métodos de outras ciências experimentais, como a física e a química, tornando o homem, basicamente corpo (OLIVEIRA, 1993, p. 22). De outro lado a psicologia mental, que descrevia as propriedades dos processos psicológicos superiores, compreendendo o homem como um conjunto mente-consciência-espírito. Vygotsky coloca sua teoria como uma alternativa de superação dessa crise, propondo uma síntese entre as duas abordagens (idem, ibidem, p. 23).

Oliveira (1993) alerta que, nesse contexto, a ideia de síntese é central para a compreensão da proposta psicológica de Vygotsky, não representando mera adição ou justaposição de ideias, mas fazendo emergir algo novo, inexistente anteriormente, tornado possível apenas na integração entre os elementos que the deram origem. De fato, podemos compreender que a síntese proposta por Vygotsky não caracteriza a 
adição ou justaposição das vertentes que defendiam, em oposição, o ser humano como ser biológico ou como ser psíquico. A superação dessas vertentes, tão pouco, pressupõe que a essência de cada uma deva ser relegada ao esquecimento. Ao contrário, a ideia de superação, na THC, deve remeter ao entendimento de que a produção cultural que Ihe antecede não satisfaz adequadamente à necessidade que lhe coloca em pauta.

De acordo com Moretti, et al. (2017), a proposição de Vygotsky pretendia superar uma tendência metodológica predominante à época, denominada "estímulo-resposta". Ainda que reconhecesse, conforme Vygotsky (1991, p. 42), que "a adoção da estrutura estímulo-resposta pela psicologia introspectiva nos idos de 1880 foi para a psicologia um avanço revolucionário, uma vez que a trouxe para mais perto do método e espírito das ciências naturais e preparou o caminho para as abordagens psicológicas objetivas que se seguiram", ele (VYGOTSKY, 1991, p. 43) demonstrou que "uma estrutura estímuloresposta para a construção de observações experimentais não pode servir como base para o estudo adequado das formas superiores, especificamente humanas, de comportamento".

Essas formas superiores de comportamento remetem às funções psicológicas superiores - FPS. De acordo com Vygotsky (2001, p. 309) as FPS, como a atenção voluntária, a memória lógica, a imaginação criativa, o pensamento por conceitos e a linguagem, "têm uma base similar e se tomam superiores em função da sua tomada de consciência e da sua apreensão" em decorrência de serem processos sociais mediatizados por símbolos e signos, como a fala e a linguagem, e têm sua origem na existência de na interações entre indivíduos em grupos sociais, seguindo um movimento que parte de aspectos interpsíquicos (externos) para aspectos intrapsíquicos (internos). Ele entende, ainda, que "funções psicológicas superiores não se encontram superpostas, como um andar superior, sobre os processos elementares; elas representam novos sistemas psicológicos" (VYGOTSKY, s/d, apud JOHN-STEINER e SOUBERMAN, 1991, 82). As abordagens baseadas em estímulo-resposta, segundo seu entendimento, colocariam em tela as funções psíquicas elementares, mas não as superiores.

As funções elementares seriam aquelas que remeteriam a comportamentos primitivos, verificáveis inclusive nas outras espécies animais, e diferem das superiores, como vimos, pela consciência e assimilação. Em outras palavras, a distinção entre o comportamento de um homem e de um macaco que utilizam um galho para alcançar um 
fruto em uma árvore é que o macaco o faz de maneira instintiva, movido pela necessidade imediata de saciar sua fome, e o faz se o galho se lhe apresenta ao campo visual, enquanto que, por outro lado, o homem busca pelo galho conscientemente de seu uso como instrumento para realização de um trabalho. Ele é capaz de pensar no galho em sua mente e na função que deseja empregar-lhe, sendo capaz de deixar momentaneamente a árvore e seu fruto para buscar um galho que sirva ao seu objetivo, retornando posteriormente para aplicar seu plano. Nesse contexto, "o galho deixa de ser 'natureza' - objeto natural - e transforma-se em instrumento - objeto cultural" (MOURA, SFORNI e ARAÚJO, 2011, p. 42).

O animal, inclusive o mais inteligente, é incapaz de desenvolver as suas faculdades intelectuais através da imitação ou da aprendizagem. Ele não é capaz de assimilar nada de essencialmente novo em comparação com o que já sabe. É capaz apenas de decorar através do adestramento. Neste sentido, é possível afirmar que o animal não pode ser ensinado, se entendermos o ensino no sentido especifico do homem. Na criança, ao contrário, o desenvolvimento decorrente da colaboração via imitação, que é a fonte do surgimento de todas as propriedades especificamente humanas da consciência, o desenvolvimento decorrente da aprendizagem e o fato fundamental (VYGOTSKY, 2001, p. 330-331).

A busca pela superação das abordagens baseadas em estímulo-resposta potencializou o reconhecimento, por parte de Vygotski (1991, p. 43), de que "o comportamento humano difere qualitativamente do comportamento animal, na mesma extensão em que diferem a adaptabilidade e desenvolvimento dos animais" e defende que "o desenvolvimento psicológico dos homens é parte do desenvolvimento histórico geral de nossa espécie e assim deve ser entendido".

A maneira pela qual a aprendizagem promove o desenvolvimento tem importantes implicações na organização do movimento formativo que adota pressupostos da THC. Por essa razão, entendemos adequado apresentar aspectos teóricos do método, cujas implicações na nossa pesquisa serão retomadas no capítulo 3 .

\subsubsection{Aprendizagem e Desenvolvimento no contexto da THC}

O Homem não é um ser passivo diante da natureza. Ele possui capacidade de apropriação da produção cultural histórica da própria espécie. Ao nascer, o indivíduo ser biológico - é inserido em uma sociedade que possui uma ampla produção cultural. A linguagem possibilita que esse indivíduo se torne sujeito da produção dessa cultura, ao 
mesmo tempo em que se apropria dela. Por isso dizemos que há uma relação dialética. De acordo com Leontiev (1978) o homem é diferente dos outros animais em razão de sua capacidade de conhecer a si próprio e o ambiente ao seu redor, de modo a poder transformá-lo, bem como em razão da capacidade de transmitir a cultura de que se apropriou e aquela que produziu, de maneira intencional, aos seus descendentes. Enquanto a evolução biológica segue em um ritmo inevitavelmente "lento", a libertação total da necessidade de "aguardar" essa evolução biológica, coloca o homem em um novo patamar evolutivo regido pelas leis sócio-históricas.

Assim, entendemos que o homem possui necessidades que superam a mera sobrevivência biológica, e tais necessidades são produto da própria ação humana. Por exemplo: para satisfazer sua necessidade imediata de se alimentar, a espécie humana aprendeu que poderia plantar sementes para obter da terra o alimento. O plantio tornase, então, uma necessidade criada pela atuação do homem sobre o meio, que supre a necessidade de alimentar-se. Para plantar, o homem constrói máquinas, ferramentas ou processos que possibilitam o plantio e o controle da plantação, como a adubação, a irrigação, etc. Conhecer tais instrumentos, torna-se, então, uma nova necessidade. Esses instrumentos podem ser automatizados, melhorados, precisam de manutenção, etc. E esses novos aspectos geram novas necessidades e vão enriquecendo a produção cultural. Cada novo indivíduo que nasce é colocado diante dessas necessidades e, ao se apropriar dos modos de satisfação delas, se vê diante da possibilidade de amplia-las. As novas gerações da espécie não precisam aprender "do zero" como satisfazer às suas necessidades mais básicas, podendo atuar na produção de uma cultura que possibilita a ampliação das mesmas. Esse trabalho de produção material da cultura é o que caracteriza o materialismo histórico-cultural e possibilita, dialeticamente, o desenvolvimento ontogenético - do sujeito - e o desenvolvimento filogenético - da espécie.

De acordo com Rigon, Asbahr e Moretti (2016, pp. 19-20) "para que uma atividade se configure como humana, é essencial, então, que seja movida por uma intencionalidade, sendo esta, por sua vez, uma resposta à satisfação de necessidades que se impõem ao homem em sua relação com o meio em que vive". A necessidade impulsiona a apropriação da cultura historicamente produzida e o desenvolvimento da 
espécie e do sujeito, que podem, então, transmitir, intencionalmente, uma cultura mais "rica" à geração seguinte e assim sucessivamente. As modificações na cultura inseridas pelo homem durante esse processo de humanização, produzem não apenas mudanças biológicas, mas também psicológicas e essas mudanças biológicas e psicológicas, por sua vez, possibilitam novas mudanças culturais a serem apropriadas, dando continuidade ao processo, ou seja, se desenvolvendo. Em outras palavras, à medida em que o sujeito se apropria da essência humana, produto histórico-cultural, - ou seja, à medida em que aprende - ele modifica o meio ao seu redor, a si próprio e sua psique, o que possibilita novas produções culturais a serem aprendidas, que possibilitarão novas mudanças, etc., constituindo o desenvolvimento da espécie e dos sujeitos envolvidos nesses processos.

É neste contexto que podemos entender que a educação é humanizadora, já que é a partir dela que o indivíduo da espécie humana se apropria da cultura historicamente produzida e pode ser reconhecido como humano. Em outras palavras, aquilo que há de humano no indivíduo da espécie não decorre apenas das características biológicas que Ihe são específicas, mas também da apropriação cultural que decorre de sua atividade humana.

Fica claro, então que, de acordo com a THC, aprendizagem e desenvolvimento não podem ser entendidos como sinônimos, ainda que sejam processos dialeticamente relacionados, apesar de outras vertentes psicológicas pressuporem o contrário. Vygotsky contrapõe, por exemplo, as ideias do psicólogo estadunidense Edward Lee Thorndike (1874-1949), que compreendia que aprender e se desenvolver seriam a mesma coisa.

Sobre as ideias de sua época sobre desenvolvimento e aprendizagem, Vygotsky discute três teorias que se contrapõem entre si: uma que os desvincula, entendendo que o desenvolvimento precede a aprendizagem, de modo que só seria possível aprender aquilo para o qual o indivíduo já estivesse, naturalmente, desenvolvido ("maduro"); uma que os identifica absolutamente, de modo que aprendizagem e desenvolvimento seriam sinônimos, a despeito de tudo o que os opõe, na qual Vygotsky localiza Thorndike como um de seus representantes; e uma terceira, na qual a aprendizagem possibilita o desenvolvimento e este potencializa novas aprendizagens.

Para Vygotsky (2001), a terceira vertente suscitava um novo problema: o da possibilidade de que o que se aprende pudesse desencadear um processo de 
desenvolvimento, ou seja, aquilo que se aprende estaria impregnado do próprio conteúdo e de algo mais, o que acarretaria um desenvolvimento para além da aprendizagem.

Thorndike refutava a possibilidade de transferência natural entre o conhecimento adquirido em lições previamente ensinadas e a capacidade de raciocínio a ser empregada na solução de diversas outras situações. Em um manual voltado para suas considerações acerca do ensino de aritmética, Thorndike afirma que seria fundamental que

[...] os enunciados dos Problemas ou das atividades desenvolvidas pelo aluno contivessem 'elementos idênticos' a situações que acontecessem fora do ambiente escolar. Era a presença de elementos idênticos que, segundo Thorndike $(1905,1913)$ garantiria que uma conexão fosse estabelecida e a aprendizagem ocorresse, pois para o autor aprendizagem é conexão (SANTOS, 2006, p. 137).

Thorndike (1936) entendia por conexão a possibilidade de se estabelecer relações entre aspectos da vida cotidiana fora da escola, a que ele refere-se utilizando o termo "realidade", com a vida escolar do aluno. Para ele, aprendizagem seria a capacidade de relacionar adequadamente aquilo que se aprende na escola com os diversos aspectos que se apresentam na vida "fora da escola". Para possibilitar essas conexões, Thorndike defendia que os Problemas deveriam despertar o interesse em encontrar uma solução e colocar o aluno em atividade ${ }^{13}$ para resolvê-lo.

Essa crítica, à luz de sua teoria, justificava-se: Thorndike descreveu três indicadores do desenvolvimento psicológico humano, que ele chamou de lei da prontidão, lei do efeito e lei do exercício. Segundo ele, diante de um Problema a criança deveria reconhecer nele os elementos idênticos à sua realidade e poderia estabelecer a conexão entre o estímulo (Problema) e a resposta (solução correta), constituindo a lei da prontidão, já que ela estaria sempre pronta a resolver situações que demandassem aquele conhecimento; A solução correta, por sua vez, geraria o prazer (consequência agradável) que seria a relação que Thorndike denominou lei do efeito. Por fim, motivado pela

\footnotetext{
13 Importante registrar que Thorndike utiliza o termo "atividade" em sentido lato, no senso comum, significando que seria necessário que o aluno pensasse e agisse espontaneamente para criar as conexões que culminariam na aprendizagem, em detrimento de uma proposta em que este aluno seria treinado para repetir tarefas já desempenhadas antes por outros. O termo não deve ser confundido com o conceito de Atividade cunhado por Leontiev anos mais tarde, que constitui um conceito central na nossa pesquisa.
} 
consequência agradável, o sujeito estaria predisposto a repetir a experiência dando forma àquilo que ele classificou como lei do exercício. Os sujeitos que passassem por essas três fases teriam aprendido o conteúdo e se desenvolvido, ao mesmo tempo.

Para Thorndike, no entanto, a falta dos elementos idênticos à realidade, no Problema, contrariaria a lei da prontidão, já que o sujeito não estaria predisposto a conectar o estímulo e a resposta, por não reconhecer os elementos da situação; os Problemas sem esses elementos - como aqueles que remetem a números excessivamente grandes ou baseados em situações com pouca ou nenhuma possibilidade de ocorrer na "vida real" - seriam potenciais geradores de consequências desagradáveis (os erros) - contrariando a lei do efeito -, o que diminuiria a possibilidade de se colocar novamente em exercício - contrariando a lei do exercício.

Aprendizagem e desenvolvimento, nessa perspectiva, seriam processos únicos, pois o desenvolvimento seria meramente a aprendizagem "complexificada" pela repetição de exercícios. Nesse contexto Thorndike propõe sua percepção do que seria um bom Problema para as práticas de sala de aula. A proposta busca elevar os padrões para escolha dos Problemas segundo quatro critérios principais, a saber:

(1) versar sôbre situações que apresentam toda a probabilidade de ocorrer muitas vezes na vida real; (2) tratá-las do modo por que o seriam na vida prática; (3) apresentá-las sob uma feição nem muito mais difícil, nem muito mais fácil de entender do que seriam se a própria realidade as apresentasse aos sentidos do aluno; (4) despertar, de certo modo, o mesmo grau de interêsse que acompanha a resolução de problemas que se lhe deparam no curso real de suas ocupações (THORNDIKE, 1936, p. 154).

Questionando a exclusividade da condição psicobiológica do desenvolvimento e a caracterização de desenvolvimento e aprendizagem como processos idênticos, Vygotsky, em uma perspectiva materialista-dialética, apresenta considerações que sugerem a superação do entendimento do Problema como conexão entre o estudado e o "real". A superação ocorre no reconhecimento de que o Problema é, além de um importante método para o ensino e a aprendizagem, mediador e desencadeador desses processos. Em outras palavras, a partir de uma discussão considerando uma perspectiva histórico-cultural, entendemos que a mera apresentação de um Problema com elementos semelhantes àqueles verificados pelo estudante na "vida real" não seria suficiente para responder a uma demanda de organização do ensino pelo professor. 
De acordo com Vygotsky (2001), Thorndike refutava, adequadamente, a ideia segundo a qual o estudo da tabuada poderia influenciar a escolha correta de um casamento, ou o desenvolvimento da capacidade de compreender melhor uma piada. Aprender o conteúdo não teria, de fato, qualquer relação com estas capacidades. Mas, na ânsia de ir além, Thorndike teria errado ao ir para o outro extremo da análise ao defender que, não sendo possível que capacidades sem relação psicológica entre si desenvolvam-se a partir da mesma aprendizagem, então nenhuma aprendizagem poderia acarretar desenvolvimento para além do próprio conteúdo.

\begin{abstract}
Impõe-se perguntar o que dá a Thorndike o direito de estender as suas conclusões, efetivas apenas para combinações absurdas, a todo o campo da aprendizagem e do desenvolvimento da criança. Por que do fato de que nem tudo pode influenciar tudo ele conclui que nada influencia nada? Isto se deve à concepção teórica geral de Thorndike, segundo a qual não existem outras combinações da atividade da consciência além das combinações absurdas. (VYGOTSKY, 2001, p. 307).
\end{abstract}

De acordo com Vygotsky (2001), Thorndike entendia que a ideia de aprendizagem se confundia com o desenvolvimento em razão de ser meramente uma sucessão de vínculos associativos (conexões) e que o desenvolvimento se resumiria à quantidade de vínculos que o sujeito já teria realizado. Logo, aprender e se desenvolver seriam processos idênticos. Vygotsky indica que Thorndike pesquisou, experimentalmente, funções psicológicas mais restritas, especializadas e rudimentares, tendo ensinado os sujeitos participantes a distinguir os comprimentos relativos de linhas e buscando verificar se essa prática aumentava ou não a habilidade para distinguir as dimensões de ângulos. Naturalmente, de acordo com Vygotsky (2001, p. 308), Thorndike não encontrou nenhuma influência entre uma capacidade e outra. E nem poderia, já que não há qualquer relação entre as capacidades de verificar o tamanho de linhas e a medida de ângulos.

A ideia lançada por Thorndike, de que a seleção, a análise, a abstração, a generalização e a reflexão surgem como consequência direta dos vínculos estabelecidos entre elementos idênticos, percebidos sensorialmente da experiência cotidiana, é explicitamente refutada por Vygotsky, que defende que "os processos de formação de conceitos, como qualquer forma superior de atividade intelectual, não é uma forma inferior complexificada de modo exclusivamente quantitativo" (VYGOTSKY, 2001, p. 173 e 174). E é nesse contexto que podemos entender que um Problema, em perspectiva 
histórico-cultural, não se resume a um meio para colocar o aluno diante de uma possibilidade de conexão com elementos semelhantes àqueles percebidos das experiências cotidianas para, a partir do estímulo-resposta, proporcionar a aprendizagem - e, consequentemente, o desenvolvimento. Para Vygotsky (2001) o papel do Problema seria o de suscitar necessidades de apropriação da produção humana. Seria dessas necessidades que se originariam os motivos que colocariam o estudante em movimento para alcançar determinado o objeto.

Os termos - necessidade, motivo, objeto - destacados no parágrafo anterior nos remetem a conceitos específicos, em relação à compreensão comum, de sentido amplo deles mesmos. São conceitos basilares da Teoria da Atividade, proposta por Leontiev. $O$ termo atividade, de maneira especial, remete ao conceito específico e bem definido, que é central na análise que realizamos nesta pesquisa. A teoria encontra sua gênese nas obras dos principais psicólogos soviéticos do século $X X$, especialmente, nos estudos de Alexei Nikolaevich Leontiev (1903-1979). Leontiev formava ao lado dos companheiros Alexander Romanovich Luria (1902-1977) e Vygotsky um dos grupos mais profícuos da psicologia soviética.

De acordo com teoria da atividade, a apropriação da produção cultural da sociedade se dá pela atividade humana e produz resultados que superam sua mera adaptação à natureza. Isso é o que torna a espécie humana distinta, em termos de desenvolvimento, das outras espécies animais. Esta atividade é capaz de modificar a natureza em função da busca pela satisfação das necessidades do homem (LEONTIEV, 1978, p. 265). A atividade e a consciência, que promovem a intencionalidade de atuação do homem sobre o meio são conceitos fundamentais na THC, como indicamos anteriormente.

São as atividades humanas socialmente significadas, no sentido de serem produto da produção humana coletiva e histórica, que constituem o princípio explicativo do que entendemos por consciência, sendo esta construída do exterior para o interior, no âmbito das relações sociais (KOZULIN, 2002 apud RIGON, ASBAHR e MORETTI, 2016, p. 24). A caracterização da singularidade dos sujeitos, a partir da universalidade da produção humana, constitui a formação da consciência humana em sua relação com a atividade (Id., Ibid., p. 25). 
Para Leontiev, o desenvolvimento hereditário-biológico das espécies é lento e, por si só, não explica o estágio do desenvolvimento humano (LEONTIEV, 1978, p. 266) da mesma maneira que o desenvolvimento exclusivamente social não se sustenta diante da análise de outras espécies animais, que, ainda que inseridas no seio de comunidades humanas, não se desenvolvem tanto quanto os humanos. Assim, o desenvolvimento da espécie humana precisa ser inserido em um contexto, dialético, regido tanto por leis biológicas quanto por leis sociais (oriundas da própria produção histórica e cultural) (LEONTIEV, 1978, p. 162). O homem social se apropria da produção cultural da sociedade, ao mesmo tempo em que a produz.

São as necessidades que dão ao homem motivos para agir em busca de satisfazêlas. Os homens constroem habitações, roupas, máquinas e outros bens materiais para satisfazer suas necessidades, e o fazem porque a cultura demanda que se faça. Ao nascer, um indivíduo é inserido em uma sociedade já organizada e que demanda que tal indivíduo se aproprie daquilo que já foi produzido, ao mesmo tempo em que demanda novas produções para suprir as suas necessidades, que por sua vez se integrarão à produção humana naquela sociedade e será repassado para as gerações posteriores.

O motivo, oriundo da necessidade, faz o indivíduo agir rumo ao objeto. Quando o motivo que coloca o sujeito em movimento e o objeto alcançado coincidem exatamente com aquele almejado caracteriza-se a atividade. Assim, de acordo com Leontiev (1978), a atividade relaciona-se com a necessidade do sujeito. Verificamos aqui, a exemplo de Moretti (2014, p. 33), que "considerar ensino e aprendizagem pautados em problemas implica, na perspectiva histórico-cultural, na elaboração de situações desencadeadoras de aprendizagem que embutam, em si, a necessidade do conceito [matemático]".

Às vezes, no entanto, o motivo que coloca o sujeito em movimento não coincide exatamente com o objeto a ser alcançado. Essa situação define uma ação no contexto da atividade. A ação implica um motivo compreensível na atividade, que não coincide exatamente com seu objeto, mas que pode ser alterado para se tornar um motivo eficaz, este sim, coincidente com o objeto da atividade. Quando, por exemplo, o professor propõe um jogo, com o objetivo de que o aluno se aproprie de um conceito matemático, vencer o jogo é um motivo compreensível, enquanto a apropriação do conceito matemático seria um motivo eficaz. A ideia central é a de que, ao iniciar o movimento a 
partir do motivo compreensível, o estudante constituir novos sentidos sobre o objeto de modo que seus motivos iniciais para jogar se modifiquem.

Os termos "sentido" e "significado" que temos utilizado até aqui, também poderiam remeter, no senso comum, a uma grande variedade semântica, sendo às vezes, inclusive, compreendidos como sinônimos. É necessário, no entanto, destacar que, na perspectiva histórico-cultural, tais termos não devem ser compreendidos lato sensu ou como sinônimos. Essa distinção também se apoia no arcabouço teórico da THC, e nos ateremos a ela no subitem 2.1.2.

\subsubsection{Significação, Significados e Sentidos sobre Problemas.}

Aproximamos nossa compreensão de sentido e significado daquela proposta, inicialmente, por Vygotsky (2001) e consolidada, posteriormente, por Leontiev (1978), ambas levando em consideração aspectos históricos e culturais do desenvolvimento humano.

A princípio, cumpre destacar aspectos relacionados ao uso dos termos "sentido", "significação" e "significado". Tendo sido as obras de Vygotsky e Leontiev escritas, originalmente, em russo e traduzidas posteriormente para o português, os diversos tradutores dessas obras, seja a partir dos originais ou de outras traduções, tiveram como é razoável supor - distintas opções linguísticas, de modo que encontramos traduções que, por exemplo, remetem ao termo "significado" e outras que adotam "significação" para o mesmo contexto. Há pesquisadores brasileiros, como Piotto, Asbahr e Furlanetto (2017), por exemplo, que entendem que os termos "significado" e "significação" têm sido utilizados, no contexto das produções que remetem à Teoria Histórico-cultural - THC, como referências ao mesmo conceito. Nós, concordando com a interpretação dada por esses autores, adotaremos o termo "significação" como aquele que melhor remete à ideia de movimento de constituição de um conceito histórica e socialmente. Por "significado", entendemos que remete melhor ao produto de um processo de significação, todavia, é importante destacar que o processo de significação não está nunca concluído, de modo que devemos ter precaução ao nos remeter à ideia de "produto" do processo de significação. 
Vygotsky (2001) defende que as relações entre o pensamento e a linguagem se materializam na palavra, já que as interações sociais estabelecem, histórica e culturalmente, um sistema semiótico formado por signos e representado pelas palavras, que, por sua vez, estabelecem novas interações sociais, caracterizando uma relação dialética contínua entre o que se pensa e o que se fala. Em outras palavras, as interações sociais que relacionam palavra e signo, e que se dão em um processo histórico e cultural, é que conferem às palavras os seus respectivos significados. Para Vygotsky (2001, p. 398), "a palavra desprovida de significado não é palavra, é um som vazio".

Assim, a partir de Vygotsky (2001), a significação é uma produção social e coletiva, portanto, histórica e cultural. Uma analogia que podemos apresentar para compreender essa ideia é a seguinte: quando observamos, reconhecendo uma cultura judaico-cristã, alguém usando um anel de ouro, com certas características, no dedo anelar da mão esquerda, geralmente, relacionamos esse objeto nessas condições à palavra "aliança" e compreendemos que aquela pessoa é casada. Obviamente, pode ocorrer de a pessoa não ser casada e aquele ser simplesmente um ornamento. Todavia, a referida cultura produziu, historicamente (em um processo de significação), o significado de que aquele objeto, naquelas condições, representa uma união matrimonial e resumiu, ao longo do tempo, esse significado na palavra "aliança".

Já o sentido é fruto das experiências pessoais de cada sujeito no contexto da mesma cultura, durante o processo de significação. Dessa forma, de acordo com Vygotsky (2001), o sentido é "mais amplo" do que o significado, pois engloba todos os fatos psicológicos que a palavra nos remete, a partir de nossas experiências. É "uma formação dinâmica, fluida, complexa, que tem várias zonas de estabilidade variada. $\mathrm{O}$ significado é apenas uma dessas zonas do sentido que a palavra adquire no contexto de algum discurso e, ademais, uma zona mais estável, uniforme e exata" (VYGOTSKY, 2001, p. 465).

Sentidos e significados relacionam-se dialeticamente, de modo que significados sociais influenciam sentidos pessoais, ampliando-os, ao mesmo tempo que tais sentidos pessoais influenciam significados sociais, consolidando-os ou alterando-os. A distinção entre significação, significados e sentidos são ratificadas e complementadas por Leontiev (1978), como verificamos a seguir. 
Para Leontiev (1978) os conceitos de sentido e significação ganham contexto na compreensão dos processos de tomada de consciência, superando a ideia burguesa de que a consciência, que teria um conjunto particular de estruturas imutáveis, que existia por si mesma ou que algo pudesse "pertencer" à consciência para concluir que a consciência deve ser compreendida no contexto da atividade que humaniza o homem.

A consciência humana não é uma coisa imutável. Alguns dos seus traços característicos são, em dadas condições históricas concretas, progressivos, com perspectivas de desenvolvimento, outros são sobrevivências condenadas a desaparecer. Portanto, devemos considerar a consciência (o psiquismo) no seu devir e no seu desenvolvimento, na sua dependência essencial do modo de vida, que é determinado pelas relações sociais existentes e pelo lugar que o indivíduo considerado ocupa nestas relações. (LEONTIEV, 1978, p. 89)

Leontiev sustenta que a psicologia tradicional, especialmente a partir de Wundt, "considerava que as propriedades do psiquismo humano 'são em toda a parte e sempre idênticas', e que apenas o conteúdo da experiência e dos conhecimentos humanos se modifica" (LEONTIEV, 1978, p. 89) e, com isso, defende como aspecto a ser superado a não diferenciação entre os conceitos de "consciência" e "pensamento". Para Leontiev (1978), a evolução humana, os diversos modos de estar no mundo e a atividade do homem são fatores preponderantes para a constituição da consciência humana e o pensamento é apenas um dos aspectos dessa consciência, mas não ela como um todo.

Se as consciências fossem sempre e em toda parte idênticas, então, "com a abordagem tradicional da consciência da psicologia burguesa não podemos estudar aquilo que 'se encontra' na consciência ou aquilo que 'Ihe pertence', isto é, os fenômenos e processos psicológicos tomados à parte e as suas relações naturais" (LEONTIEV, 1978, p. 91). Por esse aspecto, os estudos da consciência sempre teriam a mesma estrutura e remeteriam às mesmas coisas. Mas Leontiev (1978) entende que a consciência não é algo imutável. Para ele o modo de vida humano e as interações entre o sujeito e o meio, a atividade desse sujeito, é que determinam a consciência. $O$ autor entende que há estruturas que se encontram na consciência, que lhe pertencem, e que são mutáveis em razão do meio e do tempo, e que precisam ser estudadas para a compreensão do desenvolvimento da consciência.

Uma analogia proposta por Leontiev para a compreensão dessa ideia é a seguinte: 
Suponhamos um homem caminhando na rua, absorvido numa conversa com um companheiro. Nos casos normais todo o seu comportamento corresponde perfeitamente ao que se passa à sua volta; retarda o passo num cruzamento, evita os peões que encontra pela frente, salta do passeio para a rua, sobe de novo para o passeio, etc. É evidente que ele percebe o seu meio circundante. Mas terá uma imagem consciente da situação da rua? Se estiver muito absorvido na conversa é possível que não. Podemos, neste caso, dizer que a situação da rua não está "presente" à sua consciência neste instante preciso. Mas eis que tem nitidamente consciência de que a casa para que se dirige com o seu interlocutor está diante dele. O quadro da rua e dos edifícios acaba de certa maneira de se descobrir no seu cérebro; está-lhe doravante "presente" (LEONTIEV, 1978, p. 92-93).

A realidade da rua está pressente na consciência do homem, mesmo que ele não esteja, necessariamente, pensando nisso o tempo todo. É essa aparente contradição que possibilita ao autor avançar na direção da apresentação dos conceitos de sentido e significação. O reflexo psíquico, no caso do exemplo, o ato de andar na rua, depende forçosamente da relação do sujeito com o objeto, ou seja, do seu sentido para o sujeito. Quando o homem alcança o objetivo (quando chega à casa a que se dirigia) a realidade se apresenta à sua consciência, ou seja, o sujeito reconhece os aspectos que envolvem a objetivação de suas ações, na significação dos objetos.

Leontiev (1978, p. 94) define que "significação é aquilo que em um objeto ou fenômeno se descobre objetivamente em um sistema de ligações, de interações e de relações objetivas. A significação é refletida e fixada na linguagem, o que the confere a sua estabilidade". Com isso o autor defende que a significação é o movimento histórico e social que nos permite relacionar a palavra e o objeto.

A significação é a generalização da realidade que é cristalizada e fixada num vetor sensível, ordinariamente a palavra ou a locução. É a forma ideal, espiritual da cristalização da experiência e da prática sociais da humanidade. A sua esfera das representações de uma sociedade, a sua ciência, a sua língua, existem enquanto sistemas de significações correspondentes. A significação pertence, portanto, antes de mais nada, ao mundo dos fenômenos objetivamente históricos (LEONTIEV, 1978, p. 94).

Dialeticamente, contudo, a significação existe também como fato da consciência individual. Leontiev (1978) entende que o homem percebe e pensa o mundo enquanto ser sócio-histórico e, por isso, possui como critério de análise da realidade à sua volta as representações e conhecimentos da sua época e da sua sociedade. Todavia, a sua consciência não se reduz à sua experiência individual, já que o modo de vida do homem não parte "do nada" para ir fazendo as suas próprias descobertas. Segundo o autor, no 
decurso da sua vida, "o homem assimila a experiência das gerações precedentes [e] este processo realiza-se precisamente sob a forma da aquisição das significações e na medida desta aquisição" (LEONTIEV, 1978, p. 94). A significação influencia, portanto, a forma sob a qual um homem assimila a experiência humana generalizada e refletida.

Para a compreensão da ideia a respeito do processo de significação, que se dá num contexto materialista histórico e social, Leontiev $(1978$, p. 95) faz uma analogia do campo dos conhecimentos geométricos:

[...] o que eu penso, compreendo e sei do triângulo, pode não coincidir perfeitamente com a significação [de] "triângulo" admitida na geometria moderna. Mas não é uma oposição fundamental. As significações não têm existência fora dos cérebros humanos concretos; não existe qualquer reino de significações independente e comparável ao mundo platônico das ideias. Por consequência, não podemos opor uma significação "geométrica", lógica e, em geral, objetiva, a esta mesma significação na consciência de um indivíduo enquanto significação psicológica particular. A diferença não é entre o lógico e o psicológico, mas entre o geral e o particular, o individual. Um conceito não deixa de ser conceito quando se torna o conceito de um indivíduo. [...] A realidade aparece ao homem na sua significação, mas de maneira particular. A significação mediatiza o reflexo do mundo pelo homem na medida em que ele tem consciência deste, isto é, na medida em que o seu reflexo do mundo se apoia na experiência da prática social e a integra" (LEONTIEV, 1978, p. 95).

Para Leontiev (1978) a significação está, geralmente, ausente da consciência, mas isso não é o mesmo que dizer que o sujeito "nunca tem consciência" sobre a significação. Da significação retratamos o percebido ou o pensado, mas ela própria não é conscientizada, não é pensada. Este fato psicológico, para Leontiev (1978), é fundamental, pois é o que possibilita a compreensão de que a significação "é o reflexo da realidade independentemente da relação individual ou pessoal do homem a esta. $O$ homem encontra um sistema de significações pronto, elaborado historicamente, e apropria-se dele tal como se apropria de um instrumento" (LEONTIEV, 1978, p. 96).

Admitida a significação como uma produção social e histórica, o grau de assimilação ou de transformação da consciência do sujeito depende do sentido subjetivo daquela significação. O sentido se estabelece no decurso do desenvolvimento da atividade que religa concretamente os animais ao seu meio e o reflexo psíquico decorrente dessa religação é indissociável da relação (LEONTIEV, 1978).

O sentido é aquilo que se apresenta à consciência do sujeito quando é criada uma relação objetiva (a significação) que se reflete no cérebro do homem. "A relação entre 
aquilo que o incita a agir [o motivo] e aquilo para o qual a sua ação se orienta como resultado imediato [o objeto]" (LEONTIEV, 1978, p. 96) é o sentido pessoal. O motivo, por sua vez, é o que impulsiona um movimento de satisfação de uma necessidade. E é também esse motivo que caracteriza o sentido pessoal do sujeito. Leontiev (1978, p. 97) conclui que "para encontrar o sentido pessoal devemos descobrir o motivo que the corresponde".

O sentido é, de acordo com Leontiev (1978), parte integrante do conteúdo da consciência e influencia a constituição dos significados sociais. A semelhança entre os conceitos de sentido e significado, originou na psicologia e na linguística o mal-entendido que culmina em uma não diferenciação entre eles, quer pelo fato de o sentido ser considerado como significado em função do contexto, quer por situações particulares em que ambos, até certo ponto, de fato, coincidem para sujeitos específicos. Ainda que o sentido ("sentido pessoal") e o significado pareçam fundidos devemos distinguir estes dois conceitos. Eles estão dialeticamente ligados um ao outro, mas a relação histórica é de precedência dos sentidos às significações, ou seja, "é o sentido que se exprime nas significações (como o motivo nos fins) e não a significação no sentido" (LEONTIEV, 1978, p. 98). A distinção entre os conceitos, para o autor, se evidencia em momentos como quando, por exemplo, temos a consciência perfeita de um acontecimento histórico, compreendemos a significação de uma data, mas isso não exclui o fato de que a mesma data possa ter vários sentidos para os diversos indivíduos.

Os sujeitos vão atribuindo sentidos às datas e, dentre esses sentidos, eventualmente, encontram-se também significados que foram histórica e culturalmente produto dos processos de significação. Por exemplo, o dia 25 de dezembro. Os povos de tradição cristã atribuem a essa data um significado: comemorar o nascimento de Jesus Cristo. Mas a história mostra que é pouco provável que Jesus tenha, de fato, nascido nessa data. Ao mesmo tempo, culturas de origem não cristã não conferem à data o mesmo significado que as culturas cristãs. Assim, um certo sujeito inserido em uma cultura cristã tende a pensar nessa comemoração quando fala sobre a data 25 de dezembro. Essa comemoração em 25 de dezembro constitui um sentido pessoal, mas esse sujeito pode também possuir outros sentidos sobre a mesma data, como um aniversário de um ente querido, um compromisso importante ou qualquer outro. 
De fato, os sentidos dos sujeitos precedem os significados, visto que, no movimento histórico, são os sentidos iniciais dos sujeitos que vão constituindo os significados. No exemplo que apresentamos, primeiro foi necessário que alguns sujeitos atribuíssem ao 25 de dezembro o sentido de comemorar o nascimento de Jesus e depois, no contexto histórico de culturas de tradição cristã, foi sendo fixada nessa data esse significado. Vemos também que, até certo ponto, realmente, um sentido de um sujeito pode também ser idêntico a um significado social. Quando um sujeito se apropria de um significado social de que 25 de dezembro significa comemorar o nascimento de Jesus, isso não impede que à mesma data ele atribua, também, outros sentidos (como o aniversário de um familiar). Os sentidos dos sujeitos que estão em atividades humanas, portanto, estão em constante movimento. O sentido de "comemorar o nascimento de Jesus" contribui para a constituição de um processo de significação relacionado à data de 25 de dezembro, sem, contudo, exprimir todos os sentidos de todos os sujeitos a respeito da data.

Quando se distingue sentido pessoal e significação propriamente dita, é indispensável sublinhar que esta distinção não concerne a totalidade do conteúdo refletido, mas unicamente aquilo para que está orientada a atividade do sujeito. Com efeito o sentido pessoal traduz precisamente a relação do sujeito com os fenômenos objetivos conscientizados (LEONTIEV, 1978, p. 98).

No nosso caso, o conceito de sentido e seu movimento ganham centralidade já em razão da nossa opção para composição do título deste trabalho. Ao anunciar que trataremos de acompanhar o movimento dos sentidos pessoais dos licenciandos sobre o conceito de Problema durante a formação inicial de professores de matemática, também já anunciamos nosso lugar de fala no contexto das pesquisas ligadas à teoria históricocultural.

Em linhas gerais, os licenciandos, já ao ingressarem nos cursos de formação de professores, possuem sentidos pessoais sobre o conceito de Problema. Esses sentidos, como vimos, decorrem das experiências desses mesmos alunos em uma cultura em que existe um processo de significação social de Problema, relacionado ao contexto de suas formações pessoais até a entrada na universidade. Contudo, é fundamental que possamos oportunizar novas experiências, próprias dos processos específicos de formação de professores de matemática, que permitam o movimento dos sentidos iniciais, a partir da identificação de contradições entre diferentes possíveis papéis 
atribuídos aos Problemas nas distintas práticas pedagógicas. Essas contradições remetem, por um lado, ao uso de Problemas como recurso de aplicação de definições e propriedades matemáticas já memorizadas e, por outro lado, como instrumento desencadeador na atividade orientadora de ensino e, portanto, como instrumento essencial das situações que potencializam a aprendizagem dos conceitos matemáticos e da própria organização do ensino, objeto de interesse da formação dos professores.

\subsubsection{Implicações teórico-metodológicas da THC}

A constatação de que os métodos aplicados pelos pesquisadores da sua época não seriam suficientes para a compreensão dos aspectos da aprendizagem humana que the interessavam, levou Vygotsky a concluir que era preciso "encontrar uma nova metodologia para a experimentação psicológica" que deveria possibilitar análise contextualizadas pela história humana (VYGOTSKY, 1991, p. 43).

Então, em um movimento de síntese, Vygotsky elegeu o materialismo históricodialético, proposto por Karl Marx, como a metodologia que melhor contribuía para ratificar a tese de que o homem se caracteriza como humano a partir "do entrelaçamento entre o aspecto individual, no sentido biológico, com o social, no sentido cultural" (RIGON, ASBAHR e MORETTI, 2016, p. 18). Em outras palavras, a força revolucionária do materialismo histórico-dialético reside na superação de que as coisas são aquilo que a consciência do homem determina que elas sejam (tese), como propunham idealistas, como também de que as coisas são o que são independentemente do que o homem possa pensar a respeito delas (antítese), como defendiam materialistas tradicionais à época, para o reconhecimento de que as coisas são, essencialmente, representações materiais da cultura humana historicamente constituída e da cultura acumulada que se reproduzem na consciência do homem que delas se apropria e é, por elas, apropriado (síntese).

O materialismo histórico-dialético, enquanto método, retira a ênfase da análise superficial de sujeitos ou de produtos finais, como fins em si mesmos, para direcionar as investigações à compreensão dos processos, cultural e historicamente constituídos. Essa conviç̧ão traz consigo a constatação de que o cerne do método histórico-cultural, como uma abordagem materialista dialética, é o desenvolvimento da psique em relação à 
apropriação da experiência humana acumulada, que, por sua vez, se dá a partir de um processo mediado consciente e intencional.

As concepções históricas e culturais da THC são, de fato, ratificadas pelo método marxista. O Homem supera a mera adaptação passiva à natureza circundante, transformando-a, já que "por meio de sua atividade, [o homem] altera as formas das matérias naturais de um modo que lhe é útil" (MARX, 2017, p.146). Isso é o que caracteriza o trabalho. E é isso o que humaniza o homem.

Uma aranha executa operações semelhantes às do tecelão e uma abelha envergonha muitos arquitetos com a estrutura de sua colmeia. Porém, o que desde o início distingue o pior arquiteto da melhor abelha é o fato de que o primeiro tem a colmeia em sua mente antes de construí-la com a cera. No final do processo de trabalho chega-se a um resultado que já estava presente na representação do trabalhador no início do processo, ou seja, um resultado que já existia idealmente. Isso não significa que ele se limite a uma alteração da forma do elemento natural; ele realiza neste último, ao mesmo tempo, a finalidade pretendida, que, como ele bem sabe, determina o modo de sua atividade com a força de uma lei, à qual ele tem de subordinar sua vontade. (MARX, 2017, p. 255256)

Essa capacidade, tipicamente humana, de reproduzir mentalmente uma materialidade não presente aos sentidos é o que nos permite a organização e o planejamento.

\begin{abstract}
Os instrumentos físicos (objetos) e simbólicos (linguagem) objetivam-se como um terceiro elemento, que se torna o mediador entre o homem e a natureza. Tal artefato inexiste entre os demais animais. Por isso, afirma-se que as ações humanas são mediadas. Nelas há planejamento, já que muitas delas não satisfazem diretamente uma necessidade, são apenas meios para se alcançar uma finalidade, isto é, além de mediadas as ações humanas são intencionais. A possibilidade de planejamento das ações e o uso adequado de instrumentos mediadores envolvem a participação do sujeito em uma coletividade, na qual o sentido e o significado das ações são partilhados. Ou seja, a ação humana é mediada, intencional e também coletiva (MOURA, SFORNI e ARAÚJO, 2011, p. 40 , grifo no original).
\end{abstract}

Para Vygotsky, é necessário considerar a experiência histórica, entendida como a assimilação das experiências acumuladas pelas gerações anteriores; a experiência social, chamando a atenção para a produção coletiva de cultura e para os processos de interações sociais; e a capacidade de atuar sobre o meio, já que o homem não se adapta, simplesmente, ao ambiente ao seu redor, mas o modifica para satisfazer suas necessidades, como defendia Marx (2017). Essa atuação sobre o meio se dá pela 
reprodução, no ambiente, de um processo que antes estava em sua mente (TEIXEIRA, 2005).

Em consonância com essa compreensão de desenvolvimento da psique a partir das experiências sociais e pessoais, torna-se necessário "desvelar a essência dos fenômenos psicológicos, suas leis de transformação, suas características qualitativas e quantitativas, sua causalidade, e criar as categorias e conceitos que Ihes são próprios" (TEIXEIRA, 2005, p. 36). De acordo com Martins (2006), o conhecimento da essência do fenômeno não é perceptível desde o princípio, mas sim em uma dimensão dialética, a partir de contradições internas, apropriação do desenvolvimento lógico-histórico e do pensamento teórico sobre o fenômeno.

Para o materialismo histórico dialético, o mundo empírico representa apenas a manifestação fenomênica da realidade em suas definibilidades exteriores. Os fenômenos imediatamente perceptíveis, ou seja, as representações primárias decorrentes de suas projeções na consciência dos homens, desenvolvem- se à superfície da essência do próprio fenômeno (MARTINS, 2006, p. 10).

Concretamente, Vygotsky (1991) apresenta três princípios que formam a base do método de análise do desenvolvimento das funções psíquicas superiores no contexto da THC: a análise de processos e não de objetos (do fenômeno); a explicação versus a descrição; e o problema do "comportamento fossilizado".

O primeiro princípio, de acordo com Vygotsky (1991), remete à superação da análise de um objeto pela análise de um processo. Para isso, Vygotsky (1991) defende a necessidade de uma análise a partir de uma exposição dinâmica dos principais pontos constituintes da história dos processos. Com isso, a proposta vygotskiana passa pela necessária reprodução do movimento que culmina na produção histórica do conceito. Nesse sentido, é importante destacar que não se trata, necessariamente, da reprodução da história factual, mas de promover um movimento em que a essência dos processos históricos esteja em evidência. No caso da aprendizagem da matemática

Isso implica que a história da matemática que envolve o problema desencadeador não é a história factual, mas sim aquela que está impregnada no conceito ao se considerar que esse conceito objetiva uma necessidade humana colocada historicamente. Assim, por exemplo, o professor pode propor aos alunos um problema envolvendo a representação de um movimento de quantidades variáveis sem falar, necessariamente, sobre Leibniz, Euler ou Fourier. As informações factuais podem contribuir a posteriori, dependendo da série na qual se está trabalhando, para que os alunos reconheçam o processo 
histórico de construção dos conceitos por meio do qual as contribuições dos indivíduos particulares vão sendo incorporadas e superadas por outros, num processo social de produção de conhecimento (MORETTI, 2007, p. 98-99).

É no contexto do desenvolvimento das Funções Psicológicas Superiores e da investigação acerca do movimento histórico e cultural do conhecimento que o Problema, na perspectiva histórico-cultural, assume um papel de destaque. Vygotsky (2001, p. 171) defende que "é precisamente com o auxílio dos problemas propostos, da necessidade que surge e é estimulada, dos objetivos colocados perante o adolescente que o meio social circundante o motiva e o leva a dar esse passo decisivo no desenvolvimento do seu pensamento".

O segundo princípio, a explicação versus a descrição, coloca em destaque a crítica de Vygotsky a processos analíticos que tendem a descrever características superficiais do fenômeno (fenotípicas), sensoriais, cuja superação não prescinde de uma análise explicativa do fenômeno, como um todo. Essa superação pressupõe, conforme Vygotsky (1991), descortinar todos os aspectos essenciais desse fenômeno a partir de sua origem (genotípica). O processo de descrição é parte da análise explicativa, mas não o define.

No nosso caso específico, uma abordagem fenotípica se restringiria a realizar e descrever o experimento formativo, como um fim em si mesmo e considerando diretamente as manifestações e aparências comuns do fenômeno, podendo com isso apresentar aspectos dos sentidos dos licenciandos sobre Problema que nada tivessem a ver com o fenômeno da formação de professores que o contextualiza. Explicar o fenômeno (ao invés de apenas descrevê-lo) pressupõe uma análise do processo que evidencia o movimento dialético, a partir das contradições que lhe são inerentes, onde se "manifesta a unidade entre teoria e prática uma vez que a teoria que subsidia a investigação é continuamente revisitada e ressignificada de forma mediada pela prática" (MORETTI, et al., 2017, p. 33).

O terceiro princípio apresentado por Vygotsky, o problema do "comportamento fossilizado", diz respeito ao fato de que

[...] defrontamo-nos frequentemente com processos que esmaeceram ao longo do tempo, isto é, processos que passaram através de um estágio bastante longo do desenvolvimento histórico e tornaram-se fossilizados. Essas formas fossilizadas de comportamento são mais facilmente observadas nos assim chamados processos psicológicos automatizados ou mecanizados, os quais, dadas as suas origens remotas, estão agora sendo repetidos pela enésima vez e tornaram-se mecanizados. Eles perderam sua aparência original, e a sua aparência externa 
nada nos diz sobre a sua natureza interna. Seu caráter automático cria grandes dificuldades para a análise psicológica (VYGOTSKY, 1991, p. 45).

Esses três princípios permitem, na THC, uma análise do desenvolvimento das funções psíquicas superiores, no contexto da atividade humana. Todavia, não de maneira direta. O modo como cada sujeito se relaciona com aquilo que é produzido pela espécie ocorre de maneiras particulares. Dito de outra forma, as relações entre a universalidade (a produção humana) e as singularidades (a apropriação e produção de indivíduos) são mediadas por relações particulares.

De acordo com Oliveira (2001) as pessoas, no decurso de suas atividades realizadas em grupos singulares vão, historicamente, constituindo significações. A significação, no entanto, não é algo disponível na mente de cada sujeito já que ela vai se constituindo no contexto universal. No entanto, em determinadas circunstâncias, os significados universais também subsidiam significados singulares, pois estes são produtos de atividades coletivas, em contextos singulares, constituídos a partir dos sentidos pessoais de cada sujeito do grupo. As circunstâncias que possibilitam a relação dialética entre o singular e o universal constituem o particular.

Dessa forma, nesse movimento, no contexto singular em que cada indivíduo exerce sua atividade, ao mesmo tempo em que se apropria de significados universais produzidos anteriormente, o sujeito vai, sob circunstâncias adequadas (particulares), estabelecendo ou modificando os próprios sentidos e participando da produção de novos significados singulares. Esses significados singulares vão, por sua vez, subsidiando o processo de significação universal. Da mesma forma, os significados universais possibilitam que aqueles significados singulares de cada grupo não precisem começar "do zero" a cada nova geração, já que o universal vai se constituindo e se modificando historicamente. Assim, são nos contextos singular e universal da atividade humana que se produzem os sentidos pessoais de cada sujeito, mediados por situações particulares que medeiam a relação dialética entre tais sentidos pessoais e o processo histórico de significação. A figura 4 ilustra esse movimento e é fundamental para a compreensão do movimento formativo que acompanhamos: 
Figura 4: Dialética Singular-Particular-Universal

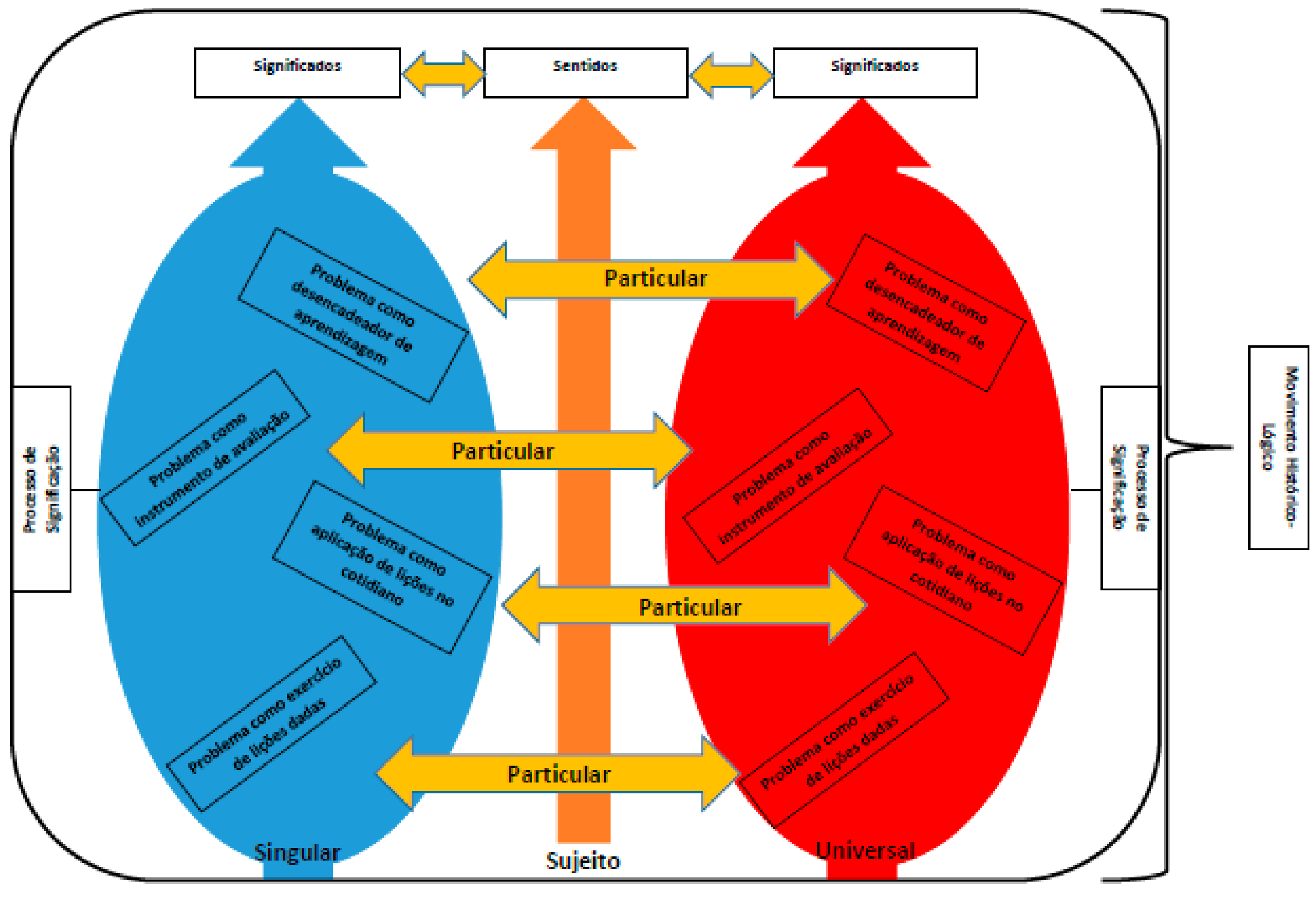

Fonte: Elaborada pelo autor 
Ainda nesse contexto da relação dialética entre o singular-particular-universal, em relação à atribuição de sentidos e a produção de significados, consideramos importante destacar a não linearidade do movimento. Com isso chamamos a atenção para as múltiplas singularidades envolvidas no processo de significação.

Dessa forma, no nosso caso, o grupo singular de licenciandos se relaciona com o processo universal de significação relativo ao conceito de Problema por meio do experimento formativo, que constitui o particular. É nele que evidenciamos a intencionalidade da organização de uma formação para o desenvolvimento da aprendizagem da docência em uma perspectiva histórico-cultural, destacando o Problema como desencadeador de aprendizagem, no qual buscamos acompanhar o movimento dos sentidos pessoais sobre o conceito de Problema nesse contexto singular, compreendendo as maneiras pelas quais significados singulares e universais se relacionam dialeticamente com esse movimento dos sentidos.

\subsection{Indícios de Sentidos sobre o papel do Problema no ensino de matemática: o que dizem algumas publicações?}

Feitas essas considerações sobre a THC, trataremos, neste subcapítulo, da apresentação de aspectos que possibilitem reconhecer um movimento histórico de produção do conceito de Problema, considerando que os aspectos presentes na cultura escolar, relacionados ao papel do Problema na organização do ensino, são resultado dessa produção histórica e, portanto, indiciam sentidos pessoais de pesquisadores e licenciandos, bem como fazem parte do processo de significação social universal do conceito de Problema.

Inicialmente, verificamos que os Problemas fazem parte da História da Matemática desde tempos imemoriais. A presença deles em documentos históricos antigos parece ser entendida por alguns pesquisadores como indício da importância destes para as práticas educativas desde tempos igualmente longínquos. Onuchic (2008), por exemplo, aponta que "problemas de matemática têm ocupado um lugar central no currículo da matemática Escolar desde a Antiguidade" (ONUCHIC, 2008, p. 1). Com isto, a autora propõe que os Problemas tiveram importância fundamental no desenvolvimento da matemática e que este fato teria sido apropriado pela matemática escolar de modo que os Problemas teriam passado a ocupar lugar de destaque nas práticas pedagógicas ao 
mesmo tempo em que a própria matemática se desenvolvia. De acordo com Onuchic (2008) "registros de problemas matemáticos são encontrados na história antiga egípcia, chinesa, babilônica e grega" (ONUCHIC, 2008, p. 1). Entendemos que as considerações de Onuchic parecem aproximar a presença dos Problemas na História da Matemática da relevância de tais Problemas para o ensino de matemática.

Similarmente, D’Ambrósio (2008) defende que "a resolução de problemas sempre foi considerada uma parte importante do ensino de matemática" (D'AMBRÓSIO, 2008, p. 1, grifo nosso) e que a preocupação sobre a forma como a resolução de Problemas é ensinada nas escolas sempre esteve presente na matemática escolar. A autora também faz referência à teoria, difundida no século XIX, segundo a qual os Problemas seriam exercícios para o desenvolvimento do cérebro, num movimento de disciplina mental, analogamente ao benefício muscular do exercício físico. Segundo D’Ambrósio (2008) o pressuposto dessa teoria seria o de exercitar as lições ensinadas previamente, de modo que um Problema seria qualquer situação que colocasse o aluno diante da oportunidade de exercitar tais lições. Para a autora, é possível perceber essas ideias nas práticas de professores até os dias atuais.

Indo de encontro à ideia de que os Problemas na matemática e na educação matemática sempre convergiram para o mesmo ponto, Stanic e Kilpatrick (1989) apontam que a importância dos Problemas na matemática contrasta com a pouca relevância destes nos currículos escolares. Esses autores destacam a obra de Pólya, sobretudo o livro "How to Solve It", de 1945, como ponto de destaque na atribuição de relevância dos Problemas para as práticas de ensino de matemática. De acordo com Stanic e Kilpatrick, "só recentemente apareceram educadores matemáticos aceitando a ideia de que o desenvolvimento da capacidade de resolução de problemas merece especial atenção" (STANIC e KILPATRICK, 1989, p. 1). Ainda de acordo com os autores, encontram-se Problemas em livros didáticos de matemática dos séculos $\mathrm{XIX}$ e $X X$, o que indicaria a presença dos Problemas nas aulas de matemática, contudo, segundo suas interpretações, era assumida uma visão muito estreita da aprendizagem da resolução de Problemas. Para eles, ensinar a resolução de Problemas significava apresentar Problemas e, talvez, incluir um exemplo de uma solução técnica específica. Também verificamos sentidos pessoais atuais que estão em consonância com esta conclusão de 
Stanic e Kilpatrick, e que constituem o que chamamos de "Problemas padrão" que pressupõem Problemas que remetem a modelos a serem reproduzidos.

De fato, as contribuições de Pólya recebem grande destaque nos discursos acerca na caracterização de Problemas e, sobretudo, de aspectos de sua resolução, no campo da Educação Matemática. O livro How to solve it foi traduzido no Brasil sob o título "A Arte de Resolver Problemas". No livro, Pólya coloca em pauta a necessidade de um processo de ensino voltado específica e especialmente para os processos de resolução de Problemas. A importância atribuída à obra de Pólya foi tamanha que, de acordo com D’Ambrósio (2008), houve uma injusta redução da sua obra ao processo heurístico que ele apresenta como sugestão para organização dos processos resolução de Problemas.

O processo heurístico de Pólya (1995, p. 86) "procura compreender o processo solucionador de problemas, particularmente as operações mentais, típicas desse processo, que tenham utilidade". O processo heurístico de Pólya, contudo, chegou aos nossos dias "resumido" nos passos que ele propôs para a resolução de um Problema: Compreender o problema, localizar o que se pede (a incógnita), traçar um plano de resolução, executar o plano de resolução e examinar a solução (conferir a resposta).

Destacamos que a obra de Pólya é, geralmente, interpretada a partir de uma perspectiva segundo a qual haveria a necessidade de se ensinar, na matemática escolar, a resolver qualquer Problema. Uma interpretação das propostas de Pólya, inclusive, leva a certas práticas que pressupõem a resolução de Problemas como um aspecto isolado no processo de aprendizagem, como se a resolução de Problemas fosse um conteúdo do currículo, assim como funções, equações, etc. Não há dúvidas de que tal não era o objetivo de Pólya (STANIC e KILPATRICK, 1989).

Pólya não tinha como público-alvo específico os professores de matemática. Sua proposta era a de tratar de aspectos da resolução de qualquer Problema por qualquer pessoa. Acreditamos ser este um fator primordial para as interpretações distorcidas de sua obra, que se seguiram às suas publicações. Afinal, de fato, é tentador que ao identificarmos esse objetivo (qualquer pessoa aprender a resolver qualquer Problema) busquemos em seus textos "receitas" que contribuam para resolvermos qualquer Problema. Essa interpretação, no entanto, desloca do sujeito a ação de resolver o Problema, depositando-a em algum algoritmo. Com efeito, as características artificiais 
que permeiam uma ampla gama de Problemas escolares, permitem a criação de "algoritmos" de resolução "eficientes". Todavia, apenas são eficientes em movimentos em que o propósito seja a resolução em si e não a aprendizagem e para Problemas que possam ser resolvidos pela mera reprodução de algum algoritmo, ou seja, que constituam uma aplicação de algo já sabido.

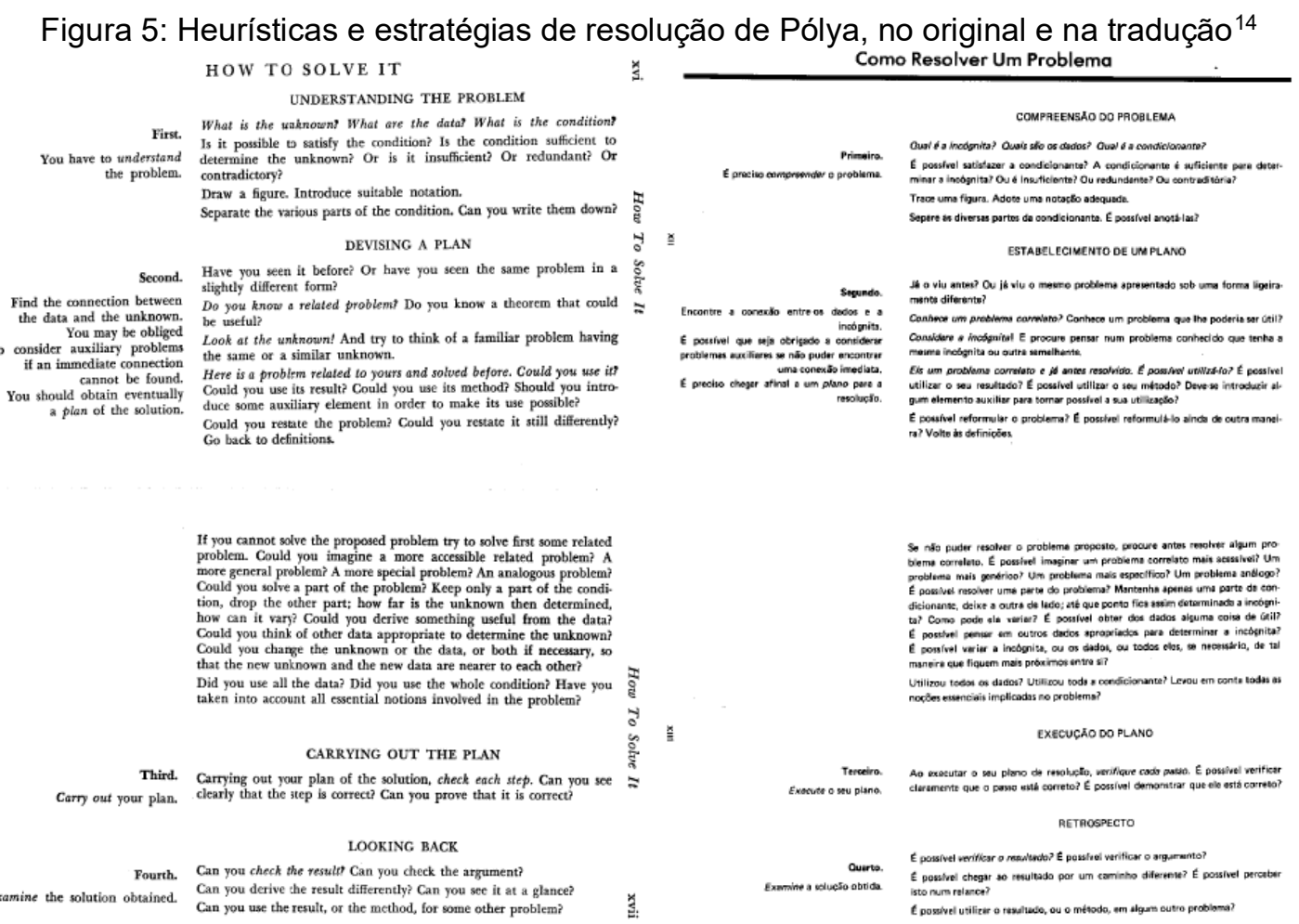

Fonte: Digitalizado das obras "How to solve it" (1944) e "A arte de resolver problemas" (1995), pelo autor.

Essa eventual busca por procedimentos receituários para resolução de qualquer Problema, na obra de Pólya, é fomentada pela apresentação resumida dos procedimentos heurísticos de Pólya, bem como das principais estratégias de resolução que o autor propõe no decorrer de seu principal livro. A superficialidade que criticamos no movimento de apropriação dos conceitos matemáticos, é aplicável também nesse caso, de modo que, entendemos, resumir a obra de Pólya a tais procedimentos constitui

\footnotetext{
${ }^{14}$ As imagens são ilustrativas com fins de comparação das sínteses em cada obra (original e tradução). 0 conteúdo de ambas está apresentado, de maneira legível, mais adiante.
} 
uma análise muito superficial de suas proposições. O quadro 2 apresenta o conteúdo desse resumo.

Quadro 2: Heurísticas e estratégias de resolução de Pólya

\begin{tabular}{|c|c|}
\hline \multicolumn{2}{|c|}{ Compreensão do Problema } \\
\hline $\begin{array}{l}\text { Primeiro. } \\
\text { É preciso compreender o problema. }\end{array}$ & $\begin{array}{l}\text { Qual é a incógnita? Quais são os dados? Dual é a } \\
\text { condicionante? É possível satisfazer a } \\
\text { condicionante? A condicionante é suficiente para } \\
\text { determinar a incógnita? Ou é insuficiente? Ou } \\
\text { redundante? Ou contraditória? } \\
\text { Trace uma figura. Adote uma notação adequada. } \\
\text { Separe as diversas partes da condicionante. É } \\
\text { possível anotá-las? }\end{array}$ \\
\hline \multicolumn{2}{|c|}{ Estabelecimento de um Plano } \\
\hline $\begin{array}{l}\text { Segundo. } \\
\text { Encontre a conexão entre os dados e a incógnita. } \\
\text { É possível que seja obrigado a considerar } \\
\text { problemas auxiliares se não puder encontrar uma } \\
\text { conexão imediata. } \\
\text { É preciso chegar afinal a um plano para a } \\
\text { resolução. }\end{array}$ & $\begin{array}{l}\text { Já o viu antes? Ou já viu o mesmo problema } \\
\text { apresentado sob uma forma ligeiramente } \\
\text { diferente? Conhece um problema correlato? } \\
\text { Conhece um problema que lhe poderia ser útil? } \\
\text { Considere a incógnita! E procure pensar num } \\
\text { problema conhecido que tenha a mesma incógnita } \\
\text { ou outra semelhante. } \\
\text { Eis um problema correlato e já antes resolvido. É } \\
\text { passível utilizá-lo? É possível utilizar o seu } \\
\text { resultado? É possível utilizar o seu método? Deve- } \\
\text { se introduzir algum elemento auxiliar para tornar } \\
\text { possível a sua utilização? É possível reformular o } \\
\text { problema? É possível reformulá-lo ainda de outra } \\
\text { maneira? } \\
\text { Volte às definições. } \\
\text { Se não puder resolver o problema proposto, } \\
\text { procure antes resolver algum problema correlato. } \\
\text { É possível imaginar um problema correlato mais } \\
\text { acessível? Um problema mais genérico? Um } \\
\text { problema mais específico? Um problema análogo? } \\
\text { É possível resolver uma parte do problema? } \\
\text { Mantenha apenas uma parte da condicionante, } \\
\text { deixe a outra de lado; até que ponto fica assim } \\
\text { determinada a incógnita? Como pode ela variar? É } \\
\text { possível obter dos dados alguma coisa de útil? } \\
\text { É possível pensar em outros dados apropriados } \\
\text { para determinar a incógnita? } \\
\text { É possível variar a incógnita, ou os dados, ou todos } \\
\text { eles, se necessário, de tal maneira que fiquem } \\
\text { mais próximos entre si? }\end{array}$ \\
\hline
\end{tabular}




\begin{tabular}{|l|l|}
\hline \multicolumn{1}{|c|}{ Execução do Plano } \\
\hline $\begin{array}{l}\text { Terceiro. } \\
\text { Execute o seu plano. }\end{array}$ & $\begin{array}{l}\text { Utilizou todos os dados? Utilizou toda a } \\
\text { condicionante? Levou em conta todas as noções } \\
\text { essenciais implicadas no problema? }\end{array}$ \\
\hline $\begin{array}{l}\text { Quarto. } \\
\text { Examine a solução obtida. } \\
\text { petrosso está correto? É possível demonstrar que ele } \\
\text { está correto? }\end{array}$ \\
\hline \multicolumn{1}{|c|}{$\begin{array}{l}\text { É possível verificar o resultado? É possível verificar } \\
\text { o argumento? } \\
\text { É possível chegar ao resultado por um caminho } \\
\text { diferente? É possível perceber isto num relance? } \\
\text { É possível utilizar o resultado, ou o método, em } \\
\text { algum outro problema? }\end{array}$} \\
\hline
\end{tabular}

Fonte: PÓLYA (1995, p. XII e XIII)

O entendimento de que tais proposições se constituiriam como regras de resolução levou estudiosos dos Problemas e dos aspectos de sua resolução nos processos de ensino e aprendizagem, posteriormente, a apresentarem suas críticas às propostas de Pólya, atribuindo um caráter excessivamente generalista às heurísticas. Em entrevista a Guimarães (2011), Jeremy Kilpatrick, que foi aluno e assistente de Pólya, entende que as heurísticas de Pólya

[...] são boas sugestões. Elas são úteis [...]. Eu acho que elas são difíceis de aprender. Quero dizer, uma das questões que surgem mais tarde é que...Alan Schoenfeld argumenta que estas [sugestões] são gerais demais, que são muito difíceis de ensinar e que não são específicas o suficiente para... programar uma máquina para resolver problemas. Mas eu diria que, se você vir exemplos suficientes de como essas heurísticas funcionam, você gradualmente irá adotálas em sua própria solução de problemas. E você pode ver ... você pode ver como elas operariam, e Pólya dá muitos exemplos disso. Na verdade, o Mathematical Discovery inclui ainda mais exemplos - o livro [de Pólya] Mathematical Discovery - e aprendi tudo sobre ele mais tarde. Mas mesmo com How to Solve It, que tem... menos exemplos do tipo de problemas [de] matemática secundária, até mesmo How to Solve It dá muito bons conselhos sobre como pensar a respeito problemas ${ }^{15}$. (GUIMARÃES, 2011, p. 72, tradução nossa)

${ }^{15}$ Tradução livre para o trecho: Because they are good suggestions. They are useful if you, if you.. I think they are difficult to learn. I mean, one of the issues that comes up later is [that] ... Alan Schoenfeld argues that these [suggestions] are too general, that they are too difficult to teach, and that they are not specific enough for ... programming a machine to solve problems. But I would argue that if you see enough examples of how these heuristics work, you gradually come to adopt them in your own problem solving. And you can see ... you can see how they would operate, and Pólya gives a lot of examples of that. Actually, Mathematical Discovery includes even more examples — [Pólya's] book Mathematical Discovery — and I 
Kilpatrick defende que as proposições de Pólya para a resolução de Problemas são sugestões que admitem afastamentos e aproximações, caso a caso, pois não seria intenção deste "programar" máquinas para o trabalho de solução, mas sim nortear a aprendizagem sobre como resolver Problemas. O próprio Kilpatrick, juntamente com Stanic (KILPATRICK e STANIC, 1989), entendem Pólya como precursor de um entendimento que admite a capacidade de resolver Problemas como "arte", tal qual a escrita de poesias ou a composição de canções.

De qualquer forma, a grande ênfase atribuída aos trabalhos de Pólya em relação à importância da aprendizagem da resolução de Problemas, culminaram na disseminação de ideias - portanto, na conformação potencial de sentidos - sobre o próprio Problema. No Brasil, a obra de Pólya influenciou diversos autores entusiastas da resolução de Problemas como método. Dentre esses autores, Luiz Roberto Dante escreveu o livro "Didática da Resolução de Problemas de matemática", em que se propõe a tratar do Problema não apenas a partir das propostas polyanas para resolução, mas, indo além, apresenta-se como indicativo "da forma adequada de propor problemas e do modo de envolver os alunos em sua resolução" (DANTE, 1998, p. 9, grifo nosso).

Já na apresentação, o autor propõe uma definição sobre o que seria um problema, definindo que seria "qualquer situação que exija o pensar do aluno para solucioná-la" (DANTE, 1998, p. 9). E indica o Problema como uma categoria dos problemas que, por sua vez, "exija a maneira matemática de pensar e conhecimentos matemáticos para solucioná-la" (idem, ibidem, p. 10). Já indicamos que, concordando com Saviani (2000), uma situação que exija o pensar para ser resolvida, por si só, não caracteriza um problema, ainda que sua resposta seja desconhecida, pois a necessidade de pensar não implica na necessidade de se resolver. Um Problema, segundo entendemos, é a representação de uma situação cuja resposta se desconhece e necessita-se conhecer.

Anunciando apresentar objetivos para o uso de Problemas em sala de aula, Dante (1998) entende que estes deveriam: fazer o aluno pensar produtivamente; desenvolver o raciocínio do aluno; ensinar o aluno a enfrentar situações novas; dar ao aluno a

learned all about that later. But even with How to Solve It, which has ... fewer examples of the kind of problems [from] secondary mathematics, even How to Solve It gives a lot of good advice on ways of how to think about problems. 
oportunidade de se envolver com as aplicações da matemática; tornar as aulas de matemática mais interessantes e desafiadoras; equipar o aluno com estratégias para resolver Problemas; e dar boa base matemática às pessoas. Tais objetivos parecem ser indícios de sentidos pessoais que compreendem os Problemas como instrumentos de aplicação do conteúdo matemático ensinado e de que a capacidade de resolver tais Problemas seja condição necessária e suficiente para resolver quaisquer espécies de problemas na vida do aluno.

No segundo capítulo do livro, Dante apresenta "os vários tipos de Problemas", classificando os Problemas conforme os processos a serem aplicados em sua resolução. A classificação é o recurso ao qual lançam mão, de modo geral, os estudantes quando submetidos ao desafio de se resolver um Problema. O aluno, nessa situação, recorre a um conjunto prévio de conhecimentos já adquiridos e verifica quais procedimentos inerentes a tais conhecimentos (muitas vezes decorados a partir de fórmulas, algoritmos ou propriedades) aplicam-se para apresentar a resposta esperada. Dessa forma, responder a uma questão não implica, necessariamente, estar pensando a respeito da situação proposta, como o próprio autor sugere, mas apenas estar classificando a questão segundo um conjunto de conhecimentos prévios. Da mesma forma, a classificação dos Problemas por "tipos", para além da subjetividade e da arbitrariedade da própria classificação, sugere que o papel do Problema na organização da prática docente passa pela estratégia de solução que se deseja "treinar" e não pela necessidade de apropriação conceitual que se supõe seja objeto da referida prática.

Apesar da defesa de que seria necessário "fazer uma clara distinção entre o que é um exercício e o que é um problema" (DANTE, 1998, p. 43) e que "ensinar a resolver problemas é uma tarefa mais difícil do que ensinar conceitos, habilidades e algoritmos matemáticos" (idem, ibidem, p. 42), os indícios de sentidos que podemos inferir a partir do livro vão ao encontro do entendimento de que o papel dos Problemas é o de oportunizar o exercício de técnicas que possam ser adotadas para a solução de quaisquer Problemas e que, por consequência, seria papel do professor apresentar uma gama de Problemas tais que oportunizassem a aplicação de tais técnicas de solução. Nesse mesmo sentido, ao final da obra, Dante (1998) apresenta uma coleção com cento e quatorze Problemas sugeridos e as respectivas soluções e comentários que tendem a 
reforçar as ideias envolvidas nas técnicas a serem aplicadas para a resolução. O conceito matemático envolvido em tais soluções é sempre secundário, sendo razoável supor que a proposta didática apresentada pelo autor admite que tais conceitos são conhecidos previamente, e, como isso, que o Problema é aplicação e não método, em que assumiria papel central na organização da prática pedagógica.

Dessa forma, ao que parece, o sentido impregnado em Dante (1998) é aquele segundo o qual o Problema é finalidade, ou seja, o aluno aprende matemática para resolver Problemas, e não método, no qual o aluno vai aprendendo matemática à medida em que vai resolvendo os Problemas.

O mesmo autor, em outra obra intitulada "Formulação e Resolução de Problemas de matemática: Teoria e Prática", apresenta considerações acerca da "adequada" formulação de Problemas a serem apresentados nas práticas docentes nas escolas. Nesse livro, porém, podemos inferir indícios de sentidos diferentes a respeito do papel do Problema nas séries iniciais e na formação de professores. Ainda que seja possível verificar o recurso a exemplos similares e às mesmas classificações já consagradas na obra que apresentamos anteriormente, notabiliza-se a constituição de diferenças em relação à compreensão do que seriam problemas e Problemas.

Figura 6: llustrações da definição de Problema por Dante
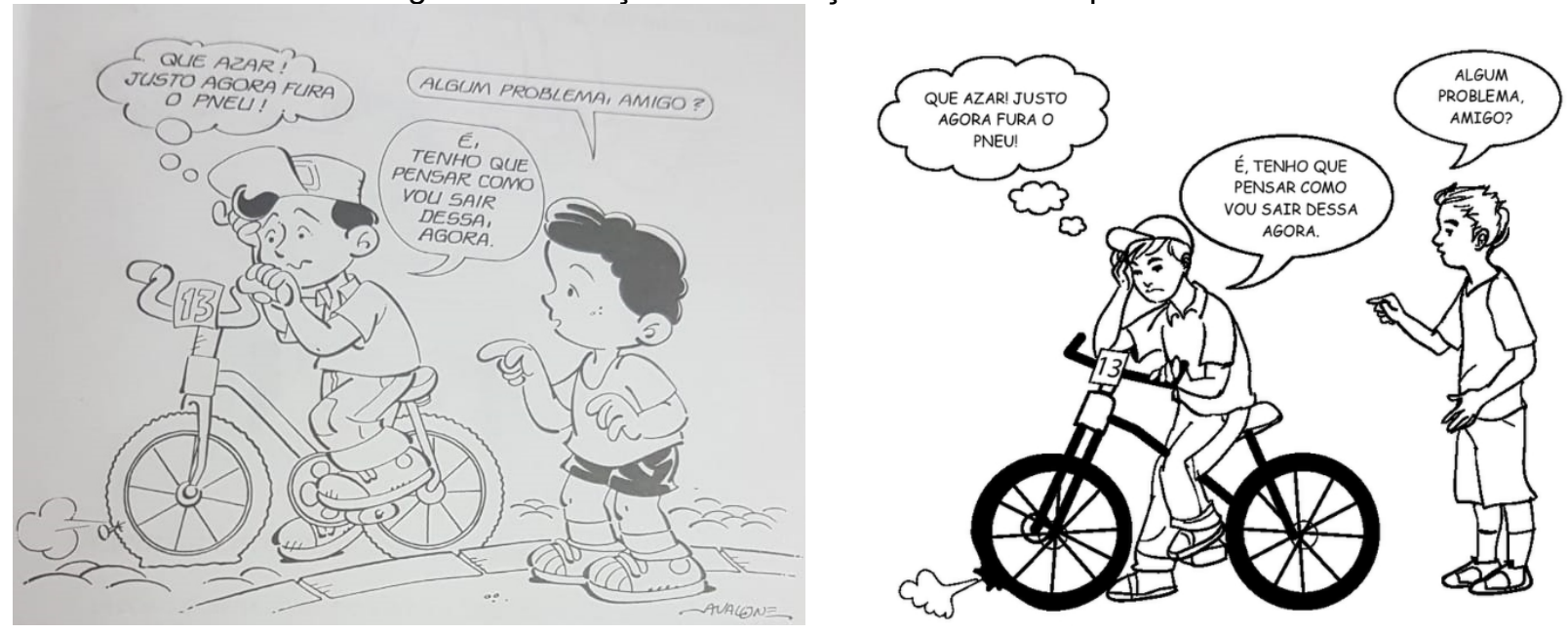

Fonte: à esquerda Dante (1998, p. 9) e à direita Dante (2009, p. 11)

Na versão de 2009, Dante complementa a definição apresentada anteriormente, afirmando que problema é uma noção intuitiva que remete a "algo a ser resolvido e que exige o pensar consciente do indivíduo para solucioná-lo" (DANTE, 2009, p. 11). O autor 
também inclui a ressalva de que algo que é um problema para uma pessoa, pode não ser para outra. Recorrendo à ilustração (figura 6), o autor explica que o pneu furado só seria um problema para o garoto se ele precisar consertá-lo, ou seja, se tiver necessidade de consertá-lo e não conhecer meios imediatos para fazer isso. Esse parece ser um importante complemento na definição de problema proposta anteriormente pelo autor, pois, a princípio, consertar o pneu da bicicleta exige que o personagem pense, de alguma maneira, mas isso não representa, necessariamente um problema, pois ele pode conhecer e dispor dos meios para o conserto imediato. Do contrário, se o personagem nunca teve o pneu da bicicleta furado e precisa consertá-lo, mas não sabe como, então ele tem um problema.

Outro indício de um movimento dos sentidos é a referência à composição "pensar consciente". É admissível que um sujeito esteja realizando alguma operação mecanicamente, de modo que não esteja o tempo todo consciente do que está fazendo. Isso não implica dizer que o sujeito está fazendo aquilo "sem pensar", apesar de as operações não estarem presentes na sua consciência. Tal compreensão, como vimos, vai ao encontro do que propõe Leontiev (1978), em relação à consciência. Logo, entendemos que os sentidos de Problema que o autor parece externar vão se aproximando mais de uma ideia segundo a qual o Problema tem o potencial de promover atribuição de sentidos e significados, no contexto em que compreendemos.

Importante destacar, também, que as referências do autor ao termo "formulação" aproximam-se da proposição presente na BNCC, já apresentada no subitem 1.2.3, em que o aluno é incentivado a desenvolver habilidades não apenas de resolução, mas também de formulação de Problemas, o que seria um indício de desenvolvimento da capacidade de expansão da compreensão acerca das condições particulares em que certo conceito matemático é aplicável. Em outras palavras, quando o aluno compreende um contexto de aplicação (resolver um Problema específico) ele também precisa ser capaz de expandir tal compreensão a outros contextos identificados por ele mesmo (formular Problemas), em um movimento de generalização. $O$ autor também passa a considerar diferentes aspetos da "formulação e resolução de problemas", mais uma vez, classificando os possíveis objetivos desse tipo de trabalho em sala de aula. Para ele 
(2009, p. 14 a 17), a formulação e resolução de Problemas em sala de aula pode ser compreendida

- Como meta, ou seja, resolver Problemas seria o propósito das práticas de ensino e o aluno aprenderia matemática para resolver Problemas;

- Como processo, ou seja, o processo como o aluno formula e resolve o Problema é mais importante do que a resposta em si;

- Como habilidade básica, numa compreensão próxima daquela que reconhecemos na BNCC, apresentada anteriormente, segundo a qual a habilidade de resolver Problemas deve ser desenvolvida como pressuposto básico para o exercício da cidadania;

- Como metodologia para o ensino da matemática, ou seja, em situações apresentadas pelo professor e que têm potencial para que o estudante vá aprendendo matemática à medida em que vai resolvendo os Problemas.

Entendemos serem estes, indícios de uma ampliação de sentidos a respeito de Problema que passam a englobar os problemas segundo seus usos em sala de aula e no processo pedagógico, superando a mera referência classificatória segundo técnicas de resolução a serem adotadas para as soluções que se espera.

Onuchic (2008), com o propósito de apresentar "uma história da resolução de problemas no Brasil e no mundo", parece colocar em evidência sentidos sobre Problemas em uma perspectiva que a autora chama de "pós-Pólya". Segundo essa autora, é nesse contexto "pós-Pólya" que os Problemas superam as heurísticas e a mera exigência ao pensar, genericamente, para comporem instrumentos metodológicos para o ensino de matemática. Em sua visão ainda, essa superação também remete à ideia de que, aos professores de matemática, bastaria serem "muito bons" em matemática, para que os alunos aprendessem. Considerando a locução "muito bom" como sinônima de conhecedor de vários aspectos de matemática avançada, tendemos a concordar com a professora Onuchic (2008), reconhecendo, como já apresentamos em nosso primeiro capítulo, sentidos que remetem à formação específica do professor de matemática em contraste a outros que compreendem ser suficiente a "adaptação" de bacharéis em matemática para o exercício da docência. 
Onuchic (2008) apresenta-se como coordenadora de um grupo de estudos e pesquisas sobre resolução de Problemas, junto à UNESP de Rio Claro, em São Paulo, em cujo âmbito ela propõe que os Problemas sejam centrais nas práticas pedagógicas ao subsidiem aspectos de uma metodologia que ela denomina "Ensino-AprendizagemAvaliação de matemática através da Resolução de Problemas". Em seus estudos, Onuchic (1999) delineia as pesquisas a respeito da resolução de Problemas segundo três vertentes: o ensino sobre a resolução de Problemas, o ensino para a resolução de Problemas e o ensino através da resolução de Problemas. No entender da autora, quando o professor assume o Problema como um objeto de aprendizagem, um conteúdo formal do currículo, ele tende a ensinar sobre a resolução de Problemas, apresentando definições, técnicas e aspectos históricos. Já os entendimentos da obra de Pólya conduziram a práticas que se situam, segundo a autora, no grupo do ensino para a resolução de Problemas, ou seja, o Problema assume o papel de incitar o aluno a usar aquilo que ele já aprendeu. Por fim, as práticas posteriores, dentre as quais a autora se reconhece, promovem o ensino através da resolução de Problemas, em que o papel do Problema passa a ser o de proporcionar a apropriação do conceito matemático em estudo, durante o processo de resolução, superando a mera apresentação de soluções para os Problemas.

Onuchic e Leal Júnior (2015) defendem que sua proposta metodológica se aproxima de uma perspectiva que denominam "sociointeracionista", remetendo às suas interpretações da obra de Vygotsky. Segundo esses autores "a Resolução de Problemas tem natureza sociointeracionista, já que o foco de sua atividade reside na base históricodialética [...] e não apenas interacionista e construtivista pela obra de Vygotsky, como muito se prega em trabalhos acadêmicos". Os autores não chegam a explicitar o que entendem por "natureza construtivista" na obra de Vygotsky, mas continuam sua apresentação em um sentido segundo o qual relacionam as ideias vygotskianas de zona de desenvolvimento real e zona de desenvolvimento imediata ao ato de imitar.

Certa ressalva precisa ser estabelecida, no entanto. Recorrendo ao segundo tomo de Obras Escogidas, de Vygotsky, Onuchic e Leal Júnior (2015) tratam da ideia de imitação como uma possibilidade de trabalho docente, trazendo a citação "[...] para se imitar é preciso ter alguma possibilidade de passar do que sei ao que não sei. [...] sendo 
a imitação a forma principal pela qual se leva a cabo a influência da instrução sobre o desenvolvimento" (VYGOTSKI, 1993, p. 241, apud ONUCHIC e LEAL JUNIOR, 2015, p. 959). A ideia de imitação que Vygotsky defende, todavia, precisa ser compreendida com cautela, sobretudo no contexto da resolução de Problemas. Não se trata da imitação para mera reprodução, como modelos prontos a serem seguidos ou como receituários determinísticos de procedimentos a serem seguidos. Ao contrário, trata-se de um aspecto do processo mediado em que um elemento medeia o desenvolvimento, para a zona de desenvolvimento imediato (ou proximal) ${ }^{16}$ a partir da zona de desenvolvimento real.

Em suas famosas experiências com chimpanzés, Köhler já esbarrou no seguinte problema: podem os animais imitar os atos intelectuais de outros animais? Será que as operações racionais dos macacos foram simplesmente assimiladas por imitação das soluções de problemas que em si mesmos são totalmente inacessíveis ao intelecto desses animais? As investigações mostraram que a imitação do animal está rigorosamente limitada as suas próprias possibilidades intelectuais. Noutros termos, o macaco (chimpanzé) pode, por imitação, fazer apenas aquilo que e capaz de fazer sozinho. A imitação não o faz avançar no campo das suas potencialidades intelectuais. É verdade que o macaco pode ser treinado para executar operações infinitamente mais complexas a que não chegaria por sua própria inteligência. Neste caso, porém, a operação seria executada simplesmente de forma automática e mecânica como habilidade sem sentido e não como solução racional e pensada. A psicologia animal estabeleceu vários sintomas, que permitem distinguir a imitação intelectual consciente da cópia automática (VYGOTSKY, 2001, p. 329-330).

Ou seja, a imitação, para Vygotsky, seria uma forma de promover uma aprendizagem que se adiante ao desenvolvimento, que o impulsione sem, no entanto, ser repetitiva ou modelar, mas mediadora. Dessa forma, o Problema não deveria meramente remeter a uma situação já estudada anteriormente, como um recurso de aplicação, mas sim a um conceito ainda não sabido a ser apropriado por meio de tal mediação, a partir do elemento mediador, que pode ser o professor, mas também o próprio Problema, o livro didático, etc.

Em suma, podemos verificar que, dentre algumas publicações e autores que têm

\footnotetext{
${ }^{16}$ O professor Paulo Bezerra, tradutor do Russo para o Português do livro "A construção do Pensamento e da Linguagem" (2001), pela editora Martins Fontes, no prólogo do tradutor, chama nossa atenção que esse conceito chegou ao Brasil traduzido como "zona de desenvolvimento proximal". Ele esclarece a opção pelo termo "imediato" ao invés de "proximal" pela interpretação de que, ainda que o termo utilizado por Vigotski, no original Russo, possa ser traduzido como "próximo", ele representa um superlativo, aproximando-se mais de algo como "proximíssimo", o que levou o tradutor a adotar o termo "imediato" e que optamos por manter no nosso texto.
} 
circulado no Brasil e que tratam de aspectos dos Problemas, o principal sentido parece remeter a aspectos relacionados à sua resolução, abrangendo técnicas de solução, como as heurísticas de Pólya, ou padronização de estruturas para constituição de um rol de Problemas de variados "tipos" que remetam às técnicas esperadas de solução. Também é possível inferir aspectos relacionados aos Problemas entendidos como meios para verificação da "adequada" aplicação de algoritmos, propriedades ou definições, como um fim em si mesmos, ou seja, tornando a matemática um elemento pragmático a ser aplicado para a solução de Problemas que remetem a situações do cotidiano. Mesmo nas publicações da professora Onuchic, que anunciam aspectos metodológicos para o trabalho com Problemas em sala de aula, verificamos apenas uma tendência classificatória ou descritiva do trabalho pedagógico pautado na resolução de Problemas. Onuchic e Andrade (2017, p. 439 a 441) chegam a apresentar um "roteiro de atividades destinado à orientação de professores para a condução de suas aulas" (ONUCHIC e ANDRADE, 2017, p. 439), indiciando sentidos sobre o papel do Problema na aprendizagem da organização do ensino que se aproximam daqueles propostos por Pólya para o trabalho voltado à aprendizagem da resolução de Problemas, ou seja, sendo descritivo e diretivo e deixando de considerar aspectos socioculturais do próprio professor, dos alunos, da escola e da cultura, de modo geral.

A ideia de "bom" Problema para as práticas relacionadas ao ensino de matemática passa pela constituição cultural e social dos objetivos da educação como um todo. As defesas de diferentes grupos a respeito de tais objetivos conduzem a uma percepção de quais Problemas seriam adequados para alcançá-los. Verifica-se, no entanto, que alguns significados produzidos no contexto de cada cultura "resistem" aos embates entre os diferentes grupos e à passagem do tempo, de modo a constituírem sentidos perceptíveis em práticas escolares atuais.

A formação de professores tem grande relevância na consolidação de um processo de significação que contribui para a constituição desses sentidos sobre o papel do Problema no ensino de matemática, já que, ao que parece, o silêncio a respeito de uma formação especificamente voltada à constituição de novos sentidos, teria como consequência a reprodução de modelos observados pelos professores durante suas experiências pregressas - reproduzindo, portanto, modelos de tempos passados. 
Segundo Virgens (2014), um significado sobre o papel do Problema nas práticas educacionais decorre dos métodos que enalteciam a imitação de modelos para reprodução. Um bom Problema a ser utilizado nas aulas de matemática, nessa concepção, seria qualquer questão que possibilitasse o exercício das lições (a experiência), até a pronta repetição sempre que situações parecidas se apresentassem nas mais diversas situações cotidianas, ou seja, até que as ideias envolvidas nas lições se consolidassem para a pronta aplicação quando fosse necessário.

Há, no entanto, significados sociais distintos sobre o papel do Problema nas práticas de ensino. Um desses significados decorre do movimento que tem como contexto os pressupostos da THC. Assim passamos, a seguir, a discutir os Problemas compreendidos como desencadeadores da atividade de ensino e, portanto, como elementos de destaque na aprendizagem de organização da atividade pedagógica.

\subsection{O Significado de Problema na perspectiva histórico-cultural}

Algumas pesquisas tratam da resolução de Problemas em um contexto de aplicabilidade de teorias de aprendizagem, como a Teoria das Aprendizagens Significativas (AUSUBEL, 1963) ou a Teoria das Situações Didáticas (BROUSSEAU, 2008) em que o Problema assume um papel de finalidade do processo educativo, com fim em si mesmo. Concordando com Moretti e Radford (2015), entendemos necessária a superação da perspectiva em que o Problema possui, por si só, a capacidade de fazer emergir um conceito matemático nele imbuído.

Por fim, focando a formação do educador matemático, compreendemos que não há uma formulação de problema matemático que, por ela mesma, faça emergir um determinado conceito ou conhecimento e, nesse sentido, o que apresentamos neste texto distingue-se da Teoria das Situações Didáticas (BROUSSEAU, 2008) segundo a qual para todo conceito matemático lhe corresponde uma situação, um problema matemático, que de certa forma vai forçar o aluno a utilizá-lo (o conceito). (MORETTI e RADFORD, 2015, p. 9).

Entendemos que, durante o processo de formação, o licenciando deve receber uma formação adequada para aprender a organizar o ensino, e para tanto os Problemas devem exercer protagonismo como desencadeador dos processos de ensino e de aprendizagem. 
Como temos indicado, nas salas de aula de matemática, o Problema, de maneira geral, admite uma composição lógico-formal do conceito, ou seja, parte do princípio de que os conceitos em estudo são objetos acabados e bem definidos existentes no exterior da escola (na ciência matemática) e assumem o papel de instrumentos de aplicação das definições e propriedades inerentes a tais conceitos, de maneira lógica e formal, como se tais definições e propriedades fossem "verdades absolutas", descobertas ou criadas por outras pessoas (geralmente, consideradas pessoas de "inteligência" muito acima da média), e que desde sempre tiveram as mesmas características que possuem hoje. Admitindo esse princípio, não é incomum perceber indícios de sentidos pessoais dos licenciandos que remetem ao esquema de organização das aulas que parte da apresentação da definição, pronta, passando às vezes pela apresentação de aspectos ilustrativos da História da Matemática envolvidos, em que personagens históricos são apresentados como pessoas com capacidades intelectuais destoantes dos demais, passam pelas propriedades e teoremas envolvidos - às vezes, demonstrando estes sob a alcunha da "trivialidade" ou, quando isso não é possível, argumentando que as demonstrações são "complexas demais" e não são relevantes para a aprendizagem (criando, assim, verdadeiros "dogmas" em que os alunos devem crer sem questionar) -, para só então serem apresentados Problemas, que sintetizariam tais definições e propriedades apresentadas previamente como "chave" de resolução para qualquer Problema relacionado àquele conceito em estudo.

Na perspectiva histórico-cultural, ao contrário, compreende-se que o sujeito se torna humano a partir da apropriação da produção cultural produzida pela humanidade, a partir de mediações que ocorrem em seu ambiente cultural, no contexto histórico, ou seja, o processo de humanização, ao mesmo tempo em que é social, é também marcado pela atividade do sujeito em sua interação com a cultura e os conhecimentos historicamente produzidos (MORETTI, 2014).

Um exemplo dessa perspectiva é a pesquisa de doutorado de Moretti (2007), intitulada "Professores de matemática em Atividade de Ensino: uma perspectiva históricocultural para a formação docente" (MORETTI, 2007). Naquela pesquisa o interesse principal remetia a como os professores envolvidos constituíam uma discussão sobre quais elementos poderiam contribuir para a aprendizagem dos alunos (MORETTI, 2007, 
p. 106). Um dos Problemas propostos abordava o conceito de função. Todavia, ao contrário das propostas tradicionais, não foi apresentado um Problema a ser resolvido a partir da definição lógico-formal do conceito ou de alguma propriedade específica decorrente de tal definição. O Problema foi apresentado a partir de um jogo.

Os professores jogaram os primeiros estágios e então pedimos a eles a previsão das condições de vitória para as próximas etapas do jogo. Para dar conta desse desafio, os professores viram-se diante da necessidade de representar o movimento de variação entre as grandezas envolvidas no problema (MORETTI, 2007, p. 106).

O jogo ${ }^{17}$ possuía potencial para suscitar a necessidade de os professores participantes do processo de formação continuada perceberem e controlarem as variações entre as grandezas envolvidas (número movimentos e discos), mas se for apenas apresentado aos participantes, ainda que seja resolvido adequadamente, não representa uma garantia de desenvolvimento do professor, nem uma reorganização de suas práticas. É por isso que Moretti (2007) adota aspectos metodológicos da Atividade Orientadora de Ensino (AOE), proposta por Moura (2002), entendida como aquela atividade que "se estrutura de modo a permitir que os sujeitos interajam, mediados por um conteúdo, negociando significados, com o objetivo de solucionar coletivamente uma situação-problema" (MOURA, 2001, p. 155 apud MORETTI, 2007, p. 96).

A autora entende que

Assim como a atividade humana responde a uma necessidade, seja ela material ou ideal, a atividade orientadora de ensino responde à necessidade do professor de organizar o ensino de modo a favorecer a aprendizagem de seus alunos sobre um conteúdo construído historicamente (MORETTI, 2007, p. 96).

Em conclusão à sua pesquisa, Moretti (2007) entende que os processos de formação do professor, segundo a perspectiva histórico-cultural, constituem-se como um movimento que o coloca em atividade de estudo da organização do ensino, tanto quanto do estudo dos próprios conceitos matemáticos envolvidos, o que pressupõe mudanças de motivos em razão da busca por respostas adequadas às necessidades que originam o

17 O jogo adotado era A Torre de Hanói (ou Torre de Lucas). Para mais, ver Moretti (2007), disponível em: <http://www.teses.usp.br/teses/disponiveis/48/48134/tde-05102007-153534/pt-br.php>. 
movimento. Assim, retomando a indicação leontieviana de que os motivos são dialeticamente relacionados aos sentidos, entendemos que ao entrar em atividade de estudo da organização do ensino, os sentidos pessoais dos licenciandos se movimentam de modo que "nesse percurso, o novo fazer do professor [se constitua], de forma mediada, na práxis pedagógica, entendida como unidade dialética entre a atividade prática e atividade teórica dos professores" (MORETTI, 2007 p. 187).

Podemos concluir, então, que o significado de Problema, no movimento de significação que admite os pressupostos da Teoria Histórico-cultural, não poderia limitarse à "criação" de uma ponte entre o "sabido" (definição) e o "não-sabido" (resposta das questões propostas), ignorando a cultura e a história de cada indivíduo e dos conceitos em estudo no processo de produção do conhecimento pela humanidade. Isso significaria mera adaptação do indivíduo às condições do meio que se apresentam à testagem de seus conhecimentos. Um Problema, na perspectiva histórico-cultural, deve ser aquele capaz de colocar o aluno diante da necessidade de apropriar-se do conceito em estudo, que foi historicamente produzido pela humanidade.

$\mathrm{Na}$ escola, se os Problemas presentes nos recursos didáticos dos quais o professor lança mão para a organização do ensino não servirem ao propósito de suscitar a necessidade que levou a humanidade à construção do conceito (e, geralmente, não servem, pois são meros recursos de aplicação), o professor precisará, então, elaborar os próprios Problemas ou adaptar situações que contenham tais Problemas. Não podemos, coerentemente com os pressupostos que já elencamos, esperar que a capacidade de elaborar Problemas impregnados das necessidades histórico-culturais dos conceitos a serem ensinados seja desenvolvida ao acaso. Por isso essa capacidade de elaboração ou adaptação dos Problemas precisa ser parte do processo formativo.

Tal processo formativo, por sua vez e coerentemente, deve ser intencionalmente organizado segundo uma estrutura própria da atividade. A História da matemática - HM, nesse contexto, desempenha um papel protagonista na elaboração do que temos denominado como Problemas Desencadeadores de Aprendizagem - PDA, já que compreendemos que o papel do Problema no ensino de matemática seja o de reproduzir a necessidade que, historicamente, levou a humanidade à construção do conceito. 
Para se apropriar dos objetos ou dos fenômenos que são o produto do desenvolvimento histórico, é necessário desenvolver em relação a eles uma atividade que se reproduza, pela sua forma, os traços essenciais da atividade encarnada, acumulada no objeto (LEONTIEV, 1978, p. 268).

Com isso, contudo, não esperamos que o professor, necessariamente, reproduza a história da matemática em sua sala de aula. Mas que reconheça o conceito que deseja ensinar como fruto de um processo histórico e não como "algo pronto", como se sempre tivesse existido da forma como conhecemos hoje. Não se espera que, por exemplo, ao tratar da noção de número, o professor leve, necessariamente, as crianças a contar pedrinhas ou riscar ossos, de acordo com o que apresentam diversos autores sobre a origem dos números na História da Matemática. Mas que, no processo de estudo dessa história, na organização da atividade orientadora de ensino, o professor reconheça a relação um-a-um estabelecida entre o objeto a ser contado e o risco no osso ou a pedrinha selecionada, a necessidade do controle de quantidades, a importância do zero e do valor posicional e os sistemas de agrupamentos como nexos conceituais essenciais para a apropriação do conceito de número. Assim, o professor poderá apresentar situações que reproduzam a correspondência um-a-um, o controle quantidades, a importância do zero, do valor posicional e dos agrupamentos, e, no contexto dessas situações, propor Problemas que possam desencadear a aprendizagem do conceito de número. Essas situações que contextualizam o Problema são as Situações Desencadeadoras de Aprendizagem - SDA, e trataremos mais detidamente delas mais adiante, nesse mesmo capítulo.

Entendemos que o papel da História da Matemática na formação inicial de professores de matemática deva superar a mera contação de histórias. De acordo com Radford (2011, p. 73), embora se possa estimular a motivação de alguns alunos por meio da HM abordada segundo a perspectiva da contação, seu uso nesse contexto, se mantém superficial. Mais do que, simplesmente, apresentar uma história factual aos licenciandos, para que estes possam, posteriormente, reproduzir a contação dessas histórias a seus alunos, é fundamental para a formação do professor que ensinará matemática a apropriação do que nós denominamos, a partir desta pesquisa, como História da Matemática Conceitual. 
A História da Matemática Conceitual remete aos estudos históricos que visam superar a caracterização cronológica, geográfica e espacial presente nos livros de $\mathrm{HM} \mathrm{e}$ a forma como, geralmente, é apresentada nos cursos de formação de professores, passando a compreendê-la como fonte reveladora da essência dos conceitos matemáticos a serem ensinados, dos nexos conceituais e dos problemas humanos que suscitaram as necessidades envolvidas no processo de significação dos conceitos. A partir dessa compreensão de uma História da Matemática Conceitual poderíamos inferir as necessidades humanas que se verificam na gênese do conceito e dão início a um movimento histórico-lógico de produção humana. Desse modo seria subsidiada a elaboração ou a adaptação de Problemas para que assumissem o papel de desencadeadores de aprendizagem. Em outras palavras, os estudos voltados a uma História da Matemática Conceitual podem ser destacados no contexto da aprendizagem da organização do ensino, pois são destes estudos que emergem as necessidades que permitem a elaboração e proposição de bons Problemas que potencializam 0 desencadeamento da aprendizagem.

Quando estudamos a história da produção do conhecimento, percebemos que os conhecimentos são produzidos na relação dos homens entre si e destes com a natureza, como um meio de potencializar as ações humanas de intervenção, modificação e controle dos fenômenos circundantes. Nesse processo, os conceitos criados se objetivam como instrumentos simbólicos, ou seja, neles está fixado o processo de trabalho humano (MOURA, SFORNI e ARAÚJO, 2011, p. 41).

A História da Matemática nos cursos de licenciatura, no entanto, é concebida no contexto da "contação de histórias", em que se priorizam nomes, datas, períodos, civilizações, "curiosidades" e até mitos e lendas, em detrimento da compreensão do desenvolvimento histórico dos conceitos. A própria organização dos livros de História da matemática, tradicionalmente incluídos nos referenciais das disciplinas de HM dos cursos de licenciatura, prioriza uma organização de cunho essencialmente cronológico geral, na qual cada conceito aparece disperso num emaranhado de informações sobre pessoas e fatos diversos. O estudo da HM, no contexto da formação voltada à elaboração de PDA, em perspectiva histórico-cultural, pressupõe, portanto, a superação dessa característica em favor de um processo que busque compreender a essência de cada conceito desenvolvido historicamente. 
$\mathrm{Na}$ atividade orientadora de ensino o professor desenvolve diversas ações, que são aquelas necessárias para que se alcance seu objetivo. Por exemplo, uma possível ação da atividade orientadora de ensino, se dá quando o professor realiza um estudo da HM para compreender a essência do conceito que se quer ensinar. Nesse caso, seu objetivo não é o conhecimento histórico em si, ou seja, seu motivo (estudar a história do conceito) não coincide exatamente com seu objeto (o ensino do próprio conceito). No entanto, a compreensão de como as necessidades que culminaram no desenvolvimento do referido conceito podem colocar os alunos em um movimento que leve à aprendizagem, se constitui como uma ação necessária à atividade.

Durante a aula o professor está em atividade de ensino porque suas ações são motivadas pela necessidade de ensinar. Assim, por exemplo, ao pedir que os alunos sentem-se em grupos, seu motivo não é a constituição do grupo em si, mas sim a relação que o professor acredita existir entre o trabalho em grupos e o quanto isso pode favorecer a aprendizagem de seus alunos. Ou seja, essa ação do professor responde à necessidade de sua atividade principal - ensinar - ao mesmo tempo em que responde à necessidade de organizar o ensino de modo a favorecer a aprendizagem de seus alunos (MORETTI, 2007, p. 100).

No entanto, nem sempre será necessário que o professor busque um livro ou um curso específico sobre HM, por exemplo, para a compreensão da essência histórica do conceito. Muitas vezes, diversas ações em uma atividade caracterizam o que Leontiev (1978, p. 74) denomina operações. As operações não se confundem com a própria ação, porquanto, são os modos pelos quais se alcança o objetivo da ação. É possível, de acordo com Leontiev (1978) que a mesma operação seja empregada em diferentes ações, ou mesmo que uma ação demande distintas operações. No entanto, o surgimento de operações conscientes sempre decorre de ações. No nosso exemplo, ao se compreender historicamente o conceito que objetivará na sua atividade de ensino, ou seja, ao concretizar sua ação, o professor pode, em razão de outra ação, como a elaboração do PDA, adotar aquela "compreensão da essência do conceito" como uma operação.

Entendemos que a aprendizagem decorrente desse processo se identifica com o que Vygotsky (2001) chamou de processo de internalização. A internalização, nesse contexto vygotskiano, pressupõe que as relações intrapsíquicas - individuais do sujeito constituem-se nas relações interpsíquicas - coletivas. E, considerando a internalização dos conceitos, o estudante pode produzir um sentido convergente para os significados 
impregnados nas definições e propriedades inerentes a esses conceitos e, então, poder "acessar" esse conhecimento para a resolução de qualquer situação, inclusive aquelas de mera aplicação da definição ou das propriedades. Ou seja, a organização do ensino segundo o que se propõe na atividade orientadora de ensino, não nega a importância da aplicabilidade conceitual no cotidiano, mas a incorpora, já que as situações desencadeadoras de aprendizagem e os PDA suscitam as necessidades de apropriação dos conceitos que, uma vez apropriados, permitem essa aplicabilidade.

Quando a prática docente é pautada na apresentação do conceito "pronto" (dissociado de seus aspectos histórico-culturais) os processos de aprendizagem e de ensino, inevitavelmente, tornam-se técnicos e reprodutivos, potencializando a alienação. Duarte (2004, p. 59), tratando da ideia de alienação nos trabalhos de Leontiev, indica que a alienação se dá com "a da criação de obstáculos, por parte da sociedade capitalista, à apropriação da cultura humana pelos indivíduos", situação potencializada, sem dúvida, pela dissociação entre o Problema e a produção humana impregnada no conceito. Assim, nesse processo, as ações desenvolvidas com o objetivo de resolver o Problema, motivadas pela necessidade de apropriação dos conceitos nele impregnados podem, no contexto de um processo intencional e mediado, colocar o sujeito em atividade, possibilitando com isso, de acordo com a teoria defendida por Leontiev, o processo de apropriação histórico-cultural do conceito e o desenvolvimento psíquico, permitindo a "reprodução" interior da produção humana "exterior".

É preciso salientar também uma necessária distinção entre os diversos possíveis usos para o termo "apropriação". Alguns textos dão ao termo uma conotação, pejorativa, de transmissão de saberes, como se o professor fosse o detentor do conhecimento e o aluno se apropriasse desse conhecimento, de forma passiva, enquanto absorve o que 0 professor transmite. Não obstantes a certas práticas que, de fato, dão causa a essa conotação do termo, em nossa análise, por apropriação deve-se entender, como já explicitado, o movimento em que o sujeito, em busca de satisfazer suas necessidades, reconhece a produção cultural da humanidade como sua e, com isso, constitui novos sentidos pessoais ao modificar os motivos que o colocam em atividade. Não é absolutamente uma ação passiva e não pressupõe uma "propriedade" do conhecimento. 
Pelo contrário, entende o professor como um sujeito mais experiente na atividade e que potencializa a mediação entre aspectos singulares e universais da significação social.

Como a experiência social está acumulada nos objetos e fenômenos culturais e esta não é 'dada imediatamente ao indivíduo', sua apropriação torna imprescindível a presença de outro mais experiente que, de maneira formal ou informal, transmite às novas gerações o conhecimento já acumulado. Como o conhecimento produzido na contemporaneidade é muito maior do que a experiência particular de cada sujeito pode alcançar informalmente, a apropriação dos produtos culturais no atual contexto implica necessariamente a transmissão intencional da experiência social por meio das instituições educativas (MOURA, SFORNI e ARAÚJO, 2011, p. 44).

E aqui, verificamos a necessidade de delimitar o que entendemos por mediação. Mediação, como entendemos nesta pesquisa, é um conceito originado nos estudos de Vygotsky, entendido como "processo de intervenção de um elemento intermediário numa relação; a relação deixa, então, de ser direta e passa a ser mediada por esse elemento" (OLIVEIRA, 1993, p. 26).

Entendemos, a partir da interpretação de Vygotsky (2001), que o processo de aprendizagem pressupõe um momento em que o sujeito resolve problemas com auxílio de outro elemento - por exemplo, o professor - até o momento em que passa a resolver problemas sozinho. Esses momentos são, respectivamente, a zona de desenvolvimento imediato e a zona de desenvolvimento real. Quando avaliamos o nível de "maturação", de desenvolvimento, de um sujeito por meio, exclusivamente, de testes de aplicação, estamos avaliando apenas os problemas que ele pode resolver sozinho, ou seja, a zona de desenvolvimento real. Mas Vygotsky chama a atenção para a necessidade de avaliar também aquilo que está em desenvolvimento.

Como um jardineiro que, para definir o estado de todo o jardim, não pode resolver avalia-lo apenas pelas macieiras que já amadureceram e deram frutos, mas deve considerar também as árvores em maturação, o psicólogo que avalia o estado do desenvolvimento também deve levar em conta não só as funções já maduras, mas aquelas em maturação, não só o nível atual, mas também a zona de desenvolvimento imediato (VYGOTSKY, 2001, p. 327).

O processo de avaliação do nível de desenvolvimento real pressupõe uma apropriação que já se processou e consolidou, de modo que o sujeito é capaz de realizar autonomamente as tarefas a ele apresentadas que têm relação com tal conhecimento. 


\begin{abstract}
Suponhamos que nós definimos a idade mental de duas crianças que verificamos ser equivalente a oito anos. Se não nos detemos neste ponto, mas tentamos esclarecer como ambas as crianças resolvem testes destinados a crianças das idades seguintes - que elas não estão em condição de resolver sozinhas - e se as ajudamos com demonstrações, perguntas sugestivas, início de solução, etc., verificamos que uma das crianças pode, com ajuda, em cooperação e por sugestão, resolver problemas elaborados para uma criança de doze anos, ao passo que a outra não consegue ir além da solução de problemas para crianças de nove anos. Essa discrepância entre a idade mental real ou nível de desenvolvimento atual, que é definida com o auxílio dos problemas resolvidos com autonomia, e o nível que ela atinge ao resolver problemas sem autonomia, em colaboração com outra pessoa, determina a zona de desenvolvimento imediato da criança. Em nosso exemplo, esta zona é de quatro anos para a primeira criança e de um para a segunda. Podemos afirmar que o nível de desenvolvimento mental das duas crianças é o mesmo e que o estado do seu desenvolvimento coincide? Nossa pesquisa mostra que, na escola, entre essas crianças haverá muito mais diferenças, condicionadas pela discrepância entre as suas zonas de desenvolvimento imediato, que semelhança gerada pelo mesmo nível do seu desenvolvimento atual (VYGOTSKY, 2001, p. 327).
\end{abstract}

O elemento "intermediário" que se apresenta na relação entre o sujeito - que está aprendendo - e o objeto - que deve ser aprendido - é o que compõe a mediação. Não raras vezes, o professor e o mediador se confundem, mas a mediação é realizada na intervenção que se apresenta diante da incapacidade de resolver situações autonomamente. Assim, o mediador pode ser qualquer elemento externo que interfira na relação direta entre sujeito e objeto. Quando, por exemplo, para resolver um exercício de matemática que não consegue realizar sozinho, o aluno recorre a um livro de onde ele abstrai "demonstrações, perguntas sugestivas, início de solução", etc., o elemento mediador foi esse livro.

Sendo ensinar a necessidade do professor e aprender a do aluno, a unidade verificada entre a atividade do aluno e a do professor constitui a Atividade Orientadora de Ensino - AOE (MOURA, 1996; 2002), que é composta "por conteúdos, objetivos e métodos dimensionados pelas interações histórico-culturais dos três elementos fundamentais do ensino: o objeto do conhecimento, o professor e o estudante" (MOURA, SFORNI e ARAÚJO, 2011, p. 40). É no contexto da AOE que podemos compreender as, já anunciadas, Situações Desencadeadoras de Aprendizagem - SDA (MOURA, 1996) que objetivam ensinar matemática, gerando um motivo compreensível, como definimos no subitem 2.1.1, que coloca o aluno em movimento.

As SDA consideram "a história do conceito, o lúdico, a interação, a ação do professor, a avaliação e a atividade orientadora de ensino" (MOURA, 1996, p. 11) na busca 
por possibilitar aos estudantes, a partir dos esforços para a solução coletiva de Problemas (MOURA, SFORNI e ARAÚJO, 2011, p. 40), a se apropriarem do conhecimento durante o "ato de produzir os significados desse conhecimento no compartilhamento com os outros" (MOURA, 1996, p. 12).

Dessa forma, os Problemas envolvidos nas SDA, não são Problemas "quaisquer", que promoveriam a aplicação direta de definições conhecidas. São Problemas Desencadeadores de Aprendizagem - PDA. Seu caráter desencadeador pressupõe Problemas que possuam impregnados em si as necessidades que, historicamente, culminaram nos significados sociais dos conceitos.

[O] problema desencadeia uma busca de solução, permite um avanço do conhecimento desse sujeito por meio do processo de análise e síntese e the permite desenvolver a capacidade de lidar com outros conhecimentos a partir dos conhecimentos que vai adquirindo à medida que desenvolve a sua capacidade de resolver problemas (MOURA, 2000, p. 35)

Entendemos, então, que os PDA são o fio condutor, a essência, a provocação que, no contexto da Situação Desencadeadora de Aprendizagem, colocam o sujeito em movimento. De acordo com Moura e Lanner Moura (1998) as SDA podem se materializar em uma história virtual, assim compreendida a situação fictícia que se propõe a simular o movimento histórico factual, em um jogo ou em Problemas que emergem de situações cotidianas.

[...] o jogo com propósito pedagógico pode ser um importante aliado no ensino, já que preserva o caráter de problema. [...] O que devemos considerar é a possibilidade do jogo colocar a criança diante de uma situação-problema semelhante à vivenciada pelo homem ao lidar com conceitos matemáticos. [...] A problematização de situações emergentes do cotidiano possibilita à prática educativa oportunidade de colocar a criança diante da necessidade de vivenciar solução de problemas significativos para ela. [...] a história virtual do conceito coloca a criança diante de uma situação problema semelhante àquela vivida pelo o homem (no sentido genérico) (MOURA e LANNER DE MOURA, 1998, p. 12-14, destaques nossos).

Verificamos que nas formas de materialização das SDA, propostas pelos autores, o Problema constitui-se como essência do desencadeamento da aprendizagem. Dessa forma, entendemos que o Problema Desencadeador de Aprendizagem se constitui como a essência da SDA. O PDA não é sinônimo da SDA nem, tão pouco, se confunde com ela, mas é seu elemento essencial. 
Em resumo, o PDA é o elemento, essencial, que suscitará na SDA a necessidade que desencadeará o movimento de ensino - por parte do professor - e de aprendizagem - por parte do aluno - que possibilitarão que ambos (professor e aluno) entrem em atividade. Sendo esse elemento essencial, o PDA pode aparecer no contexto do jogo, nas situações emergentes do cotidiano ou nas histórias virtuais, mas será sempre a "provocação" que, no contexto da organização consciente da atividade, subsidiará a constituição da SDA que envolve, como vemos nas palavras de Moura $(2000$, p. 35) "a busca de [uma] solução, [que] permite um avanço do conhecimento desse sujeito por meio do processo de análise e síntese e the permite desenvolver a capacidade de lidar com outros conhecimentos". A SDA deve, portanto, potencializar um "algo mais" no processo de aprendizagem, para além da solução em si e não apenas uma reconstituição dos passos já dados, já que, de acordo com Vygotsky (2001), o bom ensino é aquele que precede o desenvolvimento. Dessa forma, Problema presente na SDA precisa possuir, como essência, "a necessidade que levou a humanidade à construção do conceito" (MORETTI e MOURA, 2011, p. 442), para que, na busca pela solução, no contexto da $\mathrm{AOE}$, o aluno possa alcançar esse "algo mais" caracterizado pelo desenvolvimento da capacidade de lidar com outros conhecimentos.

Podemos verificar, neste capítulo, um movimento de significação que vem possibilitando a conformação de sentidos e significados diversos sobre qual o papel do Problema nas aulas de matemática. Buscamos dar mais um passo em direção a aspectos relacionados à aprendizagem da docência, compreendida como organização, execução e avaliação consciente da atividade pedagógica, tendo como unidade de análise o Problema na perspectiva histórico-cultural que, como já afirmamos, estamos denominando como Problema Desencadeador de Aprendizagem - PDA. Entendemos o significado de PDA como fruto de um processo de significação decorrente de práticas formativas de professores em uma perspectiva histórico-cultural, em que os sujeitos em formação vão aprendendo a ser professores no contexto da atividade, portanto em movimentos intencionalmente organizados e nos quais os sentidos pessoais sobre 0 papel do Problema em sua práxis podem se movimentar e convergir para um significado de Problema entendido como desencadeador de aprendizagem. Para tanto, lançamos 
mão de aspectos metodológicos coerentes com tal opção teórica e nos deteremos a apresentar tais considerações metodológicas no capítulo seguinte. 


\section{CAPÍTULO 3}

\section{ASPECTOS METODOLÓGICOS DA PESQUISA}




\section{ASPECTOS METODOLÓGICOS DA PESQUISA}

Até recentemente, a maior dificuldade no campo do estudo dos conceitos foi a ausência de uma metodologia experimental elaborada que permitisse penetrar fundo no processo de formação dos conceitos e estudar a sua natureza psicológica.

Lev Semionovich Vygotsky ${ }^{18}$

Ao admitir o aspecto histórico-cultural do processo de humanização do homem torna-se implícita nossa opção metodológica pelo materialismo histórico-dialético, em uma perspectiva marxista. Dessa forma, como vimos no subcapítulo 2.1, podemos observar o movimento de formação que nos interessa a partir de uma concepção histórica e tecer sobre tal movimento uma análise crítica em busca da compreensão do fenômeno. É a crítica que nos permite o reconhecimento das contradições inerentes aos objetos e ao próprio movimento e, portanto, a constituição de superações e sínteses.

Quando podemos acompanhar aspectos do processo de formação dos licenciandos, que possibilitam destacar sentidos sobre o papel dos Problemas nas aulas de matemática, podemos apresentar uma explicação do fenômeno, e não apenas uma descrição do mesmo, podendo, assim, desnaturalizar situações para superar o problema do "comportamento fossilizado", conforme indica Vygotsky, como vimos. Considerando a metodologia materialista dialética, organizamos um experimento formativo, como fonte de produção e coleta de dados. Apresentamos a seguir aspectos desse experimento.

\subsection{O experimento formativo}

Um experimento formativo, de acordo com Cedro (2008, p.105), "é um método de investigação psicológico que permite estudar a essência das relações internas entre os diferentes procedimentos do ensino e o correspondente caráter de desenvolvimento psíquico do indivíduo".

Assim como Vygotsky, entendemos que o experimento genético formativo é uma forma de investigação que permite analisar e compreender a gênese e o desenvolvimento dos aspectos conscientes da relação dos seres humanos com o mundo (CEDRO e MOURA, 2016). Essa é a fundamentação basilar que origina o que compreendemos como experimento formativo. Ao propormos um experimento, intencionalmente

\footnotetext{
${ }^{18}$ VYGOTSKY, L.S. A construção do pensamento e da linguagem. São Paulo, SP: Martins Fontes, 2001.
} 
organizado, que possibilita investigar a gênese e o desenvolvimento dos aspectos da aprendizagem da docência, estamos propondo um experimento formativo. De acordo com Cedro (2008)

\begin{abstract}
Em linhas gerais, podemos caracterizar o experimento formativo da seguinte maneira: pelo caráter qualitativo dos dados coletados; pela orientação para os processos descobertos pelos indivíduos ao se apropriarem dos conhecimentos inerentes à formação do professor; pela participação ativa do pesquisador na aprendizagem dos indivíduos; pela constante interação entre as observações coletadas e o planejamento futuro das ações; pela natureza longitudinal do trabalho desenvolvido (CEDRO, 2008, p. 106).
\end{abstract}

Particularmente, o experimento formativo que realizamos no contexto do curso de formação inicial de professores de matemática, teve como perspectiva acompanhar longitudinalmente o movimento dos sentidos pessoais dos licenciandos sobre o papel dos Problemas na organização do ensino. Isso porque, de acordo com Leontiev (1978, p. 97), como vimos, "para encontrar o sentido pessoal devemos descobrir o motivo que the corresponde", o que implica que o movimento dos sentidos sobre o papel do Problema implicaria possíveis alterações de motivos, passando de compreensíveis para eficazes, e coincidindo com os objetos, caracterizando a atividade.

O experimento formativo que realizamos, conforme a indicação de Cedro (2008), pode ser caracterizado pelo aspecto qualitativo dos dados coletados, uma vez que analisamos um fenômeno em movimento, relacionado à aprendizagem da organização do ensino, de modo que os dados analisados superam a mera análise quantitativa e, também, não se limita à descrição do fenômeno. Nesse contexto as ações que realizamos foram orientadas para os processos descobertos pelos sujeitos ao se apropriarem dos conhecimentos inerentes à formação do professor, relacionados ao papel do Problema na organização do ensino e no processo de aprendizagem.

Outro aspecto que caracteriza o experimento formativo, de acordo com Cedro (2008), e que pôde ser destacado no movimento que acompanhamos foi a participação ativa do pesquisador na aprendizagem dos sujeitos, ou seja, a intencionalidade e arcabouço teórico que adotamos para a organização e execução do experimento evidenciou a unidade entre nossos objetivos de ensino e os de aprendizagem dos licenciandos. As intervenções que realizamos também foram motivadas pelas relações que 
observamos entre aquilo que foi realizado e o planejamento das ações posteriores, como indicaremos mais adiante, neste mesmo capítulo.

O movimento realizado, como já indicamos, constitui-se como um experimento formativo, em concordância com Cedro (2008), não apenas pelo caráter qualitativo dos dados coletados, mas também pela orientação conferida aos processos descobertos pelos licenciandos enquanto se apropriavam dos conhecimentos inerentes à formação do professor, especialmente a organização da $\mathrm{AOE}$, e pela participação ativa do pesquisador na qualidade de professor para a constante inter-relação entre as observações coletadas e o planejamento futuro das ações, além da natureza longitudinal do trabalho, desenvolvido ao longo de dezenove encontros presenciais.

O planejamento do que pretendíamos ser o experimento previa, inicialmente, o acompanhamento de um movimento formativo, durante o primeiro semestre de 2017, em que os licenciandos estudariam aspectos gerais sobre o papel dos Problemas nas práticas docentes e no qual esperava-se que os mesmos elaborassem, voluntariamente, seus próprios Problemas que deveriam ser utilizados em suas regências de estágio. Entendemos, no entanto, que esse movimento inicial não pôde ser caracterizado como parte do experimento formativo, como indicaremos no próximo subitem.

Essa etapa anterior ao próprio experimento, no entanto, subsidiou a escolha dos sujeitos que participaram do experimento formativo, bem como suscitou os indícios de sentidos pessoais iniciais dos licenciandos, que apresentaremos no capítulo 4.

\subsubsection{Etapa exploratória pré-experimento formativo}

A proposta inicial foi realizada ao longo do primeiro semestre letivo do ano de 2017. Naquele momento propusemos uma organização que apresentasse aos licenciandos aspectos relacionados aos diversos possíveis papeis do Problemas nas aulas de matemática, entre estes, com ênfase, o desencadeamento da aprendizagem. A forma como organizamos os encontros, no entanto, remeteu mais à formação dos aspectos relacionados à disciplina do curso do que a um movimento formativo que permitisse analisar o movimento dos sentidos dos licenciandos. Isso ocorreu porque a proposta consistia em apresentar situações desencadeadoras de aprendizagem da matemática, como modelos, para que os licenciandos elaborassem, eles próprios, Problemas que pudessem ser considerados como desencadeadores de aprendizagem. Posteriormente, 
no entanto, reconhecemos esse movimento como contraditório, pois, se entendíamos que o Problema não deveria ser mero instrumento de reprodução de modelos matemáticos apresentados previamente, a elaboração de Problemas a partir de modelos de SDA prontas não teria o potencial de suscitar a necessidade de elaborar o PDA e se configuraria como mera reprodução de situações semelhantes àquelas que havíamos proposto.

Um exemplo das razões que nos permitiram concluir que aquele primeiro momento não poderia ser caracterizado como um experimento formativo, ocorreu quando propusemos a apresentação de algumas situações desencadeadoras de aprendizagem de alguns conceitos matemáticos. A primeira SDA que propusemos aos alunos foi a "Carta Caitité"19.

A proposta foi apresentada para ser resolvida em grupos, com até 4 alunos. Os licenciandos levaram cerca de uma aula (45 minutos) para solucionar o Problema proposto na situação, sem haver intervenção do professor para encontrar as soluções. No entanto, como pesquisador, verificamos que durante a discussão sobre as respostas apresentadas pelos estudantes, explicitamos aspectos histórico-lógicos envolvidos na SDA. A discussão foi realizada, a partir daí, pela abordagem de aspectos comparativos entre práticas de ensino "tradicionais" para o ensino dos sistemas de numeração e aquela que poderia ser desenvolvida a partir da Carta Caitité.

Indicamos que, enquanto a Carta Caitité suscita uma necessidade relacionada à lógica de organização do sistema numérico que poderia ser desencadeadora da aprendizagem do nosso próprio sistema de numeração, as abordagens, ditas "tradicionais", apresentavam alguns sistemas de numeração da antiguidade, bem como suas regras de composição e tratando da identificação de números escritos nesses sistemas, da "conversão" de números do "nosso" sistema para esses outros, ou viceversa, ou da utilização desses números de outros sistemas em contextos atuais, como no caso do sistema romano de numeração.

Aquela nossa opção, como professor naquele momento, no entanto, alinhava-se à nossa própria crítica, na pesquisa, ou seja, ao mesmo tempo em que reconhecíamos que as práticas "tradicionais" enfatizavam a constituição lógico-formal do conceito

\footnotetext{
${ }^{19}$ A SDA foi criada pelo professor Manoel Oriosvaldo de Moura e está apresentada nos Anexos.
} 
matemático em estudo (sistemas de numeração), por apresentar aspectos conceituais como se sempre tivessem existido da forma como conhecemos hoje, estávamos também, no contexto da formação de professores, apresentando a SDA segundo uma compreensão lógico-formal, já que apresentávamos, como "prontos", aspectos da composição da própria SDA que deveriam fazer parte da atividade de aprendizagem dos licenciandos sobre ela, e não serem objeto de apresentação lógico-formal na expectativa de que os alunos "acreditassem" que seria um bom instrumento de organização do ensino.

Esse primeiro momento, no entanto, nos permitiu sondar sentidos pessoais iniciais dos licenciandos sobre a papel dos Problemas para a prática do professor de matemática e para a constituição de um modo de organização do ensino. Também nos permitiu estabelecer critérios para uma necessária redução no número de participantes do experimento formativo, em relação ao número de participantes da etapa inicial. Naquele primeiro momento participaram das ações todos os vinte e nove licenciandos que se matricularam nas disciplinas Prática de Ensino 3 e Prática de Ensino 4, que davam contexto à nossa proposta conforme indicamos no subitem 1.2.4.

Considerando que nosso objetivo de pesquisa remete a acompanhar o movimento dos sentidos no contexto do experimento formativo e que nosso referencial teórico evidencia o caráter de pessoalidade dos sentidos, concluímos que não seria adequada, para esta pesquisa, uma análise que remetesse ao movimento dos sentidos pessoais de vinte e nove sujeitos. Assim, a partir da realização desse primeiro movimento, pudemos reduzir esse número para sete licenciandos, selecionados dentre os vinte e nove, por terem manifestado indícios de sentidos pessoais iniciais sobre o papel do Problema nas aulas de matemática, reconhecidos a partir das regências de estágio realizadas naquele primeiro semestre, bem como das gravações de áudio das aulas das disciplinas, dos registros de pesquisa, das fichas de registro das soluções propostas pelos alunos para as tarefas.

Naquele movimento que realizamos inicialmente foram propostas algumas situações desencadeadoras de aprendizagem de conceitos matemáticos específicos. Ainda que, como já indicamos, os licenciandos não tenham, a nosso juízo, entrado em atividade e que não tenhamos podido identificar um movimento de seus sentidos sobre o conceito de Problema, entendemos ser importante apresentar, ainda que resumidamente, 
momentos daquela etapa para que seja possível perceber também os indícios a partir dos quais emergiram nossas compreensões sobre os sentidos iniciais dos licenciandos. É com esse propósito que apresentamos o quadro 3 resume a proposta desenvolvida naquele momento. 
Quadro 3: Resumo encontros das disciplinas de Prática de Ensino ( $1^{\circ}$ semestre de 2017 - Etapa exploratória pré-experimento formativo)

\begin{tabular}{|c|c|c|c|}
\hline Encontro & Objetivos iniciais & $\begin{array}{l}\text { Instrumentos } \\
\text { de coleta de } \\
\text { dados }\end{array}$ & Resumo do desenvolvimento \\
\hline 1 & $\begin{array}{l}\text { Apresentar objetivos da pesquisa, o professor e conhecer } \\
\text { os licenciandos. } \\
\text { Levantamento de concepções pessoais acerca do que } \\
\text { seria, para eles, um bom Problema de matemática; o que } \\
\text { significaria, para eles, utilizar Problemas nas aulas. }\end{array}$ & $\begin{array}{l}\text { Gravador; } \\
\text { Anotações do } \\
\text { professor. }\end{array}$ & $\begin{array}{l}\text { Foram apresentados os objetivos e aspectos gerais da } \\
\text { pesquisa e o modo como a mesma se articulava com a } \\
\text { disciplina do curso; Foram discutidos aspectos } \\
\text { relacionados ao papel dos Problemas na formação dos } \\
\text { licenciandos e sobre a percepção deles sobre esse papel } \\
\text { em suas próprias práticas pedagógicas. }\end{array}$ \\
\hline 2 & $\begin{array}{l}\text { Reconhecer aspectos relacionados ao ensino para a e pela } \\
\text { resolução de Problemas. }\end{array}$ & $\begin{array}{l}\text { Gravador; } \\
\text { Anotações do } \\
\text { professor; } \\
\text { Relatório de } \\
\text { aula. }\end{array}$ & $\begin{array}{l}\text { Foram apresentar e discutidos, a partir do texto "Uma } \\
\text { história da resolução de problemas no Brasil e no mundo", } \\
\text { da professora Onuchic, aspectos relacionados ao papel do } \\
\text { Problema nas aulas de matemática. Durante a discussão, } \\
\text { foram verificados aspectos do reconhecimento do papel } \\
\text { dos Problemas que os licenciandos verificaram em suas } \\
\text { experiências pregressas relacionadas ao ensino para a } \\
\text { resolução de Problemas e a partir da RP. }\end{array}$ \\
\hline 3 & $\begin{array}{l}\text { Reconhecer aspectos relacionados a técnicas de } \\
\text { resolução de Problemas. }\end{array}$ & $\begin{array}{l}\text { Gravador; } \\
\text { Anotações do } \\
\text { professor; Lista } \\
\text { de Problemas } \\
\text { resolvidos } \\
\text { aplicando } \\
\text { técnicas de } \\
\text { resolução. } \\
\end{array}$ & $\begin{array}{l}\text { Foram apresentados e discutidos, a partir do quadro } \\
\text { resumo do livro "A arte de resolver problemas" de George } \\
\text { Pólya, aspectos das técnicas para resolução de } \\
\text { Problemas. Durante a discussão verificamos indícios de } \\
\text { sentidos sobre "receitas" para a solução de qualquer } \\
\text { Problema por qualquer pessoa. }\end{array}$ \\
\hline 4 & $\begin{array}{l}\text { Reconhecer aspectos relacionados ao Problema como } \\
\text { desencadeador de aprendizagem para o planejamento das } \\
\text { práticas pedagógicas. }\end{array}$ & $\begin{array}{l}\text { Gravador; } \\
\text { Anotações do } \\
\text { professor; } \\
\text { Relatório de } \\
\text { aula. }\end{array}$ & $\begin{array}{l}\text { Os licenciandos foram convidados a apresentar uma } \\
\text { solução para a SDA intitulada "Carta Caitité", do professor } \\
\text { Moura, e foram discutidos aspectos de seu eventual uso } \\
\text { em sala de aula. Buscou-se verificar, entre outros, } \\
\text { aspectos comparativos entre a ideia de Problema da } \\
\text { proposta e os aspectos discutidos nos encontros } \\
\text { anteriores. }\end{array}$ \\
\hline 5 & $\begin{array}{l}\text { Reconhecer aspectos relacionados ao Problema como } \\
\text { desencadeador de aprendizagem para o planejamento das } \\
\text { práticas pedagógicas. }\end{array}$ & $\begin{array}{l}\text { Gravador; } \\
\text { Anotações do } \\
\text { professor; } \\
\text { Relatório de } \\
\text { aula. }\end{array}$ & $\begin{array}{l}\text { Continuamos a discussão sobre a potencialidade de } \\
\text { planejamento da aula a partir da Carta Caitité, tratando } \\
\text { também de ideias sobre propostas tradicionais para o } \\
\text { ensino do conceito matemático envolvido (Sistema de } \\
\text { numeração); foram tratados aspectos sobre a história dos } \\
\text { sistemas de numeração. Foi feita a uma síntese coletiva }\end{array}$ \\
\hline
\end{tabular}




\begin{tabular}{|c|c|c|c|}
\hline & & & $\begin{array}{l}\text { do movimento que tratou de uma formalização do conceito } \\
\text { e do eventual uso da proposta em sala de aula. }\end{array}$ \\
\hline 6 & $\begin{array}{l}\text { Reconhecer a importância da história da matemática para } \\
\text { a elaboração de Problemas de matemática voltados ao } \\
\text { ensino de conceitos. }\end{array}$ & $\begin{array}{l}\text { Gravador; } \\
\text { Anotações do } \\
\text { professor; } \\
\text { Relatório de } \\
\text { aula. }\end{array}$ & $\begin{array}{l}\text { Realizamos estudo, a partir de textos de história da } \\
\text { matemática, adaptados de referências como Eves, Boyer } \\
\text { e Roque, a respeito da história do conceito de equações, } \\
\text { que deveria subsidiar a proposta do encontro seguinte. Foi } \\
\text { tratado também de verificar como os licenciandos } \\
\text { proporiam a realização de uma aula que tivesse como } \\
\text { objetivo ensinar o conceito de equações ("como você } \\
\text { ensinaria o conceito de equação a uma turma do } 7^{\circ} \text { ano } \\
\text { do Ensino Fundamental?"). }\end{array}$ \\
\hline 7 & $\begin{array}{l}\text { Reconhecer aspectos relacionados ao Problema como } \\
\text { desencadeador de aprendizagem, no planejamento das } \\
\text { práticas pedagógicas. }\end{array}$ & $\begin{array}{l}\text { Gravador; } \\
\text { Anotações do } \\
\text { professor; } \\
\text { Relatório de } \\
\text { aula. }\end{array}$ & $\begin{array}{l}\text { Jogamos o "jogo de adivinhação", que traz o conceito de } \\
\text { equação polinomial do primeiro grau. Foram discutidos } \\
\text { aspectos histórico-matemáticos envolvidos na SDA e na } \\
\text { sua solução. }\end{array}$ \\
\hline 8 & $\begin{array}{l}\text { Reconhecer aspectos relacionados ao Problema como } \\
\text { desencadeador de aprendizagem para o planejamento das } \\
\text { práticas pedagógicas. }\end{array}$ & $\begin{array}{l}\text { Gravador; } \\
\text { Anotações do } \\
\text { professor; } \\
\text { Relatório de } \\
\text { aula. } \\
\end{array}$ & $\begin{array}{l}\text { Foram discutidos aspectos sobre as potencialidades de } \\
\text { ensino do conceito matemático no "jogo de adivinhação" } \\
\text { (equações); Foi feita a síntese coletiva da formalização do } \\
\text { conceito e dos aspectos relacionados às possibilidades de } \\
\text { práticas docentes a partir da proposta do jogo. }\end{array}$ \\
\hline 9 & $\begin{array}{l}\text { Realizar pesquisa da história do conceito objeto da } \\
\text { regência de estágio. }\end{array}$ & $\begin{array}{l}\text { Gravador; } \\
\text { Anotações do } \\
\text { professor; } \\
\text { Relatório de } \\
\text { aula. }\end{array}$ & $\begin{array}{l}\text { Os licenciandos foram convidados a realizar o estudo de } \\
\text { aspectos da história da matemática relacionados aos } \\
\text { conceitos que seriam objeto da regência de cada } \\
\text { integrante dos subgrupos. }\end{array}$ \\
\hline 10 & $\begin{array}{l}\text { Realizar pesquisa da história do conceito e planejamento } \\
\text { da regência de estágio. }\end{array}$ & $\begin{array}{l}\text { Gravador; } \\
\text { Anotações do } \\
\text { professor; } \\
\text { Relatório de } \\
\text { aula. } \\
\end{array}$ & $\begin{array}{l}\text { Continuação do estudo da história dos conceitos objeto da } \\
\text { regência de cada integrante dos subgrupos e elaboração } \\
\text { de planejamento da regência de estágio. }\end{array}$ \\
\hline 11 a 15 & Apresentar resultados da regência. & $\begin{array}{l}\text { Gravador; } \\
\text { Anotações do } \\
\text { professor; } \\
\text { Relatório. }\end{array}$ & $\begin{array}{l}\text { Foram feitas apresentações das propostas de regência } \\
\text { dos licenciandos, sendo um encontro para apresentação } \\
\text { de cada um dos } 5 \text { subgrupos. }\end{array}$ \\
\hline 16 a 19 & $\begin{array}{l}\text { Realizar avaliação e cumprimento das rotinas } \\
\text { administrativas da disciplina }\end{array}$ & $\begin{array}{l}\text { Anotações do } \\
\text { professor; } \\
\text { Relatório. }\end{array}$ & $\begin{array}{l}\text { Avaliação da disciplina; Relatório de estágio } \\
\text { supervisionado. }\end{array}$ \\
\hline
\end{tabular}

Fonte: Elaborado pelo autor 
No capítulo 4, mais precisamente no subitem 4.1, quando nos deteremos para a análise dos dados sobre os sentidos pessoais iniciais dos licenciandos, voltaremos a tratar de aspectos gerais dessa etapa exploratória que precedeu o experimento formativo.

\subsubsection{Sujeitos do experimento formativo}

Após aquela etapa anterior ao experimento formativo, pudemos inferir indícios de sentidos pessoais iniciais de sete licenciandos que foram, então, convidados a participar do experimento formativo que foi realizado durante o segundo semestre letivo de 2017 e também foi contextualizado pelas aulas das disciplinas de Práticas de Ensino. Novamente, o contexto de realização da disciplina da grade curricular do curso resultou, como era esperado, na matrícula de outros alunos, além dos sete que destacamos. Em respeito a princípios éticos e à nossa atuação como professor e como pesquisador, a todos os licenciandos matriculados foram apresentadas as características do projeto e estendido o convite à participação, mediante assinatura de termo de compromisso livre e esclarecido, foi ofertada a mesma formação, intencionalmente organizada para o estudo do papel do Problema na organização do ensino, mas, para efeitos dos resultados desta pesquisa, a investigação sobre o movimento dos sentidos pessoais remetem à formação específica daqueles sete licenciandos selecionados.

Participaram do experimento formativo as licenciandas que identificaremos por RPG, JZM, DFS e PNL e os licenciandos aos quais atribuímos nos referimos por TLL, ISC e MGO. Destes sete licenciandos, três (MGO, ISC e TLL) relataram que já exerciam, durante a realização das disciplinas, atividade remunerada relacionada à docência, sendo que MGO indicou atuar como professor no contexto do estágio remunerado em uma empresa, ISC indicou que atuava como "professor eventual" 20 e TLL atuava como professor no contexto da educação profissionalizante em escola técnica.

\footnotetext{
${ }^{20}$ Na rede pública de educação do Estado de São Paulo, o "professor eventual" é o professor que assume eventualmente as aulas no impedimento temporário do professor titular, como em faltas ou afastamentos breves em que as aulas não são atribuídas a outro professor titular. Em outras redes, o professor eventual é comumente chamado de "professor substituto".
} 
Já a licencianda JZM possuía vínculo com o PIBID ${ }^{21}$, o que implica a realização de algumas intervenções que poderiam ser consideradas como regência de aula. As demais licenciandas, à época do experimento, só haviam tido a experiência de organizar aulas no contexto da regência de estágio supervisionado.

RPG tinha 21 anos à época do experimento formativo, era solteira e vivia com os pais. Indicou que ingressou no curso de licenciatura em matemática por afinidade com a matéria durante a educação básica e por se identificar com a carreira docente. Classificava como "boa" a formação que vinha recebendo no curso e acreditava que a mesma seria suficiente para sua futura atuação como professora. Não exercia atividade remunerada e ainda não havia atuado em sala de aula, para além das experiências com o estágio supervisionado.

JZM era casada e contava 48 anos naquele momento. Ingressou na licenciatura como um desafio autoimposto de realizar uma graduação e em uma área como a matemática. Morava com o marido e o filho. Entendia que a formação que havia recebido até então no curso era "boa", mas que sentia falta de mais "atividades práticas". Entendia que, por isso, ela passou a integrar o PIBID e que essa experiência contribuiu muito para sua formação como professora. Também não exercia atividade remunerada, mas era beneficiária de programas de assistência estudantil.

DFS tinha 20 anos, era solteira e morava com os pais. Estudou em instituição privada de ensino e ingressou no curso de licenciatura também por afinidade com a disciplina durante a educação básica. Também não atuava profissionalmente e suas experiências em sala de aula, além da vivência como estudante, resumiam-se à realização dos estágios supervisionados. Manifestou intenção de prosseguir os estudos em nível de pós-graduação para uma especialização na área (da matemática). Afirmava que entendia que a formação matemática que vinha recebendo no curso até aquele momento era "bastante consistente", mas que a "parte pedagógica" deixava a desejar. Complementou que, inclusive, percebia um ambiente "contraditório" no curso, já que os professores "da parte pedagógica" diziam uma coisa, mas nas aulas esses mesmos professores contradiziam o discurso.

${ }^{21}$ O Programa Institucional de Bolsas de Iniciação à Docência (PIBID). 
PNL era casada e tinha 24 anos à época da formação. Manifestou ter ingressado no curso por ser uma graduação em matemática, mas pela formação matemática em si e não para ser professora. Afirmava que não conseguia imaginar-se como professora e que não queria seguir a carreira docente. Trabalhava em uma instituição financeira (um banco comercial) e não tinha filhos. Classificou sua formação no curso até ali como "mais ou menos", enfatizando críticas a algumas disciplinas que pressupunham "pré-requisitos" que não eram ensinados pelos professores.

TLL era casado e não informou a idade na ocasião. Atuava como professor na rede pública, em cursos profissionalizantes. Manifestou que não tinha filhos. Indicou ainda uma possível "desesperança" sobre o que supunha ser o futuro da educação. Morava com a esposa e afirmou estar em busca de aprimoramento em sua formação como uma das principais razões para seu ingresso no curso de licenciatura. Também considerava "boa" a formação que vinha recebendo no curso até então.

ISC também era casado e tinha 31 anos à época da formação. Atuava como professor eventual em uma escola da rede pública. Informou que considerava "boa" a formação que já tinha experimentado durante o curso até ali e que esta contribuía sensivelmente para sua atuação como professor eventual na escola. Ingressou no curso, a exemplo de outros colegas, por afinidade com a matéria durante a educação básica. Mostrou-se, no decorrer do curso, um aluno tímido e de poucas palavras, mas bastante participativo e coerente na realização das propostas apresentadas.

MGO tinha 29 anos à época e vivia uma união estável na ocasião do experimento. Trabalhava como representante comercial e como "professor-estagiário" (com contrato de estágio remunerado) junto a uma empresa privada. Ingressou no curso por afinidade com a matemática enquanto estudante e por enxergar na carreira docente um meio para ajudar as pessoas. Manifestou especial apreço pela educação de jovens e adultos e indicou que considerava a formação recebida no curso até aquele momento como "deficitária" nesse aspecto, afirmando que ensinar para esse público (de jovens e adultos) não é a mesma coisa que ensinar para alunos em idade regular e defendendo que o curso deveria ter uma formação mais específica para aquele público. 


\subsubsection{Procedimentos do experimento formativo}

Esses sete licenciandos que foram convidados a participar do nosso experimento formativo foram aqueles que indicaram, durante a etapa apresentada no subitem 3.1.1, sobretudo a partir dos relatórios de regência de estágio supervisionado, a adoção de proposições que atribuíam ao Problema algum papel na organização do ensino. Os demais licenciandos ou concluíram as exigências de estágio supervisionado (de modo que não cursariam mais as disciplinas de Prática de Ensino) ou fizeram proposições que tratavam de apresentar aspectos lógico-formais do conceito a ser ensinado, sem fazer referência ao uso de Problemas.

No experimento formativo, visando analisar o movimento dos sentidos pessoais dos licenciandos sobre o papel do Problema, propusemos Situações Desencadeadoras de Aprendizagem da docência, cuja essência, ou seja, cujos problemas desencadeadores de aprendizagem, estivessem impregnados da necessidade de os próprios licenciandos planejarem suas regências de estágio supervisionado segundo os pressupostos da AOE. Para tanto, estabelecemos que os licenciandos deveriam planejar as regências a partir da compreensão do conceito de Problema Desencadeador de Aprendizagem.

A seguir apresentamos o quadro 4 que resume o panorama geral dos encontros realizados no experimento formativo. 
Quadro 4: Resumo encontros do experimento formativo $\left(2^{\circ}\right.$ semestre de 2017$)$

\begin{tabular}{|c|c|c|c|c|}
\hline $\mathbf{N}^{\circ}$ & Objetivos & $\begin{array}{l}\text { Instrumentos } \\
\text { de coleta de } \\
\text { dados }\end{array}$ & Ações & Operações \\
\hline 1 & $\begin{array}{l}\text { Apresentar objetivos da pesquisa, o } \\
\text { professor e conhecer os licenciandos. } \\
\text { Levantar indícios dos sentidos sobre } \\
\text { Problema. }\end{array}$ & $\begin{array}{l}\text { Gravador; } \\
\text { Anotações do } \\
\text { professor. }\end{array}$ & $\begin{array}{l}\text { Foram apresentados os objetivos e } \\
\text { aspectos gerais da pesquisa e o modo } \\
\text { como a mesma se articulava com a } \\
\text { disciplina do curso; Foram discutidos } \\
\text { aspectos relacionados ao papel dos } \\
\text { Problemas na formação dos licenciandos e } \\
\text { sobre a percepção deles e dos novos } \\
\text { alunos sobre esse papel em suas próprias } \\
\text { práticas pedagógicas. }\end{array}$ & $\begin{array}{l}\text { - Discussão: O que significa utilizar } \\
\text { Problemas nas aulas? Qual o papel } \\
\text { do Problema nas aulas de } \\
\text { matemática? Como você proporia } \\
\text { uma aula que devesse utilizar } \\
\text { Problemas na educação básica? }\end{array}$ \\
\hline 2 & $\begin{array}{l}\text { Discutir compreensões iniciais acerca } \\
\text { do que seria um Problema adequado } \\
\text { a ser utilizado em uma aula de } \\
\text { matemática. }\end{array}$ & $\begin{array}{l}\text { Gravador; } \\
\text { Anotações do } \\
\text { professor; Plano } \\
\text { de r aula } \\
\text { elaborado pelos } \\
\text { alunos. }\end{array}$ & $\begin{array}{l}\text { Foi solicitado aos licenciandos que } \\
\text { elaborassem um pequeno "Plano de aula" } \\
\text { que visasse ensinar o conceito de Juros } \\
\text { Simples a alunos (fictícios) do primeiro ano } \\
\text { do Ensino Médio de uma turma de } \\
\text { Educação de Jovens e Adultos; foram } \\
\text { discutir aspectos gerais das propostas } \\
\text { apresentadas. }\end{array}$ & $\begin{array}{l}\text { - Plano de aula: Juros Simples. } \\
\text { - Discussão a respeito do conceito de } \\
\text { Juros Simples. } \\
\text { - Discussão a respeito das propostas } \\
\text { de ensino do conceito. } \\
\text { - Discussão a respeito do papel do } \\
\text { Problema nas propostas } \\
\text { apresentadas (São Problemas ou } \\
\text { não são? Remetem ao conceito ou } \\
\text { não?) }\end{array}$ \\
\hline 3 & $\begin{array}{l}\text { Reconhecer a importância da história } \\
\text { da matemática para a elaboração de } \\
\text { Problemas de matemática voltados } \\
\text { ao ensino de conceitos. }\end{array}$ & $\begin{array}{l}\text { Gravador; } \\
\text { Anotações do } \\
\text { professor. }\end{array}$ & $\begin{array}{l}\text { Foi realizado estudo, a partir de textos } \\
\text { adaptados de história da matemática sobre } \\
\text { o conceito de Juros; depois foi realizado um } \\
\text { debate comparativo entre as propostas } \\
\text { apresentadas na aula anterior e eventuais } \\
\text { alterações considerando os estudos } \\
\text { históricos realizados. }\end{array}$ & $\begin{array}{l}\text { - Estudo de textos a respeito da } \\
\text { história factual do conceito. } \\
\text { - Retomada das proposições } \\
\text { apresentadas nos Planos de aula. } \\
\text { - Reelaboração das propostas } \\
\text { incluindo aspectos da HM. }\end{array}$ \\
\hline 4 & $\begin{array}{l}\text { Reconhecer a importância da história } \\
\text { da matemática para a elaboração de } \\
\text { Problemas de matemática voltados } \\
\text { ao ensino de conceitos. }\end{array}$ & $\begin{array}{l}\text { Gravador; } \\
\text { Anotações do } \\
\text { professor. }\end{array}$ & $\begin{array}{l}\text { Foi realizado estudo, a partir de textos } \\
\text { adaptados de história da matemática sobre } \\
\text { o conceito de Logaritmo; depois foi } \\
\text { realizado um debate acerca de estratégias } \\
\text { tradicionais para o ensino do conceito de } \\
\text { logaritmos a partir da provocação "como } \\
\text { você ensinaria o conceito de logaritmos a } \\
\text { uma turma do } 1^{\circ} \text { ano do Ensino Médio?". }\end{array}$ & $\begin{array}{l}\text { - Estudo de textos a respeito da } \\
\text { história factual do conceito. } \\
\text { - Discussão: Como foi o ensino de } \\
\text { logaritmos que vocês vivenciaram até } \\
\text { hoje? Como vocês proporiam o } \\
\text { ensino do conceito de Logaritmos? }\end{array}$ \\
\hline
\end{tabular}




\begin{tabular}{|c|c|c|c|c|c|}
\hline 5 & $\begin{array}{l}\text { Reconhecer aspectos relacionados } \\
\text { ao Problema como desencadeador } \\
\text { de aprendizagem para o } \\
\text { planejamento das práticas } \\
\text { pedagógicas. }\end{array}$ & $\begin{array}{l}\text { Gravador; } \\
\text { Anotações } \\
\text { professor; } \\
\text { Relatório } \\
\text { aula. }\end{array}$ & & $\begin{array}{l}\text { Foi apresentado para solução SDA } \\
\text { representada pelo Problema de João } \\
\text { Napião, que elaboramos para o ensino do } \\
\text { conceito de Logaritmos. Foi feita a } \\
\text { resolução da situação e foi discutido o } \\
\text { aspecto da necessidade de apropriação } \\
\text { conceitual suscitada pelo PDA, bem como } \\
\text { sobre a potencialidade da SDA para o } \\
\text { ensino em comparação com as } \\
\text { proposições tradicionais para o ensino do } \\
\text { mesmo conceito levantadas no encontro } \\
\text { anterior. }\end{array}$ & $\begin{array}{l}\text { - Estudo de textos a respeito da } \\
\text { história factual do conceito. } \\
\text { - Apresentação e resolução da SDA. } \\
\text { - Discussão a respeito do conceito de } \\
\text { Logaritmos. } \\
\text { - Discussão a respeito da proposta } \\
\text { para o ensino do conceito. } \\
\text { - Discussão a respeito do papel do } \\
\text { Problema contido na SDA (É } \\
\text { Problemas ou não? Remete ao } \\
\text { conceito ou não?) }\end{array}$ \\
\hline 6 & $\begin{array}{l}\text { Reconhecer aspectos relacionados } \\
\text { ao Problema como desencadeador } \\
\text { de aprendizagem para o } \\
\text { planejamento das práticas } \\
\text { pedagógicas. }\end{array}$ & $\begin{array}{l}\text { Gravador; } \\
\text { Anotações } \\
\text { professor; } \\
\text { Relatório } \\
\text { aula. }\end{array}$ & $\begin{array}{l}\text { do } \\
\text { de }\end{array}$ & $\begin{array}{l}\text { Demos continuidade nas discussões sobre } \\
\text { a potencialidade de uso da SDA do João } \\
\text { Napião (para o ensino de Logaritmos); Foi } \\
\text { dada ênfase nos aspectos históricos } \\
\text { relacionados à elaboração da situação (e } \\
\text { não à aprendizagem do conceito em si); foi } \\
\text { feita a síntese coletiva do movimento de } \\
\text { solução e sobre os aspectos relacionados } \\
\text { à formação do professor envolvidos. }\end{array}$ & $\begin{array}{l}\text { - Discussão a respeito do papel do } \\
\text { Problema contido na SDA (É } \\
\text { Problemas ou não? Remete ao } \\
\text { conceito ou não?) } \\
\text { - - Discussão a respeito da } \\
\text { importância da HM para a elaboração } \\
\text { da SDA e do PDA. }\end{array}$ \\
\hline 7 & $\begin{array}{l}\text { Reconhecer aspectos relacionados } \\
\text { ao Problema como desencadeador } \\
\text { de aprendizagem para o } \\
\text { planejamento das práticas } \\
\text { pedagógicas. }\end{array}$ & $\begin{array}{l}\text { Gravador; } \\
\text { Anotações } \\
\text { professor; } \\
\text { Relatório } \\
\text { aula. }\end{array}$ & & $\begin{array}{l}\text { Retomamos como os sujeitos da pesquisa } \\
\text { e apresentamos inicialmente para os novos } \\
\text { alunos o "jogo de adivinhação" para } \\
\text { subsidiar uma discussão sobre aspectos } \\
\text { histórico-matemáticos envolvidos na SDA e } \\
\text { na sua solução, comparando percepções } \\
\text { acerca do jogo e elementos de história da } \\
\text { matemática. }\end{array}$ & $\begin{array}{l}\text { - Estudo de textos a respeito da } \\
\text { história factual do conceito } \\
\text { (equações). } \\
\text { - Apresentação e resolução da SDA } \\
\text { (jogo da adivinhação). } \\
\text { - Discussão a respeito do conceito de } \\
\text { equação. } \\
\text { - Discussão a respeito das propostas } \\
\text { para o ensino do conceito: } \\
\text { tradicionais x SDA (jogo). } \\
\text { - Discussão a respeito do papel do } \\
\text { Problema contido na SDA (É } \\
\text { Problemas ou não? Remete ao } \\
\text { conceito ou não?) }\end{array}$ \\
\hline 8 & $\begin{array}{l}\text { Reconhecer contradições entre a } \\
\text { "tipificação" de Problemas e o } \\
\text { objetivo de desenvolver a capacidade } \\
\text { de resolver Problemas }\end{array}$ & $\begin{array}{l}\text { Gravador; } \\
\text { Anotações } \\
\text { professor; } \\
\text { Relatório } \\
\text { aula. }\end{array}$ & & $\begin{array}{l}\text { A partir de resumo dos "tipos" de Problema } \\
\text { apresentados por Dante }(1998,2009) \\
\text { discutimos aspectos relacionados ao } \\
\text { objetivo de desenvolver a capacidade de } \\
\text { resolver Problemas e a apresentação de }\end{array}$ & $\begin{array}{l}\text { Apresentação do texto mediador } \\
\text { "tipos de Problemas" e relação de } \\
\text { Problemas a serem classificados. }\end{array}$ \\
\hline
\end{tabular}




\begin{tabular}{|c|c|c|c|c|}
\hline & & & $\begin{array}{l}\text { Problemas agrupados por "tipos". Foi } \\
\text { solicitado que os licenciandos } \\
\text { "tipificassem" Problemas recebidos em } \\
\text { impresso e avaliassem aspectos } \\
\text { relacionados a tal tipificação, como a } \\
\text { indicação de técnicas de resolução. }\end{array}$ & $\begin{array}{l}\text { - Discussão: Como classificar os } \\
\text { Problemas segundo "tipos" contribui } \\
\text { para a organização do ensino? } \\
\text { - Discussão: Técnicas de resolução } \\
\text { de Problemas ("Heurísticas") }\end{array}$ \\
\hline 9 & $\begin{array}{l}\text { Reconhecer a importância da } \\
\text { elaboração ou adaptação de PDA }\end{array}$ & $\begin{array}{l}\text { Gravador; } \\
\text { Anotações do } \\
\text { professor; } \\
\text { Relatório de } \\
\text { aula. }\end{array}$ & $\begin{array}{l}\text { Propusemos, a partir da consulta a livros } \\
\text { didáticos, a busca por Problemas "prontos" } \\
\text { para introdução de uma aula de } \\
\text { matemática sobre tema escolhido pelos } \\
\text { licenciandos em grupo; Foi enfatizada a } \\
\text { necessidade de avaliar criticamente o } \\
\text { potencial desses Problemas em relação } \\
\text { aos conceitos envolvidos em sua solução } \\
\text { enquanto potenciais desencadeadores de } \\
\text { aprendizagem. }\end{array}$ & $\begin{array}{l}\text { - Análise de Problemas propostos em } \\
\text { livros didáticos. } \\
\text {-Discussão: o livro didático é recurso } \\
\text { didático ou "muleta"? Como os } \\
\text { Problemas presentes nos livros } \\
\text { didáticos são abordados? E como } \\
\text { poderiam ser. } \\
\text { - Proposição: escolher um Problema } \\
\text { em um livro didático e } \\
\text { adaptar/reelaborar para ensinar um } \\
\text { conceito a partir dele. }\end{array}$ \\
\hline 10 & $\begin{array}{l}\text { Reconhecer a importância da } \\
\text { elaboração ou adaptação de PDA }\end{array}$ & $\begin{array}{l}\text { Gravador; } \\
\text { Anotações do } \\
\text { professor; } \\
\text { Relatório de } \\
\text { aula. }\end{array}$ & $\begin{array}{l}\text { Continuamos a proposta do encontro } \\
\text { anterior, buscando ainda a adaptação ou } \\
\text { elaboração de novos Problemas } \\
\text { relacionados ao mesmo conceito } \\
\text { pesquisado no encontro anterior, a partir de } \\
\text { aspectos estudados durante o curso. }\end{array}$ & $\begin{array}{l}\text { - Proposição: escolher um Problema } \\
\text { em um livro didático e e } \\
\text { adaptar/reelaborar para ensinar um } \\
\text { conceito a partir dele. }\end{array}$ \\
\hline $\begin{array}{l}11 \\
a \\
15\end{array}$ & Apresentar resultados da regência. & $\begin{array}{l}\text { Gravador; } \\
\text { Anotações do } \\
\text { professor; } \\
\text { Relatório de } \\
\text { estágio } \\
\text { supervisionado. }\end{array}$ & $\begin{array}{l}\text { Foram feitas apresentações das propostas } \\
\text { de regência dos licenciandos, sendo um } \\
\text { encontro para apresentação de cada um } \\
\text { dos } 5 \text { subgrupos. }\end{array}$ & $\begin{array}{l}\text { - Seminários para apresentação do } \\
\text { que foi realizado durante o estágio } \\
\text { nas práticas de regência. }\end{array}$ \\
\hline $\begin{array}{l}16 \\
a \\
19\end{array}$ & $\begin{array}{l}\text { Realizar avaliação e cumprimento } \\
\text { das rotinas administrativas da } \\
\text { disciplina }\end{array}$ & $\begin{array}{l}\text { Anotações do } \\
\text { professor; } \\
\text { Relatório de } \\
\text { estágio } \\
\text { supervisionado. }\end{array}$ & $\begin{array}{l}\text { Foram feitas discussões acerca das } \\
\text { opções dos licenciandos sobre aspectos } \\
\text { relevantes no movimento de organização } \\
\text { das próprias regências e sobre o uso ou } \\
\text { não de Problemas em algum momento do } \\
\text { estágio; } \\
\text { Foi realizada avaliação da disciplina; } \\
\text { Relatório de estágio supervisionado e } \\
\text { cumprimento das formalidades } \\
\text { administrativas da disciplina. }\end{array}$ & $\begin{array}{l}\text { - Rotinas administrativas para } \\
\text { documentação de estágio. } \\
\text { - Discussão: Quais os resultados dos } \\
\text { estudos realizados durante o } \\
\text { semestre? Qual o papel do Problema } \\
\text { na sua regência de estágio? }\end{array}$ \\
\hline
\end{tabular}

Fonte: Elaborado pelo autor 
É importante destacar, ainda, que outros aspectos do experimento formativo estão também apresentados no capítulo 4 , a fim de aproximar sua apresentação da análise que apresentaremos naquele capítulo. Os dados coletados a partir desses encontros estão organizados segundo categorias de análise que remetem a isolados e episódios, conforme as proposições de Caraça (1989) e Moura (2000). Os aspectos da organização e da apresentação desses dados em nossa análise, bem como demais considerações sobre o método estão apresentadas no subcapítulo a seguir.

\subsection{Aspectos metodológicos da análise de dados}

Os dados analisados em nossa pesquisa foram produzidos por meio do experimento formativo e coletados por meio de instrumentos específicos, conforme já indicamos, especificamente nos quadros 3 e 4 . Os dados referentes às gravações de aula foram devidamente transcritos. Como verificamos nos referidos quadros, também constituíram instrumentos de coleta para a análise que apresentaremos mais adiante, um caderno de campo onde foram lançados apontamentos feitos pelo professor, no momento da realização de cada proposta, fichas de registro de tarefas e relatórios de aula realizados pelos licenciandos, bem como os relatórios finais de estágio supervisionado. A fim de organizar os dados, definimos a seguinte categorização:

Quadro 5: Categorização de dados

\begin{tabular}{|l|l|l|}
\hline \multicolumn{1}{|c|}{ Dado } & \multicolumn{1}{|c|}{ Contexto } & Sigla \\
\hline Transcrição de áudio & $\begin{array}{l}\text { Falas dos licenciandos nos momentos de socialização } \\
\text { (coletivamente), que remetem a considerações } \\
\text { discutidas em grupo }\end{array}$ & TAC \\
\hline Transcrição de áudio & $\begin{array}{l}\text { Falas dos licenciandos ou do professor nos encontros } \\
\text { durante a realização das tarefas, que remetem a } \\
\text { considerações individuais }\end{array}$ & TAI \\
\hline $\begin{array}{l}\text { Registro escrito de tarefa } \\
\text { realizada em grupo } \\
\text { (coletivamente) }\end{array}$ & $\begin{array}{l}\text { Considerações presentes nos relatórios realizados em } \\
\text { grupo. }\end{array}$ & RTC \\
\hline $\begin{array}{l}\text { Registro escrito de tarefa } \\
\text { realizada individualmente }\end{array}$ & $\begin{array}{l}\text { Considerações ou aspectos da resolução individual } \\
\text { presentes nos relatórios de resolução de SDA. }\end{array}$ & RTI \\
\hline
\end{tabular}




\begin{tabular}{|l|l|l|}
\hline $\begin{array}{l}\text { Registro realizado em } \\
\text { relatório de estágio. }\end{array}$ & $\begin{array}{l}\text { Aspectos apresentados pelos licenciandos em seus } \\
\text { relatórios de estágio supervisionado }\end{array}$ & RES \\
\hline
\end{tabular}

Fonte: Elaborado pelo autor

Também, a fim de organizar as referências, indicaremos a etapa à qual o dado se refere da seguinte forma: os dados que remeterem a eventos realizados na etapa anterior ao experimento formativo indicaremos como PEF (pré-experimento formativo) e aqueles que ocorreram no contexto do experimento formativo serão indicadas por EF.

Da mesma forma o encontro que contextualiza o dado, quando for o caso, será indicado pela letra $E$ seguida do número de ordem do encontro. Assim, por exemplo, um dado que remeta a um evento contextualizado no primeiro encontro será indicado por E1, no segundo encontro por E2, no terceiro por E3, e assim sucessivamente. Apenas em relação aos registros realizados pelos licenciandos nos relatórios de estágio, por seu caráter sintético não relacionado a algum encontro específico, não há referência a um encontro.

A análise evidencia os momentos de formação que indiciam o movimento dos sentidos atribuídos pelas licenciandas RPG, JZM, DFS e PNL e pelos licenciandos TLL, ISC e MGO ao conceito de Problema e ao seu papel nas aulas de matemática.

Durante o experimento formativo, os licenciandos foram distribuídos em grupos com quatro participantes cada, mas não a partir de um agrupamento por afinidade. A organização ocorreu da seguinte forma: os licenciandos TLL, ISC e MGO participaram do mesmo grupo com mais um licenciando, pelo fato de os Problemas utilizados por eles na regência de estágio da primeira etapa, como indicaremos no item 4.1, terem remetido às necessidades históricas do conceito que pretendiam ensinar. Esse grupo, identificaremos como Grupo X, sendo a referenciado, quando for o caso por GX; PNL e JZM participaram de outro grupo com mais dois licenciandos, por terem indicado como Problema, na regência final da primeira etapa, um jogo. Esse grupo será referenciado como Grupo $Y$, abreviado como GY; e, por fim, RPG e DFS ficaram com outros dois licenciandos em um grupo, em razão de as duas terem apresentado nas regências Problemas que tinham o intuito ensinar um conceito a partir de uma situação que consideraram emergente do cotidiano. Esse será o Grupo Z, ou simplesmente GZ. Ficou estabelecido, ainda, que essa organização seria mantida até o final do semestre letivo (e, consequentemente, do 
experimento formativo). A referência, de forma análoga ao que estabelecemos para os dados produzidos coletivamente na etapa exploratória pré-experimento formativo, indica o tipo de dado sucedido da indicação do grupo. Por exemplo, TAC-GX indica a transcrição de uma fala de um licenciando que representa as discussões realizadas no contexto do grupo X.

As citações, então, remetem à seguinte organização: indicação do licenciando e/ou do grupo, indicação da sigla do dado citado separada por um traço do encontro em que ocorreu, e etapa que contextualiza a indicação. Dessa forma, por exemplo, a indicação (RPG, TAI-E1, PEF) indica uma transcrição de áudio referente a fala individual da licencianda RPG, coletado por meio da gravação realizada no encontro 1 (um) durante a etapa que precedeu o experimento formativo. Já, como outro exemplo, (MGO, TACGX-E2, EF) remete à transcrição de áudio referente a fala do licenciando MGO durante a apresentação das discussões realizadas no contexto do grupo $X$ no segundo encontro durante o experimento formativo.

Apesar de o movimento formativo aqui evidenciado enfatizar apenas esses sete licenciandos apresentados no subitem 3.1.2, optamos por representar, nas transcrições de diálogos e debates, a fim de não comprometer a interpretação, também as eventuais falas e considerações de outros licenciandos, indicados por referências diversas das atribuídas aos sujeitos de nossa pesquisa, respeitando os princípios éticos inerentes à pesquisa, como o sigilo de identidade, reiterando que todos os licenciandos assinaram o TCLE que nos autoriza a tal opção.

Considerando a impossibilidade de acompanhar toda a realidade universal, adotamos o conceito de isolado, apresentado por Caraça (1989), para a organização geral da análise e a apresentação dos resultados. Compreendemos que a ideia de isolado seja adequada à análise do movimento de formação acompanhado durante o experimento formativo, pois, de acordo com Caraça (1989), a ciência é constituída pela explicação das relações entre os fenômenos do mundo físico e a humanidade, ou seja, superando aquilo que caracteriza o senso comum, em que as conclusões sobre os fenômenos da natureza se resumem a descrições subjetivas de cada indivíduo sobre aquilo que observa, a ciência busca explicar esses fenômenos e suas relações com a 
humanidade de forma que tal explicação represente os seus aspectos em qualquer lugar social e momento histórico.

[...] vimos como o homem, na sua necessidade de lutar contra a Natureza e no seu desejo de a dominar, foi levado, naturalmente, à observação e estudo dos fenómenos, procurando descobrir as suas causas e o seu encadeamento. Os resultados desse estudo, lentamente adquiridos e acumulados, vão constituindo o que, no decurso dos séculos da vida consciente da Humanidade, se pode designar pelo nome de Ciência. (CARAÇA, 1989, p. 107, grifos no original).

Caraça (1989, p. 109), no entanto, alerta que "a ciência não tem, nem pode ter, como objetivo descrever a realidade tal como ela é". Entendemos essa ressalva do autor como coerente à compreensão histórico-cultural de que o conhecimento científico não é algo dado, pronto, mas o produto de uma produção em constante movimento. Caraça (1989, p. 110) defende ainda que a realidade é compreendida como aquilo que "a inteligência dos homens se esforça por compreender, o Mundo, no seu sentido mais largo", e que esta realidade a ser compreendida se divide em duas características fundamentais: a interdependência entre todas as coisas, como parte de uma mesma unidade; e o estado de permanente movimento de evolução.

Essas características da realidade determinam, de acordo com Caraça (1989), uma impossibilidade de se verificar, pela experimentação, todas as interdependências e fluências possíveis. Por isso, seria necessário que, no movimento de pesquisa que pretende produzir conhecimento científico, sejam destacados um conjunto de situações que representem a totalidade da realidade que se pretende estudar. Essas situações destacadas da realidade é o que o autor denomina isolado, em que se podemos verificar fatores que coloquem em evidência as interrelações e o desenvolvimento da realidade.

O isolado é, então, definido por Caraça como sendo "uma seção da realidade, nela recortada arbitrariamente" (CARAÇA, 1989, p. 112). Dessa forma, o isolado, para nós, evidencia no experimento formativo as unidades elementares que caracterizam, no contexto da análise subsidiada pelo arcabouço teórico e metodológico, o movimento de aprendizagem da docência. Durante esse movimento de aprendizagem da docência pudemos destacar isolados que indiciaram sentidos pessoais dos licenciandos sobre 0 conceito de Problema.

Na impossibilidade de abraçar, num único golpe, a totalidade do Universo, o observador recorta, destaca, dessa totalidade, um conjunto de seres e factos, 
abstraindo de todos os outros que com eles estão relacionados. A um tal conjunto daremos o nome de isolado (CARAÇA, 1989, p. 112)

O objetivo nos isolados que destacamos foi o de apresentar as situações em que verificamos indícios do movimento dos sentidos pessoais manifestados pelos licenciandos. Dos isolados, destacaremos episódios, conforme o entendimento de Moura (2000), segundo o qual estes são momentos do experimento formativo que evidenciam as contradições que podem promover a aprendizagem do conceito em estudo. Cedro (2008, p.112), define os episódios, também a partir da compreensão de Moura (2000), como sendo "aqueles momentos que apresentam coerência, consistência, originalidade, objetivação e são reveladores da natureza e da qualidade das ações dos indivíduos".

Considerando essa organização identificamos três isolados a partir dos quais apresentaremos, a partir do subcapítulo 4.2, nossa análise do movimento dos sentidos dos licenciandos.

$O$ isolado $A$ busca apresentar aspectos que remetem aos sentidos dos licenciandos sobre o protagonismo do Problema na organização da AOE. Desse isolado destacamos dois episódios sendo que o primeiro deles indica um reconhecimento da necessidade de que os PDA suscitem a necessidade de apropriação, pelos alunos, dos conceitos em estudo e, outro episódio, que trata da superação da proposição de Problemas "prontos"; $O$ isolado $B$, por sua vez, destaca o papel dos estudos de História da Matemática - HM na organização da atividade pedagógica bem como da influência desses estudos em relação à função do PDA na $\mathrm{AOE}$. Nesse isolado tratamos do episódio que relaciona a $\mathrm{HM}$ à essência da necessidade que levou a humanidade a constituir historicamente os conceitos a serem estudados; e, finalmente, o isolado $C$ em que discutimos as relações entre o significado de PDA produzido em uma perspectiva histórico-cultural e o movimento dos sentidos pessoais dos licenciandos sobre o papel do Problema na organização do ensino. Nesse último isolado identificamos os episódios que tratam das relações entre os sentidos dos licenciandos sobre o PDA e o planejamento das SDA na AOE bem como apresentamos aspectos sobre o uso de Problemas na regência de estágio em que há aproximações com o conceito de PDA.

Essa organização dos isolados e episódios está resumida na figura 7: 
Figura 7: Organização de Episódios e Isolados

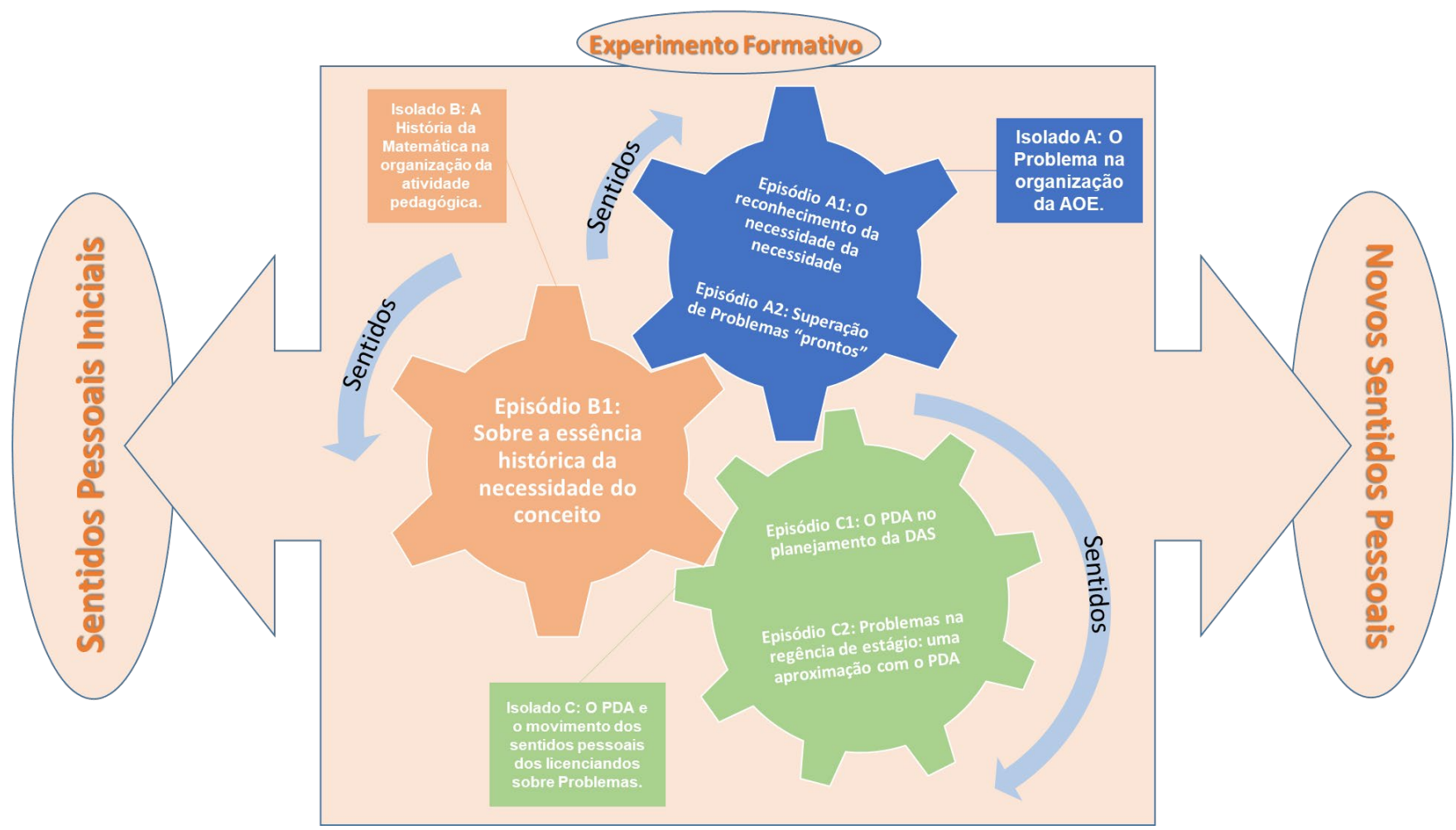

Fonte: Elaborado pelo autor

Importante destacar que os isolados foram indicados como A, B e C apenas como meio de referenciá-los, sem que isso implique uma organização linear do experimento, como procuramos destacar na figura 7 . Entendemos que o movimento dos sentidos sobre o papel dos Problemas nas práxis pedagógicas destacou, no contexto de todo o experimento formativo, os isolados e os respectivos episódios que apresentaremos no capítulo a seguir.

Assim, realizamos nossa análise dos dados, no contexto da THC e da teoria da atividade, que buscou promover um aspecto da aprendizagem da docência a partir do movimento dos sentidos pessoais sobre o conceito de Problema no contexto na formação inicial de professores. Dessa forma, nos deteremos no próximo capítulo à apresentação dos resultados de tal análise. 


\section{CAPÍTULO 4}

RELAÇÕES ENTRE CONCEITO DE PDA E O MOVIMENTO DOS SENTIDOS PESSOAIS NA FORMAÇÃO INICIAL DE PROFESSORES DE MATEMÁTICA 


\section{ReLAÇÕES ENTRE CONCEITO de PDA E O MOVIMENTO dOS SENTIDOS PESSOAIS NA FORMAÇÃO INICIAL DE PROFESSORES DE MATEMÁTICA}

É fundamental que, na prática da formação docente, o aprendiz de educador assuma que o indispensável pensar certo não é presente dos deuses nem se acha nos guias de professores que iluminados intelectuais escrevem desde o centro do poder, mas, pelo contrário, o pensar certo, que supera o ingênuo, tem que ser produzido pelo próprio aprendiz em comunhão com o professor formador.

Paulo Freire 22

Apresentado o nosso problema de pesquisa, os aspectos relacionados ao conceito de Problema e seu papel nas aulas de matemática e os aspectos teóricos e metodológicos que nos subsidiam, trataremos neste capítulo de apresentar a análise que, por sua vez, sustentará as conclusões que seguirão a este.

Coerentemente com a perspectiva teórica que subsidia esta análise, entendemos que a formação inicial de professores é um processo de aprendizagem e, como tal, se dá na atividade. A mesma fundamentação teórica nos autoriza a reconhecer que os sentidos são construtos teóricos que remetem à consciência individual e, portanto, são pessoais, de modo que, entendemos, não é possível "ensinar" sentidos. Da mesma forma, também não é possível "determinar" quais são os sentidos ou identificar de forma direta seu movimento. Todavia, compreendemos que a atividade orientadora de ensino se caracteriza como um movimento intencional em que motivos compreensíveis podem ser transformados em motivos eficazes, e, como vimos, a transformação de motivos está dialeticamente relacionada ao movimento dos sentidos pessoais. Por isso, o movimento formativo nos permite acompanhar indícios de que novos sentidos pessoais vão se constituindo à medida em que os motivos da atividade dos licenciandos vão se modificando.

Entendemos ser adequado iniciar apresentando o que pudemos reconhecer como sentidos pessoais iniciais dos licenciandos sobre o conceito de Problema e qual seria seu papel nas práticas docentes.

22 FREIRE, P. Pedagogia da autonomia: saberes necessários à prática educativa. São Paulo: Paz e Terra, 1996. (coleção Leitura). p. 18. 


\subsection{Sentidos Pessoais Iniciais sobre o papel do Problema nas aulas de matemática}

Como já indicamos, no subitem 3.1.1, os indícios sobre os sentidos pessoais iniciais dos licenciandos sobre o conceito de Problema foram coletados em um movimento que antecedeu nosso experimento formativo propriamente dito. De maneira geral, os licenciandos demonstravam apropriações do senso comum em relação aos Problemas. Alguns licenciandos informaram já terem lido alguns textos que faziam referência ao uso de Problemas nas aulas de matemática, mas que nunca haviam "parado para pensar" sobre o que seria um Problema nem sobre sua função em sala de aula. Em alguns casos os alunos indicaram que entendiam que um Problema seria "uma aplicação de alguma parte da matemática que pode ser aplicada no mundo real" (FTF, TAI-E1, PEF).

Uma discussão importante para a compreensão dos discursos sobre os Problemas, da perspectiva como os licenciandos se apropriaram no decorrer de suas experiências pessoais, ocorreu no contexto do questionamento sobre o que compreendiam por ensinar matemática a partir da resolução de Problemas.

RPG: Significa você apresentar um Problema antes [...] não ensinar a matéria primeiro. Dar o Problema e deixar os alunos pensarem [...] só depois ensinar. LRS: Mas se você não ensinar antes, como o aluno vai resolver o Problema? RPG: Às vezes resolve. Você pode ir dando dicas e, às vezes, algum aluno já sabe algo parecido e resolve [o Problema].

LRS: Mas aí não era um Problema [...] porque ele já sabia resolver. Acho que um Problema é só quando você não sabe resolver.

Professor: Você acha que um Problema só existe quando você não sabe como resolver, [nome]?

LRS: Sim, professor. Acho que sim. Porque se o aluno já sabe resolver não é um Problema, é uma aplicação.

Professor: Então você vê diferença entre Problema e aplicação?

LRS: Sim. Um Problema só é problema se eu não sei fazer. Se já sei é só aplicação do que sei (risos)

Professor: Legal. Alguém discorda? (ninguém responde)

(RPG e LRS, TAI-E1, PEF).

Nessa discussão, verificamos que LRS concebe um Problema como algo que não se sabe resolver. Notamos que sua apropriação se distingue daquela a que, ao que parece, RPG se referia. Na discussão sobre o que compreendiam por ensinar matemática a partir de Problemas, enquanto RPG parece estar com seu foco voltado para a ordem cronológica em que o Problema é apresentado - se antes ou depois da apresentação do 
conteúdo - LRS parece estar preocupado com um aspecto mais conceitual do que seria um Problema. Para ele, uma aplicação de algo que o aluno já sabe não poderia ser classificada como "Problema" e, portanto, não poderia ser considerado ensino "a partir" de Problemas.

A concepção de Problema, na perspectiva histórico-cultural, como já evidenciamos, se aproxima dessa ideia. Se o estudante já domina algum algoritmo ou conhece alguma definição ou propriedade que, aplicada adequadamente, indica uma solução à questão que se apresenta, tal questão apenas contribui como recurso de verificação da capacidade de aplicação de algo já ensinado. Entendemos, ainda, que o Problema se caracteriza pela necessidade que ele suscita, ou seja, mais importante do que saber ou não algum algoritmo, definição ou propriedade que possa ser aplicada para resolver a situação apresentada, é preciso haver necessidade de se resolver.

Também podemos inferir dessa discussão uma característica relevante acerca da compreensão dos licenciandos sobre o papel dos Problemas nas aulas de matemática. O questionamento de LRS - "mas se você não ensinar antes, como o aluno vai resolver o Problema?" - sugere uma apropriação que pressupõe que o professor ensine antes determinado conceito, para posteriormente propor os Problemas. A contradição se verifica na defesa do próprio licenciando de que, quando o aluno já sabe alguma estratégia de resolução, a questão não se configura como um Problema. Essa contradição nos leva a inferir que o licenciando, ainda que conceba uma, a nosso entender, adequada distinção entre "questão de aplicação" e "Problema", ele fica "preso" ao modelo tradicional definição-aplicação-exercícios.

Na discussão sobre como os licenciandos utilizariam um Problema em uma aula hipotética, na qual o objetivo fosse que os alunos compreendessem a noção de Juros Simples, verificamos, mais uma vez, a tendência de os licenciandos reproduzirem modelos de práticas pedagógicas que experimentaram pela observação e imitação de modelos.

RAA: Ah, eu trabalharia... primeiro eu explicaria a matéria - se eles não soubessem, né?

Professor: Não... estamos supondo que eles não sabem... é o primeiro contato deles com o tema...

RAA: Ah... então... eu ensinaria primeiro a matéria dando alguns exemplos... eu acho que exemplo na vida real ajuda muito... então, mostrar algum tipo de Juro... 
sei lá... de banco... alguma coisa bem simples... eu acho que o aluno entende muito melhor... pelo menos eu vejo isso no EJA, onde eu faço o estágio... se você leva a história da matemática pra ele, na vida real, eles entendem muito mais fácil do que se você colocar 'ah, eu tenho uma maçã e vou dividir no meio'... eles não entendem, não é fácil entender... agora, se você leva na vida real, eles entendem muito mais fácil... então, eu explicaria a matéria, depois aplicaria o Problema e depois ia discutir pra ver o que eles acharam, como que eles chegaram na solução, pra ver se entenderam ou se não entenderam... porque aí é o final, nessa conversa... se entendeu ou não, você vai ver se realmente ensinou, ou o que errou ou o que não errou, porque que não chegou no resultado... eu acho a forma mais fácil e correta de trabalhar.

Professor: E quando você fala 'exemplos da história da matemática na vida real' no que você está pensando?

RAA: Não... mostrar pra eles os juros, por exemplo: onde se aplica, onde eles vão utilizar, onde tem esses juros... pra, mais ou menos, eles entenderem pra que que serve... o que é... é a pergunta mortal da matemática: 'pra que que eu vou aprender isso, onde que eu vou ver isso?'... então, se você já levar: 'oh, você vai usar isso aquil'... eu... eu acho que é mais fácil de aprender.

Professor: E esse seu "achar", é da sua experiência como aluno?

RAA: Sim... e de ver a professora dando aula no EJA [durante o estágio supervisionado]. Toda vez que ela usa alguma coisa que, ou eles trabalham ou eles têm contato, eles entendem muito mais fácil do que colocar só os números na lousa.

(RAA, TAI-E1, PEF).

Chamou nossa atenção, de maneira especial, a referência que o licenciando faz do "uso da história da matemática [...] na vida real". Na justificativa a essa referência o licenciando indica que por "história da matemática na vida real" está pensando nas aplicabilidades da matemática no cotidiano, bem como nas necessidades do domínio dessa noção para o exercício da cidadania. Notamos que ele não se remeteu a uma história factual, nem a uma definição formal dos Juros como uma remuneração monetária em função do tempo em que um capital fica indisponível. Entendemos que esse licenciando compreende, de certa forma, o Problema como algo que suscite uma necessidade de apropriação do conceito para uma aplicação direta. A proposta dele, no entanto, indica que ele iniciaria "explicando a matéria", o que descaracterizaria o Problema, na perspectiva que LRS, por exemplo, havia proposto em outro momento.

Como o próprio licenciando explicita, essa opção metodológica decorre da observação das práticas da professora supervisora do estágio e dos momentos em que o estagiário avalia que a professora obteve "sucesso" nas práticas de ensino, ou seja, quando ele entende que o "aluno aprendeu mais facilmente". Essa concepção é, a nosso entender, indício de um sentido em que, na busca por uma solução para o seu problema - adotar um Problema para ensinar a noção de juros simples -, o licenciando recorre aos 
seus modelos de sucesso e, sendo esse modelo fruto da observação e da racionalização das práticas da professora supervisora do estágio, ele tende a repeti-las.

Discutindo essa proposição - de iniciar a abordagem "explicando a matéria primeiro" - outros licenciandos apresentaram alternativas que evidenciaram suas apropriações sobre os discursos a respeito das características dos Problemas para os objetivos do processo de ensino e de aprendizagem, considerando as relações entre Problemas e contextualizações que remetem à aplicabilidade em situações ditas "reais". Ainda tratando de uma hipotética preparação de uma aula para tratar de Juros Simples outra licencianda posiciona-se da seguinte forma:

MCB: Eu falo por experiência, até minha, em algumas matérias... às vezes você chegar e... dar o conteúdo... e depois explica... você vai lá, dá o conteúdo e depois explica... bacana... é o que a gente tem... mas eu acho que você pode abordar de uma outra forma... quando você fala do cotidiano [apontando para RAA, que falou antes sobre a aplicabilidade do conceito em situações reais] eu penso numa coisa mais real ainda, para a maioria das pessoas: compra a prazo. Essa é uma coisa que a maioria das pessoas fazem. Eles vão lá, e eles pensam... ou eles querem celular, principalmente os adolescentes, eles querem celular, eles querem tênis... eles querem alguma coisa... e tem uma diferença... em folhetos... eh... Casas Bahia, eh... eu num lembro agora o nome das outras lojas... mas, enfim... nesses folhetos tem uma diferença do preço à vista e do preço a prazo... e isso, se você começa abordando esse tipo de coisa, sem dar a matéria, depois você explica a matéria... que foi o que você [novamente apontando para RAA]... talvez... talvez você tenha uma resposta positiva... mas acho que depende da turma.

Professor: A sua proposta então é... você pensa que seria mais importante você tratar do conteúdo todo... de juros...

MCB: Não... não... sem dar conteúdo... a situação primeiro.

Professor: Entendi. Depois você vai mostrando que naquela situação, tais conceitos estão envolvidos...

MCB: Exato.

(MCB, TAI-E1, PEF).

A licencianda, como entendemos, tem uma preocupação com o papel desempenhado pelo professor diante da apresentação do Problema, bem como com o perfil dos alunos que participam da aula. Na fala dela fica implícita - "talvez você tenha uma resposta positiva... mas acho que depende da turma" - a percepção de que o Problema, em si, não tem potencial para "ensinar matemática", o processo de ensino deve ser mediado, principalmente pelo professor, e deve ainda considerar as características dos estudantes. Outro licenciando apresentou um entendimento distinto, mas também em relação às características da turma: 
SFM: Acho que abordar alguns conceitos iniciais varia muito de acordo com a turma e com o conteúdo, né? Assim... eu não consigo pensar num Problema, assim agora... assim... de Juros... mas, eu gosto de sempre trazer um Problema do cotidiano... assim, que nem a [nome] [apontando para MCB]... por exemplo, em razões trigonométricas no triângulo retângulo... eu coloco duas rampas e falo 'qual que tá mais inclinada?'... 'como que você faria pra descobrir a inclinação daquela rampa?' e ele [o aluno] sozinho chega na razão, que é a tangente... e aí, acho que trazendo o Problema, ele consegue...

Professor: Você faz a pergunta... coloca o Problema lá, por exemplo, e aí o aluno, na investigação, só pelo Problema, ele chega na resposta [SFM: (interrompendo) isso mesmo...] que você tá esperando?

SFMS: E aí eu formalizo o conteúdo...

Professor: O conceito.

SFMS: Isso.

(SFMS, TAI-E1, PEF).

Vemos que o licenciando atribui ao Problema o potencial de ensinar. A fala "e ele sozinho chega à razão, que é a tangente", pressupõe que o Problema será resolvido sem nenhuma intervenção do professor, apenas pela necessidade de resposta suscitada por um Problema com contexto ligado à realidade. Mais uma vez, entendemos que tal posição do licenciando tem relação direta com suas próprias experiências, de maneira intuitiva - "eu coloco duas rampas e falo 'qual que tá mais inclinada?' e ele [o aluno] sozinho chega na razão, que é a tangente".

Verificamos também algumas discussões acerca de situações que envolviam casos particulares e casos gerais. A compreensão dos licenciandos é a de que o Problema que trata do caso particular é mais "fácil" e que facilita a compreensão da, posterior, generalização. Essa constatação também advém da observação de experiências singulares, de observação - portanto, sensoriais - das práticas de outros professores, que foram avaliadas pelos licenciandos como satisfatórias.

MCB: Foi o [cita o nome de um dos professores do curso de licenciatura em matemática da instituição]... o [repete o nome] em Teoria dos Números [disciplina da matriz]... ele fez uma coisa, assim, que pra mim foi o máximo... ele dava uma explicação de um conteúdo e aí, antes de fazer a demonstração... ele dava um exemplo numérico... daquilo que tinha na demonstração pra fazer... mas ele dava aquele exemplo numérico, antes [colocando ênfase na palavra]... e dava... quando ele ia fazer a demonstração... ela era óbvia [estalando os dedos]... entendeu?... tipo assim, você conseguia, eh, tá um passo à frente do que ele tava escrevendo na lousa... isso foi o máximo... sabe?. Quando, tipo... você vai ensinar alguma coisa, mostrar um pouco antes algumas coisas que não são [pausa por não encontrar o termo adequado]... [outra licencianda: (incentivando) abstratas?]... é... isso... que você consiga mostrar pra pessoa, acho que ajuda muito... eh... [silêncio]... como é que eu vou explicar?... num seria nem a palavra, [mas] deixar [o conteúdo] transparente... mas é como se deixasse um pouco mais claro, nítido o que você tá... 
Professor: [interrompendo] O que você vai fazer depois... o próximo passo? MCB: Isso.

(MCB, TAI-E1, PEF).

A ideia de apresentar um caso particular de um Problema - nesse caso o Problema seria a demonstração de certa propriedade na Teoria dos Números -, segundo a compreensão apresentada, indica a concordância com o argumento de que um caso particular pode subsidiar uma compreensão "mais fácil" da resolução do próprio Problema, realizada posteriormente. A expressão de que "isso foi o máximo", expressada pela licencianda indica que ela selecionou esta prática como adequada, pois teve sucesso em compreender a resolução do Problema - a demonstração da propriedade matemática - em que pese não ter sido ela mesma a realizar tal tarefa.

Um dos participantes do nosso experimento formativo, que já atua como professor, apresentou um depoimento que nos chamou a atenção, pelo fato de, diferentemente dos demais, ter descrito que já havia apresentado o Problema às suas turmas e indiciou os resultados que obteve.

TLL: O que eles [referindo-se aos colegas que falaram antes] falaram, eu também já fiz uma vez... com Juros... é a lei de aplicação na poupança... só que a juros simples... certo? Por exemplo, se você investir cem reais hoje, na poupança... aí eu falo 'a taxa que o banco, tá oferecendo é... tanto'... aí eu mostrava os rendimentos e mostrava como se fosse uma tabela... organizava os dados em tabela... e no final eles ia[m] começar a pensar 'e daqui tanto tempo?' 'como será que vai... se for seguir essa linha de pensamento?'... ao final a gente ia conseguir até generalizar a fórmula, que é um conteúdo formal que nós temos que passar pra eles, então imagino que a pessoa entenda melhor dessa maneira, entendeu? (TLL, TAI-E1, PEF).

A despeito de ter sido ele próprio, na condição de professor, que, ao que parece, solucionou o Problema, verificamos que foi selecionado um Problema com potencial de colocar o aluno diante da necessidade de pensar sobre a remuneração sobre um capital em função do tempo que ele fica indisponível. Ainda que a abordagem pudesse ter sido distinta para que os estudantes realizassem o movimento de solução, e não apenas acompanhassem o professor resolvendo, havia elementos para a formalização lógica do conceito de Juros, representada pela "fórmula" que relaciona as variáveis envolvidas nos Problemas. A consideração, "imagino que a pessoa entenda melhor dessa maneira", indicia que o licenciando não tenha fundamentação para sustentar sua compreensão do papel dos Problemas em sua prática, e que esta compreensão também seria fruto de 
suas observações e das próprias práticas experimentadas, em função dos resultados que obteve e que ele avaliou como bem-sucedidos.

Entendemos que as apropriações de discursos acerca do uso de Problemas e aspectos ligados à sua resolução, apesar da constante presença desse tema no âmbito acadêmico e no contexto da Educação matemática, aparecem nas considerações dos licenciandos de maneira superficial. Eles indicavam reconhecer que os Problemas seriam importantes, mas não eram capazes de sustentar as maneiras pelas quais essa importância se materializaria em sala de aula.

A abordagem do tema (Problemas) não causou estranheza nos mesmos, indicando que eles consideram que abordar Problemas em suas práticas pedagógicas é uma necessidade, todavia, não passaram por uma formação específica para tanto, de modo que suas compreensões sobre o papel do Problema remeteriam às experiências pessoais, algumas dessas, inclusive, exclusivamente ocorridas no contexto de suas vivências como estudantes. De modo geral, os licenciandos parecem tender a reproduzir, por considerarem "adequadas", práticas observadas por eles e que eles classificariam como situações em que se obteve "sucesso". Importante destacar, também, que esse "sucesso" quase sempre remetia ao fato de eles próprios terem logrado aprovação ou boas notas nas "provas" ou pelo desempenho dos estudantes em avaliações específicas.

Não causou estranheza nos licenciandos o fato de, apesar de eles avaliarem que conheciam o conceito de Juro, não terem sido capazes de defini-lo sem recorrer a exemplos particulares nem propor, a princípio, um Problema envolvendo tal conceito.

Para suas regências de estágio, os licenciandos voltaram a apresentar o que reconhecemos como indícios de seus sentidos pessoais iniciais a respeito do conceito de Problema e de sua importância na sala de aula de matemática, incluindo, no entanto, aspectos apropriados no decorrer dos estudos formativos que realizamos naquele primeiro semestre, no âmbito das disciplinas do curso.

Apenas um dos licenciandos referenciou a teoria Histórico-cultural como fundamentação para sua atividade de regência. O licenciando TLL indicou um objetivo voltado a planejar e executar sua regência "tomando por base a Teoria das Situações Didáticas e também a Teoria Histórico Cultural" (TLL, RES, PEF, p. 6). O licenciando evidenciou conhecer a Teoria das Situações Didáticas - TSD, referenciando Brousseau 
(1986). Quando questionado sobre tal contato com essa teoria ele esclareceu que a referida teoria estaria fundamentando a elaboração de seu Trabalho de Conclusão de Curso e the teria sido apresentada por sua orientadora, professora do IFSP no curso de licenciatura em matemática, no contexto da orientação para elaboração do trabalho.

Apesar de não termos estabelecido paralelos comparativos entre a THC e outras teorias durante o curso, o licenciando indicou que "a Teoria das Situações Didáticas tem relação com a Teoria Histórico Cultural, que reconhece que o discente aprende efetivamente quando está perante um Problema que faz sentido" (TLL, RES, PEF, p. 7). Ainda que não concordemos inteiramente com esta afirmação, faz-se necessário o registro do exercício de comparação realizado pelo licenciando. Certamente, a capacidade de comparar pressupõe alguma apropriação dos aspectos a serem comparados, o que indicia um enriquecimento do corpus teórico que o licenciando pôde construir.

Especificamente, no entanto, buscamos superar essa ideia de que "o discente aprende efetivamente quando está perante um Problema que faz sentido". Em primeiro lugar, porque o conceito de sentido é um conceito caro em nossa perspectiva, remetendo a um caráter individual. Logo, o sentido de um aluno diante de um Problema não é, necessariamente, o mesmo sentido de outro aluno diante do mesmo Problema, de modo que não há como propor Problemas "que fazem sentido" para todos os alunos, de acordo com os pressupostos que defendemos. Os sentidos remetem ao movimento de apropriação da produção humana historicamente constituída, e não a uma "coisa" inerente ao Problema.

Entendemos que o Problema pode estar impregnado do conceito que se objetiva ensinar ou aprender, mas não deixa de ser simplesmente um Problema. Dessa forma, o Problema, por si só, não ensina, nem mesmo quando um aluno consegue resolver esse Problema. Ou seja, ainda que o discente esteja diante de um Problema "que faz sentido", assim entendido aquele que remete a situações que ele reconhece e interpreta adequadamente, sem a tomada de consciência a respeito da atividade que se realiza no processo, a aprendizagem fica prejudicada.

O Problema adotado para a regência pelo licenciando TLL foi denominado por ele como "A função do copo". O nome foi um trocadilho com o termo "função" que remete 
tanto ao conceito matemático, que pressupõe a análise de grandezas que se relacionam, quanto à ideia de "serventia" do copo. Sendo o copo um objeto que serve para armazenar substâncias, geralmente líquidas, a situação propõe apresentar aos alunos um copo com certa quantidade de água e algumas bolinhas de gude médias e grandes. A ideia é ir acrescentando bolinhas de gude - primeiro as médias e depois as grandes - e controlando o nível da água a cada acréscimo. O Problema, que o licenciando classifica como "questão desencadeadora" (TLL, RES, PEF, p. 8), consiste em indicar "quantas bolinhas de gude [de cada tamanho] seriam necessárias para fazer o copo transbordar?".

Esse Problema, certamente, coloca o aluno diante da necessidade de apropriação da essência do conceito de função, qual seja, a comparação entre grandezas variáveis, no caso, a quantidade de bolinhas e o nível da água no copo. Obviamente, para um certo número $x$ de bolinhas a altura y da água ultrapassará o limite de altura do copo $\mathrm{e}$ transbordará.

O licenciando narra que apresentou a situação e o Problema e deixou os alunos, organizados em grupos com 5 alunos cada, refletirem a respeito. Ele registra que todos os grupos faziam anotações do que acontecia com o nível da água à medida em que as bolinhas eram colocadas, "mas não sabiam o que fazer com aqueles dados" (TLL, RES, PEF, p. 9) e que "apenas" (segundo o aluno) dois grupos conseguiram resolver o Problema, "mas usando regra de três" (TLL, RES, PEF, p. 9). O próprio licenciando, a julgar pelo registro, não reconhecia as aproximações entre a técnica de resolução conhecida como "regra de três" e a definição de função afim. Ele indica que, ao recorrer à "regra de três" os alunos não teriam usado o conceito de função afim que era seu objetivo. Ele registra, ainda, que os demais grupos tentavam "usar equações para se chegar a algum resultado, no entanto sem sucesso" (TLL, RES, PEF, p. 9). Por fim o licenciando, referindo-se a si mesmo com o termo "mediador", indica que, após cerca de 30 minutos de "tentativas" dos alunos, tratou de "introduzir a ideia de pontos no plano cartesiano, e relacionou os eixos $x$ e y com o número de bolinhas e o nível da água respectivamente" (TLL, RES, PEF, p. 9).

Verifica-se que o licenciando apresenta o Problema aos alunos e os convida a refletir sobre o mesmo. A despeito de referir-se a si próprio utilizando o termo "mediador", o licenciando atua em dois momentos distintos: um como observador dos alunos em ação 
e outro como expositor de uma solução para o Problema. Não pudemos identificar um processo de mediação.

Entendemos razoável supor que a ideia, apropriada pelo licenciando da TSD, de que todas as situações têm um Problema que lhe corresponde e que tal Problema possui, em si, a partir da resolução, potencial para que o aluno aprenda, possa ter sido preponderante para as opções metodológicas do estudante. Ao optar por apresentar sua solução, entendemos que o licenciando deixou de explorar o processo de resolução dos grupos que chegaram a uma solução utilizando "regra de três", tanto em relação à socialização dessa solução, quanto em relação à possível exploração de relações entre o que chamamos "regra de três", a ideia de razão e proporção e o próprio conceito de função, bem como os "erros" dos demais grupos que tentavam "resolver por equações", já que há estreita relação entre os conceitos de equação e de função, sobretudo quando ambas remetem ao polinômio de primeiro grau, como é o caso.

Outra licencianda, JZM, propôs a realização do que ela classificou como "gincana", com o intuito de, segundo seu próprio entendimento, "tornar lúdica a atividade de regência" (JZM, RES, PEF, s/p). Em sua proposta, com o objetivo de consolidar as operações aritméticas envolvendo números racionais, expressos na forma decimal, a licencianda registrou que a professora supervisora prefere que as atividades dos estagiários sejam realizadas apenas "depois que ela já trabalhou os conteúdos", a título de reforço, o que dificultou sua proposta de utilização de Problemas. Essa licencianda possuía uma experiência como bolsista junto ao PIBID, e seu relato apresenta referências à sua atuação naquele programa, como sendo fundamental para sua formação como professora (JZM, RES, PEF, s/p).

A situação organizada propõe a apresentação de diversos desafios, que ela classifica como "Problemas", que poderiam ser resolvidos mediante a aplicação dos algoritmos já ensinados previamente pela professora supervisora. Os desafios foram colocados no interior de balões e presos com fita adesiva à lousa. Os alunos se organizaram em dois grandes grupos que, alternadamente, mandavam um representante à lousa para que, por sua vez, estourasse um balão. Ele, então, voltava para seu grupo para resolver o Problema. Se conseguissem resolver apresentavam a solução na lousa para avaliação da professora, que homologava o acerto (ou indicava o erro). 
A despeito de as questões sorteadas pelos alunos remeterem a um algoritmo já ensinado previamente, verificamos uma atenção especial da licencianda à busca pela socialização da solução encontrada o que, de acordo com ela, possibilitou reflexões a partir das respostas incorretas dos alunos. Chamou nossa atenção, também, o registro de uma situação em que, ainda que a resposta apresentada pelos alunos estivesse matematicamente correta, a professora não homologou a resposta (considerou "errada") em razão de os alunos não terem utilizado o algoritmo que ela havia ensinado, ou seja, o método alternativo de solução aplicado pelos alunos, ainda que tenha conduzido à resposta esperada para o Problema, foi considerado "errado" pela professora. Essa situação mereceu destaque específico da licencianda, que ponderou que não era objetivo da "atividade", em suas palavras, averiguar se os alunos sabiam reproduzir a forma de fazer que a professora ensinou, mas sim se conseguiam interpretar e resolver o Problema sorteado.

O Problema em questão, de acordo com a licencianda, consistia em resolver adequadamente à questão "uma caixa de leite com 12 litros custa $R \$ 18,60$. Qual o preço de 1 litro de leite?" (JZM, RES, PEF, s/p). E a solução apresentada pelos alunos foi a da imagem abaixo, fotografada pela estagiária:

Figura 8: Imagem da solução dos alunos durante a regência da licencianda

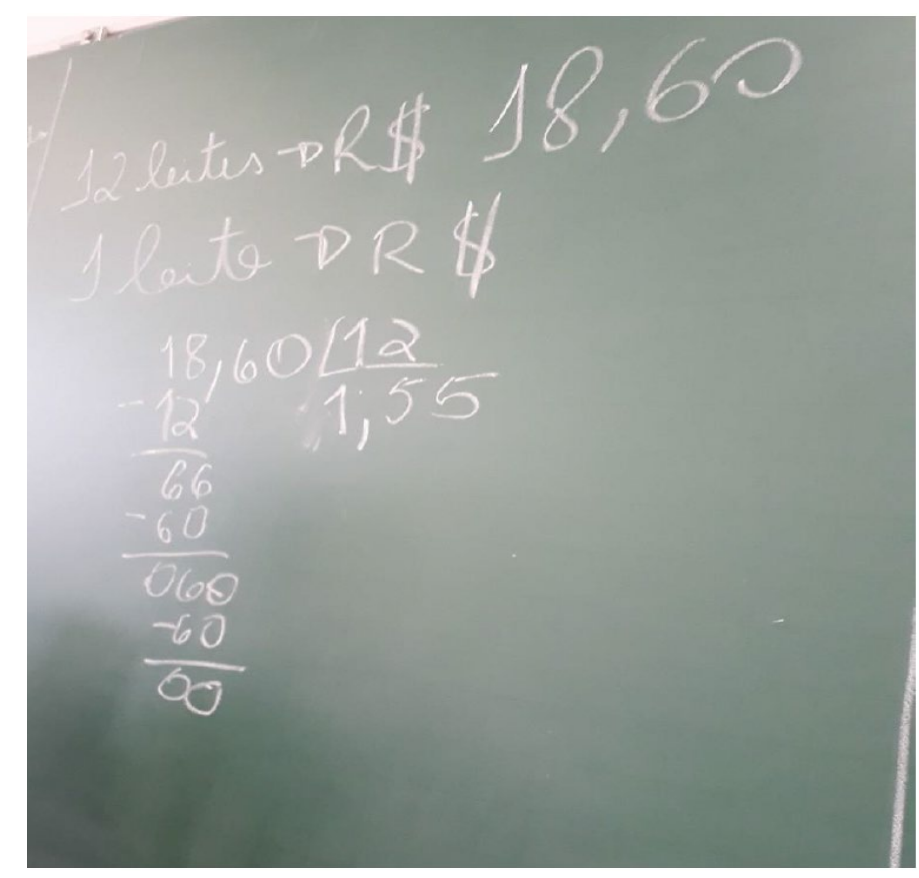

Fonte: Foto da licencianda JZM, e digitalizada do relatório de estágio. 
A professora não aceitou a utilização do algoritmo da divisão entre decimais, da forma como foi realizada pelos alunos - um dos alunos do grupo havia aprendido essa forma de cálculo anteriormente e utilizou. O cálculo desenvolvido pela criança poderia ser compreendido, de acordo com a licencianda, da seguinte forma:

Dezoito reais dividido por doze, dá um real e sobram seis. Esses seis reais equivalem a 60 moedas de dez centavos que adicionadas às seis moedas de dez centavos que já tinha no valor inicial, ficam sessenta e seis moedas de dez centavos. Estas, por sua vez, divididas por doze, resultam em cinco moedas de dez centavos e sobram outras seis. Trocando essas seis moedas de dez centavos por moedas de um centavo, podemos dividir as sessenta moedas de um centavo por doze e encontrar no quociente, cinco centavos. Logo, a solução para o Problema seria, um real, cinco moedas de dez centavos e cinco moedas de um centavo, ou seja, um real e cinquenta e cinco centavos. (JZM, RES, PEF, $\mathrm{s} / \mathrm{p}$.).

A licencianda não explicitou, no relatório, se, durante a utilização do algoritmo, foi o aluno que socializou a solução, nestes termos, ou se essa foi a interpretação que ela própria deu à solução do aluno, mas, de acordo com a estagiária, a professora consideraria como correta a solução somente se o aluno "igualasse as casas decimais para cancelar a vírgula" (JZM, RES, PEF, s/p.) obtendo a divisão equivalente de 1.860 por 1200. A partir daí o aluno deveria seguir o algoritmo da divisão de um inteiro por outro. Não vamos tecer considerações a respeito da opção da professora supervisora, já que não conhecemos seus objetivos e a mesma não é uma das participantes de nossa pesquisa, mas, cumpre destacar que sua decisão de considerar "errada" a solução dos alunos por não utilizar o algoritmo que ela apresentou chamou a atenção da licencianda e foi destacado por esta em seu relatório de estágio, indicando que JZM compreendia o Problema como reflexo da apropriação do conceito e não apenas como recurso de aplicação de um algoritmo específico.

Já RPG realizou, além das demais atividades de observação e participação, o planejamento e a organização de uma proposta de regência de para o estágio supervisionado. Ela registra o objetivo de "introduzir o conceito de função afim, seu gráfico e suas particularidades" (RPG, RES, PEF, s/p) e apresenta o Problema proposto:

Ao realizar uma pesquisa na internet para a compra de um celular, uma pessoa encontrou apenas duas lojas que tinham o produto desejado em estoque. Na loja A, o aparelho celular custa $R \$ 1.700,00$ e o frete é grátis, já na loja $B$, o aparelho 
celular custa $R \$ 1.550,00$ e o frete cobrado é de $R \$ 3,00$ por quilômetro rodado. Nessas condições, responda:

a) Se uma pessoa mora a uma distância de $30 \mathrm{~km}$ do depósito da loja B, qual loja é a melhor opção para essa pessoa?

b) A partir de qual distância a compra do aparelho celular na loja B é mais vantajosa $[\mathrm{sic}]^{23}$ ?

c) Descreva o preço a ser pago pelo celular, considerando o frete por meio de uma expressão matemática.

(RPG, RES, PEF, s/p).

A aluna indica, contudo, que questões administrativas da escola concedente, onde ela realizava o estágio supervisionado, impossibilitaram a efetivação da regência utilizando essa proposta - as atividades de regência que foram realizadas em outros momentos, não abordaram a utilização de Problemas, como nos interessava em naquele momento. Ainda assim, podemos verificar que a aluna elaborou um Problema baseandose em um modelo tradicionalmente utilizado no contexto do ensino de funções.

De acordo com Panossian, et al, (2014, p. 61) nesse tipo de situação "os dois primeiros itens podem ser resolvidos aritmeticamente. No próprio enunciado está a relação estabelecida e cabe aos estudantes reconhecê-la, identificando os valores numéricos [...] para o item c o desafio é o de escrever ou representar simbolicamente a relação que já está estabelecida". Essa constatação traz à tona, novamente, o registro dos licenciandos, por ocasião da sondagem a respeito de suas apropriações sobre o papel dos Problemas nas aulas de matemática, em que eles entendiam que apresentar um caso particular, resolvido aritmeticamente, "facilitava" a compreensão posterior da generalização.

Ainda conforme Panossian, et al, (2014), nesses casos

[...] os alunos não precisam se preocupar em encontrar grandezas que variam, verificar como essa variação acontece, identificar as relações entre as grandezas. Os nexos conceituais da variável já estão apresentados, o que cabe ao estudante é apresentar o conceito em sua forma de representar. Entretanto, nada garante que, ao representar simbolicamente a relação usando as letras indicadas, o aluno realmente tenha compreendido como essa relação entre grandezas se dá, ou

${ }^{23}$ Estamos supondo que a licencianda, ao elaborar o Problema, pode ter se equivocado ao indicar no item b "a partir de qual distância a compra do aparelho celular na loja B é mais vantajosa?". Isso porque a compra nessa loja B é mais vantajosa nas distâncias que variam de 0 a $50 \mathrm{~km}$, e a partir daí a loja A é que passa a ser mais vantajosa. O uso do termo "a partir de qual distância" nos leva a crer que a estudante pretendia realizar essa verificação, mas em relação à loja $A$, e não à $B$. 
qual é o campo de variação dessas grandezas (PANOSSIAN, et al, 2014, p. 61 e $62)$.

Teoricamente, resolver a questão proposta no item c dá ao estudante a ferramenta ideal para resolver $\mathrm{a}$ e b ou qualquer outro caso particular, já que o item c é a generalização dos casos particulares a e b. Mas se essa questão, apresentada frequentemente em livros com algumas variações de contexto, pode contribuir para a solução dos itens anteriores, por que ela é apresentada como item c e não no a? A razão, ao que parece, é justamente uma compreensão sobre o papel dos Problemas, de que o percurso do caso particular para o geral seria "facilitador" do processo de aprendizagem.

Outra licencianda, DFS, a fim de introduzir a noção de Polinômios, propôs aos alunos a resolução do seguinte Problema:

Um artesão faz caixas decorativas de madeira. Os mais pedidos trabalhos deste artesão são as caixas cúbicas decoradas com fitas. As fitas são colocadas nas arestas de toda a caixa e a tampa possui dobradiças para levantá-la e abaixá-la. O preço de uma caixa dessas depende de seu tamanho. Uma cliente pediu que fosse feita uma caixa com lado medindo $20 \mathrm{~cm}$. Para calcular o preço final da caixa, que é o custo de fabricação mais o lucro, o artesão deve considerar que: Cada metro da fita custa 2 reais;

Para cada metro de área em madeira o artesão paga $R \$ 30,00$;

Se precisar enviar a caixa pelo correio terá uma taxa pelo volume de $\mathrm{R} \$ 0,50$ por cada $1000 \mathrm{~cm}^{3}$;

Para obter lucro, o artesão cobra uma taxa fixa de $R \$ 12,00$ por cada caixa feita. Sendo assim, quanto custou para o artesão fazer a caixa? E qual será o preço final da caixa pedida pela cliente sendo que será enviada pelo correio? Como o artesão pode calcular o preço final de uma única caixa cúbica sabendo apenas um lado?

(DFS, RES, PEF, p. 28 e 29)

Mais uma vez, o Problema compreende um movimento que parte do caso particular para o geral, já que a resposta para "como o artesão pode calcular o preço final de uma única caixa cúbica sabendo apenas um lado?" é a generalização que atende aos itens anteriores. Cabe destacar o esforço da licencianda para colocar o aluno diante da necessidade de representação de variáveis distintas, o que pode suscitar muitas oportunidades pedagógicas de exploração e análise para consolidação do conceito de polinômios, indo de encontro à formalização de regras para a adição e subtração de termos semelhantes e as aplicações de propriedades das potências, que são mais tradicionalmente apresentadas quando se propõe a abordagem de tal conceito matemático. 
A aluna indica que, durante a regência, dividiu a turma em duplas ou trios, que trabalharam coletivamente, entre si, mas não indicou se houve socialização dos resultados de cada dupla/trio para toda a turma. Ela registra também que

Não demorou 5 minutos e algumas duplas já solicitaram a minha ajuda,
especialmente para compreender o que foi pedido no problema proposto. De
carteira em carteira, solicitei aos alunos que lessem com calma a situação
apresentada e fizesse parte a parte para resolver. Aos poucos os alunos
compreendiam o problema, mas surgiram dúvidas pertinentes quanto ao
processo de resolução. Eu deixei claro que eles poderiam resolver como
achassem melhor: por expressões algébricas, por desenho, por dedução,
construindo quadros, enfim, porém eles não conseguiam entrar em um acordo
sobre como resolver. (DFS, RES, PEF, p. 20).

DFS atribui parte das dificuldades dos alunos para resolver o Problema ao fato de que "os exercícios que o professor [supervisor] propõe [durante aulas] a eles têm caráter imediatista e apenas focam na repetição de processos de cálculos. Isso interferiu na resolução da situação proposta no dia da regência" (DFS, RES, PEF, p. 21). Da mesma forma que na regência da licencianda JZM, entendemos que a atuação do professor supervisor influenciou significativamente o desenvolvimento da regência, ainda que, nesse caso, o professor não tenha interferido diretamente na proposta da estagiária, como naquele caso.

A licencianda apresenta suas intervenções junto aos grupos, indicando que escutava as dificuldades de cada um e buscava "dar dicas" que contribuíssem para a solução. A licencianda, ao que parece, apresentou sugestões a respeito do processo de solução, inclusive que se "fizesse parte a parte para resolver", o que lembra uma das estratégias apresentadas por Pólya para a solução de Problemas, que é a de reduzir um Problema em partes "menores". Ao final da regência, a licencianda tinha intenção de apresentar a solução na lousa, mas "os alunos pediram para que eu [licencianda] apenas apontasse os conceitos que deveriam ser aplicados na resolução, pois eles mesmos queriam resolver o problema em casa" (DFS, RES, PEF, p. 23, grifo nosso). Esse registro indica que os alunos foram motivados a resolver o Problema proposto, ou seja, podemos inferir que os alunos sentiram necessidade de resolver o Problema e que não alcançar a satisfação dessa necessidade gerou neles um desconforto, de modo que solicitaram, 
além da extensão do prazo para apresentação da solução para o Problema, o auxílio que julgaram adequado para satisfazer essa necessidade.

No entanto, o auxílio remeteu à indicação de qual seria o aspecto do conceito a ser aplicado. DFS parece não se atentar para o fato de que esta indicação a respeito do conceito a ser aplicado é, na prática, apresentar uma importante pista para resolver o Problema, o que pode prejudicar o movimento próprio do aluno. Todavia, entendemos como muito importante essa consideração de DFS, pois indicia que os alunos estavam, de fato, em um movimento de aprendizagem distinto daquele a que vinham sendo submetidos nas aulas de matemática coordenadas pelo professor supervisor.

O licenciando ISC, por sua vez, apresentou um relato de atividade de regência que propunha a utilização de Problemas com aspectos da história do conceito explicitamente explorados. O aluno também não faz referência a aspectos teóricos que, eventualmente, teria utilizado como fundamentação para sua proposta, mas denota em alguns momentos, pelos termos que utiliza, que se apropriou de uma caracterização de Problema próxima daquela que discutimos nas aulas de Prática de Ensino. É o caso, por exemplo, de quando ele vai apresentar os objetivos da regência referindo-se a uma "proposta desencadeadora de aprendizagem". (ISC, RES, PEF, p. 5).

A proposta tratou do conceito de frações. O licenciando recorre à história da origem das frações, nos processos de demarcação de terras no antigo Egito, contando para os alunos a história (factual), incluindo a apresentação da unidade de medida "cúbito", que seria a medida do cotovelo à ponta do dedo do faraó. Ele então propõe aos alunos que façam uma demarcação de áreas na sala.

Dividimos a sala em grupos de 5 alunos [4 grupos], escolhemos a medida padrão "cúbito" [que foi] a medida do pé de um aluno, em seguida marcamos na sala com fita crepe 4 áreas que representavam as terras destinadas a moradia, plantio, criação de animais e mercado de trocas no Egito, e cada grupo ficou responsável para medir uma área utilizando a medida padrão "cúbito".

(ISC, RES, PEF, p. 6).

O licenciando relata que as medidas inteiras eram facilmente encontradas pelos alunos, mas as medidas menores, do que o padrão, causaram um desconforto, "exigindo o auxílio do estagiário". Ele realizou, na verdade, uma intervenção mostrando aos alunos 
"como era o procedimento" (ISC, RES, PEF, p. 6), dobrando as unidades ao meio ${ }^{24}$, até que tivessem um "submúltiplo" que possibilitasse medir o que faltava. Os resultados das medições são apresentados, no relatório, por uma tabela e, depois, os valores encontrados para as medidas de um dos lados das áreas demarcadas (todas retangulares) foram posicionados em uma reta numérica. $\mathrm{O}$ objetivo de posicionar os valores numéricos na reta foi ir apresentando as partes no todo para encontrar o denominador comum.

Figura 9: Imagem das medições dos alunos durante a regência do licenciando

\begin{tabular}{|l|l|l|}
\hline \multicolumn{1}{|c|}{ Áreas } & \multicolumn{1}{|c|}{ Lado A } & \multicolumn{1}{c|}{ Lado B } \\
\hline Moradia & $4 \frac{1}{8}$ & $6 \frac{1}{4}$ \\
\hline Plantio & $3 \frac{1}{2} \frac{1}{4} \frac{1}{8} \frac{1}{16}$ & $6 \frac{1}{8} \frac{1}{16}$ \\
\hline Criação de Animais & $4 \frac{1}{2}$ & $6 \frac{1}{4} \frac{1}{8}$ \\
\hline Mercado de trocas & $4 \frac{1}{2} \frac{1}{4}$ & $6 \frac{1}{2}$ \\
\hline
\end{tabular}

Tabela com valores coletado nas medições de terras

Fonte: Tabela do licenciando ISC, e digitalizada do relatório de estágio.

Figura 10: Imagem da reta numérica com as representações do Lado $\mathrm{A}$ da área de Plantio

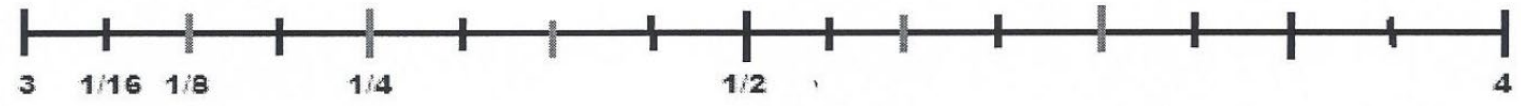

Fonte: Elaborada pelo licenciando ISC, e digitalizada do relatório de estágio.

Notamos que ele colocou na reta numérica todas as subdivisões obtidas na medição do lado A da área destinada ao plantio e apresentou a compreensão de que a divisão equivalente a 1/16 (um-dezesseis avos) "cabe dentro" de todas as outras subdivisões, por isso pode ser chamada de "denominador comum". Desse modo ele pode tratar da noção de fração equivalente ao indicar que a medida de 1/16 "cabe" duas vezes na medida de 1/8 (um oitavo), logo 1/8 é o mesmo que 2/16 (dois dezesseis avos), e assim sucessivamente. Por fim os alunos verificaram que a medida das partes menores

\footnotetext{
${ }^{24}$ Apesar de o licenciando não ter explicitado, podemos supor que ele "transportou" a medida do pé do aluno que serviu como padrão para a determinar o "cúbito" para um objeto manipulável, como um barbante ou fita adesiva.
} 
que o todo (soma das frações) só pode ser obtida se os "pedaços" forem do mesmo tamanho (denominador comum), para obter a resposta de que a medida do lado é de 3 inteiros e 15/16 (quinze dezesseis avos). Colocando 15/16 avos na reta, os alunos verificam que, de fato, essa fração coincide exatamente com a medida que eles haviam tomado.

Figura 11: Imagem da reta numérica com a solução do Problema

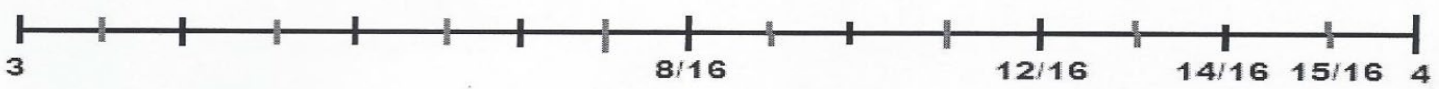

Fonte: Elaborada pelo licenciando ISC, e digitalizada do relatório de estágio.

O licenciando ainda toma a precaução de registrar que realizou uma avaliação diagnóstica, a fim de auferir conhecimentos prévios dos alunos, considerando que eles têm contato com o conceito de frações durante os anos iniciais do ensino fundamental. Nesse registro ele indica que a maioria dos alunos refere alguma recordação do estudo de frações, não supreendentemente, remetendo-se às divisões de objetos do cotidiano como pizzas ou chocolates. Também houve a preocupação de avaliar as percepções dos alunos sobre a regência, apresentando no relatório uma imagem de uma das considerações dos alunos que participaram da atividade.

Achei criativo, diferente, outra forma de aprender fração, porém mais desgastante, já que tínhamos que tirar tudo do lugar, para fazer o desenho no chão. Assim achei que passou o tempo mais rápido e sem ficarmos muito tempo parados na cadeira. (Aluno do licenciando ISC, RES, PEF, p. 7)

O licenciando MGO relatou que utilizou em sua regência, ao final do semestre, a mesma situação que apresentamos, no encontro 7, como uma das nossas SDA, que denominamos de "Jogo de Adivinhação". MGO também utilizou termos que remetem aos estudos que realizamos durante o experimento formativo. De acordo com o licenciando ele pretendeu realizar com os alunos uma "atividade desencadeadora de aprendizagem" (MGO, RES, PEF, p. 3). Na conclusão do relato o licenciando afirma que

[...] resultado foi muito positivo, com relatos positivos dos estudantes em geral e também do professor. Foi uma prática fora da tradicional diária, onde o professor passa conteúdo na lousa explica e passa exercícios, sendo que nesta atividade utilizamos a lousa em apenas alguns minutos, "brincando com as caixinhas" na maior parte do tempo. Muitos queriam continuar as atividades reclamando de não 
conseguirem terminar todos os desafios, mostrando interesse e disposição (MGO, RES, PEF, p. 4).

Especificamente, o licenciando indica que realizou a regência em uma turma do primeiro ano do Ensino Médio da Educação de Jovens e Adultos e justificou a adaptação referente ao público alvo relacionando o estudo de equações com o estudo de funções polinomiais do primeiro grau, de acordo com o cronograma de trabalho do professor supervisor de estágio. Ele indica que "o objetivo desta atividade foi de os estudantes apropriarem o conceito de equação polinomial do $1^{\circ}$ grau através de um material concreto, lúdico e instigante, motivando os estudantes a aprenderem brincando" (MGO, RES, p. 3).

Por fim, a licencianda PNL realizou uma regência em que manifestou indícios de uma compreensão do jogo como Problema. Ela indicou a realização de uma situação desenvolvida a partir do "Jogo do Nim" para o desenvolvimento da compreensão da representação binária de numeração. Ela apresenta o jogo e seu objetivo da seguinte forma:

\begin{abstract}
O jogo do NIM é um jogo de origem oriental que consiste em apresentar, a dois participantes, três fileiras contendo 1, 3 e 5 peças, respectivamente (as peças podem ser palitos, tampinhas, grãos, etc.). As regras estabelecem que os participantes joguem alternadamente, retirando peças de uma, e somente uma, das fileiras em cada jogada. É necessário retirar, pelo menos, uma peça e é permitido retirar até todas as peças de uma mesma fileira a cada jogada. Não é permitido, na mesma jogada, retirar peças de fileiras distintas. Perde o jogo o participante que retirar a última peça. Há variações do jogo que alteram o número de peças em cada fileira ou a quantidade de fileiras. Incentivados a encontrar uma estratégia vencedora, acreditamos que a compreensão da essência do conceito de notação binária impregnado na estratégia vencedora possibilita o reconhecimento de que a estratégia baseada na adição binária é uma das possibilidades de apropriar-se do conceito matemático envolvido. (PNL, RES, PEF, p. 2, grifo nosso).
\end{abstract}

Chamou-nos a atenção a indicação da licencianda de uma apropriação da importância de que as situações propostas aos alunos estivessem impregnadas da essência conceitual para que pudesse ser desenvolvente da aprendizagem. Ela faz uma apresentação da maneira como a representação binária dos números, geralmente, é tratada na educação básica, afirmando que remetem às aplicações atuais em áreas como a tecnologia da informação, na programação de computadores. Ela indica ainda que não considera essa estratégia adequada, já que muitos dos alunos da escola onde realizou o estágio supervisionado não têm acesso regular a computadores, de modo que a 
compreensão das relações entre o sistema binário e os modos de funcionamento das máquinas informatizadas não seria possível.

Para a licencianda "mesmo para o professor, a ideia de que a notação binária tem estreita relação com as funcionalidades informáticas pode ser fruto de conhecimentos superficiais" (PNL, RES, PEF, p. 1). Dessa forma, entendemos que a estudante compreende que a mera possibilidade de aplicação em situações cotidianas não é suficiente para promover estratégias de ensino consideradas adequadas. Por essa razão ela propõe o que caracteriza como um Problema, que consiste em encontrar uma estratégia vencedora para o jogo do $\mathrm{Nim}$. Ela apresenta a estratégia vencedora do jogo, mas não deixa claro se os alunos participantes da regência puderam encontrar tal estratégia ou se a mesma foi apresentada por ela mesma. De qualquer modo, a proposição do jogo entendido como um Problema que colocasse o aluno diante da necessidade de apropriação conceitual para encontrar a estratégia vencedora, justificou o convite também a essa licencianda para a segunda etapa do experimento formativo.

A licencianda PNL afirmava: "Não me vejo como professora! Sei lá... não é pra mim. Eu gosto de matemática e até gosto de ajudar algumas pessoas que não entendem [a matéria]... mas não gosto do clima de sala de aula. Não tenho paciência, sabe? Não nasci pra isso" (PNL, TAI-E1, PEF). A opção pelo uso do termo "não nasci pra isso" nos remeteu a um entendimento de uma suposta necessidade de aptidão natural, dádiva ou dom divino para o exercício da docência. Questionada sobre sua atuação profissional, a licencianda informou trabalhar em uma instituição financeira em que podia aplicar muitos dos conhecimentos que havia adquirido durante o curso.

PNL: Trabalho no [nome da instituição financeira].

Professor: E você gosta de trabalhar lá?

PNL: Sim. Muito. Eu aplico no dia-a-dia muitas coisas que aprendi aqui na faculdade. É muito legal.

Professor: E você tem alguma experiência em sala de aula para já ter decidido assim que não quer ser professora?

PNL: Não... como professora mesmo, não. Só no estágio... mas já foi o suficiente... eu tiro por quando vou ensinar alguma coisa pro meu marido... eu não tenho paciência... ele já até sabe... nem me pede... sei que não é pra mim. (PNL, TAl-E1, PEF)

A licencianda, apesar de indicar que já teve experiências satisfatórias ao ensinar colegas de curso com dificuldades na compreensão do conteúdo, potencializa a experiência insatisfatória que tinha no ambiente familiar ao se dispor a ensinar de alguma 
maneira ao marido. Entendemos que o motivo que levou a licencianda à universidade e ao curso vinha, até então, propiciando um movimento formativo que contribuía para a satisfação de sua necessidade: aprender matemática.

A mesma estudante, em outro momento, também afirma: "Não quero continuar isso [o modelo educacional] que está aí, professor. Os alunos não respeitam a professora. Não querem 'nada com nada' (sic). [...] eu gosto de ajudar quem quer aprender" (PNL, TAI-E1, PEF). Ao que tudo indica, a desmotivação de alunos que a licencianda presenciava em seu estágio supervisionado, contribuía para reforçar sua própria desmotivação para se tornar professora. Mais uma vez ela recorria a explicações naturalistas, concluindo que os alunos simplesmente não queriam aprender por sua própria natureza de não gostar de estudar, sem considerar, contudo, aspectos relacionados à organização da prática docente que não eram capazes de motivar a realização das atividades daqueles alunos.

Já o movimento formativo do licenciando MGO manifestou desde sempre uma motivação que pressupunha um movimento formativo voltado à satisfação da necessidade de aprender a ser professor de matemática. Nesse contexto, aliado à atuação do licenciando como professor-estagiário em um programa de educação de jovens e adultos, colocaram em evidência as contradições percebidas pelo estudante entre o processo formativo que recebeu, intensamente voltado à aprendizagem de conteúdo matemático, e aquilo que seria importante no processo formativo do professor de matemática, especialmente a aprendizagem de modos de organização da prática docente para a atuação com os diversos públicos-alvo da educação.

MGO: Eu adoro matemática, professor. Amo mesmo! Mas eu não ensino isso [que aprendo] aqui para os meus alunos lá do EJA! É fora da realidade... eu não vi, durante o curso, nada que fosse específico para eles [alunos da EJA]... só para alunos na idade "certa"... parece que é a mesma coisa [ensinar para ambos os públicos], mas não é.

Professor: $\mathrm{E}$ no que você entende que é diferente?

MGO: É diferente, professor... é muito diferente. O adulto vem cansado do trabalho... ele tá preocupado que tem que voltar pra casa depois... deixou a família dele lá... e ele é o responsável por ela... tem as "senhorinhas" que não vão chegar em casa e achar a janta prontinha... ela ainda vai ter que fazer... pra ela, pro marido, pros filhos e pra levar a marmita no outro dia... é dureza, professor... aí ela tem mais dificuldade de se concentrar na aula... e tem também as dificuldades "naturais", que ela já tinha e [o fato de que] está muito tempo fora da escola... tem tudo isso...

Professor: Verdade... e o que você faz? Como que você trabalha?

MGO: Ah, eu tento não fazer aquelas aulas maçantes que só eu falo e eles escutam... tento fazer eles participarem... e lá eu dou aula de tudo (sic)... não dou 
só matemática... é tudo... Português, Ciências, História, tudo... e eu tento relacionar tudo com o dia-a-dia deles... com o mundo do trabalho... eu trago situações do diaa-dia e a gente discute... e eu vou falando da matéria "no meio" e depois a gente faz exercícios... e eles acham mais fácil... trago questões de outros lugares... concursos, por exemplo, é uma coisa (sic) que eles sempre se interessam".

Professor: $\mathrm{E}$ por que você trabalha desse jeito?

MGO: Por que eu vi que assim eles gostam mais do que as aulas em que eu só falava e mandava eles fazerem os exercícios... e também vi que assim eles aprendem "mais". (MGO, TAI-E1, PEF)

Do relato do estudante, percebemos que a contradição entre a formação que havia recebido até então e aquela que atenderia seu intento de promover uma boa formação para seus alunos, ensejou a crítica do licenciando, ou seja, a aprendizagem de matemática por si só, não era mais suficiente para satisfazer a necessidade de ensinar matemática. Era preciso aprender também como essa matemática deveria ser ensinada nos diversos contextos. No caso de MGO, esse modo de ensinar decorreu de sua experiência extracurso, mas o próprio licenciando levanta uma questão central: "Eu trabalho assim, professor, porque foi o jeito que eu vi que daria mais certo. E dá... mas eu acho que todo mundo tinha que ter as matérias aqui da faculdade pra ensinar a gente a trabalhar com todo mundo... porque não vai ser só eu que vou trabalhar com EJA" (MGO, TAI-E1, PEF). O licenciando questiona fortemente a formação que havia recebido, até então, por ela ser linear e direcionada ao aprofundamento do conhecimento matemático com muito maior ênfase à formação do matemático do que à formação do professor de matemática.

No encontro 3 pretendíamos que os licenciando percebessem que, para além de apresentar uma resposta adequada ao Problema, o processo de solução envolve um movimento de aprendizagem que supera a solução em si. Esse reconhecimento permitiria reconhecer na obra de Pólya, em discussão naquele encontro, uma preocupação com a investigação do processo de solução e não com uma "receita" para a resolução de qualquer Problema.

DFS e TLL foram os licenciandos que mais se aproximaram dessa compreensão. Os demais licenciandos indicaram reconhecer as heurísticas de Pólya como um importante recurso, já que, a exemplo do que indica JZM, "ajuda a organizar o entendimento e [a] encontrar a solução do Problema" (JZM, RTI, PEF). DFS afirma que um quadro resumo como o apresentado no livro de Pólya pode fazer com que o aluno fique frustrado "quando os passos do quadro não derem certo, como acontece no [Problema com mais de uma solução]" (DFS, RTI, PEF). A indicação de TLL de que 
devemos "tentar ensinar [a resolver Problemas] de forma não mecânica" (TLL, RTI, PEF), também parece ir ao encontro do entendimento de que seria necessário superar a apresentação de técnicas de resolução, em benefício de possibilidades de acompanhamento do processo de resolução como um todo.

O significado social de Problema como recurso de aplicação de conteúdos já ensinados ou como método de ensino de matemática foi colocado em discussão pelos licenciandos a partir da leitura, principalmente, do texto da professora Onuchic (2008). RPG, por exemplo, se atentou em seu relatório de aula para a importância dada pela autora ao Problema como instrumento de avaliação. Para a licencianda "aprender a resolver Problemas é muito importante porque nas avaliações que os alunos farão fora da escola é isso que será exigido deles" (RPG, RTI, PEF). TLL, em consideração semelhante, cita o exemplo de seus alunos, em formação profissionalizante, para afirmar que "[se] não ensinar a resolver Problemas de maneira independente os alunos sentirão dificuldades na realização de provas que são oportunidades de melhoria de vida como nos vestibulinhos (sic)". Este parece ser um indício de um sentido pessoal inicial a respeito do papel do Problema na organização do ensino em função do significado social de Problema que o reconhece como recurso de avaliação do conhecimento apropriado, ainda que esse sentido pessoal, nesse caso, ainda esteja relacionado a um processo avaliativo, aparentemente, descolado do movimento formativo como um todo.

Foi após esses primeiros encontros que apresentamos a situação desencadeadora de aprendizagem Carta Caitité. Os licenciandos foram organizados em grupos e foram convidados a resolver o Problema (todos encontraram uma solução) e a apresentar uma proposta de organização da aula. As sínteses de grupo, entregues ao professor, permitiram identificarmos que os licenciandos, de modo geral, entenderam que o professor que proporia essa SDA deveria reconhecer o que constitui a essência do conceito de sistema de numeração organizado segundo uma base numérica e de forma posicional, bem como para a importância do zero em um sistema de numeração com aquelas características.

A proposta de aula do grupo que contava com a participação de TLL, indicava que - Problema deveria ser apresentado após as aulas em que os alunos aprendessem a realizar "mudança de base" numérica, durante o ensino fundamental. A justificativa 
contida na proposta era a de que essa capacidade (de mudar números de uma base para outra, no caso da base decimal para uma base 4) era essencial para que os alunos pudessem resolver o Problema. Entendemos que os licenciandos do grupo, incluindo TLL, entendiam ser importante a organização da aula a partir do domínio prévio de técnicas de resolução. Os alunos, apesar de reconhecerem a necessidade de uma base de agrupamento e as importâncias das características posicionais e de representação do zero, não remeteram sua proposta à aprendizagem do nosso próprio sistema de numeração, mas entenderam, ao contrário, ser necessário já dominá-lo para poder solucionar o Problema.

Por outro lado, a proposta do grupo em que participavam PNL, JZM e ISC foi uma proposta de aula para o ensino da operação aritmética de adição. Nas palavras do relatório entregue pelo grupo, seria um Problema "interessante para entender a ideia do 'vai um'” (PNL, JZM, ISC e outros, RTC-G, PEF). Os licenciandos sugerem que os alunos já saberiam a operação de adição, mas de maneira mecânica, sem poderem entender a razão do "vai um" que acontece quando a soma em alguma das ordens ultrapassa a contagem da dezena. No caso da Carta Caitité, o "vai um" ocorreria nos agrupamentos de quatro elementos. Os licenciandos sugerem, inclusive, criar um "material dourado Caitité" em que os alunos poderiam associar a representação simbólica com a quantidade correspondente e poder assim, não só responder ao Problema, como reconhecer a ideia de agrupamento. Entendemos que a proposta desse grupo já se aproximou mais de um entendimento de aprendizagem de um conceito a partir da necessidade suscitada por um Problema. A proposta fala, em alguns momentos, em "entender o que eles sempre fizeram" (PNL, JZM, ISC e outros, RTC-G, PEF), quando trata das ideias sobre "vai um". Os outros dois grupos, aquele em que estavam RPG e DFS e o que estava MGO, apresentaram propostas que remetiam à aprendizagem da forma de organização do nosso sistema de numeração, mostrando maior preocupação com as características de sistematização da aula, indicando que fariam a proposição do Problema para os alunos resolverem e, depois que todos tivessem resolvido, fariam a "correção". Nenhum dos dois grupos indicou aspectos relacionados ao acompanhamento do movimento de solução do Problema. Inferimos desse silêncio que os licenciandos poderiam estar compreendendo, naquele momento, que a correta resolução do Problema, seja realizada pelo próprio 
aluno ou acompanhando um terceiro realizando, seria suficiente para a aprendizagem dos conceitos nele impregnados.

Consideramos importante, ainda, destacar que apenas o grupo em que estava TLL indicou algum aspecto da organização da turma em que desenvolveria a proposta, indicando que proporiam que os alunos resolvessem o Problema individualmente e que a "correção" seria realizada coletivamente, na lousa. Isso seria indício de sentidos que compreendem o trabalho coletivo como empecilho para a aferição da aprendizagem individual, já que, na proposta em grupo, propõe-se evitar que "os alunos que sabem a matéria fazem e os demais não têm a oportunidade de participar também" (TLL e outros, RTC-G, PEF).

Nossa pesquisa indicou, a partir de nossa análise dos dados decorrentes das discussões posteriores sobre a Carta Caitité que esta é uma SDA que apresenta um Problema que coloca o aprendiz diante da necessidade de apropriação daquilo que foi essencial na constituição histórica do conceito de sistema de numeração.

A partir dos indícios a respeito dos sentidos pessoais dos licenciandos que verificamos, podemos supor que estes estavam relacionados às suas vivências pessoais, seja durante o processo de escolarização básica ou mesmo, após seus ingressos na graduação, em suas experiências nas diversas disciplinas já cursadas durante a licenciatura. Não tendo havido para nenhum dos sete licenciandos, formação específica voltada para uma reflexão teórica acerca do papel do Problema em suas práticas profissionais, entendemos que tais sentidos pessoais iniciais remetem a uma compreensão de estrito senso comum, decorrente do discurso presente no processo formativo que reconhece o Problema como importante na prática docente em razão da afirmação genérica que seria papel do professor ensinar a resolver tais Problemas.

De modo geral, podemos resumir os sentidos pessoais iniciais dos licenciandos da seguinte forma:

RPG compreendia que o Problema deve ser apresentado à turma antes de "explicar" o conteúdo. Depois de apresentado o Problema o professor iria fazendo perguntas diretivas para que os alunos possam encontrar a solução. Compreendia que o Problema serviria como desafio inicial para despertar o interesse dos alunos pela matéria. 
JZM, mostrou indícios de sentidos iniciais segundo os quais o Problema cumprisse o papel de desafio, seria uma forma de "dar uma aula diferente". Ela compreende que resolver um Problema seria diferente de só resolver as questões, pois resolver Problemas indica como o conteúdo vai ser aplicado no dia-a-dia.

Já DFS, indicou que o Problema deveria abordar a matéria que estivesse sendo estudada, com o propósito de resolver problemas do dia-a-dia e que deveriam ser apresentados em um contexto (uma narrativa) que pudesse ser resolvida aplicando o conteúdo estudado.

PNL compreendia que o Problema devia remeter a situações da realidade e ajudar os alunos a estar preparados para resolver os Problemas de avaliações diversas, como concursos e vestibulares.

TLL indicou que o Problema devia ser selecionado de acordo com o conteúdo que o aluno devia aprender. Em sua perspectiva, o professor devia conhecer e estar preparado para resolver uma série de Problemas que proporia aos alunos, mas estes deviam tentar resolver, antes, sozinhos qualquer proposta apresentada pelo professor. No entanto, caberia ao professor a tarefa de indicar os caminhos de solução, de modo que o aluno aprenderia se ele próprio resolvesse ou mesmo se visse outra pessoa resolvendo.

ISC indicava inicialmente que compreendia que os Problemas têm caráter de aplicação do conteúdo ensinado, sendo situações que remetem à "realidade". No entanto, já no movimento da etapa exploratória pré-experimento formativo, demonstrou indício de um movimento em seu sentido pessoal inicial, relatando uma regência de estágio com uma proposta que se aproxima de uma compreensão do Problema como desencadeador de aprendizagem. Trataremos desse movimento de ISC em nossas conclusões, mais adiante.

MGO indicou que o Problema devia ser uma aplicação do conteúdo na "realidade", principalmente em relação ao mundo do trabalho, tanto na EJA (em que atua) como em relação à preparação do jovem para o mercado de trabalho e o mundo profissional, como a realização de concursos.

Esses sentidos pessoais iniciais estão sintetizados no quadro 6, em que os organizamos em duas categorias: a caracterização do Problema e as implicações dos 
sentidos pessoais na organização do ensino. Essas duas categorias foram subdivididas em quatro e três subcategorias, respectivamente.

Quadro 6: Sentidos pessoais iniciais de licenciandos sobre Problema

\begin{tabular}{|c|c|c|c|c|c|c|c|}
\hline \multirow[b]{3}{*}{ Licenciando } & \multicolumn{7}{|c|}{ Sentidos pessoais iniciais sobre Problemas } \\
\hline & \multicolumn{4}{|c|}{ Características do Problema } & \multicolumn{3}{|c|}{$\begin{array}{l}\text { Implicações para a } \\
\text { organização da aula }\end{array}$} \\
\hline & 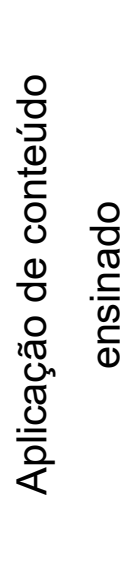 & 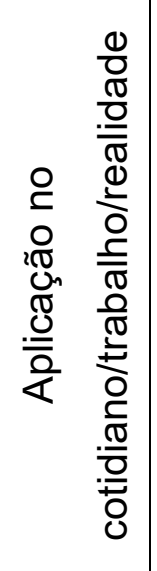 & 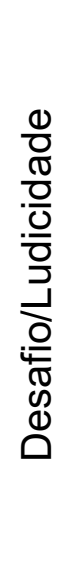 & 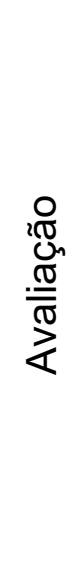 & 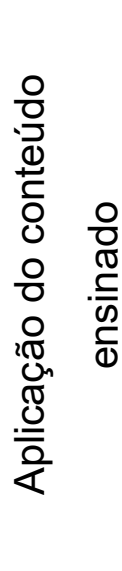 & 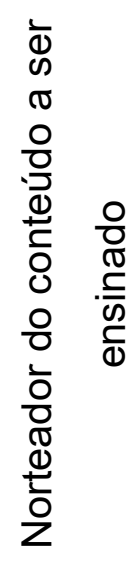 & 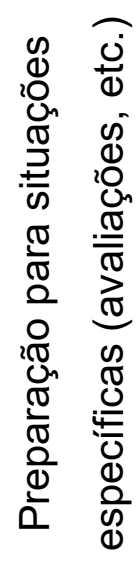 \\
\hline RPG & & & $x$ & & & $x$ & \\
\hline JZM & & $x$ & $x$ & & & $x$ & \\
\hline DFS & $x$ & $x$ & & & $x$ & $x$ & \\
\hline PNL & & $x$ & & $x$ & $x$ & & $x$ \\
\hline TLL & $x$ & $x$ & & & $x$ & $x$ & \\
\hline ISC & $x$ & $x$ & & & $x$ & & \\
\hline MGO & & $x$ & & $x$ & $x$ & & $x$ \\
\hline
\end{tabular}

Fonte: Elaborado pelo autor a partir dos dados coletados em áudio

Como pudemos verificar, os sentidos pessoais iniciais dos licenciandos relacionavam-se, de modo geral, com um significado de Problema que remete à aplicação 
de lições anteriormente ensinadas, são compostos por narrativas que ilustram a aplicação direta de um algoritmo, propriedade ou definição, ou possuem caráter pragmático, ou seja, são simulações de aplicação do conteúdo em estudo em situações que poderiam acontecer na "realidade" (assim entendida, ao que as falas indicam, os ambientes não relacionados à escola) ou demandadas pela vida social, como a aprovação posterior em vestibulares, concursos ou avaliações externas.

Passamos, a seguir, a tratar dos nossos isolados e episódios a fim de que evidenciar o movimento dos sentidos pessoais sobre Problemas dos licenciandos que analisamos. O quadro 7 retoma sinteticamente esses isolados e episódios, conforme apresentamos no subcapítulo 3.2 .

Quadro 7: Apresentação de isolados e episódios

\begin{tabular}{|c|c|c|c|}
\hline \multicolumn{2}{|c|}{ Isolado } & \multicolumn{2}{c|}{ Episódios } \\
\hline A & O Problema na organização da AOE & A1 & $\begin{array}{c}\text { Reconhecimento da necessidade da } \\
\text { necessidade }\end{array}$ \\
\cline { 3 - 4 } B & $\begin{array}{c}\text { O PDA e a História da matemática na } \\
\text { organização da atividade pedagógica }\end{array}$ & B1 & $\begin{array}{c}\text { Superação da proposição de } \\
\text { Problemas "prontos" }\end{array}$ \\
\hline C & $\begin{array}{c}\text { O PDA e o movimento dos sentidos } \\
\text { pessoais dos licenciandos sobre o } \\
\text { Problema }\end{array}$ & C1 & O PDA no planejamento da SDA \\
\cline { 3 - 4 } & $\begin{array}{c}\text { C2 } \\
\text { do conceito }\end{array}$ & $\begin{array}{c}\text { Problemas na regência de estágio: } \\
\text { uma aproximação com o PDA }\end{array}$ \\
\hline
\end{tabular}

Fonte: Elaborado pelo autor

\subsection{O protagonismo do Problema na organização da AOE.}

Como indicamos no subcapítulo 3.2 , no experimento formativo os licenciandos foram agrupados segundo aproximações que verificamos entre o que haviam desenvolvido em suas regências de estágio e três categorias principais, a saber: situações emergentes do cotidiano, o contexto de jogos e o envolvimento de aspectos históricos. Essa organização dos grupos remete às maneiras mais usuais de materialização das SDA, de acordo com Moura e Lanner Moura (1998). A partir dessa organização acompanhamos o movimento dos sentidos em situações em que os 
licenciandos discutiam no contexto do próprio grupo, nos momentos de socialização ou nos relatórios escritos que apresentavam.

Quadro 8: Agrupamento para o experimento formativo

\begin{tabular}{|c|c|c|}
\hline Grupo & Licenciandos & Critério de agrupamento \\
\hline$x$ & $\begin{array}{l}\text { TLL } \\
\text { ISC } \\
\text { MGO }\end{array}$ & $\begin{array}{l}\text { Os Problemas utilizados remetiam às necessidades } \\
\text { históricas do conceito que pretendiam ensinar }\end{array}$ \\
\hline$Y$ & $\begin{array}{l}\text { PNL } \\
\text { JZM }\end{array}$ & $\begin{array}{c}\text { Indicaram como Problema, na regência final da primeira } \\
\text { etapa, um jogo. }\end{array}$ \\
\hline Z & $\begin{array}{l}\text { RPG } \\
\text { DFS }\end{array}$ & $\begin{array}{l}\text { Adotaram Problemas que tinham o intuito ensinar um } \\
\text { conceito a partir de uma situação que consideraram } \\
\text { emergente do cotidiano. }\end{array}$ \\
\hline
\end{tabular}

Fonte: Elaborado pelo autor

O primeiro isolado que identificamos remete ao protagonismo do Problema na organização da AOE. Na atividade pedagógica "o objetivo do professor é levar a criança a dar forma teórica à solução de um problema em uma situação de aprendizagem, que é considerada como um problema de aprendizagem" (CEDRO, 2004 apud MOURA, SFORNI e ARAÚJO, 2011, p. 40). Sendo assim, como já indicamos, não podemos entender que qualquer questão possa ser considerada um Problema Desencadeador de Aprendizagem apenas por exigir a aplicação direta de definições, propriedades ou técnicas específicas de resolução. Este deve suscitar no aluno a necessidade que se assemelhe à necessidade que levou a humanidade a produzir o mesmo conceito.

Nesse contexto, os sentidos pessoais de alguns licenciandos que compreendiam o Problema como recurso de aplicação pressupunha uma atuação docente que deveria apresentar definições, propriedades e algoritmos e, geralmente, alguns modelos em que o professor demonstraria a aplicação. Essas lições seriam, posteriormente, aplicadas para a resolução de situações similares aos modelos apresentados previamente. Dessa forma, o Problema desempenharia um papel mais próximo da verificação (avaliação) da eventual aprendizagem, e não o de desencadeá-la. 
Assim, a partir do reconhecimento do Problema como elemento capaz de suscitar nos alunos a necessidade de apropriação dos conceitos a serem estudados e a importância da superação da adoção de Problemas "prontos" selecionados a partir de recursos didáticos, como o livro, identificamos este primeiro isolado que destaca os aspectos que parecem indicar um movimento dos sentidos dos licenciandos convergindo para a compreensão do Problema como desencadeador da aprendizagem, superando a compreensão deste apenas como um recurso avaliativo.

\subsubsection{Episódio A1: O reconhecimento da necessidade da necessidade.}

Este episódio emerge, especialmente, das discussões realizadas no Encontro 2, em que solicitamos que os licenciandos elaborassem um "plano de aula" que tivesse como objetivo ensinar o conceito de Juros Simples a uma turma fictícia do primeiro ano do Ensino Médio, na Educação de Jovens e Adultos, em uma escola pública. A partir dessa proposta o grupo Z, em que participavam as licenciandas RPG e DFS - além de outros dois licenciandos -, a pedido do professor, apresentou para os demais grupos sua proposta, sendo representado pela licencianda DFS.

DFS: Nós resolvemos que a melhor forma de começar a aula sobre Juros Simples em uma turma de EJA era trazer uma situação da realidade deles. Então decidimos falar sobre uma coisa que é aquele carnê da Previdência Social, que os autônomos pagam.

Professor: Ok. Legal. Mas aquele carnê faz parte da realidade de todo mundo? DFS: Não. Acho que só das pessoas que pagam como autônomo... Mas é algo que a gente consegue explicar mais fácil o que é... consegue imagens pra mostrar pra eles... e eles podem pesquisar no dia-a-dia deles e encontrar.

(DFS, TAC-GZ-E2, EF)

Os integrantes do grupo parecem ter seguido uma tendência ligada aos sentidos pessoais iniciais de DFS e RPG sobre as características de um bom Problema a ser utilizado em sala de aula, segundo a qual estes devem, tanto quanto possível, remeter a situações ligadas à realidade do aluno. No entanto, a proposição trata de apresentar uma situação que esteja relacionada a esta realidade, mas, primordialmente, em um contexto de possibilitar uma aplicabilidade. Esta consideração é importante para compreendermos a contradição suscitada pelos colegas licenciandos, na sequência.

Questionados sobre como organizariam a aula em si, DFS explica o que ela chama de "pauta do dia", que é, na verdade, a sequência de ações que o professor seguiria até a apresentação do Problema para os alunos resolverem. Segundo aquele relato, eles 
tratariam de realizar uma "revisão" sobre porcentagem, propondo exercícios para o cálculo direto de porcentagens. DFS explica que essa revisão seria necessária, porque os alunos aplicariam o cálculo de porcentagens para o cálculo de juros.

DFS: Nós colocamos aqui [na folha de registro da proposta]... primeiro a gente apresentaria para a turma o que vamos fazer... que é a pauta do dia... depois a gente faz uma revisão dos conceitos e aplicações de porcentagens... aí...

Professor: [interrompendo] e o que seriam essas aplicações de porcentagens que vocês fariam primeiro?

DFS: Ah... tipo, uma revisão de porcentagem mesmo. Pra ver se eles lembram como se calcula porcentagem.

Professor: Entendi... exercícios mesmo... de cálculo direto...

DFS: Sim. Isso... porque eles vão ter que aplicar o cálculo de porcentagem pra calcular os juros.

DFS: Então, depois disso a gente apresentaria o Problema da GPS, que é a [consultando a ficha] "Guia de Previdência Social"... esse Problema fala que o pagamento deve ser feito até o vencimento, mas se não for é cobrada uma taxa de juros pelo atraso. Eles têm que calcular esses juros. Depois que eles resolverem, eles apresentam a resposta deles na lousa ou oralmente mesmo... e, depois, fazemos a correção na lousa, apresentando a resposta para eles compararem com a que eles encontraram...

(DFS, TAC-GZ-E2, EF)

A essa altura, já havia ficado claro, a nosso entender, que a proposição do grupo remeteria à aplicação de um conceito matemático (porcentagem) que seria importante para os cálculos referentes a outro conceito (Juros). A situação que o grupo apresentou como Problema que subsidiaria o ensino do conceito de Juros foi a seguinte:

O pagamento do GPS precisa ser realizado nas datas de vencimento da conta ou anterior a isso. Porém, se o pagante atrasa o pagamento, para cada dia de atraso, é cobrado um valor fixo pelo atraso. Isso decorre por conta das transações que o banco recebedor precisa realizar com o capital do pagamento do GPS e, caso haja atrasos, precisa ser reposto, porém também por conta das alterações dos valores financeiros do mercado. Supondo que o pagante atrasou 0 pagamento em 30 dias e a cobrança é de $0,33 \%$ do valor a ser pago. Considere que o valor a ser pago seja de $20 \%$ do salário mínimo, qual será o valor pago pelo atraso? Quanto o pagante terá que pagar no próximo vencimento da conta? [Dados] Salário mínimo: R\$ 937,00. (DFS, RTC-GZ-E2, EF).

A contradição, no entanto, foi apontada pelos próprios licenciandos, quando o professor convida os integrantes dos demais grupos para apresentarem considerações acerca da proposta do grupo Z. Destacamos um trecho de um debate protagonizado pelas licenciandas RPG, DFS e pelo licenciando MGO:

MGO: Eu acho uma boa proposta. Porque traz uma coisa que é da realidade dos alunos... no (sic) EJA eles gostam disso... mas acho que ficou parecendo que é só sobre porcentagem... 
RPG: [interrompendo] também pensamos isso, mas é que tem que ser uma proposta de introdução do assunto [juros simples]... então a porcentagem é importante...

MGO: Sim, mas aí a proposta era falar de juros simples e falou de porcentagem... Professor: E você acha que fugiu do tema?

MGO: Sim, professor. Porque se a pessoa não entender o que é juros, mesmo assim ela consegue resolver o Problema só aplicando as porcentagens... que ela revisou no começo da aula...

DFS: Sim, mas depois da resposta dos alunos, durante a correção, a gente fala a definição de juros.

Professor: Ah, mas é legal essa questão. A resolução do Problema é necessária para compreender a ideia de juros? Ou os alunos só vão entender porque vocês vão apresentar a definição formal?

RPG: [ajudando a colega do grupo] Acho que precisa apresentar a definição, professor... porque quando o aluno resolve o Problema, ele não sabe o que é juros... só sabe fazer porcentagem... então, depois a gente fala pra ele o que é juros e relaciona com a porcentagem.

(DFS e RPG, TAC-GZ-E2, EF ; MGO, TAI-E2, EF)

MGO indica o que já havíamos identificado como parte de seu sentido pessoal inicial ao reconhecer a importância de o Problema tratar de uma situação "da realidade", remetendo-se, inclusive à própria experiência com turmas de EJA para sustentar que "eles gostam disso [situações do cotidiano]", mas levanta a ressalva quanto ao propósito do Problema. Enquanto a proposta girava em torno de apresentar um Problema que pudesse ser usado na introdução de um novo conteúdo, o grupo, no entendimento de MGO, com o qual concordamos, propôs uma situação que buscava aplicar um conteúdo já ensinado (e revisado, portanto, não novo).

RPG admite que essa questão (sobre o Problema tratar de porcentagem e não sobre Juros) perpassou as interações do grupo e DFS ratifica que a proposta girava em torno de aguardar que os alunos resolvessem (aplicando porcentagem) e depois seria apresentada a própria definição de Juros. O entendimento inicial, do que se pode compreender a partir da fala de RPG - "acho que precisa apresentar a definição, professor... porque quando o aluno resolve o Problema, ele não sabe o que é juros... só sabe fazer porcentagem... então, depois a gente fala pra ele o que é juros e relaciona com a porcentagem" (RPG, TAI-E2, EF) - buscava enfatizar a aplicação das porcentagens no cálculo de taxas de Juros. A intervenção do professor, então, visa possibilitar um movimento nesse sentido. Quando questiona se a resolução do Problema é necessária para a compreensão do conceito de Juros, o professor está indicando que, dada a revisão de porcentagens proposta para o início da aula e a apresentação formal da definição posterior, haver ou não o Problema, da forma como foi proposto, não faria diferença para 
o propósito da aula. Em outras palavras, indica que o Problema que foi proposto, na verdade seria apenas mais um dos exercícios de aplicação de porcentagens que poderia estar no contexto da revisão que já havia sido feita.

Os próprios licenciandos iniciam a reflexão sobre uma possível síntese:

Outro licenciando (PTO, do mesmo grupo de MGO): E se vocês falassem no Problema... ali naquele começo quando fala que o pagamento da guia precisa ser feito em dia... por que precisa pagar em dia?... [respondendo a própria pergunta] porque o dinheiro desvaloriza com o tempo e no dia que paga atrasado o dinheiro vale menos do que se tivesse pagado em dia...

Professor: Mas aí o aluno só resolveria se soubesse o conceito de juros?

RPG: Não... ele vai continuar resolvendo do mesmo jeito... só vai mudar o enunciado, mas ele vai resolver com porcentagem do mesmo jeito.

(PTO, TAI-E2, EF ; RPG, TAI-E2, EF)

Apesar de não ter mudado a essência do Problema, a intervenção de PTO propõe uma alteração na situação que visasse incluir no próprio enunciado a ideia central a respeito do conceito de Juros. De acordo com Santos (2005) e Robert (1989), a origem histórica dos Juros remete à necessidade de remuneração sobre um capital em função do tempo em que este fica indisponível. A consideração de PTO parece ir ao encontro dessa ideia ao propor que, ao invés de apresentar posteriormente a definição, o próprio enunciado apresentasse alguma informação que se aproximasse dela, a partir de uma relação com a essência histórica do conceito.

Essa consideração, como bem indicou RPG, não mudaria a situação, pois o aluno continuaria resolvendo aplicando porcentagem e apenas leria a definição de um novo conceito. Seria o mesmo que se apresentasse a definição antes da resolução e não mais depois, mas, de toda forma, a apresentaria.

O professor, considerando a aparente aceitação de RPG, integrante do grupo Z, de que haveria um problema no Problema, que remeteria à possibilidade de resolvê-lo sem conhecer o novo conceito que se pretendia ensinar, insiste na questão sobre a necessidade de se conhecer o conceito de Juros para resolver o Problema, mesmo após a proposta de alteração apresentada por PTO.

Professor: E, será, que teria uma forma de reelaborar o Problema, pra ser necessário entender a ideia de juros para resolver?

DFS: Mas precisa mudar [na ficha de registro]?

Professor: Não... só se vocês quiserem. Estamos imaginando que é uma aula que vocês vão dar... e os colegas acham que poderia melhorar... mas vocês podem entregar como está. [silêncio] 
(DFS, TAI-E2, EF)

Diante da provocação do professor sobre uma possível reformulação do Problema, DFS indica uma preocupação secundária, mas que, ao que parece, inibe os demais colegas quanto a apresentação de sugestões. Ela parece compreender que as críticas sobre a proposta do grupo estariam indicando que o Problema deles estaria "errado" e questiona se precisaria mudar. A resposta do professor busca minimizar a importância da "entrega" da ficha (entendida como um instrumento de avaliação e, portanto, relacionado à nota). Todavia, os demais licenciandos não apresentaram outras sugestões. O professor, então, apresenta uma proposta, mas não como "correção" para o Problema, mas como provocação sobre o que esta alteração acarretaria na proposta.

Professor: E se fizesse a alteração que o PTO sugeriu e retirasse a parte que pede o cálculo e colocasse uma pergunta assim: "como poderíamos compensar a desvalorização em um pagamento atrasado?”. Vocês acham que mudaria? [breve silêncio]

DFS: Acho que sim. Porque aí o aluno vai pensar que tem que cobrar mais caro, porque no dia-a-dia deles eles já sabem que quando paga atrasado, paga mais caro...

PTO: [interrompendo] sim... e essa é a definição de juros.

(DFS e PTO, TAI-E2, EF)

A proposta do professor se aproxima de uma compreensão segundo a qual a apresentação de uma situação emergente do cotidiano (uma SDA) pode suscitar, a partir de uma provocação (o PDA), a necessidade de apropriação de um conceito. Ainda que DFS tenha ressaltado que a solução para o Problema - sobre como se poderia compensar a desvalorização em um pagamento atrasado - possa ser conhecida a partir da experiência prévia dos alunos, a proposição de alteração retira do Problema a mera aplicação de porcentagens e deposita o foco na compreensão do que seriam Juros, sem que o professor precise "apresentar", a priori, a definição, mas sim fazer com que os alunos entrem em um movimento que poderia culminar na aprendizagem do conceito até poderem defini-lo. Esse movimento se aproxima daquele que foi feito pela humanidade e que culminou no significado de Juros, de acordo com Santos (2005) e Robert (1989), e poderia potencializar que os alunos entrassem a atividade.

A solução do Problema não pode, por si mesma, garantir a apropriação do conceito em estudo. Fosse assim, bastaria apresentar aos alunos relações de Problemas impregnados de necessidades conceituais e a aprendizagem de tais conceitos estaria 
garantida ao final do processo. Mas o movimento de ensino e de aprendizagem que se dão no contexto da AOE demonstra que a apropriação do conhecimento é um processo mediado. Nesse contexto ao planejar a SDA, compreendida, como já tratamos, como as situações que visam desencadear um movimento que permita que o aluno entre em atividade de aprendizagem e o professor entre em atividade de ensino, o professor propõe um PDA que tem como característica principal a necessidade de apropriação conceitual para sua solução. No entanto, a mera apresentação de tal Problema à turma não garante que a apropriação do conceito tenha sido realizada, já que o movimento é realizado no contexto de uma situação mediada.

A licencianda DFS parece reconhecer que a alteração sugerida muda a perspectiva da atuação do professor, já que este superaria o papel de transmissor de conhecimento, que ensina antes, propõe situações similares para os alunos reproduzirem aquilo que ele próprio realizou, e corrige erros posteriormente, momento em que aproveita para apresentar a definição formal. Esse movimento, tanto autoritário quanto tradicional, parece se descortinar na mente da licencianda na compreensão de que seu reconhecimento sobre a importância da presença de situações que emergem da realidade no processo de ensino e de aprendizagem devem superar a mera proposição de situações que narrem situações do cotidiano, mas que também possibilitem que os conhecimentos trazidos desse cotidiano possam ser mobilizados para a solução do Problema e para a aprendizagem de um conceito novo, sem a necessidade de apresentação explícita da definição. A conclusão de que, a partir da alteração sugerida pelo professor, "o aluno vai pensar que tem que cobrar mais caro, porque no dia-a-dia deles eles já sabem que quando paga atrasado, paga mais caro" (DFS, TAI-E2, EF) é um indício de que os sentidos da licencianda, em relação à sua compreensão sobre a importância de o Problema emergir de situações cotidianas ganha destaque nos modos de organização do ensino se o Problema não só remeter a situações cotidianas em seu enunciado, mas também se mobilizar essas necessidades cotidianas no movimento que compõe toda a SDA, incluindo o processo de busca de uma solução para o Problema, a partir da qual poderá mediar a apropriação do conceito.

Em síntese, as discussões sobre a proposta do grupo $Z$ indicaram um movimento em que se aproximam os conceitos de porcentagem e de Juros. Esse movimento, por 
vezes, permanece impregnado em uma "confusão" entre os conceitos, de modo que não se compreende a distinção entre taxa de juros (porcentagem) e juros propriamente ditos. RPG parece ter compreendido que o Problema proposto pelo grupo tinha um problema, qual seja, não suscitava a necessidade de apropriação do novo conceito que pretendiam ensinar, mas apenas a oportunidade de aplicação de técnicas de cálculo já aprendidas.

A intencionalidade destacada por Moura, et al. (2017, p. 84) como um dos aspectos que caracterizam a $\mathrm{AOE}$, de modo que professor e aluno se reconheçam como sujeitos da atividade e possam refletir sobre o "caráter voluntário de suas ações, bem como o estabelecimento de um plano interno para realizá-las" se evidencia quando, a partir da contribuição dos colegas, principalmente MGO e PTO, além do professor, RPG passou a reconhecer a necessidade de o Problema suscitar a necessidade de apropriação conceitual. Essa é a conclusão que estamos denominando neste episódio de "reconhecimento da necessidade da necessidade". Esse reconhecimento é um indício de que o Problema original proposto pelo grupo $Z$, que remetia ao sentido inicial de que as situações que emergem da realidade seriam contextos para a aplicação das lições a serem ensinadas, poderia ser reelaborado, passando a suscitar uma necessidade de apropriação do conceito, de modo que a referida intencionalidade do professor poderia colocar os alunos em atividade. O Problema poderia, então, ser reconhecido como desencadeador de aprendizagem.

Ainda na síntese, e nesse mesmo contexto, pudemos verificar um movimento de sentidos das licenciandas do grupo $Z$, de que o cotidiano não suscitaria apenas situações em que os conceitos aprendidos poderiam ser aplicados, mas também, e sobretudo, pode suscitar situações que tragam consigo a necessidade, ou seja, a situação que possa apresentar um Problema que colocará o aluno em um movimento de aprendizagem do conceito que se pretende ensinar. O cotidiano, compreendido como contexto social do professor em formação, deixa de ser fonte de inspiração apenas para a aplicação daquilo que já foi ensinado, e passa a ser fonte de situações que tragam para a atividade a necessidade que, suscita motivos e potencializa que o aluno entre em atividade. Assim, nós apresentamos essa compreensão para a afirmação de que as situações emergentes do cotidiano podem suscitar SDA em complemento àquela que seria a compreensão de Moura e Lanner Moura (1998) quando indicam o cotidiano como situações ocorridas no 
contexto da própria prática pedagógica, em sala de aula. Com isso, estamos afirmando que, para além das situações cotidianas compreendidas a partir do contexto da escola, como compreendidas por Moura e Lanner Moura (idem), as situações emergentes do cotidiano social geral podem ser percebidas pelo professor como fontes para elaboração de SDA e, consequentemente, de bons PDA.

\subsubsection{Episódios A2: Superação da proposição de Problemas "prontos".}

O segundo episódio, A2, do primeiro isolado decorre da análise possibilitada pelos dados produzidos e coletados a partir do Encontro 8 em que os grupos deveriam realizar o que chamamos de "tipificação" de Problemas, em que recebiam uma relação com inúmeros Problemas extraídos de diversas fontes, como provas de avaliações em massa, de olimpíadas de matemática, de concursos públicos, de livros didáticos, etc. Os licenciandos deveriam então, a partir da leitura de texto adaptado de Dante $(1998 ; 2009)$ que apresenta alguns "tipos" de Problemas, classificar aqueles apresentados na lista de acordo com esses "tipos". Depois deveriam escolher um dos Problemas e elaborar uma proposta de aula que o utilizasse. Também analisamos dados que advém do Encontro 9 em que os licenciandos foram convidados a analisar livros didáticos em busca de Problemas que pudessem contribuir para a organização da regência de estágio, no contexto que vínhamos trabalhando. Nesses encontros 8 e 9 verificamos o que entendemos como o reconhecimento da necessidade de superação da mera proposição de Problemas contidos em livros didáticos sob a alcunha de trabalho com resolução de Problemas. Passamos a apresentar os dados.

No Encontro 8 que tratou da tipificação dos Problemas, os licenciando realizaram em grupos a tarefa proposta e foram convidados a compartilhar suas considerações a todos os demais alunos. A contradição decorrente de distintas classificações para o mesmo Problema ocasionou a seguinte conversa:

ISC: Nós entendemos no grupo $[\mathrm{X}]$ que quase todos os Problemas podem ser classificados com quase todos os tipos...

DFS: [interrompendo] nós também, professor... [é] muito genérico [a classificação por tipos]. Cada Problema pode ser de reconhecimento, de algoritmo, problemaspadrão [citando os tipos enquanto consultava o texto escrito]... pode ser qualquer coisa... não dá pra saber...

Professor: Mas não precisa ser um tipo só... pode ser vários...

DFS: Mas são todos... (risos) 
ISC: Então... também achamos isso aqui [no grupo X] ... e então a gente não sabe se tá certo...

Professor: Mas não tem "certo" ou "errado"...

ISC: Mas porque a gente ia classificar, se qualquer classificação serve?

Professor: Boa pergunta! Por que?

Outro licenciando (LNS, membro do grupo Z): Acho que é porque se a gente classificar os Problemas desse jeito que está aqui [referindo-se ao texto], fica mais fácil de os alunos resolverem.

(ISC, TAC-GX-E8, EF ; DFS, TAC-GZ-E8)

Àquela altura, ao que parece, os licenciandos estavam questionando o propósito da SDA da docência em que eles próprios estavam envolvidos. A proposição da tipificação foi compreendida como incoerente pelos licenciandos do grupo $\mathrm{X}$, a princípio, pois a classificação dos Problemas de acordo com tipos não contribuía para a seleção destes para serem utilizados em aula. Em outras palavras, os licenciandos não compreendiam que o ato de tipificar Problemas seria importante para o planejamento de uma aula, pois, segundo o que podemos concluir de suas considerações, colocar qualquer um dos tipos propostos ${ }^{25}$ no texto não alteraria a proposta de organização de uma aula. LNS indica perceber que a tipificação dos Problemas serve apenas como indicativo das técnicas de solução a serem aplicadas. Mas essa conclusão ainda não relaciona, ao que parece, a tipificação aos sentidos dos licenciandos sobre Problemas.

TLL: O problema pra gente foi porque, dependendo de como você olha, qualquer um pode ser qualquer tipo desses aqui... eu acho que teria que ter tipos que os diferenciasse...

RPG: A gente criou outros tipos, professor...

Professor: Que tipos vocês criaram?

DFS: [procurando na folha de registro o novo tipo criado]... na [questão número] 8, por exemplo, nós colocamos que é "de aplicação" de proporção [aplicação de conceito], mas também dá pra resolver sem aplicar o algoritmo, só com raciocínio lógico, então colocamos "barra raciocínio lógico"... mas dá até pra dizer que nem tem resposta, porque, quem garante que o operário receberia o mesmo valor todos os dias? Ele poderia fazer serviços diferentes e receber valores diferentes a cada dia.

(TLL, TAC-GX-E8, EF ; RPG, TAC-GZ-E8 ; DFS, TAC-GZ-E8)

Figura 12: Resposta Grupo Z, questão 8

8. Um operário recebeu $\$ 170.000$ por alguns dias de serviço. Se tivesse trabalhadó mais 7 dias receberia \$229.500. Quantos dias ele trabalhou? Racióno logío / A plicacão de concito

${ }^{25}$ A saber: Problemas de reconhecimento, Exercícios de algoritmos, Problemas-padrão; Problemasprocesso ou heurísticos, Problemas de aplicação e Problemas quebra-cabeça, de acordo com Dante (1998, p. 16 a 21) 
Fonte: Resposta do grupo na folha de registro e digitalizado pelo autor

A consideração de DFS configura, para nós, um indício de um movimento do sentido pessoal que supera a mera aplicação do conceito e passa a reconhecer a necessidade que ele suscita. Ao questionar a redação do Problema e problematizar que os operários poderiam receber remunerações diferentes a cada dia (por exemplo, se realizassem trabalhos de diferentes complexidades) a licencianda parece colocar em xeque a aplicabilidade do conceito (proporção) e atrelar a possíveis análises (que ela chama de "raciocínio lógico") que tendem a verificar como o Problema poderia suscitar necessidades, ou seja, como o Problema poderia suscitar um debate a respeito de ideias relacionadas ao conceito de proporção, já que, como é verificável, a resposta esperada para o Problema decorre da suposição que a remuneração é proporcional, mas se o Problema não se limitar à resposta específica solicitada, poderia suscitar uma discussão que poderia conduzir ao debate sobre o fato de ser ou não a remuneração proporcional, envolvendo, assim, o conceito de proporção na análise do Problema (na sua compreensão).

Incentivando a continuidade do debate, o professor prossegue:

Professor: Ah... que legal... e quantos tipos "novos" vocês criaram?

RPG: Só esse [raciocínio lógico], porque tem questões que nem tem resposta, então não é de nenhum desses tipos... e a gente colocou como "de raciocínio lógico", porque é o raciocínio que mostra que não tem resposta.

Professor: Então vocês criaram esse novo tipo para usar nessas questões?

RPG: Sim... também... mas usamos em outras questões também... que têm resposta, mas que pode ser resolvido só com lógica.

Professor: Legal. Alguém mais criou algum tipo diferente dos que tinham no texto?

TLL: Nós não criamos porque os que tinham aqui já eram "demais"... (risos)... raciocínio lógico também se aplica a todos os Problemas daqui... e esse é o problema... essa classificação não ajuda em nada porque qualquer tipo pode ser aplicado a quase todos os Problemas.

Professor: Entendo... e porque você acha que isso é um problema?

TLL: Porque é trabalho desnecessário...

(TLL, TAC-GX-E8, EF ; RPG, TAC-GZ-E8)

Os membros do grupo Z, movidos pelo mesmo desconforto, optaram por criar um novo "tipo" de Problema, que pudesse abranger aqueles que, em seu entendimento, não poderiam ser classificados pelos tipos anteriores, mas a consequência foi de que o novo "tipo" também poderia ser aplicado a muitos outros Problemas, exatamente como os já propostos inicialmente. Essa conclusão se verifica, por exemplo, quando o professor 
questiona se os licenciandos do grupo $Z$ "criaram esse novo tipo para usar nessas questões [sem resposta]" (Professor, TAI-E8, EF) e é respondido por RPG que "sim... também", mas que acabaram usando "em outras questões também... que têm resposta, mas que pode ser resolvido só com lógica". Ou seja, a solução sugerida para minimizar o desconforto inicial sobre a mera criação de "tipos" para classificar os Problemas, por sua subjetividade e falta de função na organização do ensino, não alcançou este objetivo, pois, a partir da intervenção de TLL, o problema não seria a existência de Problemas que não poderiam ser tipificados pelos critérios estabelecidos, mas sim que a subjetividade da proposta fazia com que atribuir a um Problema "todos os tipos" ou "tipo nenhum" teria resultados idênticos na prática docente, o que, ao que tudo indica, o levou a compreender a tarefa como "trabalho desnecessário".

Importante destacar a indicação de TLL de que "raciocínio lógico também se aplica a todos os Problemas daqui [da folha de registro]... e esse é o problema" (TLL, TAC-GX$E 8, E F$ ), pois ele identifica um problema na situação de aprendizagem da docência em que está envolvido, que seria o fato de que aquela forma de organizar os Problemas (por tipos) não contribuiria para seu objetivo (planejar uma aula) de modo que ele se colocou em um movimento em busca da solução para seu próprio problema, e encontrou uma possibilidade de resposta a partir da provocação do professor.

TLL: [...] a gente podia só escolher um Problema e fazer o plano de aula direto... e se quiséssemos só aplicar alguma coisa, a gente pegava um Problema assim... Professor: E se não tivesse nenhum que te atendesse?

TLL: A gente mudava ele [o Problema] pra servir...

(TLL, TAC-GX-E8, EF)

O licenciando entende que seria "mais proveitoso" analisar os Problemas unicamente para atender ao propósito de planejar a aula, sem necessidade de saber quais aspectos estariam envolvidos na solução, se aplicação de um conceito, se o "treino" de um algoritmo, se aplicação de técnicas heurísticas, etc. A análise parece colocar em tela novamente a questão do objetivo do professor e sua intencionalidade ao propor um Problema, de modo que os aspectos da solução são decorrentes das necessidades de apropriação conceitual pelos sujeitos envolvidos na solução. As técnicas de solução, em si, não seriam premissa para seleção do Problema. Questionado pelo professor sobre sua estratégia caso nenhum dos Problemas contidos na relação atendesse seus 
interesses para o planejamento, a resposta do licenciando ratifica essa constatação: "A gente mudava ele [o Problema] pra servir" (TLL, TAC-GX-EF, EF).

A disposição para alterar o Problema de modo a que este passe a "servir" aos objetivos do professor vai ao encontro da compreensão que defendemos de que o Problema deve estar impregnado da necessidade de apropriação conceitual que possa desencadear a aprendizagem, no contexto de uma SDA. O Problema proposto como exercício de técnicas de resolução traz à tona o conflito, a contradição, que conduz ao questionamento "qual a razão disso?". Nesse contexto, a tipificação de Problemas, conforme indicam nossos dados, parecem remeter a aspectos esperados na resolução que não têm, necessariamente, relação com a apropriação conceitual que pretende o professor ao propor um Problema. Por isso esse aspecto é relevante para nós, sem que isso caracterize algum demérito a tal tipificação em outros contextos que, eventualmente, fujam ao nosso foco de análise.

Já no encontro posterior, o nono do experimento formativo, foi solicitado aos licenciandos que dispusessem de livros didáticos disponíveis na sala ${ }^{26}$ em que a formação estava sendo realizada, para selecionar neles algum Problema que pudesse ser utilizado na regência de estágio. $O$ movimento do grupo $X$, especialmente do licenciando TLL, chamou novamente nossa atenção, durante a socialização das discussões de cada grupo, em que os licenciandos discutiam aspectos da utilização do seguinte Problema encontrado em um dos livros didáticos:

\footnotetext{
${ }^{26}$ A sala em questão abrigava o espaço coletivo que era denominado como "Laboratório de matemática", em que ficavam disponíveis aos estudantes, além de espaço de estudo e computadores, material de apoio como alguns jogos, livros didáticos da educação básica e livros referentes ao conteúdo matemático e pedagógico da educação superior.
} 
Figura 13: Problema extraído livro didático grupo $\mathrm{X}^{27}$
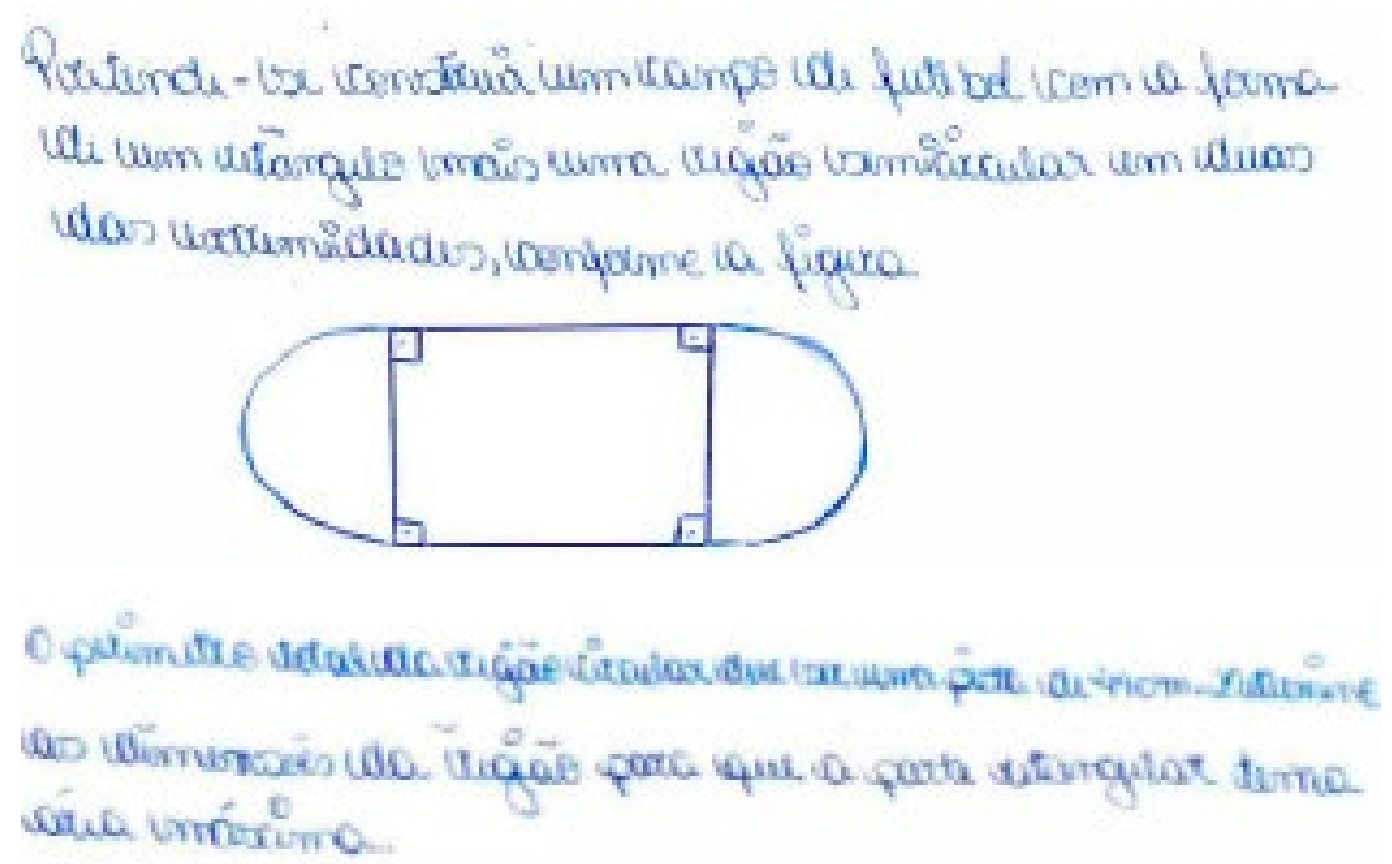

Fonte: Adaptado pelos integrantes do grupo X do livro didático "Smole, K. S.; Diniz, M. I. matemática: ensino médio. Volume 3. $3^{a}$ série $-3^{a}$ ed. reformulada. São Paulo: Saraiva, 2003. p. 303

Na apresentação de sua opção, TLL indica o que segue:

TLL: Eu escolhi esse Problema aqui [referindo-se ao Problema do livro]... pra falar de máximo da função... mas fiz uma "adaptaçãozinha"... porque acho que o Problema dá margem pra duas interpretações... aqui ó [indicando no livro] fala que a região é o semicírculo, e que a região é [tem perímetro igual a] 440 metros... eu acho que esses 440 é de cada semicírculo, mas o PTO (outro integrante do mesmo grupo) entendeu que é 440 as duas partes... que seria o círculo...

Professor: Tá... e essa adaptação foi o que?

TLL: Eu mudei pra ficar mais claro... coloquei que o perímetro total da região circular é que vale 440 metros.

Professor: E isso é importante porque?

TLL: Porque o Problema teria duas soluções possíveis... uma com 440 de perímetro em tudo e outra que o perímetro ia ser 880 , que é 440 daqui [referindose a um dos semicírculos] e outro daqui [indicando o outro semicírculo].

Professor: Ok... mas com qualquer dos valores, não daria pra você trabalhar a ideia de máximo da função?

TLL: Daria...

PTO: (interrompendo) mais ou menos, professor... porque aqui [no livro] é colocado como se fosse pra resolver com [aplicando-se o conceito de] derivada... mas dá pra fazer sem isso aí também...

27 Transcrição do enunciado original: Pretende-se construir um campo de futebol com a forma de um retângulo mais uma região semicircular em duas extremidades, conforme a figura. [figura reproduzida pelo aluno]. O perímetro da região deve ser uma pista de $440 \mathrm{~m}$. Determine as dimensões da região para que a parte retangular tenha área máxima. 


\section{Professor: Como?}

PTO: Quando você resolve, você "cai" numa equação de segundo grau... aí não precisa derivar se não quiser... você consegue resolver com [aplicando-se a fórmula conhecida como sendo de] Bháskara...

(TLL e PTO, TAI-E9, EF)

TLL parece indicar que a solução para o Problema deve ser única, de modo que seria inadequado que o Problema mantivesse a dubiedade que reconheceu no enunciado original. Entendemos que, de fato, o Problema selecionado tem potencial para suscitar, de alguma forma, a necessidade de compreensão do conceito que pretendia ensinar (máximo de uma função). Ainda assim, o estudante preocupou-se em verificar se o Problema precisaria de algum tipo de "ajuste" para que estivesse de acordo com seus objetivos. Entendemos também que a adaptação realizada pelo licenciando não alterou a necessidade de apropriação conceitual que já estava presente e que, ao que parece, motivou que o licenciando o escolhesse para subsidiar sua proposta de aula.

Buscamos analisar, ainda, a proposta das autoras do livro didático de onde o licenciando extraiu a proposta. Na unidade do referido livro, as autoras tratam da "taxa de variação média", a partir de uma questão sobre o crescimento médio de um personagem, conhecidas suas alturas entre os anos de 1997 e 2003. As autoras indicam que "essa não é uma questão difícil de responder" (SMOLE e DINIZ, 2003, p. 277) tratam de apresentar a solução, seguida da definição de "taxa de variação média", a ideia de variação vai, então, sendo explorada em situações modelares (que servem como modelos) até a apresentação da definição de derivada. O Problema escolhido por TLL, compõe uma relação com oito questões na seção "Problemas e exercícios" da unidade 11 do referido livro. Todos as questões pressupõem a aplicação do conceito de derivada para o cálculo dos pontos de máximo ou mínimo de funções dadas, sendo que, ao que parece, as duas últimas questões são os "Problemas", pois são questões de aplicação envolvidas em um contexto "real". Dessas duas, a última questão é indicada como um item de avaliação em vestibular da UNICAMP.

TLL, no entanto, elege o Problema não como recurso para aplicação do conceito, mas como elemento com potencial para suscitar a necessidade de apropriação que tem como objetivo. Ao ser questionado se considerava o Problema adequado ao seu propósito o licenciando responde afirmativamente justificando que "o aluno vai entender a ideia de 
ponto máximo de uma função [polinomial] do segundo grau... [e] essa é a ideia" (TLL, TAlE9, EF).

PTO, por sua vez, parece entender que o Problema não traria a necessidade de reflexão sobre a ideia de "máximo da função" que seria o objetivo. Ao que parece, ele compreende o Problema dentro do contexto em que é apresentado no livro, ou seja, como aplicação de técnicas de derivação para se encontrar a solução, e, reconhecendo a possibilidade de se resolver o Problema sem precisar derivar, ele passa a entender que o Problema não traria a necessidade de pensar sobre o conceito, já que pode ser resolvido de outra forma. Por esse raciocínio, porém, PTO não estava, tudo indica, pensando na ideia de máximo da função que TLL anunciou que pretendia ensinar, mas sim na técnica de solução (a derivada). Nesse contexto o professor sugere uma reflexão.

Professor: Mas [resolver usando a fórmula de Bháskara] é a mesma ideia de máximo e mínimo, não é?

PTO: Sim... mas não precisa saber derivada...

Professor: O TLL disse que o objetivo era trabalhar a ideia de máximo da função, certo?

Alguns alunos em uníssono: Certo...

Professor: Então, tirando o problema de escrita que o TLL corrigiu, o Problema dá pra trabalhar esse conceito?

TLL: Dá... o aluno vai entender a ideia de ponto máximo de uma função [polinomial] do segundo grau... essa é a ideia... se vai derivar ou não é outra história.

(TLL e PTO, TAI-E9, EF)

Lembramos que, inicialmente, TLL indicava que os Problemas deviam ser selecionados de instrumentos diversos de acordo com o conteúdo que o aluno devia aprender. O propósito dessa seleção seria ampliar o repertório de Problemas conhecidos pelo professor e potencializar que este conhecesse situações que pudessem ser apresentadas aos alunos para aplicar os conceitos que estivessem em estudo.

Entendemos que TLL apresenta indícios de que a proposição de Problemas tal e qual aparecem no livro didático vai deixando de ser compreendida por ele como ideal e o próprio livro vai deixando de ser compreendido como "receita", a ser seguida dogmaticamente, e passa a ser compreendida como recurso didático e de mediação cultural que pode aproximar da realidade do aluno aspectos diversos da produção humana. A proposição de TLL sugere que o livro seja fonte de Problemas, inclusive aqueles que já foram objeto de avaliação em eventos como os vestibulares, mas que possam subsidiar uma organização da prática docente independente da sequência e da abordagem 
metodológica sugerida no próprio livro ou da mera aplicação daquilo que foi "explicado" anteriormente.

Esse movimento de TLL parece convergir para o reconhecimento da importância da intencionalidade que deve permear a organização das atividades docentes, em consonância com a Teoria da Atividade de Leontiev. O licenciando indica que, mais importante do que atribuir "tipos" genéricos aos Problemas ou se limitar à aplicabilidade de técnicas específicas apresentadas no livro didático, os objetivos do professor devem protagonizar a organização do ensino. Ao reconhecer, por exemplo, o objetivo do professor como sendo ensinar os conceitos de máximo e mínimo da função e não, necessariamente, aplicar técnicas de derivação, ele indica que "o aluno vai entender a ideia de ponto máximo de uma função [polinomial] do segundo grau... essa é a ideia... se vai derivar ou não é outra história" (TLL, TAI-E9, EF). Em outras palavras, aqui TLL dá indícios de um reconhecimento de que o sentido não seria decorrente do Problema em si, mas sim do conjunto formado pela necessidade que o Problema pode suscitar, da intenção do professor e da maneira como este organiza o ensino, superando, talvez, uma compreensão inicial que remeteria apenas a conhecer e selecionar um grande repertório de Problemas prontos sobre diversos temas específicos para apresentar posteriormente aos alunos.

Ao mesmo tempo, os Problemas "prontos" apresentados nos recursos didáticos escolhidos pelos licenciandos, especialmente ISC, DFS, RPG e, principalmente, TLL, seja na lista com Problemas a serem tipificados ou na busca por Problemas nos livros didáticos, parecem estar em contradição com um movimento de apropriação do conceito de Problema em que este deve suscitar a necessidade de apropriação do conceito que se deseja ensinar e em relação dialética com os objetivos de ensino do professor e, por consequência, com sua intencionalidade. Moura, et al. (2017) destaca que a palavra "orientadora" presente no conceito da AOE coloca em evidência, justamente, o aspecto intencional de quem ensina. Nesse contexto, compreendemos que há indícios de constituição de novos sentidos que indicam a superação da apresentação de Problemas "prontos", em listas que remetem à aplicação de algo que já foi apresentado, aproximam os licenciandos do significado social de Problema produzido no contexto da THC e potencializa que os licenciandos, ao destacar a própria intencionalidade e seus motivos, 
entrem em atividade de ensino e possibilitem que seus alunos entrem em atividade de aprendizagem.

\subsubsection{Síntese do isolado A}

A partir da compreensão de superação que é própria do materialismo históricodialético e, consequentemente, da THC, este isolado mostrou indícios de um movimento dos sentidos dos licenciandos que remetem às apropriações sobre a importância da intencionalidade e dos motivos que colocam o professor em atividade de ensino. Esse movimento indica o reconhecimento do que identificamos como protagonismo do Problema no contexto da SDA.

No contexto das situações desencadeadoras de aprendizagem da docência que propusemos aos licenciandos pudemos identificar e acompanhar um movimento de alteração dos sentidos pessoais que, assim como indica Leontiev (1978), se relaciona com as alterações de motivos que colocam o sujeito em atividade. Ao se depararem com a necessidade de planejar uma aula em que o conteúdo devia ser ensinado a partir de um Problema, os sentidos pessoais de alguns licenciandos que remetiam à aplicação de lições previamente ensinadas estavam relacionados a motivos para propor situações que reproduziriam um percurso que parte de uma definição matemática lógico-formal, passa pela apresentação de propriedades e algoritmos ou pela revisão de pré-requisitos (como as porcentagens para o ensino de juros simples, como indicaram as licenciadas do grupo Z) para a posterior proposição de situações que remeteriam à mera aplicação do que fora apresentado antes.

O contexto da atividade que destacamos nesse isolado, no entanto, indica um movimento desses sentidos pessoais iniciais que remete ao reconhecimento de que a proposta de ensinar conceitos matemáticos a partir de Problemas acarreta a necessidade de que estes Problemas suscitem a necessidade de apropriação do conceito pelos sujeitos e que a mera proposição de Problemas "prontos", selecionados a partir de recursos didáticos diversos, apenas potencializa a aplicabilidade e não consideraria aspectos relacionados à intencionalidade e aos motivos do próprio professor. Assim, o Problema assumiria o protagonismo da atividade de ensino no contexto da AOE, pois é o Problema que indica a intenção do professor e caracteriza a necessidade que ensejará motivos para 
colocar o estudante em atividade de aprendizagem. É também no Problema que se evidenciam os motivos do professor. Dessa forma, o Problema pode ser compreendido como protagonista da AOE e constitui a essência da Situação Desencadeadora de Aprendizagem.

A figura 14, a nosso juízo, sintetiza o movimento geral que pudemos observar nesse primeiro isolado. 
Figura 14: Síntese do isolado A

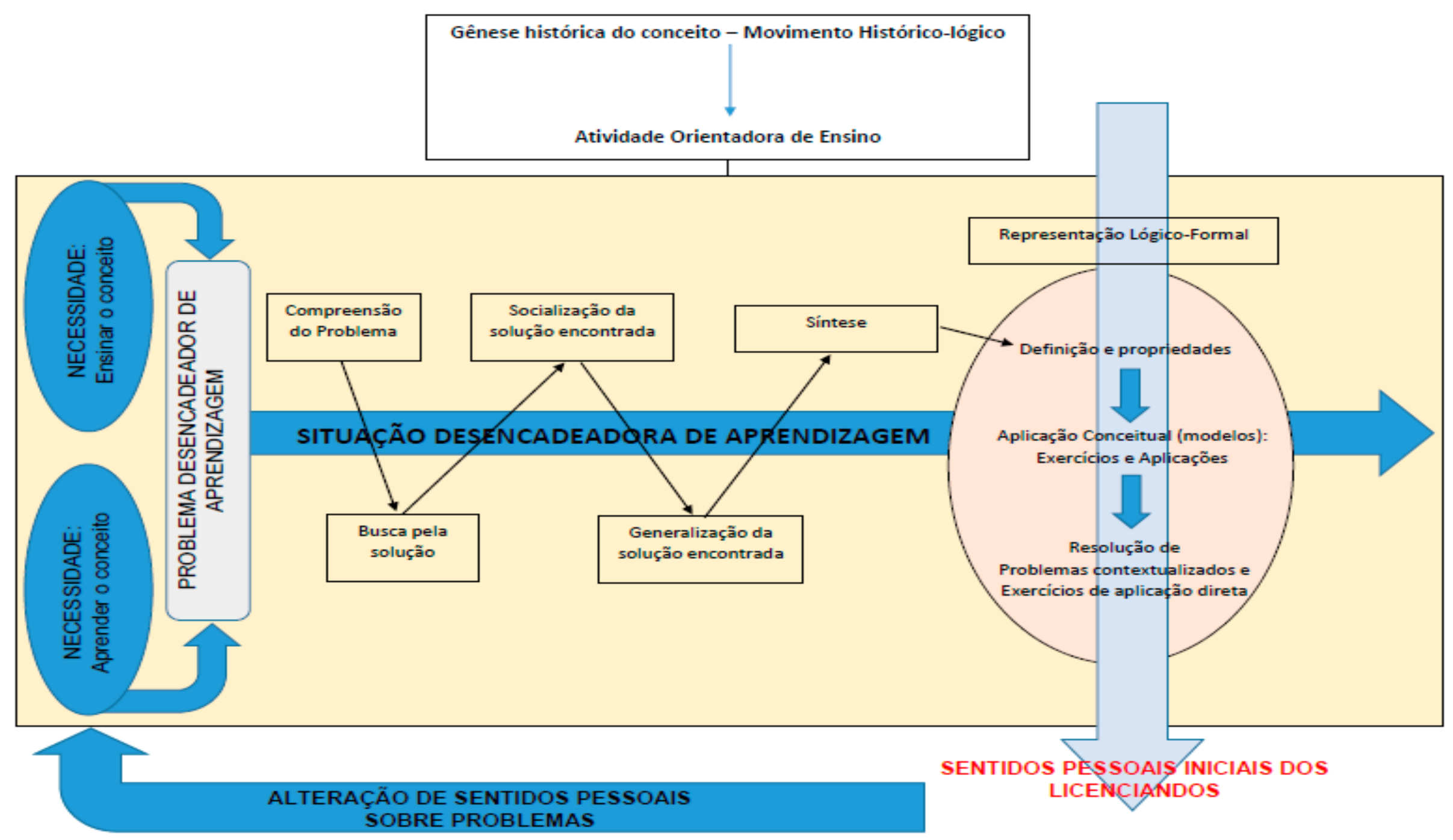

Fonte: Elaborada pelo autor 
A figura 14 remete ao movimento dos sentidos no contexto da $A O E$, em que verificamos indícios de que os sentidos pessoais iniciais dos licenciandos, que compreendiam que o papel do Problema em suas práticas pedagógicas como recurso de aplicação de aspectos lógico-formais do conceito, são superados por uma compreensão histórico-lógica que evidencia o reconhecimento de que o Problema suscita a necessidade de apropriação do conceito pelo estudante, bem como explicita a intencionalidade e os motivos do professor na atividade de ensino. Nesse contexto, os aspectos lógico-formais não são desconsiderados, mas passam a integrar uma apropriação teórica do conceito em um perspectiva histórico-lógica, em que a AOE representa a unidade entre a atividade de ensino e a atividade de aprendizagem.

Em síntese, o isolado A permitiu reconhecer indícios de um movimento dos sentidos pessoais dos licenciandos que remetem à superação das compreensões sobre o papel do Problema na organização do ensino, passando de recurso de aplicação de definições e propriedades já ensinadas para aproximar-se de um significado social de Problema, compreendido no contexto da THC como elemento desencadeador de aprendizagem a partir da potencialidade de suscitar necessidades de apropriação conceitual que, por sua vez, se assemelham àquelas que, na história e na cultura humana, culminaram na produção dos conceitos em estudo. Essa característica, a nosso entender, com base na fundamentação teórica e metodológica que adotamos, deve permear o movimento formativo de professores a fim de que estes possam elaborar ou reelaborar Problemas com potencial para suscitar as referidas necessidades e desencadear a aprendizagem, evidenciando a intencionalidade e os motivos do professor na atividade de ensino, no contexto das SDA e organizados segundo os preceitos das AOE.

\subsection{O papel dos estudos de História da matemática na organização da atividade pedagógica}

Considerando a origem marxista da fundamentação metodológica desta pesquisa, compreendemos que é por meio do trabalho que o homem se humaniza em um movimento que é histórico e cultural. Assim, adotamos como premissa que os processos de ensino e de aprendizagem devem considerar a cultura e a história humana para 
suscitar, no contexto ontogenético, as necessidades que levaram a humanidade, filogeneticamente, a produzir o conhecimento por ela acumulado, de modo que cada sujeito possa superar a mera adaptação à natureza à sua volta para modificá-la ao mesmo tempo em que é modificado por ela. É a partir dessa premissa que destacamos o nosso isolado $B$ que pode ser compreendido como o movimento dos sentidos sobre o papel dos estudos de História da matemática - HM na aprendizagem da organização da atividade pedagógica voltada ao ensino de matemática e na proposição de Problemas com potencial para desencadear as atividades de ensino e de aprendizagem.

Como vimos, no item 1.2, diretrizes oficiais dos cursos de licenciatura colocam os estudos de HM como componente obrigatório das matrizes curriculares. A HM também tem encontrado defensores de seu ensino como aspecto do conhecimento escolar, de modo que o professor estudaria a $\mathrm{HM}$ factual, ou seja, como ela teria acontecido segundo documentos e estudos históricos, para poder "contar" aos seus alunos como a matemática se desenvolveu ao longo dos anos, a fim de que estes últimos possam estabelecer comparações entre aspectos da matemática atual com aspectos de outros tempos.

É esse o contexto que coloca em destaque mais um isolado de nosso experimento formativo. Considerando que os sete licenciandos, cujo movimento destacamos na pesquisa, já haviam concluído com aproveitamento considerado satisfatório na disciplina de História da Matemática da matriz curricular do curso, todos possuíam sentidos pessoais iniciais sobre o papel da HM nas práticas docentes que já estavam relacionados de alguma forma à formação oferecida pelo curso. Verificamos que, de fato, os sentidos iniciais dos licenciandos parecem convergir para a compreensão de que a HM permitiria tecer comparações entre os modos de fazer do presente e os do passado.

O isolado é composto pelo episódio B1 intitulado "suscitando historicamente a essência da necessidade do conceito" e emerge dos encontros E4, E5 e E6 do experimento formativo, nos quais foram discutidos aspectos da preparação de uma aula sobre o conceito de logaritmos a uma turma fictícia de Ensino Médio. 


\subsubsection{Episódio B1: Suscitando historicamente a essência da necessidade do conceito.}

Ainda durante o primeiro semestre, que já apresentamos no subitem 3.1.1 e no subcapítulo 4.1, realizamos estudos afim de reconhecer aspectos da compreensão dos licenciandos sobre a importância da HM para a elaboração de Problemas voltados ao ensino de conceitos. Naquele contexto, a partir de um texto adaptado, baseado nos trabalhos de Eves (2011), Boyer (1974) e Roque (2012), foram estudados aspectos da história do conceito de equações. Ao final daquele primeiro semestre, dois licenciandos, dentre os sete que destacamos nesta pesquisa, indicaram em seus relatórios que propuseram a seus alunos, na regência de estágio supervisionado, situações que eles próprios classificaram como "desencadeadoras", a partir de Problemas que consideravam aspectos históricos do conceito que pretendiam ensinar.

Estes licenciandos, ISC e MGO, quando questionados inicialmente sobre qual seria a importância de se estudar HM no curso de licenciatura em matemática, indicaram que seria para "mostrar como os matemáticos de antigamente usavam a matemática no dia-a-dia e [para] poder aprender as coisas que eles descobriram" (ISC, TAI-E6, PEF) e para "conhecer como os conteúdos foram criados e para introduzir os conteúdos e mostrar as aplicações" (MGO, TAI-E6, PEF).

Situamos esse episódio B1, precisamente, nos dados coletados a partir do debate suscitado dos estudos sobre o conceito de Logaritmos e do movimento dos sentidos pessoais de ISC e MGO nesse contexto.

Os licenciandos realizaram estudos a respeito da história do conceito de logaritmos e apresentaram considerações pessoais espontâneas, de onde pudemos reconhecer aspectos de sentidos pessoais iniciais sobre o papel da HM nas práticas pedagógicas (E4), depois (E5) eles foram convidados a discutir uma SDA que propunha um PDA que remetia ao cálculo de logaritmos não inteiros (Log2 e Log3). Denominamos essa SDA como "O Problema de João Napião" e a mesma está apresentada no Apêndice 1. Foram, então, realizadas as discussões e a síntese da proposta (E5 e E6). Os dados coletados nesse contexto, estão apresentados a seguir.

Os licenciandos realizaram os estudos da história do conceito a partir de texto, também adaptado por nós a exemplo do que já havíamos feito no primeiro semestre, e 
depois foram convidados a discutir aspectos relacionados ao Problema, à solução e as relações entre estes e a história do conceito que havíamos estudado.

Antes, porém, havíamos realizado uma discussão sobre aspectos considerados tradicionais verificados no ensino dos Logaritmos.

Professor: [Enquanto falavam os licenciandos do grupo $\mathrm{X}$ ] quero perguntar uma coisa: como foi que os professores de vocês, lá no Ensino Médio ou na faculdade mesmo ${ }^{28}$, ensinaram Logaritmos para vocês?

MGO: Olha, professor, é bem complicado [risos]... eu fiz com [...]

Professor: [Interrompendo] Não precisa citar os nomes.

MGO: Ah, tá... então foi difícil... porque tinha muita lista para fazer... e eu não tinha tempo... passei de raspão... [risos]

Professor: Certo... entendo... e antes? Você não tinha estudado antes?

MGO: Tinha, professor... mas daquele jeito, né?... juntando que era em escola pública e que eu era molecão... [risos] não aprendi nada.

Professor: [risos] Entendo... Mas como foi ensinado pra vocês... tirando essa parte que tinha muitas listas de exercícios, o que mais?

MGO: Ah... a [esquecendo-se do pedido e citando o nome da professora] ensinava bem... é porque o assunto é difícil mesmo... tive que estudar mais pra passar. Mas eu aprendi, no final... pelo menos o suficiente para passar.

Professor: Entendo... e os demais?

[Após falas de outros licenciandos]

PNL (do grupo Y): Eu também achei difícil, professor... sempre me confundia... no fim eu tive que decorar para fazer as listas [de exercícios] e a prova...

Professor: Decorar o que?

PNL: O jeito de fazer... que pega o de baixo e tem que elevar à resposta para achar o outro... e também tive eu decorar as propriedades. A prova foi todinha sobre as propriedades.

(MGO, TAI-E4, EF ; PNL, TAI-E4, EF)

Verificamos que a proposição de que os licenciandos estudassem aspectos relacionados ao conceito de Logaritmos durante a graduação (em disciplina específica para esse fim, no caso do IFSP) se justificava, pois o próprio conceito não havia sido apropriado pelos licenciandos durante a educação básica, como podemos inferir a partir da consideração de MGO de que, por várias circunstâncias, não havia aprendido - "era em escola pública e eu era molecão... não aprendi nada" (MGO, TAI-E4, EF). No entanto, foi premente que, mesmo sendo uma estratégia voltada à busca pela superação de uma defasagem de aprendizagem em relação ao currículo do Ensino Médio, na graduação os licenciandos, mesmo tendo sido aprovados na disciplina, não se apropriaram do conceito, mas, ao contrário, lançaram mão de técnicas, relacionadas à memorização, para obterem aprovação.

\footnotetext{
${ }^{28}$ Havia uma disciplina na matriz curricular que tinha como objetivo ensinar Logaritmos.
} 
A partir da fala de PNL, inferimos que ela teve que "decorar" técnicas que estariam sendo, ao que parece, apresentadas e que remetiam à definição lógico-formal de logaritmos. Compreendendo o logaritmo a partir de uma definição que aponta que o logaritmo é o expoente de uma potenciação em que são conhecidas a base e a potência (o "resultado") é comum que o professor mostre aos alunos que, para calcular logaritmos ele deve encontrar o expoente da potência que tem a base do logaritmo como sua própria base e o logaritmando como potência. Dessa forma, por exemplo, para resolver o caso específico $\log _{2} 16=x$, em que $\mathrm{x}$ é o logaritmo, o professor indicaria que esse $\mathrm{x}$ é o que chamamos de logaritmo e que, para encontrá-lo, o aluno deve encontrar o expoente da potenciação que tem base 2 e cuja potência é 16. Para conduzir essa maneira de pensar o professor perguntaria algo como: "dois elevando a quanto dá 16?". E a resposta, muitas vezes dada pelo próprio professor, (nesse caso, "quatro") é apresentada como sendo o logaritmo. O professor, então, resumiria a estratégia de cálculo dizendo "esse [apontando $\circ$ 2] elevado a esse [apontando o $x$ ] é igual àquele [apontando o 16]", como dito pela licencianda. Ela também indica que teve "que decorar" as propriedades dos logaritmos e que a prova havia sido fundamentada na aplicação dessas propriedades, o que constitui um indício de que sua apropriação (fruto de um processo de memorização mecânica, baseada na aparência) estaria voltada para a aplicação em situações específicas, sem reconhecer, portanto, um contexto geral que inclui o próprio conceito.

A SDA "O Problema de João Napião" foi, então, apresentada aos licenciandos e o movimento de busca pela solução foi acompanhado pelo professor. Foi feita a resolução da situação e foi discutido o aspecto da necessidade suscitada pelo PDA que leva à reflexão sobre o conceito, bem como sobre a potencialidade da SDA para o ensino em comparação com as proposições tradicionais para o ensino dos Logaritmos que haviam sido levantadas naquele encontro anterior. $\mathrm{Na}$ discussão sobre esses aspectos $\mathrm{O}$ professor pergunta aos integrantes do grupo $\mathrm{X}$ :

Professor: E vocês acham que um Problema como esse poderia ser utilizado na aula de matemática?

PTO (integrante do grupo, não analisado): Sim, acho que sim.

MGO: Eu nunca parei pra pensar que as propriedades dos logaritmos "vêm" das propriedades das potências. Mas se você parar pra pensar faz todo o sentido.

PTO: Faz... é porque assim a gente consegue explicar porque vale cada propriedade. 
Professor: Você acha que os alunos precisariam que explicasse as propriedades dos log pra eles antes? Eles não conseguiriam resolver sem falar sobre isso?

(MGO, TAC-E5-GX, EF ; PTO, TAC-E5-GX, EF)

A provocação do professor vai ao encontro da desconstrução do sentido inicial recorrente segundo o qual os alunos deveriam resolver Problemas a partir de definições e propriedades previamente apresentadas. PTO parece ter admitido, a priori, que o Problema de João Napião deveria ser apresentado aos alunos após estes conhecerem a definição e as propriedades de logaritmos (já que ele próprio já o conhecia e, por isso, não teve muita dificuldade em encontrar soluções para o Problema junto com seu grupo). Sua consideração parece indicar que o Problema serviria como uma espécie de caminho para a "demonstração" das propriedades. Por essa razão ele teria concluído que o Problema possibilitaria "explicar porque vale cada propriedade" (PTO, TAC-E5-GX, EF). A essa provocação do professor, ISC responde, após alguns instantes de hesitação dos colegas de grupo:

ISC: conseguiriam... acho que conseguiriam... porque não é sobre propriedades de log... o Problema não precisa dessas propriedades... precisa das propriedades das potências. No ensino médio [público alvo apontado na proposta] eles já sabem isso... acho que eles fariam e só depois podíamos mostrar que é a mesma coisa. (ISC, TAI-E5, EF)

A resposta de ISC pode ser considerada indício de uma compreensão segundo a qual o Problema, de fato, suscita uma necessidade essencial para o desenvolvimento do conceito de logaritmos, além de indicar, no contexto de seu próprio movimento formativo, como um todo, um reconhecimento de que o Problema, na perspectiva que vínhamos trabalhando, suscita uma necessidade sobre um conceito novo, e não uma aplicação de algo já ensinado.

No caso específico a compreensão de que conversão de uma multiplicação em uma adição suscita a necessidade de se encontrar meios para relacionar potências e bases conhecidas em busca de expoentes que serão adicionados. Tal necessidade coloca em segundo plano as propriedades do conceito central, sendo uma consequência do movimento de aprendizagem e não mais uma premissa. Essa característica se relaciona com o fato de que, na história factual do conceito, as propriedades decorrem do movimento de constituição histórica que culmina na sua compreensão lógico-formal. Em outras palavras, os logaritmos não existem a priori, para terem definição e 
propriedades, desde sempre. No processo de aprendizagem desse conceito, da mesma forma, o estudante não tem apropriado ainda o conceito, de modo que não pode aplicar definições e propriedades daquilo que ainda não conhece.

Essa relação entre o Problema proposto e a HM é objeto do questionamento do professor, um pouco mais adiante:

Professor: Certo... e o que vocês acham desse Problema e da história dos logaritmos que falamos na semana passada?

ISC: Então, professor... se for parar pra pensar, é a mesma coisa... porque a história é a mesma que o "carinha lá" [provável referência a Jonh Napier] queria fazer, que era transformar a multiplicação na adição porque era mais fácil fazer adição do que fazer multiplicação...

Professor: Ah, legal... e no que que isso ajuda?

ISC: Eu fiz assim no meu estágio no semestre passado. Eu fiz que nem na história mesmo. E os alunos gostaram bastante.

Professor: Como que você fez [no semestre anterior, durante a regência]?

ISC: Bem, eu falei sobre frações... contei a história lá das cheias do Nilo e dividimos a sala em algumas áreas que deveriam ser divididas por causa da cheia do rio... daí os alunos escolheram uma unidade de medida que foi o pé de um deles mesmo... daí eles perceberam que não dava pra medir exatamente todas as medidas que precisavam... então eu ajudei eles a encontrar as subdivisões que ajudava a medir...

Professor: (interrompendo) e você fez assim porquê?

ISC: Porque assim eles entenderam mais fácil porque que a medida tem que ser igual [frações "reduzidas" ao mesmo denominador] e as divisões [da unidade] para formar as partes.

Professor: E no caso dos logaritmos agora, você entende que fizemos algo parecido?

ISC: Sim... a mesma coisa... a história mostra como foi feito lá [no passado] e nós podemos usar isso pra ensinar aqui [no presente].

Professor: Ah, legal essa ideia... de usar a história pra ensinar hoje... isso sempre é possível?

TLL: [após alguns segundos de hesitação, novamente] acho que depende... da turma e da matéria... tem turma que não dá pra ficar contando história... porque eles dispersam... então tem que dar logo coisa pra eles fazerem... [risos]

Professor: Mas precisa contar a história?

TLL: Acho que sim...

MGO: [discordando do colega de grupo] acho que não... que nem esse aí... do log... se não contar a história o aluno consegue resolver do mesmo jeito e vai entender o que é logaritmo mesmo se o professor não falar... pode ser que ele não chame de logaritmo sozinho... mas vai entender a ideia.

(ISC, MGO e TLL, TAC-E5-GX, EF)

O questionamento do professor conduz a aspectos que, até aquele momento, não haviam sido explicitados no debate e faz com que ISC estabeleça comparação entre a proposta desenvolvida durante sua própria regência de estágio, que já apresentamos anteriormente, e a proposta em discussão. O licenciando reconhece como essencial em ambas as propostas (a referente aos logaritmos e sua própria) o fato de remeterem a 
colocar os alunos diante de necessidades que simulam (ou reproduzem) as necessidades impregnadas no contexto histórico que dá origem ao conceito. Esse aspecto vai ao encontro dos estudos de HM que defendemos, no contexto da AOE, conforme Moura et al. (2011). ISC indicia reconhecer que o Problema de João Napião se relaciona com a história factual, ainda que não o reproduza textualmente. Ao dizer que "se for parar pra pensar, é a mesma coisa... porque a história é a mesma que o "carinha lá" (ISC, TACE5-GX, EF), numa provável alusão a John Napier, o licenciando indica que reconhece na história virtual a essência do conceito desenvolvido na história factual e que isso é necessário e suficiente para que compreendamos "como foi feito lá [no passado] e nós podemos usar isso pra ensinar aqui [no presente]" (ISC, TAC-E5-GX, EF).

Por fim, após o professor estender aos outros grupos o questionamento sobre as relações percebidas entre o processo de resolução do Problema proposto e a história do conceito, foi possível registrar a seguinte conversa das integrantes do grupo Y:

JZM: Nós aqui [no grupo Y] não tínhamos falado sobre isso [relações entre a história do conceito e o Problema resolvido], mas ouvindo eles ali [referência ao grupo X] acho que é certo mesmo...

Professor: Como assim?

JZM: É certo mesmo, professor, esse olhar para a história... porque assim o professor pode fazer como você falou e apresentar os Problemas para o aluno resolver e aprender fazendo... entende?

Professor: Acho que entendo [risos]...

PNL: [entre risos] É que o Problema é igual à situação da história, como eles [grupo X] disseram... então é como se o aluno tivesse inventando os logaritmos na história... e se o professor ajudar eles [os alunos] conseguem aprender log sem ter que ficar fazendo aquele monte de exercício de esse elevado a esse é igual àquele...

(JZM e PNL, TAC-E5-GY, EF)

Ainda que ligeiramente confusa em sua construção, a consideração de JZM parece indicar uma compreensão de que o Problema seria desencadeador de aprendizagem. Ao registrar que o professor pode "apresentar os Problemas para o aluno resolver e aprender fazendo" (JZM, TAC-E5-GY, EF) a licencianda apresenta um indício de que o processo de resolução do Problema é pressuposto para a aprendizagem. Entendemos que, compreendido dessa forma, o Problema assume o papel de desencadeador de aprendizagem e se caracteriza como essência da Situação Desencadeadora de Aprendizagem, potencializando a possibilidade de que os sujeitos envolvidos entrem em atividade, em consonância ainda com os fundamentos teóricos sustentados em Moura et al. (2011), Moura et al. (2018) e Araújo (2018). E, na 
compreensão de JZM, o aspecto que possibilitaria a conclusão de que o Problema seria desencadeador de aprendizagem é o "olhar para a história" (JZM, TAC-E5-GY, EF). O indício de uma apropriação desse significado histórico-cultural de Problema, compreendido como desencadeador de aprendizagem, se materializa também na intervenção de PNL que, em busca de auxiliar a colega na apresentação da discussão do grupo $Y$, afirma que "o Problema é igual à situação da história [...] é como se o aluno [es]tivesse inventando os logaritmos na história" (PNL, TAC-E5-GY, EF). A licencianda ratifica a compreensão de que o Problema é desencadeador de aprendizagem porque suscita necessidades históricas que simulam, numa história virtual, o processo de "invenção" dos logaritmos.

Quando PNL faz sua crítica à necessidade de "ficar fazendo aquele monte de exercício de esse elevado a esse é igual àquele" (PNL, TAC-E5-GY, EF), compreendemos que está fazendo referência àquilo que já tinha sido apresentado anteriormente em que, para a resolução de listas de exercícios, o aluno deve aplicar diretamente uma técnica a ser memorizada. Essa crítica remeteria, portanto a um movimento em relação ao sentido pessoal inicial dela de que os Problemas seriam mero recurso de aplicação de lições ensinadas previamente. Ao que parece, sua compreensão de que o Problema que suscita as necessidades históricas de produção do conceito superaria essa necessidade de aplicação mecânica da definição.

Entendemos também que a indicação de que "o Problema é igual à situação histórica" (PNL, TAC-E5-GY, EF) ratifica a compreensão de que a HM cumpriria o papel de indicar as necessidades inerentes ao processo criativo da humanidade (representado na fala da licencianda pelo verbo "inventar") de modo que a busca pela solução do Problema coincidiria com a busca pela satisfação da necessidade por ele suscitada, que, como entendemos, acontece no contexto das SDA estruturadas conforme os pressupostos da AOE. Dessa forma, o Problema não seria apenas aplicação de definições, mas sim desencadeador de aprendizagem.

A apresentação do grupo $Z$ aconteceu após os comentários do grupo $Y$ e as indicações de RPG e DFS, também parecem convergir para o entendimento de que os estudos de HM podem subsidiar a elaboração de Problemas que estejam impregnados das necessidades humanas que culminaram na produção do conceito: 
RPG: A gente acha que tem relação, também, professor... é que nem a [PNL] disse... é como se o aluno revivesse a história... se o professor ajudar ele vai entender que a ideia que ele usa na resposta é o logaritmo... a história do logaritmo serve numa aula que nem a história dos juros, lembra?... que estudamos a história e depois nós fizemos o Problema que fazia o aluno pensar igual aconteceu na história... ou pelo menos tentamos [risos]...

Professor: Verdade... e vocês tentaram e conseguiram...

LNS [outro integrante do grupo Z]: $E$ que depois sugeriram algumas mudanças, né?

Professor: Sim... mas as mudanças só foram possíveis porque vocês fizeram a proposta... vocês mesmo disseram na apresentação de vocês que tinham pensado na história dos juros pra fazer o Problema, certo?

DFS: Certo... [depois de alguns instantes] é que nós estudamos a história dos juros e fizemos a proposta de aula e, agora, você trouxe o Problema que também tem a ver com a história... a história é importante.

(DFS e RPG, TAC-E5-GZ, EF)

Ao citar aquilo que foi produzido em outro encontro (E2) e estabelecer comparação entre ambos, conferindo à HM a inter-relação entre ambas, DFS acaba conferindo à HM uma importância que ainda não havia atribuído. Por ocasião dos questionamentos sobre a importância de se estudar HM na licenciatura, ela afirmou que seria uma disciplina em que se poderia reconhecer personagens e fatos históricos relacionando-os a aspectos do desenvolvimento da humanidade (DFS, TAI-E6, PEF), mas, pelo que pudemos compreender na ocasião, como fins em si mesmos, ou seja, como objetos de um processo de contação de histórias. No desenvolvimento das atividades que trataram da HM conceitual sobre os conceitos de Juros e de Logaritmos, a indicação de DFS de que "a história é importante" (DFS, TAC-E5-GZ, EF) está embutida em uma compreensão de que as proposições que pautaram o planejamento de propostas de aula baseadas na proposição de Problemas, tiveram a HM como importante recurso, já que foi essa história que subsidiou a proposição dos Problemas. Diríamos que DFS não só reconheceu que a história é importante, mas atribuiu uma nova importância à essa história. Isso é indício de uma alteração de sentidos pessoais não apenas sobre o papel do Problema nas aulas, mas também sobre o papel da HM na proposição desses Problemas.

Mais adiante, no mesmo encontro 5, DFS ratifica essa nossa inferência:

DFS: A história da matemática, então, ajuda no planejamento [da aula]... legal isso... porque não é só para conhecer as pessoas que descobriram as coisas na matemática ou pra ver como eles fizeram...

Professor: Não... não só isso... eu diria que é para ver [dando ênfase ao termo] porque eles tiveram que fazer da forma como fizeram.

(DFS, TAC-E5-GZ, EF) 
Na continuação das considerações do grupo Z, RPG também apresenta uma posição que consideramos importante destacar:

RPG: sobre o que o senhor perguntou, se dá pra usar sempre... não sei se dá... porque também os alunos têm que saber resolver questões que não têm isso [a relação com a história].

Professor: Sim... claro... mas nessa proposta [Problema do João Napião], em que momento que o Problema é apresentado?

RPG: Como assim?

Professor: Em que momento da sua aula sobre logaritmos você apresentaria esse Problema para os alunos resolverem?

RPG: No começo... acho que no começo da aula...

[após outras falas]

RPG: Entendo... [é] como na história dos logaritmos... então não é igual [em sentido estrito] porque na história foi o [hesitando enquanto buscava o nome do personagem histórico no texto de referência] Henry Briggs que fez a base decimal... e no Problema foi o João Napião que é como se fosse o John Napier... Professor: Exato... é isso mesmo... não é a fidelidade aos fatos históricos que é importante [nesse caso]... mas sim a necessidade de pensar de uma determinada forma.

(RPG, TAC-E5-GZ, EF)

Na discussão envolvendo os membros do grupo Z, verificamos uma tendência ao reconhecimento dos estudos de HM como fonte para captação da essência da necessidade histórica do conceito. A referência e concordância de RPG com a conclusão de PNL, afirmando que "é como se o aluno revivesse a história" (RPG, TAC-E5-GZ, EF), indicam esse reconhecimento. Todavia, a licencianda manifestou uma preocupação com a necessidade de se resolver, em suas próprias palavras, "questões" que não teriam relações diretas, explícitas, com a história do conceito. Entendemos que tal preocupação, a princípio, remete a uma compreensão de uma organização fundamentada no treinamento para se resolver Problemas, ou questões de aplicação, segundo determinados modelos. Desse modo, a investigação da solução para o Problema proposto, ainda que seja funcional para a compreensão do conceito, não possibilitaria o "treinamento" de "questões" outras que não tivessem sido explicitamente abarcadas, como questões de vestibular, por exemplo.

A intervenção provocativa do professor nesse contexto buscou suscitar uma reflexão por parte da licencianda a respeito da finalidade da proposição do Problema. Sendo o Problema um elemento desencadeador de aprendizagem, é a partir dele (mas não exclusivamente com a solução dele) que a aprendizagem se torna possível. A aprendizagem, nesse contexto, pressupõe a apropriação do conceito, como já 
defendemos anteriormente, superando a mera reprodução de modelos memorizados, baseada na aparência do conceito para efeitos de aplicação imediata.

A ideia de superação aqui remete à superação presente na síntese, como é compreendida a partir das premissas do método materialista-dialético, ou seja, não pressupõe o rompimento total nem com as ideias das teses e nem com as das antíteses, mas sua superação na síntese, que não nega, necessariamente, suas premissas, mas as incorpora naquilo em que são, porventura, relevantes. Desse modo, na perspectiva histórico-cultural, enquanto método materialista-dialético que é, a compreensão do Problema como desencadeador de aprendizagem não nega a relevância do Problema contextualizado para aplicação direta de definições, algoritmos ou propriedades. A essência desencadeadora do Problema, nessa perspectiva, pressupõe suscitar necessidades tais que possibilitem que, no contexto da SDA proposta pelo professor, que inclui o planejamento do movimento de solução e outros aspectos necessários para isso, o licenciando entre em atividade.

É nesse contexto que a conclusão que DFS havia apresentado, de que "a história da matemática, então, ajuda no planejamento [da aula] [e não apenas] para conhecer as pessoas que descobriram as coisas na matemática ou pra ver como eles fizeram" (DFS, TAC-E5-GZ, EF) ganha importância como síntese de um movimento dos sentidos pessoais sobre o papel da HM na formação de professores de matemática, em relação à possibilidade de indicar as necessidades que levaram a humanidade a produzir o que produziu. A ratificação do professor ao afirmar que "diria que é para ver [o] porquê eles tiveram que fazer da forma como fizeram" buscou evidenciar aos licenciandos, como síntese geral de grupo, que os estudos de HM na formação de professores supera a mera comparação entre o que fazemos hoje e aquilo que se fazia no passado ou mesmo a apresentação de figuras históricas compreendidas como "seres especiais" e passa a ser concentrada nos estudos que visam identificar nessa história a essência dos conceitos a serem ensinados.

A identificação da essência conceitual não poderia ser confundida, também, com uma suposta superficialização dos conceitos a serem ensinados. Não se trata de ensinar apenas o essencial. Ao contrário disso, trata-se de, em um movimento de aprendizagem que é histórico e cultural, tomar como ponto de partida a gênese histórica do conceito, 
com vistas a suscitar necessidades tais que permitam a apropriação teórica do conceito, isto é, da produção humana em sua complexidade e profundidade e não apenas nos aspectos aparentes e superficiais da mera aplicação.

\subsubsection{Síntese do isolado B}

Nesse isolado identificamos um movimento de ressignificação coletiva, a partir de indícios de alterações de sentidos pessoais, que convergiu para a superação da compreensão dos estudos de $\mathrm{HM}$ com fins em si mesmos, visando a comparação anacrônica de aspectos atuais com o passado dos conceitos em estudo, para uma compreensão de que tais estudos assumem um papel fundamental na organização da atividade pedagógica que é o de buscar identificar a essência das necessidades históricas que culminaram no desenvolvimento histórico dos conceitos. Esses estudos subsidiam a elaboração ou a reelaboração de Problemas que simulem em sala de aula essas necessidades e possam assim contribuir, no contexto da SDA na AOE, para o desencadeamento da aprendizagem.

Como verificamos em nosso episódio $\mathrm{B} 1$, o movimento dos sentidos pessoais dos licenciandos sobre a HM qualifica a aprendizagem da organização da atividade pedagógica e, com isso, contribui para a constituição de novos sentidos pessoais sobre Problemas e seu papel nas aulas de matemática.

Defendemos os estudos de HM, nesse contexto, como meio de superação de uma História da matemática cronológico-geográfica, na formação de professores, para colocar em evidência uma História da matemática Conceitual, conforme definimos no subcapítulo 2.3, que contribui significativamente para a aprendizagem da organização da atividade pedagógica, objetivo fundamental nos cursos de licenciatura.

Apresentamos, na figura 15, uma síntese do movimento de alterações de sentidos que identificamos e apresentamos nesse isolado. Naquela imagem buscamos indicar o movimento dialético entre o movimento dos sentidos pessoais dos licenciandos e a significação de Problema em uma perspectiva histórico-cultural.

Os sentidos pessoais iniciais sobre a importância dos estudos de HM, apresentados à esquerda na imagem, emergiram do movimento realizado durante a etapa exploratória pré-experimento formativo, especialmente a partir de considerações 
dos licenciandos no encontro E6 daquele semestre. O movimento dos sentidos que destacamos neste isolado ocorreu, como apresentamos no episódio B1, no contexto do experimento formativo, nos encontros E4, E5 e E6. Compreendemos que os sentidos iniciais se relacionam com significados sociais relacionados à $\mathrm{HM}$ como um fim em si mesma no contexto da contação de histórias. O movimento dos sentidos, no entanto, parece convergir para um significado social que compreende os estudos de HM como fundamentais para indicar as necessidades humanas que desencadeiam a produção histórica do conhecimento e, nesse contexto, torna-se fundamental também para a produção ou adaptação de Problemas que possam ser desencadeadores de aprendizagem. 
Figura 15: Síntese do isolado B

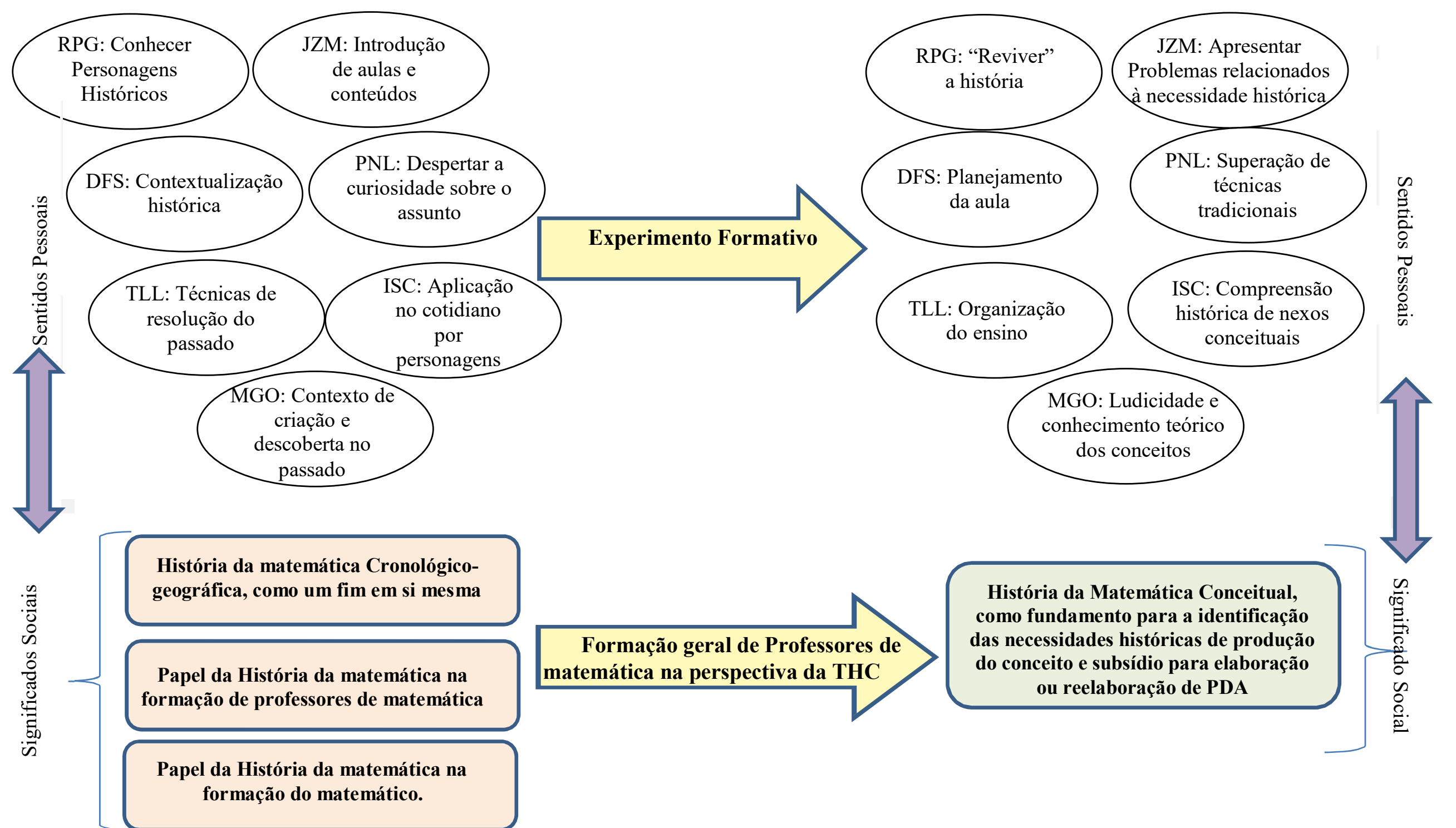

Fonte: Elaborado pelo autor 


\subsection{Relações entre o significado de PDA e o movimento de alteração de sentidos pessoais dos licenciandos sobre o papel do Problema nas aulas.}

Como vimos até aqui, nos subcapítulos 2.1 e 2.4, o movimento histórico de significação sobre o conceito de Problema foi produzindo significados sociais que, no contexto das práticas de ensino da matemática, em geral, remetem a seus usos em sala de aula e aos processos de resolução. Tais significados, ainda conforme o aporte teórico que adotamos, já tratado, relacionam-se dialeticamente com o movimento de atribuição e eventuais alterações de sentidos pessoais sobre o que tornaria um Problema adequado às práticas de ensino. Em suma, entendemos que essa "adequação", por sua vez, se relaciona com os aspectos teóricos e metodológicos envolvidos nas práticas docentes. Em outras palavras, o que caracterizaria um Problema "bom" ou "ruim" depende dos objetivos a partir dos quais o Problema é proposto.

Os significados sociais são produto tanto do processo de significação histórica da humanidade, em um caráter universal, quanto no contexto singular que envolve, por exemplo, a formação inicial de professores na universidade. Dessa forma, os diversos significados de Problema produzidos historicamente pela humanidade relacionam-se dialeticamente com os significados que circulam nos meios acadêmicos singulares e, a partir destes, também influenciam e são influenciados pelos sentidos pessoais que os licenciandos atribuem e vão modificando.

É desse contexto que emerge o terceiro isolado que remete às relações dialéticas verificadas entre os significados sociais produzidos no processo histórico de significação e os sentidos pessoais dos licenciandos sobre o papel do Problema em sua preparação para a docência, de modo a aferir uma possível alteração de sentidos que convirja para uma aproximação do conceito de PDA e de seu papel do contexto da SDA. Os episódios que destacamos remetem ao contexto em que os sentidos dos licenciandos se aproximam de uma compreensão do papel do Problema no contexto da Situação Desencadeadora de Aprendizagem. Tratam também da presença dos Problemas nos relatórios de estágio supervisionado e das inferências de alterações nos sentidos 
pessoais iniciais dos licenciandos que pudemos verificar a partir das propostas de regência, segundo aqueles relatórios.

\subsubsection{Episódio C1: O PDA no planejamento da SDA.}

Este episódio trata do movimento em que verificamos indícios de alterações de sentidos pessoais dos licenciandos que remetem à compreensão do Problema como mediador entre a situação desencadeadora de aprendizagem e o movimento históricológico em que o conceito matemático é produzido.

Um momento em que pudemos destacar essa compreensão ocorreu no contexto do encontro em que apresentamos aos licenciandos o "Jogo de Adivinhação". Esse jogo já havia sido proposto no movimento inicial a partir do qual verificamos os sentidos iniciais dos licenciandos e foi indicado por um dos licenciandos cujo movimento formativo acompanhamos em nossa análise, MGO. Retomamos esse jogo como SDA no experimento formativo em razão de seu potencial para evidenciar a relação dialética que pretendíamos. Os conceitos matemáticos envolvidos no jogo se relacionavam com ideias a respeito de equações polinomiais do primeiro grau, especialmente os conceitos de igualdade, incógnita e operações inversas.

No primeiro semestre os licenciandos jogaram em duplas, recebendo cinco caixinhas de fósforo cada um, certa quantidade de palitos de fósforo e uma folha com os comandos a serem realizados. Os comandos de cada integrante da dupla eram sempre distintos entre si. Um dos componentes da dupla, segundo um comando disposto na folha, poderia introduzir certa quantidade de palitos dentro da caixinha sem 0 conhecimento do parceiro, juntar caixinhas com fita adesiva, deixar palitos à vista fora da caixinha, etc. Em seguida deveria anunciar ao colega de dupla uma quantidade de palitos. O objetivo seria, então, "adivinhar" a quantidade de palitos oculta dentro de cada caixinha ou de um conjunto de caixinhas.

Por exemplo, um dos comandos da folha era: "introduza, sem seu coloca ver, seis palitos em cada uma de duas caixinhas e coloque-as fechadas sobre a mesa ao lado de outros oito palitos, à vista do seu colega. Anuncie para ele que na mesa há, no total, 20 palitos. Ele deve adivinhar a quantidade de palitos em cada caixinha. Sabemos que a solução para o Problema é dada pela resolução da equação polinomial de primeiro grau 
$2 x+8=20$. O Problema, no entanto, consiste em encontrar uma estratégia vencedora para "adivinhar" sempre a quantidade de palitos ocultos dentro da caixinha. Entendemos que esse Problema supera a aplicação de técnicas de "tradução" da linguagem corrente para a linguagem algébrica e a aplicação de técnicas de resolução de equações mecanicamente memorizadas que envolvem uma linguagem comprometedora do rigor matemático, como "passa para o outro lado, troca o sinal", que nossa experiência verifica ser recorrente no ensino de equações.

O Problema enfrentado a partir do "Jogo de Adivinhação" possibilita a compreensão dos conceitos de incógnita, de igualdade e operações inversas, além de suscitar a necessidade de busca próprias de estratégias de resolução de uma equação polinomial de primeiro grau. Os demais comandos da folha remetiam a situações com quantidades negativas, equações fracionárias, entre outras.

Já no experimento formativo os licenciandos que já haviam participado do jogo no semestre anterior foram convidados a apresenta-lo aos demais - que não o conheciam - e discutirem comparativamente a proposta decorrente do jogo e as estratégias tradicionais para o ensino de equações. Eles apresentaram os relatórios de aula, com a síntese das discussões de cada grupo, em que registraram suas considerações a respeito da proposta. Dos relatórios pudemos verificar as considerações do grupo que resumimos no quadro 8 :

\begin{tabular}{|c|c|c|}
\hline Grupo X & Grupo Y & Grupo Z \\
\hline $\begin{array}{l}\text { - Criticam métodos } \\
\text { tradicionais sobre a } \\
\text { memorização de técnicas; } \\
\text { - Enaltecem o caráter } \\
\text { lúdico e a possibilidade de } \\
\text { manusear criticando } \\
\text { concretos, materiais } \\
\text { propostas que falam sobre } \\
\text { "balanças", mas que as }\end{array}$ & $\begin{array}{l}\text { - Criticam métodos de } \\
\text { ensino mecanicistas que } \\
\text { preveem "receitas" a serem } \\
\text { memorizadas para resolver } \\
\text { equações; } \\
\text { - Citam o aspecto lúdico } \\
\text { como importante para } \\
\text { envolver os alunos na } \\
\text { atividade; }\end{array}$ & $\begin{array}{l}\text { - Relacionam o movimento } \\
\text { realizado no jogo com o } \\
\text { movimento estudado na } \\
\text { HM sobre o conceito de } \\
\text { equações; } \\
\text { - Indicam que o jogo ajuda } \\
\text { a desenvolver "o raciocínio } \\
\text { lógico" para não precisar } \\
\text { utilizar técnicas mecânicas } \\
\text { para resolver equações; }\end{array}$ \\
\hline
\end{tabular}




\begin{tabular}{|c|c|c|}
\hline $\begin{array}{l}\text { balanças nunca estão } \\
\text { disponíveis. } \\
\text { - Reconhecem a relação } \\
\text { entre o movimento } \\
\text { envolvido no jogo e os } \\
\text { aspectos estudados sobre } \\
\text { a HM do conceito de } \\
\text { equações. }\end{array}$ & $\begin{array}{l}\text { - Indicam que o jogo é um } \\
\text { "motivador" na } \\
\text { aprendizagem. }\end{array}$ & $\begin{array}{l}\text { - Afirmam que } 0 \text { aluno } \\
\text { "constrói" } \quad \text { o próprio } \\
\text { conhecimento. }\end{array}$ \\
\hline
\end{tabular}

Fonte: Elaborado pelo autor a partir dos relatórios de aula dos licenciandos

A partir desse quadro-resumo, verificamos que os três grupos reconheceram aspectos importantes que relacionam a SDA com o movimento histórico-lógico de desenvolvimento do conceito envolvido no jogo. Os integrantes do grupo $X$ estabeleceram importante crítica a métodos de ensino que utilizam técnicas mecanicistas que remetem à memorização de "passos" para se resolver equações e utilizam termos que se relacionam com a aparência externa do fenômeno. Segundo a indicação deles os próprios alunos (supomos que estariam se referindo aos alunos durante aulas de matemática em que o professor adotasse tais métodos mecanicistas) ficavam "confusos" - eles utilizam o termo "confusos".

\begin{abstract}
Nas aulas sobre equações no $7^{\circ}$ ano o livro ou o caderno do aluno ${ }^{29}$ fala sobre balanças e equilíbrio, mas na hora de explicar a matéria o professor fala 'passa pra cá passa pra lá' e os alunos ficam confusos porque eles sabem que na balança se você tira uma coisa de um lado e coloca do outro a balança desequilibra e daí ele [o aluno] não entende. (GX-E7, RTC, EF).
\end{abstract}

A crítica dos licenciandos remete à contradição entre o que aponta o material didático que os alunos têm disponível, sua experiência de vida - quando afirmam que "eles sabem que na balança se você tira uma coisa de um lado e coloca do outro a balança desequilibra" - e aquilo que o professor está apresentando. Ao tratar desse aspecto na discussão que realizamos na síntese do encontro o professor questiona:

Professor: Vocês acham que o jogo supera essa abordagem mecânica?

\footnotetext{
${ }^{29}$ No estado de São Paulo, a rede pública disponibiliza um material didático que cumpre um papel análogo ao do livro didático. Esse material é conhecido como "caderno do aluno".
} 
MGO: Sim, professor... os alunos se envolvem. Eles aprendem e o professor não mente pra eles... [risos]

Professor: E o que seria "mentir" pra eles?

MGO: Ah... é tipo que nem nesse caso... o aluno não tá tirando nada de um lado e jogando pro outro... ele tá tirando dos dois lados... ou colocando dos dois lados... eu fiz [utilizou] esse jogo na regência... no ano (sic) passado ${ }^{30} . .$. e eles entenderam melhor do que nas vezes que eu fiz "passa pra lá passa pra cá"... eles entenderam... até os que já sabiam, entenderam.

Professor: Ah... legal... e porque você fez [utilizou] esse jogo?

MGO: Porque a gente tinha usado na aula aqui... e eu achei interessante... aí o professor [supervisor de estágio] ia ensinar funções e ia fazer revisão de equações... aí eu fiz [utilizou] o jogo.

Professor: $\mathrm{E}$ você acha que é diferente do que você fazia antes porquê?

MGO: Porque eles fazem pegando [manuseando o material] eles pensam e podem até chutar [resolver por tentativa e erro] mesmo... mas depois eles acham um jeito de fazer.

Professor: E vocês [referindo-se aos demais alunos da turma] acham que é diferente porquê?

(MGO, TAC-E7-GX, EF)

A indicação de MGO sobre sua experiência com o mesmo jogo, além do aspecto comparativo que ele testemunha em relação aos resultados que obteve e aqueles que verificava quando utilizava, em suas próprias práticas, técnicas mecanicistas, possibilita que o professor questione os demais licenciandos sobre as razões porque considerariam que as abordagens distintas. Vem do grupo Z uma indicação importante:

DFS: Eu acho que aqui [no jogo] é diferente porque o aluno constrói o próprio conhecimento... eu acho isso importante... porque não é você que faz e nem ensina a fazer (sic)... é o aluno que aprende a fazer... e depois você mostra pra ele o que ele fez.

Professor: Você disse que ele constrói o próprio conhecimento... como assim?

DFS: É, professor... tipo, ele que faz... não é como você fazer pra ele ver e ele fazer depois igual... ele que faz... igual no caso lá do [Problema sobre o] carnê da previdência... nós "erramos" porque no fim das contas era a gente que resolvia [o Problema] e não os alunos.

Professor: Éh... naquele caso vocês fizeram um Problema sobre porcentagem e não sobre Juros, lembra?

DFS: Isso... isso... e os alunos não estavam construindo nada.

Professor: Eu não tô entendendo o que você tá chamando de "construir".

RPG: É a gente não resolver antes pra ele repetir, professor. Ele que vai pensar e construir sozinho.

(DFS e RPG, TAC-E7-GZ, EF)

Parece-nos que o movimento realizado pela turma em torno do Problema apresentado pelo grupo $Z$ no encontro em que deveriam apresentar um plano de aula que utilizasse um Problema sobre o conceito de Juros Simples foi relevante para uma

${ }^{30} \mathrm{Na}$ verdade foi no semestre anterior 
possível mudança de sentidos pessoais sobre o Problema, por parte de DFS. Aqui ela demonstra uma preocupação com o papel do aluno na proposição do Problema. Ao utilizar a expressão " o aluno constrói o próprio conhecimento" (DFS, TAC-E7-GZ , EF) DFS parece estar se referindo a um movimento em que o professor não é mais modelo a ser seguido, mas propositor de um movimento, ou - melhor ainda - de uma situação capaz de desencadear a aprendizagem.

No entanto, receamos que, naquele momento, a licencianda estivesse fazendo alguma comparação com a teoria de origem piagetiana conhecida como "construtivismo". Por isso nosso questionamento como professor visa aferir alguma relação entre a fala da licencianda e alguma suposta relação com aquela teoria. Ao questionar o que ela estaria entendendo como "construir o próprio conhecimento", no entanto, a resposta vem da colega (supomos que foi RPG quem, nas discussões do grupo utilizou o termo "construir"). Como RPG não faz referência explicita à teoria, mas, ao contrário, explica que por construir estão compreendendo uma inversão no movimento de apresentar um modelo a ser seguido e depois os alunos repetirem o modelo, consideramos que as discussões a partir do Jogo de Adivinhação possibilitaram reconhecermos um movimento de seus sentidos pessoais iniciais, movimento este que remete ao Problema apresentado pelo professor que poderia possibilitar que os alunos entrem em atividade.

Continuando aquela conversa, em razão de DFS e RPG terem referenciado a possibilidade de o aluno "aprender sozinho", fizemos mais algumas provocações:

Professor: Dá para o aluno aprender sozinho?

RPG: Não... não é aprender sozinho... sozinho mesmo... [risos]... é ele fazer sem ajuda...

Professor: E se ele tiver ajuda? Digamos, de um colega dele. Pense assim: um aluno, lá no $6^{\circ}$ ano, não consegue achar uma estratégia... ele fica chutando... e o colega de dupla dele já achou e conta pra ele a estratégia pra ele conseguir nas próximas. Você diria que ele aprendeu ou não?

DFS: O que ensinou ou o que não conseguiu [sozinho]?

Professor: $O$ que não conseguiu.

RPG: Aprendeu... [depois de alguns instantes]... acho que aprendeu... aí que tá, professor... se o colega contar eu acho que ele aprende... e se o professor contar também... então, por que o professor não pode falar antes?

Professor: Quem disse que não pode?

DFS: Você.

Professor: [rindo] Eu? Vamos ver... [referindo-se aos demais] o professor, nesse contexto aqui, pode contar ou não pode pessoal?

(DFS e RPG, TAC-E7-GZ, EF) 
Aqui as licenciandas parecem ter reconhecido uma contradição entre a conclusão a que RPG havia chegado a partir de sua interpretação do Jogo de Adivinhação e aquela que havia concluído a partir da proposta de elaboração de um Problema sobre Juros Simples. Tanto em uma situação quanto noutra RPG, ao que parece, vinha compreendendo que as conclusões não deveriam ser apresentadas pelo professor, a priori, mas deveriam ser tomadas pelo aluno, e só por ele. Ao ser questionada se, no movimento do jogo, um colega contasse ao outro qual a estratégia vencedora, ela interpretou que, mesmo assim, o aluno que recebeu "a dica" poderia aprender. Sua questão, então, passou a ser algo como "se o colega pode contar a estratégia ao outro e mesmo assim ele pode aprender, porque o professor não pode, a priori, apresentar 'a estratégia' ao aluno?". Ao invés de respondermos, devolvemos ao grupo o questionamento. Veio do grupo $X$, após algumas tentativas de alguns colegas, a resposta que destacamos.

MGO: Acho que o importante não é se o aluno descobre ou se contam pra ele. O importante é que ele quer descobrir a resposta.

Professor: Ah... que legal... explique essa ideia MGO.

MGO: Que nem... no negócio lá [Problema] da previdência... eu mesmo disse que era legal porque era da realidade deles [alunos de EJA]... só que [o Problema] era sobre porcentagem... então o aluno só precisava fazer a porcentagem... a resposta que ele precisava dar era sobre porcentagem...e não sobre juros... eu acho que se os alunos queriam dar a resposta, tinha que aproveitar essa vontade deles e relacionar com os juros que era a ideia. Agora é a mesma coisa... se o menininho quer saber uma estratégia e não conseguiu fazer sozinho, mas um colega conta pra ele, então ele aprende... acho que é isso. Professor: Vocês concordam? (referindo-se ao grupo Z)

DFS: Faz sentido... se o aluno quer ele aprende... também penso assim... mas como fazer ele querer?

Professor: O [MGO] disse que tem que aproveitar a vontade do aluno, num foi? Vamos pensar que em vez de aproveitar, o professor crie [dando ênfase ao verbo "criar"] essa vontade. O que aconteceria lá no Problema da Previdência e aqui no jogo?

DFS: Ãhn... entendi... no Problema da guia da previdência ele só resolvia porcentagem...

Professor: [interrompendo] porque o Problema só poderia criar a vontade de resolver porcentagens...

DFS: Ah... sim... e o jogo cria a vontade de adivinhar sem precisar ficar chutando [método de tentativa e erro].

(MGO, TAC-E7-GX, EF ; DFS, TAC-E7-GZ, EF)

Entendemos que DFS retoma, ao mesmo tempo, uma compreensão que reconhece a necessidade da necessidade e um papel do Problema na aula, ou, como parece mais próximo do movimento que pretendíamos, o papel do PDA na SDA. A 
"vontade" referida por MGO, entendemos, seriam, no contexto da teoria da atividade (LEONTIEV, 1978), os motivos que são suscitados pelas necessidades. Em sua compreensão, ao que parece, se o Problema suscita necessidades que produzem motivos que podem se tornar eficazes, o aluno busca objetos que podem satisfazer a tais necessidades, ou seja, o movimento descrito por MGO parece descrever o movimento da atividade. DFS parece ter compreendido uma distinção que existe, neste contexto, entre as ações em que o professor demonstra o que deve ser feito e aquelas em que ele orienta para que o aluno faça. Nesse movimento, cabe ao professor criar situações em que o aluno, de acordo com MGO, "sinta vontade de dar uma resposta".

Essas situações estabelecem o contexto em que o movimento ocorre, apresentam as instruções e as regras. Quando é apresentado o objetivo da situação (ou seja, quando se conhece o Problema desencadeador) inicia-se o movimento que é concluído quando tal objetivo é alcançado. No caso do jogo (o "Jogo da Adivinhação" ou qualquer outro) essa característica fica evidente. A "vontade de dar uma resposta", a que MGO se refere, no caso do jogo, remete ao movimento que visa encontrar uma estratégia vencedora que é também o objetivo (o motivo, na TA). Quando tal objetivo está relacionado a uma situação de aprendizagem, podemos dizer que aquele jogo constitui uma Situação Desencadeadora de Aprendizagem. Isso porque, em uma SDA, o movimento do aluno se inicia quando é estabelecido um objetivo. É também em função desse objetivo que se estabelecem o contexto, as regras e as instruções. Assim, quando o jogo é uma Situação Desencadeadora de Aprendizagem, o objetivo estabelecido para "vencer" é o problema desencadeador de aprendizagem. Enfim, quando temos o jogo como uma SDA (com contexto, instruções, regras, etc.) o problema que constitui o objetivo do jogo (ou ainda, o motivo da atividade) é o PDA.

Logo, entendemos que a análise do movimento realizado a partir das considerações dos licenciandos remete ao reconhecimento de que o Problema, enquanto elemento que está impregnado das necessidades que desencadeiam o movimento de aprendizagem, seria elemento essencial na organização da SDA e, desse modo, também de seu planejamento. Esse reconhecimento ratifica-se no contexto da análise que realizamos dos Problemas propostos pelos licenciandos para a regência de estágio e que constitui a essência do Episódio C2, apresentado a seguir. 


\subsubsection{Episódio C2: 0 uso de Problemas na regência de estágio: uma aproximação da ideia de PDA.}

O episódio apresenta a análise dos dados presentes nos relatórios de regência de estágio supervisionado, em que compreendemos haver indícios de alteração de sentidos a respeito do papel do Problema, em relação aos sentidos pessoais iniciais dos licenciandos.

A regência de JZM, na conclusão do experimento formativo, propunha o jogo Batalha Naval Geométrica ${ }^{31}$ de onde emerge um Problema com potencial para desencadear o ensino e a aprendizagem sobre o referencial cartesiano. A licencianda indica que realizou um estudo histórico do conceito, mas que não remete à história factual, em sentido estrito.

O plano cartesiano foi desenvolvido por René Descartes. O plano consiste em dois eixos perpendiculares numerados, chamados de abscissa (horizontal) e ordenada (vertical), que tem (sic) a característica de representar pontos no espaço. O matemático francês utilizou esse plano para representar planos, retas e curvas relacionando elas a equações matemáticas. Diz uma antiga lenda que ele pensou nesse sistema de representação ao observar uma mosca voando no teto. Percebeu que os pontos em que a mosca pousava no teto podia[m] ser descrito[s] pela distância da mosca de cada parede do aposento em que se encontrava. Sua descoberta da geometria analítica foi considerada uma das mais importantes na história da matemática (JZM, RES, EF).

Verificamos que a licencianda remete a uma lenda, mas que é conhecida no contexto da História da matemática. Essa lenda, por sua vez, remete à necessidade de representação de um ponto no plano. Para a satisfação dessa necessidade Descartes

${ }^{31} \mathrm{O}$ jogo consiste em espalhar por uma malha quadriculada, em que a horizontal é identificada por letras do alfabeto e a vertical por números naturais, uma "esquadra" composta por formas geométricas. $O$ quadrado representa o porta-aviões e deve ser desenhado na malha abrangendo linearmente um total de quatro quadradinhos; os triângulos são os bombardeiros e devem ser agrupados linearmente de três em três, dispostos na vertical ou na horizontal segundo a opção dos participantes; os círculos são os salvavidas e são agrupados de dois em dois, também na horizontal ou na vertical e, por fim, os botes de resgate são losangos individuais. Cada participante (o jogo não é jogado necessariamente por duplas, mas por oponentes, podendo cada oponente ser composto por uma ou mais pessoas) dispõe de dois porta aviões, três bombardeiros, quatro salva-vidas e cinco botes de resgate para distribuir. $\mathrm{O}$ jogo, em si, consiste em anunciar um "tiro" com uma coordenada Letra-Número, que deve ser reconhecida pelo oponente como "tiro n'água" quando não acertar nenhum dos navios ou indicar qual foi o navio acertado pelo "tiro". Vence o jogo quem eliminar toda a esquadra adversária primeiro. 
teria adotado duas retas perpendiculares com escalas proporcionais a partir das quais teria referência para indicar o que hoje reconhecemos como pares ordenados.

JZM apresenta um jogo que tem por objetivo inicial "eliminar toda a esquadra adversária" (JZM, RES, EF). Na teoria da atividade (LEONTIEV, 1978) poderíamos reconhecer este como um motivo compreensível, ou seja, o motivo que coloca o aluno em um movimento inicial.

Em suas considerações sobre a regência a licencianda indica que entende que a proposta seria, idealmente, realizada como "introdução" do conceito, mas a professora supervisora não permitia que as propostas dos estagiários iniciassem conteúdos novos, de modo que ela (a professora) teria que ensinar primeiro e depois os estagiários poderiam propor o que a professora supervisora classificava como "atividades complementares". Foi esse o contexto em que ela efetivou a proposta. Em seu relato, no entanto, a licencianda enaltece o que considerou "mais gratificante", indicando aspectos que não tinham "ficado claros" para os licenciandos antes. Cita como exemplo, a convenção de que, na representação do par ordenado, a abscissa é indicada primeiro e depois a ordenada (nas palavras de JZM, "o valor de x é escrito antes e o de y depois"). Como os alunos indicavam seus "tiros" seguindo um padrão letra-número, sendo as letras representadas no eixo horizontal e os números no eixo vertical, os alunos aceitaram melhor a convenção, sendo que antes eles invertiam a representação, apesar dos esforços da professora para que decorassem a convenção.

De acordo com JZM, os licenciandos perceberam que se acertassem o portaaviões os próximos "tiros" tinham que ser dados em quadrados adjacentes (a licencianda utiliza o termo "do lado") na vertical ou na horizontal, de modo que "quando acertavam outro já sabiam a direção em que o navio estava posicionado" (JZM, RES, EF). A licencianda indica que esta seria uma boa oportunidade para mostrar, no contexto da Geometria Analítica, que dois pontos determinam uma reta. Inferimos que, dado o contexto que a licencianda descreve sobre as opções da professora supervisora, ela não tenha relacionado a "descoberta" dos alunos com o conceito que ainda seria tratado.

Todavia, compreendemos que a licencianda reconhecia os momentos em que o motivo compreensível (eliminar os navios do adversário) poderia se tornar um motivo eficaz (compreender a localização por pares ordenados) na SDA. 
Os sentidos pessoais iniciais de JZM, como indicamos no subcapítulo 4.1, indicavam que os Problemas seriam "desafios" a serem apresentados aos alunos nas aulas como uma forma de "dar uma aula diferente" (JZM, TAI-E1, PEF ; JZM, RES, PEF). O caráter lúdico da aula parece permear esse sentido inicial e ter permanecido como essência de sua compreensão a respeito do Problema. Ela distinguia a mera resolução de exercícios da aplicação da "matéria", do conteúdo, em situações cotidianas. Todavia, após nosso experimento formativo, a licencianda passa a referenciar um aspecto do qual parece ter se apropriado no contexto de seus estudos sobre história da matemática e propõe um jogo aos alunos para o qual a essência do conceito matemático verificada, também está presente. Ela indica que aquele jogo seria adequado para fazer a "introdução" de sua aula, lamentando não poder realizar a regência dessa forma, indicando que compreende sua proposta não mais como mera aplicação do conteúdo ensinado em situações do cotidiano. Verificam-se, inclusive indícios de um reconhecimento de possíveis mediações entre as estratégias percebidas no jogo e um conceito matemático distinto daqueles que os alunos já conheciam (e que poderiam, portanto, conhecer a partir do jogo). Esses são indícios sobre o movimento dos sentidos de JZM, tudo indica, convergiram para um significado social de Problema produzido no contexto da THC, em que estes assumem na SDA o protagonismo por estarem impregnados das necessidades que podem desencadear o movimento de aprendizagem.

Já as licenciandas DFS e PNL indicaram que realizaram suas regências a partir de um mesmo Problema elaborado coletivamente ${ }^{32}$. O Problema também emergiu da proposta de um jogo e foi indicado para o ensino do conceito de funções. A proposta indicava o seguinte:

\footnotetext{
32 Durante o planejamento da regência, no decorrer do curso, em alguns momentos a configuração dos grupos como apresentamos aqui foi desfeita para que os licenciandos se reagrupassem segundo a afinidade dos temas que seriam objeto de suas regências, de acordo com o que combinassem em suas respectivas escolas com seus professores supervisores. Nesse contexto, ficou estabelecido que os Problemas poderiam ser coletivamente elaborados e utilizados nas regências de quem desejasse adotáIos. O Problema elaborado e adotado nas regências de PNL e DFS também foi utilizado na regência de outros dois licenciandos, totalizando quatro situações distintas coordenadas pelos licenciandos em suas respectivas (e distintas) escolas.
} 
A atividade consiste em um jogo de cartas, com 40 cartas para cada dupla, sendo 10 de cada tipo, além de 15 peças individuais com estampas de plantas (5), carneiros (5) e lobos (5).

Além das cartas mencionadas, há outras 20 cartas com situações diversas, chamadas fenômenos, que indicam nascimento, invasão ou morte dos personagens envolvidos.

A dinâmica do jogo segue os seguintes critérios:

- Cada carta de planta, carneiro e lobo equivale a 5 dos indivíduos estampados e a de humanos apenas um;

- Cada planta alimenta um carneirinho;

- Cada carneirinho alimenta um lobo;

- Cada carta de humano consegue afugentar uma carta de lobo (ou seja, ele pode afugentar até 5 lobos).

- A fazenda tem um limite para cada espécie. O máximo de plantas é de 50 unidades. $O$ máximo de carneirinhos é de 25 unidades. $O$ máximo de lobos permitido é de 15 unidades. O máximo de humanos que a fazenda suporta é de 10 unidades.

As regras do jogo são as seguintes: A fazenda inicia com três cartas de plantas (15 plantas), duas cartas de carneiros (10 carneiros), dois lobos e um humano. $O$ jogador escolhe uma carta de fenômeno e obedece ao que está descrito nela. Feito o que se pede, o jogador poderá acrescentar apenas uma carta ou peça à sua fazenda com a intenção de equilibrar o ciclo. Terminada a jogada, o ciclo precisa ser feito começando pela quantidade de humanos: se há humanos suficientes para afugentar os lobos, nada acontece com os carneiros, mas as plantas serão devoradas, então, para cada carneiro, uma planta sai do jogo e as cartas dos lobos afugentados também. Se não há humanos suficientes para afugentar todos os lobos, para cada lobo não afugentado um carneiro morre (as cartas ou peças do carneiro saem do jogo) e para cada carneiro restante, uma planta é devorada.

O jogo segue essa dinâmica até que um dos fatos aconteça:

- Acabar as cartas de fenômenos;

- Acabar as plantas;

- Os limites da fazenda serem ultrapassados;

- Ter a morte de todos os carneirinhos.

Quando algum desses fatos acontecer, o jogo acaba. Vencerá a dupla que mais tiver carneirinhos vivos, sem ultrapassar os limites da fazenda (DFS, RES, EF, p. 30 a 32 e PNL, RES, EF, p. 8-9)

\section{DFS explicitou em seu relatório a pesquisa relacionada à HM que realizaram a fim}

\section{de propor o jogo em sua regência de estágio. Segundo ela}

[...] autores como Boyer (1996) e Eves (2004) afirmam que, inicialmente, o homem passou a associar objetos aos animais e demais seres vivos que precisavam ser contados, como no caso de um rebanho de ovelhas. Pela dificuldade de estimar quantos animais possuía, uma vez que os números ainda não tinham sido criados, o antigo pastor colocava uma pedra em um saco para representar um animal: a ideia da unicidade foi fundamental para o desenvolvimento do conceito de função. Feito dessa forma, o homem criou uma dependência entre a quantidade de animais e a quantidade de pedras colocadas na sacola, permitindo um controle sobre seu rebanho (DFS, relatório de estágio, p. 29). 
Compreendemos que uma necessidade histórica que envolve um nexo conceitual do conceito matemático de função, a relação biunívoca, que seria a comparação entre grandezas que apresentam relação de dependência entre si, se verifica no estudo de HM que a licencianda evidencia e que fez parte do experimento formativo desenvolvido. Ao indicar que, no desenvolvimento do ato de jogar, os alunos deveriam organizar "os dados [decorrentes das anotações] em tabelas referentes às quantidades finais, de modo que o valor que não depende do outro esteja em ordem crescente" (DFS, RES, EF, p. 32, destaque meu) a licencianda evidencia a necessidade de os licenciandos reconhecerem, no decorrer da busca pela estratégia de vitória, uma relação de dependência entre as grandezas presentes no jogo.

Na sequência, indica DFS, "os estudantes organizam esses dados e desenham um gráfico para representar as situações vivenciadas durante o jogo" (DFS, RES, EF, p. 32). Com isso, seria possível superar as tradicionais representações gráficas de funções estabelecidas a priori, já que os dados que darão origem aos gráficos decorrem de partidas distintas, o que implica que os gráficos seriam diferentes entre si. Assim, cria-se a possibilidade de que os alunos não busquem desenhar gráficos idênticos aos demais, mas sim identificar tendências reconhecendo a função como uma possibilidade de acompanhamento de um fenômeno. Nesse contexto, poderiam os alunos, ainda, dar novos sentidos às suas compreensões sobre gráficos, reconhecendo padrões segundo suas escolhas, compreendendo a possibilidade de "previsão" como um dos elementos impregnados no conceito de função.

A partir do desenvolvimento da proposta em seu estágio supervisionado, dentre outras relevantes considerações, DFS indica que "toda a experiência que obtive [ela obteve] durante os estágios 3 e 4 [referência ao movimento formativo] foi valiosa para a minha [dela] formação, não apenas como profissional [docente], mas também como ser humano" (DFS, RES, EF, p. 35).

Verificamos indícios de que os sentidos pessoais de DFS sobre Problema eram fortemente marcados por uma tendência à aplicabilidade de conteúdos já apresentados previamente, conforme indicamos no subcapítulo 4.1 e, também, na proposição do Problema sobre juros simples no encontro E2 do experimento formativo. No entanto, identificamos um movimento de seus sentidos convergindo para o entendimento de que 
o papel do Problema em suas aulas fosse colocar o aluno em um movimento desencadeador de aprendizagem. Durante o experimento formativo a licencianda mostrou indícios de um reconhecimento de que o papel do professor não seria mostrar modelarmente como fazer, mas sim criar condições para que o aluno passasse a ter a motivação para fazer. Essa motivação seria desencadeada pelo Problema, de modo que caberia ao professor propor situações que suscitassem esse Problema. Em sua proposta de regência, essa compreensão parece estar presente.

Ao propor o jogo, DFS não o assume como um fim em si mesmo e nem como instrumento de aplicação do que já foi ensinado. Indica que os alunos fazem anotações durante as partidas para poder investigar o movimento e estabelecer estratégias de vitória e que tais estratégias se relacionam ao conceito de função. Entendemos que estes são importantes indícios de alteração em seus sentidos pessoais não apenas em relação ao papel do Problema em suas aulas, mas também, ao que parece, do próprio papel do professor na aula de matemática.

PNL faz indicações mais sucintas em seu relatório de estágio, também indicando os estudos de HM para a gênese da proposta de jogo como SDA a ser desenvolvida durante a regência de estágio. Os sentidos pessoais iniciais de PNL indicavam que o Problema deveria remeter a situações da realidade e ajudar os alunos a estarem preparados para resolver os Problemas de avaliações como concursos e vestibulares. Quando opta por utilizar em sua regência um jogo elaborado (ou adaptado) para colocar o aluno diante da necessidade de acompanhar variações entre grandezas, PNL também apresenta indícios de uma superação da aplicabilidade do conteúdo ensinado (como preparação para o vestibular, por exemplo) em benefício de uma proposta que coloca em evidência um movimento em que o Problema desencadeia um movimento que é percorrido pelo aluno.

O movimento dos sentidos pessoais de PNL remete, a nosso entender, a uma aprendizagem da organização do ensino. Entendemos que a possível alteração nos sentidos pessoais da licencianda, que supera o entendimento do Problema como recurso de aplicação e o aproxima de um significado segundo o qual seria desencadeador de aprendizagem, possa ter contribuído, sem prejuízo de outros aspectos que também possam ter ocorrido fora do contexto do experimento formativo, para uma mudança dela 
em relação à docência. PNL, como vimos, afirmava explicitamente que não cogitava nem remotamente o exercício da profissão. Em seu relatório de estágio, no entanto, além de indicar os aspectos da proposta de regência que, como já indicamos, abordava o mesmo Problema também utilizado por DFS, a licencianda PNL apresenta um indício bastante significativo de alteração em sua convicção inicial, ao afirmar que seu relatório:

[...] é um breve resumo de um conhecimento apurado durante os quatro semestres entre 2016 e 2017, como também as discussões durante as aulas de estágio [disciplinas de Prática de Ensino] em que foram trazidas questões com visões críticas e necessárias para a formação [para a] docência, o que me enriqueceu em conhecimento e experiência, acrescentando ainda mais na minha vida, fortalecendo minha maturidade. Acredito que todo esse processo não só me mudou como também ajudou a me preparar para obstáculos que vou vivenciar no cotidiano da profissão e da vida (PNL, RES, EF, p. 10, grifos nossos).

$\mathrm{PNL}$, segundo o que registrou em seu relatório de estágio, reconhece-se como professora em formação inicial a partir de estudos, dentre possíveis outros, que contribuíram para a aprendizagem da organização da prática pedagógica. Esse movimento de seus sentidos pessoais parece estar relacionado para a alteração de seus sentidos sobre o próprio curso, uma vez que a aprendizagem de um modo de organização do ensino parece ter contribuído para o autorreconhecimento da licencianda como professora em formação, superando uma busca da aprendizagem da matemática como fim em si mesma para integrar a aprendizagem de aspectos sobre a organização do ensino.

RPG foi outra licencianda que também fez parte do grupo que, para o planejamento da regência, realizou estudos sobre o conceito de função. Ela, no entanto, optou por não utilizar o jogo que as colegas DFS e PNL adotaram. O que RPG pretendeu fazer foi adaptar a proposta que já tinha apresentado no semestre anterior. A alteração, no entanto, é indicativo de uma importante alteração de sentidos pessoais sobre o papel do Problema nas aulas. Ela indica a seguinte proposta:

Jonas vai abrir um estacionamento em um bairro importante de sua cidade. Para saber quanto cobrará de seus clientes ele já pesquisou e descobriu que seu principal concorrente cobra $R \$ 5,00$ pela primeira hora e mais $R \$ 2,00$ por hora adicional do estacionamento. Jonas sabe que naquele bairro os clientes costumam estacionar por períodos curtos e prefere atrair clientes que vão ficar por pouco tempo no estacionamento e deixar que os clientes que vão permanecer por mais tempo prefiram o concorrente. Como deve ser a cobrança de preços de 
Jonas, se ele preferir atrair mais os clientes que vão ficar no máximo 3 horas? (RPG, RES, EF, p. 9).

Em seu relatório, RPG ainda indica também aquilo que considerou fundamental na adaptação de sua proposição anterior:

[...] os alunos deviam resolver o problema sem ter os dados e por isso pensaram como poderiam comparar o preço do estacionamento em função do tempo. $\mathrm{Na}$ história da matemática os babilônicos também perceberam a dependência entre algumas grandezas. Eles construíram tabelas que mostravam os valores associados: uma coluna representava uma unidade principal e a outra coluna mostrava o valor correspondente àquela unidade, indicando que operação foi feita para obtê-la por meio da unidade principal (RPG, RES, EF, p. 11).

Em sua proposta realizada ao final da etapa exploratória pré-experimento formativo, RPG indicou que não pôde efetivar a regência em relação ao Problema que propôs. Dessa vez ela indica que efetivou a regência e que propôs o Problema aos alunos para que discutissem possíveis soluções. Ela indica que alguns alunos propuseram, a princípio, cobrar um preço fixo abaixo do preço inicial do concorrente. Assim os clientes que fossem ficar até 3 horas pagariam menos do que no concorrente. Os próprios alunos, no entanto, segundo o relato de RPG, perceberam que isso não resolvia o Problema, pois todos os clientes seriam atraídos pelo preço de Jonas, inclusive aqueles que pretendiam permanecer por mais de três horas. Um aluno chegou a questionar a razão pela qual Jonas preferia clientes que ficassem menos tempo. RPG indica que foi ela quem respondeu que se Jonas fizer assim, enquanto no concorrente uma vaga ficará ocupada por, por exemplo, 4 horas ele ganharia $R \$ 11,00$, enquanto Jonas poderia utilizar uma vaga para pelo menos dois veículos, mas para isso ser vantajoso teria que ganhar mais do que os mesmos $R \$ 11,00$. Foi a partir dessa intervenção, ao que parece, que os licenciandos passaram a relacionar o tempo de permanência e o preço a ser cobrado.

Entendemos que RPG compreende que a discussão acerca da situação que apresentou aos seus alunos suscitou um movimento que girava em torno da necessidade de comparar grandezas. Os próprios alunos perceberam que a análise de uma só grandeza (o preço) não poderia resolver o Problema (atrair mais os clientes que fossem permanecer por menos tempo). Dessa forma passaram a compreender a necessidade de analisar o que aconteceria com o preço de ambos os estacionamentos em função do tempo que permaneceriam. RPG parece ter proposto a mera generalização aritmética que se verificava em sua proposta inicial (voltada ao Ensino Médio) para uma 
compreensão geral da comparação entre grandezas, ou seja, para a compreensão do conceito de função.

Em seu relatório ela também indica ter sido "gratificante" ver os alunos envolvidos na proposta e que o resultado foi "surpreendente" porque os alunos teriam conseguido chegar à solução "sozinhos", indicando que Jonas deveria cobrar um valor inicial menor do que o do concorrente, mas cobrar um valor por hora adicional maior. Assim, quanto mais tempo permanecessem, mais valeria à pena procurar o concorrente. A licencianda não explicita se os termos gerais indicados são dela ou dos alunos, mas inferimos que, de modo geral, ela percebeu que os alunos compreenderam a relação entre o valor a ser pago e o tempo de permanência, atribuindo à sua proposição, desencadeada por um Problema, o adjetivo "gratificante" que remeteria à sua compreensão de sucesso.

O licenciando TLL indicou em seu relatório de estágio que realizou sua regência em uma turma do segundo ano do Ensino Médio em uma escola pública (ele não indicou no relatório se a mesma em que atuava como professor ou outra). O tema da aula foi probabilidade e proporcionalidade. O licenciando narra que os alunos não conseguiam compreender "o raciocínio" apresentado como solução de um Problema no caderno do aluno e que o professor pediu para ele auxiliar. O Problema tratava de um jogo que deveria ser disputado um sistema "melhor de cinco", ou seja, venceria aquele que primeiro vencesse três partidas. Havia um prêmio que deveria ser entregue entre os participantes. A primeira e a segunda partidas, no entanto, foram vencidas pelo jogador A e após a segunda partida a competição foi encerrada. Pergunta-se como o prêmio deveria ser dividido entre competidores.

TLL indica que o material didático apresenta a solução apontando que na terceira rodada $A$ e $B$ teriam iguais chances de vitória, ou seja, $50 \%$, mas que só haveria uma quarta rodada se essa terceira fosse vencida por B. O material então "atribui" $25 \%$ de chances de vitória para cada jogador na quarta rodada. Esse seria o ponto em que os alunos não teriam compreendido a razão de a chance de cada um ser $25 \%$ e não $50 \%$. TLL assinala que não apresentou a explicação da solução imediatamente, mas propôs o que ele caracteriza como um Problema e que "poderia fazer com que os próprios alunos compreendessem a ideia" (TLL, RES, EF): "Suponha que uma pessoa faz uma aposta 
em que ganhará um prêmio todas as vezes que lançar uma moeda para o alto e que der cara. Se der coroa ele para de jogar. O que aconteceria a cada lançamento da moeda?".

Ele indica que os alunos se dividiram nas respostas, sendo que alguns afirmaram que ele sempre teria $50 \%$ de chances de ganhar o prêmio e outros que disseram que a chance ia diminuindo conforme iam aumentando as jogadas. TLL indica que foi ele mesmo quem resolveu na lousa. Ele indica que simulava o lançamento de uma moeda e que ia registrando na lousa. Na primeira jogada, de fato, ele teria $50 \%$ de chances de vitória. Mas só iria para a segunda caso acontecesse os $50 \%$ de chance de dar cara. $\mathrm{Na}$ segunda rodada ele teria $50 \%$ de chances em relação aos $50 \%$ iniciais, ou seja, $25 \%$. Segundo o licenciando, os alunos compreenderam e puderam retomar o Problema original e resolver as outras situações propostas.

Entendemos que TLL possuía sentidos pessoais iniciais fortemente ligados a uma formação que, no contexto da Teoria das Situações Didáticas (BROUSSEAU, 2008), compreendia que a cada situação corresponde um Problema, conforme as indicações de TLL (RES, PEF), apresentadas no subcapítulo 4.1. Esse Problema deveria "fazer sentido" para o aluno de modo que este conseguisse compreender o conceito a partir da solução. É nesse contexto que tanto o Problema apresentado pelo licenciando na primeira regência, quanto nesta última realizada após nosso experimento formativo, trataram de situações, segundo nossa análise, com boa possibilidade de suscitarem nos alunos necessidades relacionadas aos conceitos a serem estudados, mas foram apenas apresentadas aos alunos, sendo resolvidas pelo próprio TLL. Em sua percepção, ao que parece, se o aluno consegue compreender a solução para o Problema, mesmo que apresentada por outra pessoa, ele se apropriaria do conceito envolvido na solução.

Apesar de a essência de seu sentido pessoal sobre o papel dos Problemas, aparentemente, não ter se alterado a ponto de retirar dele próprio o movimento de solucionar o Problema apenas apresentando o raciocínio envolvido (pronto) aos alunos, ele apresenta indícios de um movimento dos sentidos sobre outros aspectos, como a superação de Problemas prontos dos materiais didáticos. Em alguns momentos de seu relato TLL indica que consideraria inadequado que o material didático apresentasse a solução para o Problema proposto, e que sua proposta visava fazer os alunos pensarem na solução por si mesmos, todavia ele mesmo também o fez. Além disso, não parece que 
a situação narrada como regência tenha se originado de um movimento planejado. A narrativa do licenciando parece indicar que, ao contrário, durante uma aula regular proposta pelo professor e seguindo o material didático, diante de uma dúvida pontual dos alunos, o professor-supervisor convidou o licenciando a esclarecer a dúvida e ele considerou que essa intervenção seria a regência. De todo modo, o relato da regência que TLL apresentou não nos dá subsídio suficiente para indicar alguma aproximação entre o que classifica como Problema e o conceito que, no contexto da THC, remete ao PDA.

Já do relatório de estágio de ISC surge uma adaptação da proposta que nós realizamos durante o experimento formativo, que foi o Jogo da Adivinhação. Segundo o licenciando, após jogarem da maneira como havíamos proposto, surgiu a necessidade de os alunos resolverem equações que tivessem incógnitas em ambos os membros. Mesmo tendo conseguido se apropriar da estratégia vencedora em ocasiões com incógnitas em um dos membros, e utilizado a mesma estratégia para resolver equações escritas (sem usar as caixinhas) os alunos sentiam dificuldade para solucionar equações em que ambos os membros apareciam incógnitas. Para resolver esse "problema" - termo utilizado por ISC - ele retomou o uso de caixinhas e adaptou a proposta inspirado na proposta de balanças presentes no material didático que remete à igualdade. Ele indicou que as duplas deveriam posicionar as caixinhas sobre duas carteiras (mesas) diferentes (as próprias carteiras dos alunos). Já estava estabelecido que a quantidade de palitos dentro de cada caixinha que fosse vista seria sempre a mesma (para remeter ao valor da incógnita), e ele complementou a regra estabelecendo a quantidade total de palitos sobre cada carteira seria também a mesma (para estabelecer a igualdade). Assim, os alunos poderiam simular com as caixinhas cada membro da equação.

Claramente a adaptação de ISC mostra-se, de fato, adequada à necessidade de aprendizagem que se apresentou a ele. Ele não se manteve na situação original, mas, mantendo o mesmo Problema (descobrir a quantidade de palitos ocultos em cada caixinha) adaptou a situação para que os alunos pudessem adaptar também a estratégia. Essa adaptação parece remeter ao entendimento de que o jogo deve suscitar possibilidade de colocar o aluno em atividade a partir do Problema que se apresenta. No caso, a adaptação cumpriu dois papeis: um relacionado ao Problema do professor que 
se viu diante de uma dificuldade que a situação original não possibilitava resolver; outra em relação aos alunos, pois possibilitou que os alunos experimentassem uma situação em que deveriam pensar no conceito de igualdade de uma maneira mais profunda do que vinham fazendo até então.

Os sentidos pessoais iniciais de ISC, no início da etapa exploratória préexperimento formativo, indicavam uma compreensão de que os Problemas teriam caráter de aplicação do conteúdo ensinado e que deveriam, por isso, remeter à "realidade" (ISC, TAI-E1, PEF). Todavia, nos dois semestres e no decorrer do curso, ISC apresentou indícios de um movimento dos sentidos de modo que suas propostas de regência não giraram em torno de aplicações dos conteúdos a serem ensinados. Ainda que, na proposta do primeiro semestre ele tenha indicado no relatório de regência que fez uma intervenção para mostrar como deveria ser realizada certa etapa do procedimento, entendemos que seja significativo que após o experimento formativo, ao invés de tomar para si a demanda de "explicar como fazer", apresentando o que ele próprio caracteriza como "receita", ele adaptou uma situação conhecida para suscitar a necessidade de pensar a respeito da solução.

Por fim, MGO apresentou sua proposta de regência para uma aula de geometria. O público também foram os alunos do primeiro ano do Ensino Médio na modalidade EJA. A fim de tratar do comprimento da circunferência, ele apresentou aos alunos duas imagens da largada de duas provas de atletismo, a de 100 e a de 400 metros. O texto que acompanhava a imagem apresentava curiosidades das modalidades. O Problema era uma provocação para os alunos que deveriam discutir e responder se a configuração de largada das provas era justa ou se privilegiava algum dos competidores.

MGO narra que após alguns minutos de discussão a maioria dos alunos afirmava que nos 100 metros a configuração de largada era justa (apresentava equidade entre os participantes) mas nos 400 metros "não era muito justa porque alguns largavam muito na frente" (MGO, RES, EF). Após uma discussão - que incluía aspectos sobre ética e sobre meritocracia, em que alunos entendiam que os atletas "da frente" deviam ter feito alguma coisa antes para merecerem estar mais à frente), MGO diz que pediu para deixar o Problema um pouco de lado e entregou para eles alguns objetos circulares e barbante 
que tinham o propósito de medir e registrar o cumprimento da circunferência. Os objetos, propositalmente, tinham diâmetros diferentes.

O licenciando indica que os alunos, antes mesmo de medir e registrar os comprimentos de todos os objetos, retomaram por conta própria o Problema, revisando suas considerações iniciais para indicar que as "pistas" (na verdade, as raias) mais distantes eram "maiores" então os atletas colocados nelas teriam que ficar mais à frente para compensar. Com isso eles teriam que ficar mais à frente. Os alunos concluem junto com MGO que a matemática "ajuda o atletismo a ser justo" (MGO, RES, EF).

Os sentidos pessoais iniciais de MGO indicavam, a princípio, conforme subcapítulo 4.1, que o Problema deveria ser uma aplicação do conteúdo na "realidade", principalmente por sua afinidade com a EJA em que o que estudam tem relação direta com o mundo ou as oportunidades de trabalho (MGO, TAI-E1, PEF). Na regência, sobretudo a realizada após o experimento formativo, os sentidos de MGO sobre Problema parecem estar convergindo para uma inversão de ordem, ou seja, ao invés de o que se ensina na escola servir de aplicação na "realidade", seria a "realidade" que suscitaria as situações que ele poderia propor em sala de aula a fim de promover a aprendizagem de seus alunos.

Esse foi o movimento que pudemos acompanhar dos sete licenciandos, a partir da análise do que foi registrado nos relatórios de regência. Apresentamos, a seguir uma síntese deste isolado.

\subsubsection{Síntese do isolado C}

Neste isolado pudemos acompanhar o movimento em que percebemos as relações entre um significado social de Problema, objeto de um processo de significação pautado nos pressupostos teóricos da THC, em que este se caracteriza como essência da situação desencadeadora de aprendizagem, e o movimento dos sentidos pessoais dos licenciandos que passam a compreender seu papel nas práticas docentes como sendo, também, elemento que suscita as necessidades que geram motivos e possibilitam que os sujeitos entrem em atividade.

Nesse contexto relacionamos o PDA como elemento mediador entre a SDA e o movimento histórico-lógico do conceito, de modo que os sentidos pessoais dos 
licenciandos, ao convergirem para este significado social de PDA, superam a mera aplicação de conteúdos no cotidiano e passam a estar voltados à organização da AOE. Buscamos esboçar, na figura 16 essa compreensão: 
Figura 16: Síntese do isolado C

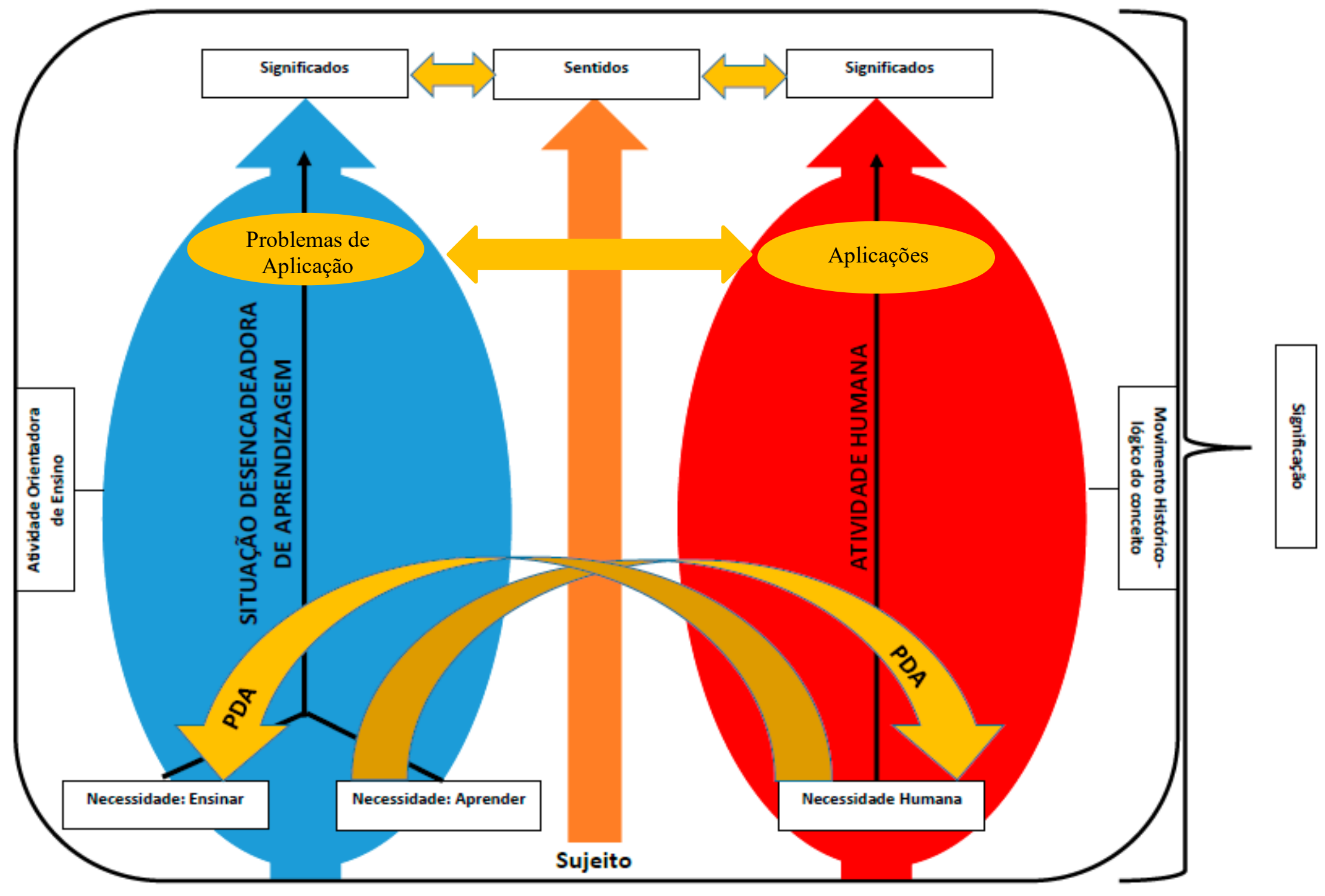

Fonte: Elaborado pelo autor. 
O movimento de alteração de sentidos dos licenciandos sobre o papel dos Problemas parece ter indicado que, para seis dos sete sujeitos cujos dados analisamos, o Problema pode ser compreendido como elemento particular que realiza a mediação entre o movimento histórico-lógico, universal no contexto da produção humana, e a situação desencadeadora de aprendizagem, singular no contexto da AOE.

A figura 16 indica que, em um contexto ontogenético, é na $A O E$ que se verifica o movimento histórico-lógico dos conceitos. Esse movimento histórico-lógico, na perspectiva do desenvolvimento filogenético, é desencadeado pelas necessidades humanas que colocam os sujeitos em atividade transformadora da natureza - o trabalho - e modificam dialeticamente a própria natureza humana. É nesse contexto que ocorre a significação, de acordo com a concepção de Leontiev (1978). O PDA é o elemento mediador entre essas necessidades históricas humanas $\mathrm{e}$ as necessidades que suscitarão nas SDA o movimento característico da AOE.

O movimento dos sentidos pessoais de seis licenciandos sobre o papel do Problema na organização do ensino, indica a superação de uma compreensão que parte de uma premissa lógico-formal do Problema e constitui um novo sentido em que o Problema é reconhecido como elemento mediador na AOE. O Problema é, portanto, o elemento que relaciona as necessidades humanas do movimento histórico-lógico às necessidades de ensinar - do professor - e de aprender - do aluno - na AOE e é isso que o caracteriza como Problema Desencadeador de Aprendizagem. Na figura 16, que sintetiza esse isolado, buscamos explicitar onde, nas práticas pedagógicas, situam-se o Problema reconhecido como PDA e seu papel de mediação na apropriação do conhecimento historicamente produzido pela humanidade, e o Problema que objetiva aplicar aquilo de que o estudante já se apropriou em situações cotidianas.

Enfim, o movimento dos sentidos, a partir dos dados coletados no experimento formativo, intencionalmente planejado para colocar os licenciandos diante da necessidade de planejar suas regências de estágio supervisionado mediadas por Problemas, remetem à superação do Problema como recurso de aplicação de conteúdos no cotidiano, de avaliação (provas, vestibulares, concursos) ou como fins em si mesmos para convergirem para um significado social, produzido no contexto da perspectiva histórico-cultural, em que o Problema é mediador entre a atividade humana e a atividade 
orientadora de ensino, constituindo-se como essência da situação desencadeadora de aprendizagem. 
CONCLUSÕES 


\section{CONCLUSÕES}

A necessidade que nos colocou em movimento e que permitiu a objetivação dos resultados apresentados neste texto diz respeito à formação inicial de professores de matemática no contexto de um discurso recorrente que elegia os Problemas como elementos fundamentais para as práticas docentes, mas que, de modo geral, não promovia nenhuma formação específica sobre o papel do Problema na organização do ensino de matemática. Nossos sentidos pessoais, fundamentados em nossa própria formação e na experiência como professor da licenciatura de matemática, apontavam para uma contradição que privilegiava o saber matemático, como fim em si mesmo, em detrimento da formação que pudesse proporcionar a aprendizagem da docência com a mesma intensidade que buscava proporcionar o saber matemático.

A princípio, buscamos nos estudos históricos, tanto na história da educação quanto na história da própria matemática, uma compreensão que nos permitisse caminhar em direção à superação dessa contradição. No percurso buscamos referenciais teóricos e metodológicos que nos permitissem tanto promover uma formação em que os licenciandos pudessem, de fato, aprender a serem professores de matemática, mais do que serem matemáticos. Entendíamos que o discurso sobre a importância do Problema nas aulas de matemática poderia contribuir substancialmente para tal intuito. Foi nesse contexto que a Teoria Histórico-cultural e a Teoria da Atividade foram reconhecidas como potenciais aportes teórico-metodológicos tanto para a formação que pretendíamos proporcionar quanto para a análise do movimento formativo e de seus resultados.

$\mathrm{Na}$ essência, a partir do reconhecimento de que a humanidade do homem não decorre de sua constituição biológica, mas da relação dialética entre biológico e cultural, com predominância deste último no desenvolvimento da espécie, propusemos um experimento formativo pautado na compreensão de que o professor também não se torna professor exclusivamente pelo domínio do conteúdo a ser ensinado, mas também pela relação dialética que deve ser capaz de estabelecer entre aquilo que sabe e como ensina, o que, por sua vez, também se relaciona com as formas pelas quais seus alunos aprendem e o que eles aprendem. É na unidade dialética entre esse ensinar e aprender que a atividade orientadora de ensino se apresentou a nós como chave para o movimento formativo que pretendíamos. 
Ao defender que as necessidades originam os problemas que motivam a humanidade a buscar soluções no contexto da atividade, Leontiev (1978) torna-se um referencial para a constituição, no contexto escolar, do movimento que compreende que o movimento histórico-lógico da humanidade deve subsidiar a busca pela satisfação da necessidade de ensinar, por parte do professor, e de aprender, por parte do aluno. Essa é a proposta da atividade orientadora de ensino (MOURA, 1996; 2002).

Nesse contexto da $\mathrm{AOE}$, em relação aos estudos voltados ao ensino e à aprendizagem de matemática, o problema que desencadeia a atividade humana que culmina na produção social do conhecimento deveria suscitar, analogamente, Problemas que pudessem suscitar nos sujeitos necessidades de apropriação de conceitos que, por sua vez, satisfizessem as necessidades de ensinar e de aprender. Moura e Lanner Moura (1998) indicam que a atividade orientadora de ensino remete à proposição de uma situação. Esta situação remete à singularidade do movimento universal histórico-lógico e como pretende possibilitar o ensino e desenvolver a aprendizagem, constitui-se como situação desencadeadora de aprendizagem - SDA.

A essência da SDA é o problema que relaciona as necessidades de ensinar e de aprender da AOE à necessidade humana que está na gênese do movimento históricológico universal de produção, que remete à significação dos conceitos a serem estudados no contexto singular da educação escolar. Esse Problema, impregnado das necessidades humanas que possibilitam colocar o sujeito em atividade no contexto da AOE, é o Problema Desencadeador de Aprendizagem.

Dessa forma, o PDA, não se resume aos Problemas apresentados aos alunos dos cursos de licenciatura como mera reprodução dos conteúdos estudados que tendem a ser tomados como modelos a serem reproduzidos posteriormente nas práticas profissionais desses licenciandos quando assumirem a docência. Também não é apenas o Problema voltado à aferição de conteúdos supostamente aprendidos ou, tão pouco, a questão que visa exercitar técnicas de cálculo ou aplicação mecânica de propriedades ou definições.

Assim, nossa necessidade de ensinar aos licenciandos a serem professores e a necessidade deles de aprenderem a serem professores possibilitou que entrássemos em atividade. Nessa atividade o problema sobre como os licenciandos compreendiam o que 
seria um Problema e qual seria seu papel nas práticas docentes foi o que desencadeou o nosso próprio movimento e deu contexto ao nosso experimento formativo.

Os Problemas tradicionalmente apresentados aos licenciandos, seja durante a educação básica ou durante a própria graduação, que remetem, de modo geral, à aplicação do que já foi ensinado em situações diversas, tendem à reprodução de métodos e técnicas de ensino modelares. Essa compreensão pode ser resumida em um sentido, manifestado no senso comum, que entende que o professor na graduação deva ensinar uma matemática complexa e que métodos e concepções didáticas seriam objetivados pela observação de suas práticas. Nessa concepção o professor da graduação seria modelo e apresentaria modelos. As práticas originadas nessa "corrente" vão constituindo uma matemática mecanicamente reproduzida que pode estar relacionada a índices elevados do que se costuma chamar de "fracasso escolar". Isso porque, se o aluno não consegue reproduzir adequadamente aquilo que seu modelo já consegue fazer, seja na graduação ou na educação básica, o ensino, de modo geral, recebe rótulos (reprovação, fracasso, etc.).

De fato, no início de nosso experimento formativo, em que analisamos o movimento dos sentidos de sete alunos do curso de licenciatura em matemática, os sentidos pessoais iniciais tendiam a reconhecer que o papel do Problema seria colocar o diante da necessidade de aplicar o que já havia sido apresentado a ele, segundo um ferramental técnico pronto. Nos propusemos, então, a investigar o movimento desses sentidos pessoais tentando encontrar indícios de que estes pudessem convergir para um entendimento que se aproximasse do significado social de PDA, como apresentamos.

Em um primeiro momento, no entanto, só pudemos realizar uma formação voltada aos estudos que, na verdade, apresentaram aos licenciandos aspectos diversos sobre 0 papel do Problema em sala de aula, segundo pesquisadores que se dedicam ao tema, bem como apresentar (também modelarmente, como verificamos posteriormente) Situações Desencadeadoras de Aprendizagem prontas, na expectativa de que os licenciandos elaborassem eles próprios o que, àquela altura, entendíamos como "PDA". O movimento, possivelmente pela aproximação com um método modelar que criticamos aqui, apenas contribuiu para auferirmos sentidos pessoais iniciais dos licenciandos, de 
modo que pudemos, a partir daquele movimento inicial, definir os participantes que teriam seu movimento formativo analisados durante o experimento formativo.

Já durante o experimento formativo, uma importante ação no sentido de não tomarmos para nós a apresentação de situações prontas remeteu a um olhar diverso sobre a História da matemática, de modo que possibilitamos que os licenciandos percorressem os próprios caminhos, tendo como parâmetro a necessidade de planejamento da regência de estágio. Todos os sete licenciandos já haviam participado da disciplina regular da matriz curricular em que se propunha os estudos de HM. Todavia, entendemos que tais estudos remetiam a estudos que chamamos de "contação de histórias", em que aspectos geográfico-cronológicos se sobrepunham à compreensão da matemática como produção humana e retirava de foco o aspecto de "porque foi feito" para privilegiar a narração sobre como fazer. É verdade que tal perspectiva não tem sua gênese nas licenciaturas em matemática. É relativamente comum que livros e produções que se propõem a tratar da HM apresentem aspectos relacionados a datas e cálculos desenvolvidos ao longo do tempo. Na licenciatura em matemática, no entanto, para que o PDA possa mediar a relação dialética entre produção humana e atividade orientadora de ensino, verificamos que a HM precisaria superar a apresentação cronológica de fatos históricos e se concretizar como o que chamamos de História da Matemática Conceitual. Nesse contexto, os estudos de HM voltam-se à busca das necessidades que, historicamente, desencadearam o movimento histórico-lógico de produção e que podem subsidiar a elaboração de Problemas que possam desencadear um movimento análogo, no contexto da apresentação de situações desencadeadoras de aprendizagem.

Aliar os estudos de uma História da Matemática Conceitual com a proposição de SDA elaboradas por nós mesmos ou por pesquisadores da teoria da atividade, para que os estudantes não apenas solucionassem, mas também analisaram quanto ao seu papel na organização do ensino, permitiu que percebêssemos os licenciandos em um movimento que apontava uma contradição entre sentidos que admitiam o Problema como recurso de aplicação e uma compreensão diferente em que o Problema fosse desencadeador de aprendizagem. Foi esse o contexto que produziu o movimento dos sentidos pessoais dos licenciandos que acompanhamos. 
Os resultados gerais indicam que as relações entre um significado social de Problema, produzido no contexto da THC e da teoria da atividade, e os sentidos pessoais iniciais dos alunos da licenciatura, diante da necessidade de planejar a regência de estágio utilizando Problemas, deram início a um movimento no qual verificamos indícios de constituição de novos sentidos pessoais sobre o papel do Problema na organização do ensino. Nossa análise buscou acompanhar o movimento de modo que fosse possível compreender o fenômeno da formação a partir desse movimento dos sentidos pessoais. Foram realizados dezenove encontros em que se promovia a formação de todos os licenciandos matriculados nas disciplinas de Prática de Ensino da matriz curricular do curso. Na pesquisa destacamos a análise os dados, coletados naquele contexto formativo, sobre o movimento de sete licenciandos, para os quais pudemos perceber, em etapa anterior ao experimento formativo, indícios de sentidos iniciais sobre o papel do Problema em sala de aula.

A licencianda JZM compreendia inicialmente que o Problema assumiria o papel de desafiar os alunos a resolver situações a partir daquilo que o professor estivesse ensinando e como uma forma de "dar uma aula diferente", em referência à possibilidade de incorporar o aspecto lúdico às aulas. Ela compreendia que o Problema seria diferente da mera resolução de questões, pois indicaria também quando a "matéria" seria aplicada no dia-a-dia. A licencianda participou das situações propostas durante o experimento formativo de modo que verificamos indícios de que, no debate com os demais colegas, ela passou a reconhecer q importância da HM no planejamento de situações desencadeadoras de aprendizagem, chegando a concordar que as SDA poderiam colocar o aluno em atividade de aprendizagem, segundo nossa conclusão, como se ele fosse "um personagem" da própria história da matemática.

Nesse contexto ela planejou e executou sua regência utilizando uma SDA materializada no contexto de um jogo. Ela referenciou a relação entre a $\mathrm{HM} \mathrm{e} \mathrm{a}$ necessidade que queria suscitar a partir do jogo, foi crítica em relação à opção da professora-supervisora de estágio da escola onde realizou a regência em razão de não ter podido realizar sua proposta da maneira como considerava ideal, ou seja, como introdução do conceito, que remetia ao referencial cartesiano e indicou aspectos do ato de jogar dos alunos que poderiam desencadear aprendizagens de conceitos que ainda 
seriam estudados. Percebemos indícios de alteração de sentido da licencianda sobre o papel do Problema, presente no jogo que ela apresentou, já desde a compreensão de que o próprio jogo possua um Problema e que este seja desencadeador de aprendizagem, de modo a superar a mera aplicabilidade de lições ensinadas previamente.

RPG entendia que o Problema deveria ser apresentado aos alunos antes de o professor "explicar" o conteúdo. De acordo com aquele sentido pessoal inicial, depois de apresentado o Problema, o professor deveria ir fazendo perguntas diretivas para que seus alunos pudessem encontrar uma solução. Em suas palavras "o Problema serve como desafio inicial para despertar o interesse dos alunos pela matéria". Durante 0 experimento este indício de sentido pessoal inicial foi cada vez mais, a nosso juízo, revelando uma compreensão sobre a importância da realidade. Inicialmente, no entanto, a realidade era compreendida como meio de aplicação pragmática daquilo que o professor ensinasse, como se RPG estivesse se preparando o tempo todo para responder ao seu aluno a pergunta "para que serve isso?".

Durante o experimento ela (e os integrantes do grupo em que participou) propuseram, em uma proposta específica, a utilização do que consideravam um Problema no contexto de uma aula sobre Juros simples. O Problema em questão, no entanto, produziu um movimento que colocou em debate justamente essa compreensão sobre o Problema ser aplicação de lições já ensinadas, pois o contexto da atividade pretendia a proposição de situações que pudessem ensinar um conceito novo. A discussão promovida a partir dessa proposição parece ter sido particularmente importante no movimento formativo de RPG. Ela pareceu admitir que se o Problema suscita a necessidade histórica do conceito, aquilo que ela caracterizava como "realidade", que poderia ser compreendido como o cotidiano, teria outro papel no processo de organização das práticas docentes. Não seria mais meio para aplicação das lições já ensinadas, mas fonte capaz de suscitar as necessidades que poderiam promover a aprendizagem de algo novo.

Foi assim, entendemos, que ela propôs uma regência em que adota um Problema inspirado (mas distinto) no que já havia indicado naquele primeiro momento de trabalho. Mas ao contrário daquele em que todas os dados para a resolução estavam disponíveis 
no próprio enunciado, agora RPG propunha que os licenciandos analisassem uma situação que bem poderia fazer parte de qualquer cotidiano e suscitar uma análise (e não uma resposta direta). Seu Problema coloca os alunos diante da necessidade de comparar grandezas distintas e é apresentado no contexto do estudo das funções. A licencianda cita em seu relatório os estudos sobre a HM sobre o conceito de função que realizamos durante a formação, o que constitui para nós um importante indício de que a necessidade que ela buscou suscitar com a situação que propôs, que possuía um Problema, de fato impregnado da mesma necessidade histórica que levou a humanidade a desenvolver o que hoje reconhecemos como o conceito de função, foram relevantes no que parece ser uma mudança de uma compreensão em que se ensina para aplicar na "realidade" para passar a compreender também a realidade como fonte de necessidades para o ensino.

DFS parece ter percorrido um caminho similar ao de RPG. Colegas de grupo e fora dele, a maioria dos estudos realizados durante o experimento formativo, contava com a participação conjunta de ambas. DFS também entendia que o Problema deveria tratar da "matéria" que estivesse sendo estudada e que esta deveria ser direcionada a resolver problemas do dia-a-dia. Distinguia questões de cálculo (exercícios) de Problemas, sendo que estes deveriam ser apresentados em um contexto (uma narrativa) que pudesse ser resolvida aplicando os temas da matéria.

Ela também, tudo indica, teve sua trajetória marcada a partir da proposição do Problema na situação que visava um planejamento para o ensino de Juros Simples. A princípio, ao que parece, ela sentiu-se desconfortável com os "palpites" dos colegas na proposta de seu grupo. Todavia, foi percebendo que, de fato, o Problema passou a, ao menos em parte, possibilitar que os alunos pensassem a respeito do que seria ensinado, e não apenas aplicassem o que já havia sido ensinado.

A licencianda, em seu relatório de estágio, reforçou o indício de que reconheceria que o Problema que suscita necessidades históricas tem potencial para desencadear a aprendizagem. Ela utiliza um significativo espaço de seu texto para tratar dos aspectos históricos sobre o conceito que deveria ensinar durante a regência, que também era o conceito de função. E ela propõe trabalhar o conceito a partir de um jogo. Reconhecemos que, de fato, o jogo proposto seria uma situação desencadeadora de aprendizagem, em 
que a licencianda propõe um Problema que envolve o controle de grandezas distintas, remetendo à possibilidade de desencadear a aprendizagem do conceito de função.

Para PNL também, inicialmente, o Problema deveria remeter a situações da realidade e ajudar os alunos a estar preparados para resolver os problemas de avaliações como concursos e vestibular. A função da escola como potencial fornecedora de mãode-obra para o mercado de trabalho parecia permear o discurso de PNL, que não se reconhecia como professora em formação, mas sim como estudante de um curso de matemática (entendida como um fim em si mesma).

PNL deu indícios de um reconhecimento do papel do Problema nas aulas de matemática que, para nós, parece remeter a uma essencialidade na organização da atividade pedagógica. Percebemos indícios de que a licencianda compreendia que o Problema seria recurso de aplicação de definições, propriedades ou algoritmos, mas que isso, de alguma forma, não satisfazia suas próprias necessidades, o que (sem prejuízo de outras razões) contribuía para afastá-la da docência. Verificamos que, no contexto do experimento formativo que realizamos que, mais uma vez, pretendia, como pano de fundo, coloca-los diante da necessidade de planejar a regência de estágio, PNL colocouse em um movimento em que o Problema teria passado a desempenhar o papel de desencadeador de aprendizagem. É possível, pelo que inferimos do que a licencianda registra em seu relatório de estágio, por exemplo, que a aprendizagem sobre a organização da atividade pedagógica, que enfatizou a compreensão do papel do PDA na SDA, tenha contribuído para aproximar os sentidos pessoais da licencianda da efetivação do exercício da docência.

Ela realizou sua regência também adotando um jogo, a partir de um planejamento coletivo. O jogo foi o mesmo que DFS utilizou em sua regência e contribui para concluirmos que, também sobre PNL há indícios de uma alteração de sentidos a respeito do papel do Problema em sala de aula.

Já TLL possuía sentidos pessoais iniciais que entendiam que o Problema devesse ser selecionado de acordo com o conteúdo que o aluno devia aprender. Nesse contexto, o professor deveria conhecer e estar preparado para resolver uma série de Problemas similares aos que proporia aos alunos, mas que estes devem "tentar" resolver, antes, sozinhos qualquer proposta apresentada pelo professor. Essa compreensão mostrou-se 
bastante próxima à proposta da Teoria das Situações Didática (Brousseau, 2008), que o licenciando manifestou explicitamente conhecer em razão de seus estudos para realização do Trabalho de Conclusão de Curso.

O movimento de TLL no contexto de nosso experimento formativo parece remeter a alterações específicas sobre aspectos relacionados ao papel do Problema na organização do ensino, como a necessidade de superar a proposição de Problemas prontos, selecionados de materiais didáticos disponíveis e o reconhecimento da importância da intencionalidade e dos motivos do professor na organização do ensino, para além da relevância do conteúdo matemático a ser aplicado na solução de um Problema de aplicação direta. Entendemos que ele apresentou propostas que, de fato, poderiam desencadear a aprendizagem dos alunos, mas em ambas as regências de estágio que relatou, foi ele próprio quem resolveu as situações propostas, como que apresentando um modelo a ser seguido pelos alunos. Isso seria, a nosso juízo, um reforço da compreensão de que o professor deveria conhecer e estar preparado para resolver uma série de Problemas similares aos que proporia aos alunos. De acordo com esse sentido inicial, o aluno poderia aprender da mesma forma se resolvesse ele próprio o Problema ou se visse alguém mais experiente resolvendo. $O$ importante seria conhecer o máximo possível de situações em que se pudesse aplicar técnicas parecidas para se chegar a resultados similares.

O movimento dos sentidos de TLL, segundo os indícios que destacamos na pesquisa, apesar do reconhecimento de alguns aspectos que consideramos que deveriam ser objetivados, não indicou uma superação da apresentação de soluções para os alunos. Seu sentido pessoal pareceu permanecer vinculado à ênfase na importância de se conhecer uma solução, pois esta estaria impregnada do conceito a ser ensinado, e não nas necessidades suscitadas pelo Problema. Com isso, deixar o aluno resolver sozinho ou resolver para ele ver seriam a mesma coisa, na concepção que podemos verificar nas considerações de TLL, de modo que a apresentação da resposta esperada para o Problema seria mais relevante do que o processo de resolução e o desenvolvimento dele decorrente.

O licenciando ISC indicava durante o primeiro semestre que os Problemas deveriam ter caráter de aplicação do conteúdo ensinado e entendia que poderia 
caracterizar Problemas como sendo situações que remetessem à "realidade". No entanto, já no final daquele primeiro movimento formativo, o licenciando realizou sua regência abordando uma concepção de Problema distinta da mera aplicabilidade de conceitos ensinados e já mais próxima de uma compreensão de que o papel do Problema nas aulas de matemática remetesse à possibilidade de desencadear a aprendizagem.

Desse modo, ISC foi o único dos sete licenciandos que iniciaram nosso experimento formativo, no segundo semestre daquele ano, manifestando indícios de sentidos pessoais sobre o Problema que superavam uma concepção pragmática e se aproximavam de uma perspectiva histórico-cultural.

Naquele primeiro semestre, ISC organizou sua regência pretendendo ensinar frações a partir de uma situação que envolveu a história do conceito. A partir daquela proposta, o licenciando pôde, segundo seu próprio relato, aproximar-se da compreensão de denominador comum e fração equivalente e operações com frações. Ele indica que os alunos que participaram da situação já conheciam, dos estudos nas séries iniciais, alguns aspectos relacionados às frações, mas que, a nosso entender, diziam respeito à aparência do conceito, em que precisariam apenas contar partes e todo para representar mecanicamente as frações. A partir de sua regência os alunos puderam compreender a necessidade de fracionar o todo e obter formas diferentes de medição em um movimento que simula o desenvolvimento histórico do conceito, conforme indica Caraça (1989).

Nos encontros do experimento formativo, ISC indicou reconhecer aspectos de uma história da matemática conceitual como relevantes à organização da atividade pedagógica, além de uma caracterização de Problema que se aproximada do que compreendemos como PDA. No debate sobre uma das situações que propusemos, o Problema de João Napião, por exemplo, ISC foi o licenciando que indicou primeiro que o papel da história da matemática havia sido importante na elaboração da situação e no surgimento do PDA, além de reconhecer que o Problema colocava o aluno diante da necessidade de encontrar o expoente de uma potência que remete à definição de logaritmos.

Em sua regência relacionada ao experimento formativo, ISC ratificou este entendimento ao relatar que adaptou uma das situações que propusemos aos licenciandos em um dos encontros para que pudesse responder adequadamente a uma 
demanda surgida com seus alunos (de resolver equações em que aparecem representações de incógnitas em ambos os membros de uma equação). Ele fez uso dos recursos que tinha disponíveis (carteiras) e inspirou-se na proposta contida no material didático da escola (na verdade, da rede pública) para suscitar a necessidade de refletir sobre a ideia de igualdade, que é essencial para a resolução de equações.

Entendemos que os sentidos de ISC sobre o papel do Problema foi se alterando já durante a formação que propusemos durante o primeiro semestre, e que durante o experimento formativo propriamente dito, tais sentidos foram sendo ratificados $e$ convergindo cada vez mais para uma compreensão do Problema como elemento desencadeador de aprendizagem na atividade pedagógica.

Por sua vez, o licenciando MGO, que também já tinha realizado no primeiro semestre uma situação desencadeadora de aprendizagem, que continha um PDA relacionado à necessidade de compreensão do conceito de equações, afirmava inicialmente, ao que tudo indica, fortemente influenciado por sua atuação como professor da Educação de Jovens e Adultos, que o Problema deveria ser uma aplicação do conteúdo na "realidade", principalmente em relação ao mundo do trabalho, como preparação de todos para o mercado de trabalho e o mundo profissional, como a realização de concursos.

Apesar de ter realizado uma situação desencadeadora de aprendizagem já no final daquele semestre que subsidiou nossa interpretação sobre os sentidos pessoais iniciais dos licenciandos sobre o papel do Problema, não podemos afirmar que tal opção durante a regência, por si só, tenha decorrido de uma apropriação sobre o conceito de SDA ou de PDA, já que é possível que, naquele momento, o licenciando tenha meramente reproduzido uma situação que havíamos realizado durante as aulas e que ele, talvez, tenha reconhecido como potencialmente lúdica e adequada para o que deveria fazer.

No entanto, no decorrer do experimento formativo, MGO foi manifestando indícios de um reconhecimento do papel da HM na organização da atividade pedagógica. Foi ele quem indicou que, diante da dúvida sobre se o professor ou algum colega deveriam ou não apresentar uma estratégia vencedora durante um jogo (ou algum aspecto da solução de um problema), aquela "dica" dependeria da "vontade" do aluno para encontrar uma resposta. Naquele contexto, pudemos inferir que a indicação de MGO ao adotar o termo 
"vontade" poderia ser relacionada com o que definimos, no contexto da teoria da atividade, como motivo. Daquele modo, motivo (ou vontade, nas palavras do licenciando) e objeto (a estratégia, naquele caso) coincidiriam e o aluno poderia se apropriar da essência do conceito presente na estratégia de solução, mas em sua própria atividade, apesar da participação do outro (num movimento que poderia, por sua vez, ser reconhecido, em diversos aspectos, como mediação).

Em sua regência de estágio supervisionado, no final do experimento formativo, MGO indicou que utilizou um Problema que visava colocar os seus alunos diante da necessidade de refletir sobre o comprimento da circunferência. Ele trouxe uma situação emergente da realidade que potencializava uma discussão em torno de uma aparente contradição. A partir de sua proposta, além de outros debates interdisciplinares, 0 licenciando os alunos foram, de fato, a pensar sobre o comprimento da circunferência e estabelecer uma conclusão que os levou a reconsiderar suas posições iniciais sobre o que fora proposto no Problema.

Com isso, pudemos inferir que o licenciando também realizou um movimento que parece indicar alterações em seu sentido pessoal inicial sobre o papel do Problema em suas aulas, partindo de uma visão pragmática, voltada ao mercado de trabalho, e convergindo para um significado social de Problema como elemento desencadeador de aprendizagem, no contexto das teorias da atividade e THC, de modo que a "realidade" do trabalho e do cotidiano teriam deixado de ser somente meio para aplicação do que foi ensinado e passado a ser também fonte de necessidades relacionadas à apropriação dos conceitos a serem ensinados, também na Educação de Jovens e Adultos.

O movimento dos sentidos pessoais dos licenciandos destacou, como indicamos nos isolados e episódios que apresentamos a partir do subcapítulo 4.2, a superação de um caráter pragmático do Problema para compreendê-lo também como elemento desencadeador de aprendizagem à medida em que suscita no sujeito a necessidade de apropriação da produção humana de conhecimento.

Essa superação se evidenciou a partir dos dados destacados nos isolados, que indicaram o movimento dos sentidos dos licenciandos convergindo para 0 reconhecimento de que a proposta de ensinar conceitos matemáticos a partir de Problemas acarreta a necessidade de que estes Problemas suscitem a necessidade de apropriação 
do conceito pelos sujeitos, o que chamamos de reconhecimento da necessidade da necessidade, e que a mera proposição de Problemas "prontos", selecionados a partir de recursos didáticos diversos, apenas potencializa a aplicabilidade e não consideraria aspectos relacionados à intencionalidade e aos motivos do próprio professor. Assim, o Problema deveria assumir o protagonismo da atividade de ensino no contexto da AOE, pois é o Problema que indica a intenção do professor e caracteriza a necessidade que ensejará motivos para colocar o estudante em atividade de aprendizagem. É também no Problema que se evidenciam os motivos do professor. Dessa forma, o Problema pode ser compreendido como protagonista da AOE e constitui a essência da Situação Desencadeadora de Aprendizagem.

Também ficou evidente a partir da análise dos dados apresentados nos isolados 0 movimento dos sentidos em relação à importância dos estudos de História da Matemática para a organização do ensino em uma perspectiva histórico-cultural. Eles passaram a reconhecer a HM como fonte reveladora da essência do conceito, dos nexos conceituais e das necessidades que levaram a humanidade a produzir os conceitos que produziu, bem como a forma como produziu, para poder, a partir desse reconhecimento, propor Problemas com potencial para serem desencadeadores de aprendizagem. Esse movimento caracterizou a superação de uma História da Matemática cronológicogeográfica, estudada durante a formação de professores, para colocar em evidência o que denominamos como História da Matemática Conceitual, conforme definimos no subcapítulo 2.3, que contribui significativamente para a aprendizagem da organização do ensino, objetivo fundamental dos cursos de licenciatura.

O movimento dos sentidos verificados nos isolados que destacamos indicou, ainda, o reconhecimento do Problema como essência da Situação Desencadeadora de Aprendizagem. A SDA é indicativa dos motivos do professor - em atividade de ensino e dos motivos dos alunos - em atividade de aprendizagem -, e possibilita que se constitua a atividade orientadora de ensino. Nessa perspectiva, a SDA estabelece o contexto, as regras, as instruções para um movimento intencionalmente planejado que visa satisfazer uma necessidade de apropriação pelo sujeito, necessidade esta que é suscitada pelo PDA, possibilitando que sejam gerados motivos e potencializando que os sujeitos entrem em atividade. 
Enfim, o movimento dos sentidos dos licenciandos sobre o papel do Problema na organização do ensino, a partir dos dados coletados no experimento formativo, intencionalmente planejado para colocar os licenciandos diante da necessidade de planejar suas regências de estágio supervisionado mediadas por Problemas, remetem à superação do Problema como recurso de aplicação de conteúdos no cotidiano, como avaliação (em provas, vestibulares, concursos) ou como fins em si mesmos para convergirem para um significado social, produzido no contexto da perspectiva históricocultural, em que o Problema é mediador entre a atividade humana e a atividade orientadora de ensino, constituindo-se como essência da situação desencadeadora de aprendizagem.

Durante a pesquisa também identificamos um movimento em nossos próprios sentidos sobre o conceito e o papel do Problema nas aulas de matemática. Ainda que não teoricamente fundamentados, iniciamos nossos estudos nessa pesquisa compreendendo que o papel do Problema, como da escola de modo geral, não poderia ser reduzido a um mero aparelhamento do capital e do mercado de trabalho. Entendíamos que formar para o exercício da cidadania não poderia se resumir a formar para o "saber fazer", mas também, e principalmente, para o desenvolvimento do pensamento crítico em favor de uma educação humanizadora.

Nossa atividade, portanto, remeteu a uma compreensão sobre os diversos modos de se promover tal formação e, de maneira especial, no reconhecimento a respeito do potencial de nosso aporte teórico e metodológico para poder alcançar essa meta. Nesse percurso, o PDA assumiu, para nós, o papel do desencadeamento da aprendizagem da docência, de modo que poderíamos dizer que o PDA é também desencadeador do ensino.

Nosso movimento passou pelo reconhecimento de nossa própria contradição ao estabelecer crítica às práticas modelares e apresentar uma proposta formativa, a princípio, modelar, na qual esperávamos que, pela mera apresentação de SDA prontas e criadas por outros, os licenciandos poderiam reconhecer o papel do Problema de maneira distinta da que vinham adotando e elaborar eles próprios suas situações desencadeadoras. Esse reconhecimento modificou o movimento para a proposição de situações que, ainda que fossem as mesmas, em alguns encontros, mudaram o objetivo 
(o motivo) para a necessidade de compreender uma forma de planejar a própria docência, e isso minimizou a importância de se resolver os Problemas propostos nas SDA, apenas, e enfatizou a relevância de os licenciandos refletirem sobre a elaboração daquelas SDA segundo a satisfação de uma necessidade: Ensinar.

Os motivos pelos quais os licenciandos tendiam a propor Problemas em suas aulas foram se modificando à medida em que eles vão se reconhecendo em uma atividade de formação docente (e não apenas de aprendizagem de um conceito matemático), de modo que, segundo os indícios que destacamos, seus sentidos pessoais sobre o papel do Problema em suas próprias práticas vão se alterando para o reconhecimento do Problema como elemento desencadeador de aprendizagem.

Em nosso caso, nosso movimento esteve fundamentado em objetivos que visavam satisfazer a necessidade de ensinar os licenciandos a pensar sobre uma forma de ensinar. $E$, nesse movimento, compreendendo aquele propósito de promover uma formação humanizadora, os sentidos dos licenciandos parecem ter sido mobilizados para o reconhecimento de que as ações do professor, incluindo aí a seleção, elaboração, adaptação e demais práticas profissionais relacionadas aos Problemas e sua resolução, precisam superar aspectos relacionados com o "treinamento" para reproduzir situações modelares, o que aproximaria o ensino da programação de uma máquina e se caracterizaria como mecânico e "não-humanizador", para convergir para uma compreensão mais próxima ao desenvolvimento do pensamento crítico a partir da mobilização de conhecimentos e no contexto do trabalho social e coletivo, buscando a satisfação das necessidades no âmbito da atividade humana. Buscamos sintetizar esse nosso movimento em uma imagem, figura 17 , a seguir. 
Figura 17: Síntese do movimento verificado na pesquisa

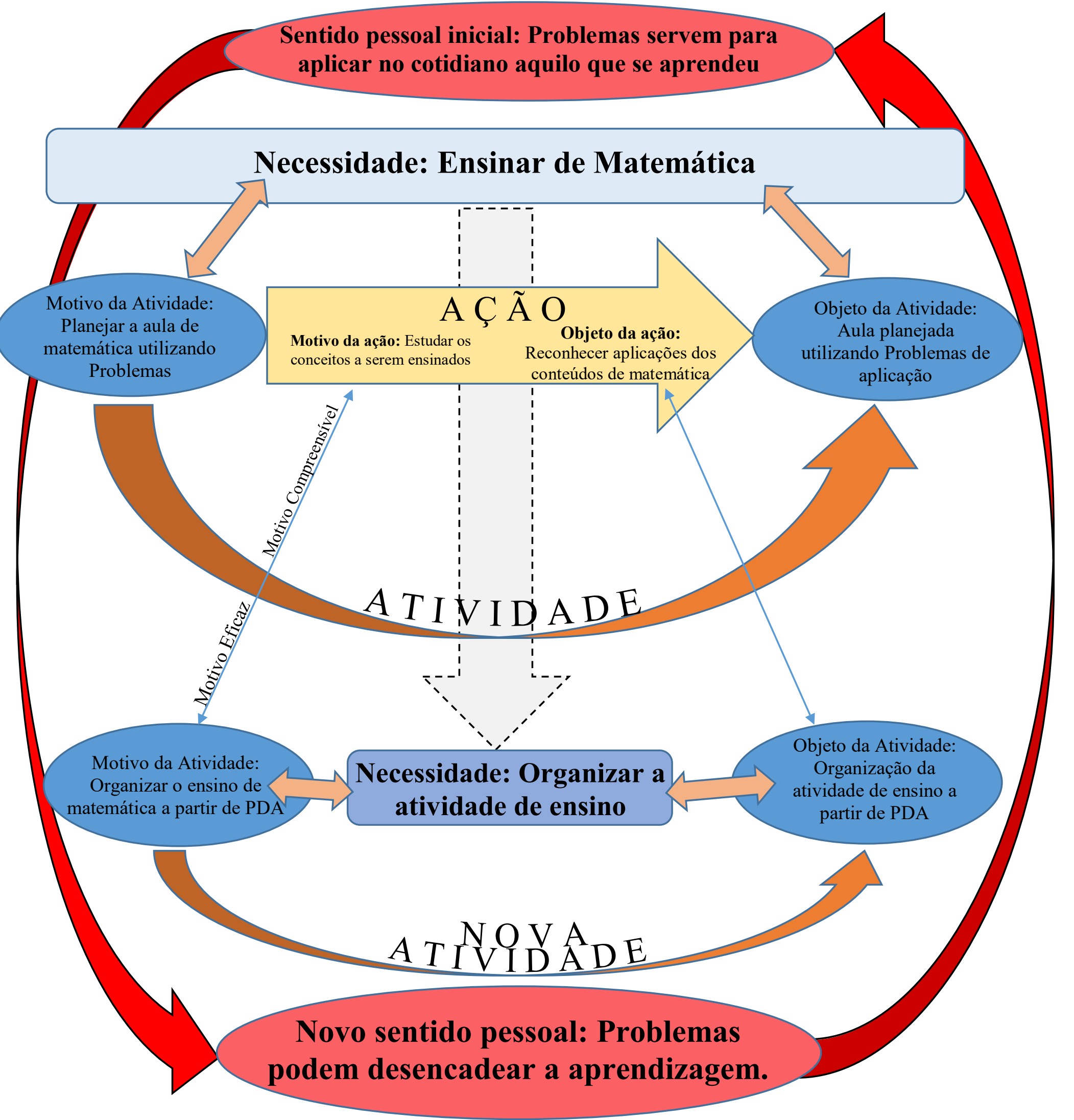

Fonte: Elaborada pelo autor 
$\mathrm{Na}$ imagem buscamos indicar o movimento em que a necessidade dos licenciandos de aprender a ensinar matemática produz os motivos sobre a organização do ensino, nos quais verificamos seus sentidos pessoais sobre Problemas, como indicara Leontiev (1978) quando afirmou que para conhecer os motivos dos sujeitos precisamos compreender seus sentidos. Os sentidos iniciais dos licenciandos, de modo geral, remetiam à compreensão de que o papel do Problema na organização do ensino seria o de recurso de aplicação daquilo que já havia sido dado previamente. Com isso, seus motivos incluíam uma organização que utilizaria Problemas que seriam aplicações daqueles conteúdos em situações cotidianas. A atividade deles se efetivaria, nesse contexto, em uma organização do ensino de modo que os conteúdos ensinados seriam aplicados em situações do dia-a-dia.

No entanto, o movimento dos sentidos iniciais dos licenciandos, que indica a convergência para o reconhecimento sobre a importância do Problema como desencadeador de aprendizagem, proporciona uma mudança de motivo da atividade. Este passa, no movimento da atividade de aprendizagem da docência, do motivo compreensível de planejar a aula utilizando Problemas - que estava ligado ao sentido de Problema como recurso de aplicação - para o motivo eficaz de organizar o ensino a partir de PDA, sendo este um conceito compreendido no âmbito da THC. Esse novo motivo coincide com a organização do ensino que satisfaz as necessidades de aprender a ensinar matemática e de organizar a atividade de ensino.

Assim, podemos concluir que os licenciandos que foram produzindo novos sentidos sobre o papel do Problema nas práticas pedagógicas estiveram em atividade de aprendizagem da docência e que, no contexto dessa atividade, o movimento de seus sentidos pessoais sobre o papel do Problema na organização do ensino de matemática convergiu para a compreensão de que o Problema é desencadeador de aprendizagem, e portanto assume papel de destaque na organização do ensino por parte dos professores, já que medeia a relação dialética entre AOE e o movimento histórico-lógico de produção do conhecimento humano.

Esse movimento dos sentidos pessoais dos licenciandos também revelou implicações para a formação de professores de matemática. A legitimação da necessidade de o Problema estar impregnado pelas necessidades que contextualizam a 
produção histórica e cultural do conhecimento pela humanidade, possibilitou reconhecer esse movimento de aprendizagem da docência, em que os licenciandos superam a adoção de Problemas "prontos", assim compreendidos aqueles que são apresentados nos materiais e demais instrumentos didáticos para mera aplicação de algum conteúdo apresentado previamente, e passam a preocupar-se com o planejamento, que denota intencionalidade e define motivos, das SDA, nas quais os Problemas assumem o protagonismo e desencadeiam o movimento que pode culminar na aprendizagem.

Enquanto aprendiam a organizar a atividade pedagógica, identificamos que o movimento dos sentidos pessoais dos licenciandos sobre o papel do Problema nas aulas se relacionava dialeticamente com os sentidos - e, consequentemente, com os motivos - sobre a própria formação de professores e sobre o papel do professor na atividade de ensino. Com isso, podemos afirmar, a partir dos resultados que evidenciamos por esta pesquisa, que a atividade de formação para a docência é aquela que visa a tomada de consciência do sujeito sobre sua condição de sujeito da atividade pedagógica, de modo que os licenciandos puderam se reconhecer, mais do que como estudantes de matemática, mas também, principalmente, como professores de matemática em formação. 
Referências 


\section{REFERÊNCIAS}

ARAUJO, E. S. Atividade Orientadora de Ensino: princípios e práticas para organização do ensino de matemática. Revista Paranaense de Educação matemática, v. 1, p. 1-24, 2018.

ASBAHR, F. S. F.; PIOTTO, D. C.; FURLANETTO, F. R. Significação e Sentido na psicologia histórico-cultural: implicações para a educação escolar. In: Manoel Oriosvaldo de Moura. (Org.). Educação escolar e pesquisa na teoria histórico-cultural. 1ed. São Paulo: Loyola, p. 42-52, 2017.

AUSUBEL, D. P. The psychology of meaningful verbal learning. New York: Grune \& Stratton; 1963.

BERNARDES, M. E. M. Mediações simbólicas na atividade pedagógica: Mediações simbólicas na atividade pedagógica contribuições do enfoque histórico-cultural para o ensino e aprendizagem. 2006. 330f. Tese (Doutorado em Educação) - Faculdade de Educação, Universidade de São Paulo, São Paulo, 2006

BOYER, C.B. História da matemática. Trad. Elza F. Gomide. São Paulo: Edgard Blücher, 1974.

BRASIL. Diretrizes Curriculares Nacionais para os Cursos de matemática, Bacharelado e Licenciatura / Parecer 1.302/2001. Brasília: MEC/CNE. 2001

BRASIL. Indicadores de Qualidade da Educação Superior 2015. Brasília: INEP, 2015.

BRASIL. Resolução nº 1, de 18 de fevereiro de 2002. Brasília: MEC/CNE, 2002.

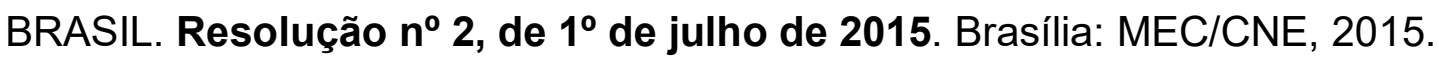

BRASIL. Sistema Nacional de Avaliação da Educação Superior - Sinaes. Brasília: INEP, 2015.

BRASIL. Base Nacional Comum Curricular. Brasília: MEC/CNE, 2018.

BRASIL. Lei de Diretrizes e Bases da educação Nacional/Lei 9.394/1996. Brasília, 1996.

BRASIL. Parâmetros Curriculares Nacionais: matemática/Secretaria de Educação. Educação Fundamental. Brasília: MEC/ SEF, 1998.

BRASIL. Parâmetros Curriculares Nacionais: matemática/Secretaria de Educação. Ensino Médio. Brasília: MEC/SEB, 2000. 
BROUSSEAU, G. Introdução ao estudo das situações didáticas: conteúdos e métodos de ensino. São Paulo: Ática, 2008

CARAÇA, B. J. Conceitos Fundamentais da matemática. Lisboa: Fotogravura Nacional, 1951.

CEDRO, W. L. O motivo e a atividade de aprendizagem do professor de matemática: uma perspectiva histórico-cultural. 2008, 242f. Tese (Doutorado em Educação) Faculdade de Educação, Universidade de São Paulo, São Paulo. 2008.

CEDRO, W. L.; MOURA, M. O. Experimento didáctico: un camino metodológico para la investigación en la educación matemática. Unión (San Cristobal de La Laguna), v. junio, p. 53-63, 2010.

CEDRO, W. L.; MOURA, M. O. Possibilidades metodológicas na pesquisa em educação matemática: o experimento didático. In: Revista Educativa. Goiânia, v. 19, n. 1, p. 121-138, jan./abr. 2016.

CHEVALLARD, Y. La Transposicion Didactica: del saber sabio al saber enseñado. $1^{\text {a }}$ ed. Argentina: La Pensée Sauvage,1991.

D’AMBRÓSIO, B. S. A Evolução da Resolução de Problemas no Currículo Matemático. In: I Seminário em Resolução de Problemas, 2008, Rio Claro. Anais do I SERP. Rio Claro, 2008. Disponível em: $<$ http://www.rc.unesp.br/serp/trabalhos_completos/completo1.pdf>. Acesso em 18 de novembro de 2013.

DANTE, L. R. Didática da Resolução de Problemas em matemática. São Paulo: Ática, 1998.

DANTE, Luiz Roberto. Formulação e Resolução de problemas de matemática: Teoria e prática. São Paulo: Ática, $1^{\text {a }}$ ed. 2009.

DAVÍDOV, V.; MARKÓVA, A. La concepcion de la actividad de estudio de los escolares. In: DAVYDOV, V. SHUARE (org.) La psicologia evolutiva y pedagogia em la URSS. Moscú: Progresso, 1987.

DAVYDOV, V.V. Problems of developmental teaching - The experience of theoretical and experimental psychological research. In: Revista Soviet Education, August/VOL XXX, N 8, New York. 1988.

DELORS, J. Educação: um tesouro a descobrir. 2ed. São Paulo: Cortez Brasília, DF: MEC/UNESCO, 2003. 
http://www.ia.ufrrj.br/ppgea/conteudo/T1SF/Sandra/Os-quatro-pilares-daeducacao.pdf $>$. Acesso em 12 de novembro de 2018.

DIAS, M. S. Uma Atividade Orientadora de Ensino para abordar o Sistema de Numeração. In: Associação de Professores de matemática PROFMAT. Portugal, 2011. Disponível em: < http://www.apm.pt/files/_C40_4e71e43034195.pdf>. Acesso em 04 de março de 2017.

DUARTE, N. Formação do Indivíduo, Consciência e Alienação: O Ser Humano na Psicologia de A. N. Leontiev. Revista Cadernos Cedes A Psicologia de A N Leontiev e a Educação na Sociedade Contemporânea, Cedes - Campinas - SP, v. 24, n.62, p. 4463, 2004.

DUARTE, N. Vigotski e o "aprender a aprender": crítica às apropriações neoliberais e pós-modernas da teoria vigotskiana. 2. ed. rev. e ampl. - Campinas, SP: Autores Associados , 2011.

EVES, H. Introdução à história da matemática. Trad. Hygino H. Domingues. Campinas: Editora da Unicamp, 2011.

FIORENTINI, D.; CRECCI, V. M. Aprendizagem docente na formação inicial mediante análise de práticas de ensinar aprender matemática. In: LOPES, C. E. ; TRALDI, A. ; FERREIRA A. C. (org.). A Formação do professor que ensina matemática: aprendizagem docente e políticas públicas. Campinas, SP: Mercado de Letras, 2015.

FIORENTINI, D.; LORENZATO, S. A. Investigação em Educação matemática: percursos teóricos e metodológicos. 1. ed. Campinas: Autores Associados, 2007. $226 p$.

GATTI, B. A. Formação de professores no brasil: características e problemas. In: Revista Educação \& Sociedade, Campinas, v. 31, n. 113, p. 1355-1379, out.-dez. 2010.

GATTI, B.A.; NUNES, M.M.R. (Org.). Formação de professores para o ensino fundamental: estudo de currículos das licenciaturas em Pedagogia, Língua Português, matemática e Ciências Biológicas. Textos FCC, São Paulo, v. 29, 2009. $155 p$.

GAMA, R. P. ; SOUSA, M. C. . Elementos estruturantes que podem promover a construção do estágio compartilhado na licenciatura em matemática. In: Celi Espasandin Lopes; Armando Traldi; Ana Cristina Ferreira. (Org.). O Estágio na formação inicial do professor que ensina matemática. v. 9, 1ed.Campinas: Mercado de letras, 2015, p. 11-42. 
GUEDES, N. C.; FERREIRA, M. S. História e construção da profissionalização nos cursos de licenciaturas. In: II Congresso de História da Educação. Natal-BRA: Congresso de História da Educação. 2002.

GUIMARÃES, H. M. Jeremy Kilpatrick on Pólya: An interview. In: RIPEM - Revista Internacional de Pesquisa em Educação matemática, vol. 1, pp. 68-84. 2011.

IFSP. Projeto Pedagógico de Curso - Licenciatura em matemática. IFSP - Câmpus São Paulo: São Paulo, 2011.

JOHN-STEINER, V.; SOUBERMAN, E. Posfácio. In: A formação social da mente. Liev S. Vygotsky. São Paulo: Martins Fontes, p 161-179, 1991.

LeONTIEV, A. Atividade, Consciência e Personalidade. In: Domínio Público. Tradução: Maria Silvia Cintra Martins. 1983. Disponível em: $<$ http://www.dominiopublico.gov.br/download/texto/ma000004.pdf >. Acesso em $07 \mathrm{de}$ março de 2017.

LEONTIEV, A. O desenvolvimento do psiquismo. Lisboa: Horizonte, 1978. pp: 261284.

LOPES, C. E.; TRALDI, A.; FERREIRA A. C. Práticas e aprendizagens docentes: a busca de um panorama sobre a formação de educadores matemáticos. In: LOPES, C. E.; TRALDI, A.; FERREIRA A. C. (org.). A Formação do professor que ensina matemática: aprendizagem docente e políticas públicas. Campinas, SP: Mercado de Letras, 2015.

MARTINS, L. M.. As aparências enganam: divergências entre o materialismo histórico dialético e as abordagens qualitativas de pesquisa. GT: Filosofia da Educação/17. UNESP, 2006. Disponível em: < https://goo.gl/W5GbjS>. Link encurtado. Acesso em 01 de agosto de 2017.

MARX, K. O capital: crítica da economia política. Livro I. São Paulo: Boitempo, $2^{\mathrm{a}}$ ed., 2017.

MELLO, V. M.. Estratégias para Elaboração de Problemas Matemáticos para o Ensino Médio. 2016. Dissertação (Mestrado em matemática) - Universidade Federal da Bahia. Salvador. 2016.

MORETTI, V. D. Professores de matemática em Atividade de Ensino. Uma perspectiva histórico-cultural para a formação. 2007. 208f. Tese (Doutorado em Educação) - Faculdade de Educação - Universidade de São Paulo, São Paulo. 2007. 
MORETTI, V. D.; MARTINS, E.; SOUZA, F. D. Método Histórico-Dialético, Teoria Histórico-Cultural e Educação: Algumas apropriações em pesquisas sobre formação de professores que ensinam matemática. In: Moretti, V. D.; Cedro, W.L.. (Org.). Educação matemática e a Teoria Histórico-Cultural: um Olhar sobre as Pesquisas. 1ed.Campinas: Mercado de Letras, p. 25-59, 2017.

MORETTI, V. D.; MOURA, M. O. Problemas de matemática em atividade de ensino: contribuições da perspectiva histórico-cultural para a formação docente. Ciência e Educação, Bauru, v.17, n. 2, 2011.

MORETTI, V. D.; RADFORD, L. História do Conceito culturalmente significada e a Organização da Atividade de Ensino de matemática. In: VI Sipem - Simpósio Internacional de Pesquisa em Educação matemática, 2015, Pirenópolis. Anais do VI Sipem, 2015.

MORETTI, V. D. ; MARTINS, E. ; SOUZA, F. D. Dialectical and historical method, cultural-historical theory and education: some appropriation in research on education of teachers who teach mathematics. In: RIPEM - International Journal for Research in Mathematics Education, v. 6, n. 2, 2016b. Disponível em: < http://www.sbembrasil.org.br/ripem/index.php/ripem/article/view/189>. Acesso em 21 de outubro de 2016.

MORETTI, V. D. ; SOUZA, N. M. M. Educação matemática nos anos iniciais do Ensino Fundamental. $1^{\mathrm{a}}$ ed. Vol. 1. São Paulo: Cortez Editora, 2015. 216p.

MORETTI, V. D. O Problema Lógico-Histórico, Aprendizagem Conceitual e Formação de Professores de matemática. In: POIÉSIS - Revista do Programa de PósGraduação em Educação (Unisul), v. 8, p. 29-44, 2014. Disponível em < http://migre.me/ukzsK>. Acesso em 29 de junho de 2016.

MOURA, M. O. ; ARAUJO, E. S. ; SERRAO, M. I. B. Atividade Orientadora de Ensino: fundamentos. LINHAS CRÍTICAS (UNB), v. 24, pp. 339-358, 2018

MOURA, M. O. Atividade Orientadora de Ensino: unidade entre ensino e aprendizagem. Diálogo Educacional, Curitiba, v. 10, n. 29, pp. 205-229, jan-abr. 2010.

MOURA, M. O. Metodologia de pesquisa em educação matemática: tendência ou opção? In: ENCONTRO BRASILEIRO DE ESTUDANTES DE PÓS-GRADUAÇÃO EM EDUCAÇÃO MATEMÁTICA, 6, 2002, Campinas, SP. Anais... Campinas: Gráfica da FE. pp. 40- 45, 2002. 
MOURA, M. O. O educador matemático na coletividade de formação: uma experiência com a escola pública. Tese (Livre Docência em Metodologia do Ensino de matemática) - Faculdade de Educação. Universidade de São Paulo, São Paulo. 2000.

MOURA, M. O. O estágio na formação compartilhada do professor: retratos de uma experiência. 1. ed. São Paulo: Faculdade de Educação, 1999. 146p .

MOURA, M. O. ; SFORNI, M. S. F. ; ARAUJO, E. S. Objetivação e apropriação de conhecimentos na atividade. Teoria e Prática da Educação, v. 14, pp. 39-50, 2011.

MOURA, M. O. ; SFORNI, M. S. F. ; LOPES, A. R. L. V. A objetivação do ensino e o desenvolvimento do modo geral da aprendizagem da atividade pedagógica. In: MOURA, M. O. (org.) Educação escolar e pesquisa na teoria histórico-cultural. $1^{\mathrm{a}} \mathrm{ed}$. Vol. 1. São Paulo: Edições Loyola, 2017. pp 71-99.

MOURA, M. O.; LANNER MOURA, A. R. A atividade de ensino de matemática como desencadeadora da formação do professor. In: III Congresso Iberoamericano de Educação Matematica - CIBEM, 1999, Caracas. Resúmenes do III Congresso Iberoamericano de Educação Matematica - CIBEM. Caracas: Asovemat, v. 1. p. 497-507, 1998.

NASCIMENTO, R. Comentários sobre as Teorias da Mente e a Psicologia de Herbart na História da Psicologia da Educação. Aprender (Vitória da Conquista), Vitória da Conquista/BA, v. 1, p. 41-48, 2003.

OLIVEIRA, B. A dialética do singular-particular-universal. In: V Encontro de Psicologia Social Comunitária: O método materialista histórico-dialético. Bauru, SP: UNESP, 2001. Disponível em:

http://stoa.usp.br/mpp5004/files/1/18602/ADialeticaDoSingularParticular>. Acesso em 12 de outubro de 2018.

OLIVEIRA, M. K. Vygotsky: Aprendizado e desenvolvimento: um processo sóciohistórico. São Paulo: Scipione, 1993.

ONUCHIC, L. R.. Ensino-aprendizagem de matemática através da resolução de Problemas. In: Maria Aparecida Viggiani Bicudo. (Org.). Perspectivas em Educação matemática. São Paulo: Editora da UNESP, v. único, p. 199-218, 1999.

ONUCHIC, L. R.; ANDRADE, C. P. Perspectiva para Resolução de Problemas no GTERP. In: Lourdes de la Rosa Onuchic; Luiz Carlos Leal Jr; Márcio Pironel. (Org.). Perrpectiva para Resolução de Problemas. 1ed.São Paulo: Livraria da Física, p. 433-466, 2017. 
ONUCHIC, L. R.; LEAL JR, L. C. Ensino e Aprendizagem de matemática Através da Resolução de Problemas Como Prática Sociointeracionista. In: BOLEMA : Boletim de Educação matemática (Online), v. 29, p. 955-978, 2015. Disponível em: < http://www.scielo.br/pdf/bolema/v29n53/1980-4415-bolema-29-53-0955.pdf>. Acesso em 28 de novembro de 2018.

ONUCHIC, L. R. Uma História da Resolução de Problemas no Brasil e no Mundo. In: I Seminário em Resolução de Problemas, 2008, Rio Claro. Anais do I SERP. Rio Claro, 2008. v. único. p. 1-15.

PANOSSIAN, M. L.; CEDRO, W. L.; SOUSA, M. C. Do movimento lógico e histórico à organização do ensino: o percurso dos conceitos algébricos. 1. ed. Campinas: Mercado de letras, v. 01. 184p., 2014.

PIMENTA, S. G.; LIMA, M. S. L. Estágio e Docência. São Paulo: Cortez, 2004.

PIMENTA, S. G.; LIMA, M. S. L. Estágio e docência: diferentes concepções. In: Congresso Internacional de Formação Continuada e Profissionalização Docente, 2005, Natal. Anais do Congresso Internacional de Formação Continuada e Profissionalização Docente. Natal: UFP, 2005.

POLYA, G. A arte de resolver problemas. Trad. e adapt.: Heitor Lisboa de Araújo. Rio de Janeiro: Interciência, 1995.

RADFORD, L. Cognição matemática: história, antropologia e epistemologia. São Paulo: Livraria da Física, 2011. (Sociedade Brasileira de História da matemática).

REGO. T. C. Vygotsky: Uma perspectiva histórico-cultural da educação. $15^{\circ} \mathrm{Ed}$. Petrópolis: Vozes, 2010.

RIBEIRO, F. D. A formação do professor-educador matemáticos em cursos de Licenciatura em matemática. 1999. 132p. Dissertação (Mestrado em Educação). PUCPR, Curitiba.1999.

RIGON, A. J. ; ASBAHR, F. S. F. ; MORETTI, V. D. Sobre o processo de Humanização. In: MOURA, Manoel Oriosvaldo de (Org.) A atividade pedagógica na teoria Históricocultural. $2^{\mathrm{a}}$ ed. Campinas, SP: Autores Associados, 2016.

RIGON, A. J. ; BERNARDES, M. E. M. ; MORETTI, V. D. ; CEDRO, W. L. O desenvolvimento psíquico e o processo educativo. In: MOURA, Manoel Oriosvaldo de (Org.) A atividade pedagógica na teoria Histórico-cultural. $2^{\mathrm{a}}$ ed. Campinas, SP: Autores Associados, 2016. 
ROBERT, J. A origem do dinheiro. 2. ed. São Paulo: Global, 1989.

ROQUE, T. História da matemática: uma visão crítica, desfazendo mitos e lendas. Rio de Janeiro: Zahar, 2012.

SACRISTÁN, J. G. Consciência e Ação sobre a Prática como Libertação Profissional dos Professores. In: NÓVOA, A. Profissão Professor (Org.). Portugal: Porto Editora, 1991. pp. 63-92.

SANTOS, G. L. da C. Educação financeira: a matemática financeira sob nova perspectiva. 2005. Dissertação (Mestrado em Educação para a Ciência) - Faculdade de Ciências, Universidade Estadual Paulista - UNESP: Bauru, 2005.

SANTOS, I. B. Edward Lee Thorndike e a conformação de um novo padrão pedagógico para o ensino da matemática (Estados Unidos, primeiras décadas do século XX). 2006. 283 f. Tese (Doutorado em Educação: História, Política e sociedade). Pontifícia Universidade Católica, São Paulo. 2006.

SAVIANI, D. Educação: do senso comum à consciência filosófica. 13. ed. Campinas: Autores Associados, 2000

SILVA, M. H. M. Análise Histórica do Conceito de Função. In: Caderno de Licenciatura em matemática, $n^{\circ} 2$, ano 2, 1999. pp. 29-33.

SILVA, M. M. ; CEDRO, W. L. O estágio supervisionado e a licenciatura em matemática: as particularidades de uma proposta de aprendizagem da docência. In: Celi Espasandin Lopes; Armando Traldi; Ana Cristina Ferreira. (Org.). O Estágio na formação inicial do professor que ensina matemática. 1ed.Campinas, SP: mercado de letras, 2015, v. 1, p. 43-80.

SMOLE, K. C. S.; DINIZ, M. I. S. V. matemática: ensino médio. Volume 3. $3^{\text {a }}$ série $-3^{a}$ ed. reformulada. São Paulo: Saraiva, 2003. p. 303.

SOARES, M. Letramento e alfabetização: as muitas facetas. In: XXVI Reunião Anual da ANPED, Minas Gerais, 2003. Disponível em: <http://www.scielo.br/pdf/rbedu/n25/n25a01.pdf>. Acesso em 14 de maio de 2019.

SOARES, M. Alfabetização e letramento. $5^{\mathrm{a}}$ Ed. São Paulo: Contexto, 2007.

SOUZA, L. T. C. Estratégias para Elaboração de Problemas Matemáticos para o Ensino Médio. 2016. 85f. Dissertação (Mestrado Profissional em matemática em Rede Nacional). Instituto de matemática, Universidade Federal da Bahia, Salvador. 2016. 
STANIC, G. M. A; KILPATRICK, J. Perspectivas históricas da resolução de problemas no currículo de matemática. The teaching and assessment of mathematical problem solving, Reston, VA: NCTM e Lawrence Erlbaum, 1989.

TEIXEIRA, E. Vigotski e o materialismo dialético: uma introdução aos fundamentos filosóficos da Psicologia Histórico-cultural. Pato Branco, PR: FADEP, 2005.

THORNDIKE, E. L. A Nova metodologia da Aritmética. Tradução: Anadyr Coelho. Porto Alegre, RS: Edições Globo, 1936. 297p.

VÁZQUEZ, A. S. Filosofía de la práxis. México: Fondo de Cultura Económica, 1980.

VIRGENS, W. P. A resolução de problemas de aritmética no ensino primário: um estudo das mudanças no ideário pedagógico (1920-1940). 2014. 86f. Dissertação (Mestrado em Educação e Saúde na infância e na adolescência). Universidade Federal de São Paulo, São Paulo. 2014.

VYGOTSKY, L.S. A construção do pensamento e da linguagem. São Paulo, SP: Martins Fontes, 2001.

VYGOTSKY, L.S. A formação social da mente. São Paulo: Martins Fontes, 1991. 


\section{APÊNDICES}




\section{Apêndice 1: O Problema de João Napião}

João Napião é aluno do primeiro ano do Ensino Médio de uma escola e viu na internet um artigo com o título "Transforme multiplicações em adições e divisões em subtrações e resolva todos os seus problemas". Curioso, ele abriu o link e se deparou com uma pequena tabela que era chamada no site de "cartão mágico". O "cartão mágico" do site está reproduzido abaixo:

\begin{tabular}{|c|c|c|c|}
\hline Fatores & Gol & Fatores & Gol \\
\hline 2 & 1 & 2.048 & 11 \\
\hline 4 & 2 & 4.096 & 12 \\
\hline 8 & 3 & 8.192 & 13 \\
\hline 16 & 4 & 16.384 & 14 \\
\hline 32 & 5 & 32.768 & 15 \\
\hline 64 & 6 & 65.536 & 16 \\
\hline 128 & 7 & 131.072 & 17 \\
\hline 256 & 8 & 262.144 & 18 \\
\hline 512 & 9 & 524.288 & 19 \\
\hline 1.024 & 10 & 1.048 .576 & 20 \\
\hline
\end{tabular}

A explicação no artigo garantia que para multiplicar quaisquer FATORES bastava somar os números GOL correspondentes e verificar o FATOR que corresponderia a essa soma. Por exemplo, para multiplicar $512 \times 32$, basta notar que o GOL de 512 é 9 e que o GOL de 32 é 5 . Somando-se os números GOL temos: $9+5=14$. O número GOL 14 , por sua vez, corresponde ao FATOR 16.384, então 512 x $32=16.384$.

João Napião verificou essa constatação e concluiu que ela é verdadeira.

Da mesma forma, de acordo com o artigo, para dividir dois FATORES quaisquer, bastava subtrair os respectivos números GOL e, da mesma forma, o número GOL correspondente à essa diferença remeteria ao quociente. Era estabelecida a ressalva que, nessa "mágica", apenas divisões com quociente maior que 1 poderiam ser realizadas. Dessa forma, para dividir 65.536 por 1.024, bastava subtrair 10 (GOL de 1.024) de 16 (GOL de 65.536), encontrando 6. Como 6 é o número GOL de 64, então, $65.536 \div 1.024=64$.

Mais uma vez a conferência de Napião verificou que a conta estava correta.

Intrigado, João pôs-se a pensar sobre a razão pela qual essa "mágica" sempre acontece. 
> Ajude-o, mostrando as razões pelas quais essa característica dos números do "cartão mágico" sempre ajuda a transformar as multiplicações dos FATORES do cartão em adições dos GOL e o GOL da soma representa o produto dos FATORES. Faça o mesmo para verificar as razões da relação entre divisões em subtrações.

Durante sua investigação, João percebeu que a "mágica" só podia ser realizada se os FATORES que deseja multiplicar estiverem presentes no cartão. Perguntou-se, então se poderia utilizar as mesmas ideias para multiplicar, por exemplo, $81 \times 729$, que são FATORES que não estavam no cartão.

$>$ Como ele poderia proceder para encontrar esse produto, seguindo a mesma regra do cartão conhecido?

Empolgado, João decidiu pensar se seria possível a construção de um "cartão mágico" que pudesse calcular o produto de quaisquer números.

Vamos ajudar João nesse desafio. Se você conseguir calcule os valores do GOL de 2 e do GOL de 3 . Use, pelo menos, 3 casas decimais, explicitando cada etapa do cálculo. 


\section{Apêndice 2: Tabela Solução do Desafio de João Napião}

Tabela: Raízes 2n -ésimas de 10.

\begin{tabular}{|c|c|c|c|}
\hline $\mathrm{n}$ & $\mathrm{m}=2^{\mathrm{n}}$ & $\mathrm{x}=\sqrt[m]{10}$ & $\log _{10} x=\frac{1}{m}$ \\
\hline 1 & 2 & 3,16228 & 0,500000 \\
\hline 2 & 4 & 1,77828 & 0,250000 \\
\hline 3 & 8 & 1,33352 & 0,125000 \\
\hline 4 & 16 & 1,15478 & 0,062500 \\
\hline 5 & 32 & 1,07461 & 0,031250 \\
\hline 6 & 64 & 1,03663 & 0,015625 \\
\hline 7 & 128 & 1,01815 & 0,007813 \\
\hline 8 & 256 & 1,00904 & 0,003906 \\
\hline 9 & 512 & 1,00451 & 0,001953 \\
\hline 10 & 1024 & 1,00225 & 0,000977 \\
\hline 11 & 2048 & 1,00112 & 0,000488 \\
\hline 12 & 4096 & 1,00056 & 0,000244 \\
\hline 13 & 8192 & 1,00028 & 0,000122 \\
\hline 14 & 16384 & 1,00014 & 0,000061 \\
\hline 15 & 32768 & 1,00007 & 0,000031 \\
\hline 16 & 65536 & 1,00004 & 0,000015 \\
\hline 17 & 131072 & 1,00002 & 0,000008 \\
\hline 18 & 262144 & 1,00001 & 0,000004 \\
\hline 19 & 524288 & 1,00000 & 0,000002 \\
\hline
\end{tabular}

Fonte: Elaborada pelo autor

A partir da compreensão da tabela, propusemos aos licenciandos que calculassem, sem calculadora, 


\section{Apêndice 3: Jogo de Adivinhação}

\section{Etapa 1: Adivinhando as quantidades de palitos ocultas}

\section{Jogador A}

\section{Desafio 1}

$\checkmark$ Guarde oito palitos no interior de uma caixinha de forma que seu colega não veja.

$\checkmark$ Coloque sobre a carteira com outros dois palitos ao lado.

$\checkmark$ Anuncie para o colega que no total há dez palitos sobre a carteira e peça para que ele "adivinhe" a quantidade de palitos que há dentro da caixinha.

\section{Desafio 2}

$\checkmark$ Guarde quatorze palitos no interior de uma caixinha de forma que seu colega não veja e coloque sobre a carteira.

$\checkmark$ Com o colega vendo e em voz alta, retire cinco palitos da caixinha e anuncie para o colega que sobraram nove palitos lá dentro.

$\checkmark$ Peça para que ele "adivinhe" quantos palitos haviam inicialmente dentro da caixinha.

\section{Desafio 3}

$\checkmark$ Pegue duas caixinhas, guarde seis palitos no interior de cada uma delas de forma que seu colega não veja.

$\checkmark$ Coloque-as em cima da carteira com outros oito palitos ao lado.

$\checkmark$ Anuncie para o colega que no total há vinte palitos e que em cada caixinha há quantidades iguais de palitos.

$\checkmark$ Peça para que ele "adivinhe" a quantidade de palitos dentro de cada caixinha.

\section{Desafio 4}

$\checkmark$ Guarde cinco palitos dentro de uma caixinha de forma que seu colega não veja, e a coloque em cima da carteira com um palito ao lado da caixinha.

$\checkmark$ Repita o procedimento colocando sobre a carteira outra caixinha com cinco palitos e um palito ao lado da caixinha.

$\checkmark$ Anuncie para o colega que no total há doze palitos e que em cada caixinha há quantidades iguais de palitos. 
$\checkmark$ Peça para que ele adivinhe a quantidade de palitos dentro de cada caixinha.

\section{Desafio 5}

$\checkmark$ Junte três caixinhas e deposite seis palitos no interior de cada uma delas, de forma que seu colega não veja.

$\checkmark$ Coloque-as no canto da carteira e diga para ele que as três caixinhas representam o todo.

$\checkmark$ Pegue outra caixinha, guarde seis palitos de forma que seu colega não veja e a coloque em cima da carteira com quatro palitos ao lado dessa caixinha.

$\checkmark$ Anuncie para o colega que há dez palitos no total e peça para que ele "adivinhe" a quantidade de palitos que há na caixinha e então pergunte quantos palitos há no todo (três caixinhas).

\section{Jogador B}

\section{Desafio 1}

$\checkmark$ Guarde dez palitos no interior de uma caixinha, de forma que seu colega não veja e a coloque sobre a carteira com outros cinco palitos ao lado.

$\checkmark$ Anuncie para o colega que no total há quinze palitos e peça para que ele "adivinhe" a quantidade de palitos que há dentro do caixinha

\section{Desafio 2}

$\checkmark$ Guarde quinze palitos no interior de uma caixinha de forma que seu colega não veja e a coloque sobre a carteira.

$\checkmark$ Com o colega vendo e em voz alta, retire sete palitos da caixinha e anuncie para o colega que sobraram oito palitos lá dentro.

$\checkmark$ Peça para que ele "adivinhe" quantos palitos haviam anteriormente dentro da caixinha.

\section{Desafio 3}

$\checkmark$ Pegue duas caixinhas, deposite sete palitos no interior de cada uma delas de forma que seu colega não veja e as coloque em cima da carteira com outros cinco palitos ao lado.

$\checkmark$ Anuncie para o colega que no total há dezenove palitos e que em cada caixinha há quantidades iguais de palitos. 
$\checkmark$ Peça para que ele "adivinhe" a quantidade de palitos dentro de cada caixinha.

\section{Desafio 4}

$\checkmark$ Guarde seis palitos dentro de uma caixinha de forma que seu colega não veja.

$\checkmark$ Coloque-a em cima da carteira com outros dois palitos ao lado.

$\checkmark$ Repita o procedimento colocando sobre a carteira outra caixinha com seis palitos e dois palitos ao lado da caixinha.

$\checkmark$ Anuncie para o colega que no total há dezesseis palitos e que em cada caixinha há quantidades iguais de palitos.

$\checkmark$ Peça para que ele adivinhe a quantidade de palitos dentro de cada caixinha.

\section{Desafio 5}

$\checkmark$ Junte duas caixinhas, guarde seis palitos no interior de cada uma delas de forma que seu colega não veja. Coloque-as no canto da carteira e diga para o colega que as duas caixinhas representam o todo.

$\checkmark$ Pegue outra caixinha, guarde seis palitos e a coloque em cima da carteira com cinco palitos ao lado.

$\checkmark$ Anuncie para o colega que há onze palitos no total e peça para que ele "adivinhe" a quantidade de palitos que há na caixinha e então pergunte quantos palitos há no todo (duas caixinhas).

\section{Etapa 2: Preparando enigmas}

\section{Jogador A}

\section{Desafio 1}
a) $x+3=8$
$\therefore x=5$
b) $x+4=10$
$\therefore x=6$
c) $x+8=15$
$\therefore x=7$

Desafio 2
a) $x-4=10$
$\therefore x=14$
b) $x-5=12$
$\therefore x=17$
c) $x-7=11$
$\therefore x=18$

Desafio 3
a) $2 x+5=17$
$\therefore x=6$ 

b) $3 x+4=19$
$\therefore x=5$
c) $2 x+10=26$
$\therefore x=8$

\section{Desafio 4}
a) $2(x+1)=8$
$\therefore x=3$
b) $2(x+4)=12$
$\therefore x=2$
C) $3(x+2)=18$
$\therefore x=4$

Jogador B

\section{Desafio 1}
a) $x+4=9$
$\therefore x=5$
b) $x+6=13$
$\therefore x=7$
c) $x+9=15$
$\therefore x=6$

\section{Desafio 2}
a) $x-3=5$
$\therefore x=8$
b) $x-6=10$
$\therefore x=16$
c) $x-9=11$
$\therefore x=20$

Desafio 3
a) $2 x+4=10$
$\therefore x=3$
b) $3 x+5=17$
$\therefore x=4$
c) $2 x+8=28$
$\therefore x=10$

\section{Desafio 4}
a) $2(x+1)=10$
$\therefore x=4$
b) $2(x+2)=14$
$\therefore x=5$
c) $3(x+3)=15$
$\therefore x=2$ 
ANEXOS 


\section{Anexo 1: A Carta Caitité}

lauip, fevereiro de 2010.

Caros colegas,

Como vocês sabem, estou em lauip, país maravilhoso, para conhecer os avanços dos seus acadêmicos em matemática. Já participei do primeiro seminário. O nosso tema foi a descoberta de um sistema de numeração de uma comunidade chamada Caitité.

Os renomados professores Ovatsug e Oiegres apresentaram as suas descobertas iniciais baseadas em escritas que parecem representar os bens de um rico senhor daquela comunidade. Os professores disseram que foi possível perceber que as quantidades de um a doze podem ser representadas da seguinte forma: $\odot,+, N, \odot$, (๑), (c), (CN, +I, +@ , ++, +N, NI. Descobriram também que o povo Caitité já tinha um símbolo para o zero: I.

Os professores mostram uma inscrição que apresentava a figura de um jegue seguida dos símbolos $+\mathrm{N} \odot$. Supomos que quem fez esta inscrição estava querendo comunicar o valor do jegue.

No próximo seminário pretendemos descobrir a lógica do sistema de numeração dos Caitités. Acreditamos que isso poderá trazer grande contribuição para entender a cultura desse povo.

Estou enviando-lhes esse resumo do que já presenciei porque sei o quanto vocês ficarão desafiados para encontrar uma solução geral para o problema que estamos investigando. Peço-Ihes que procurem descobrir qual o sistema de numeração dos Caitités, pois isso daria um grande prestígio à nossa academia. Se vocês conseguirem descobrir, escrevam, com os nossos numerais, quanto custa o jegue e escrevam também quanto seria 23 e 203 em escrita Caitité. Vocês podem mandar a resposta por e-mail, mas em março estarei com vocês para chegarmos a uma conclusão.

Forte abraço.

Fonte: MOURA, M. O. A Carta Caitité. In: DIAS, M. S. Uma Atividade Orientadora de Ensino para abordar o Sistema de Numeração. In: Associação de Professores de matemática PROFMAT. Portugal, 2011. Disponível em: < http://www.apm.pt/files/_C40_4e71e43034195.pdf>. Acesso em 04 de março de 2017. 


\section{Anexo 2: Autorização para realização de Pesquisa - IFSP}

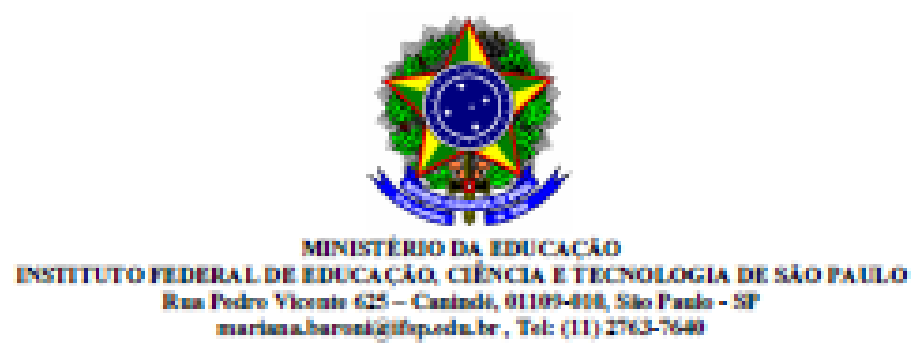

DECLARAÇÅo

Declaro, para fins de parecer consubstanciado do Comitê de Ética em Pesquisa da Faculdade de Educaçăo da Universidade de São Paulo, que autorizaremos a aplicação do projeto de pesquisa intitulado "Problemas desencadeadores de aprendizagem e a formação de professores de matemática: um experimento formativo em perspectiva histórico-cultural", no IFSP - Campus Săo Paulo, pelo pesquisador Wellington Pereira das Virgens, logo da emissäo do parecer definitivo do comitê supracitado como "Situaçäo Aprovada" do projeto e análise desta diretoria de acordo com procedimentos internos. A aceitaçẫo está condicionada ao cumprimento do pesquisador aos requisitos da Resolução CNS 466/2012 e suas complementares, comprometendo-se a utilizar os dados e materiais coletados, exclusivamente para os fins da pesquisa.

São Paulo, 06 de fevereiro de 2017.

Mosimantila prow

Mariana Pelissari Monteiro Aguiar Baroni

Diretora de Pesquisa, Extensão e Pós-Graduação

IFSP - Campus Săo Paulo

Portaria $n^{\circ} 264$ de 26/01/2015 


\title{
Anexo 3: Parecer Consubstanciado - Comitê de Ética em Pesquisa
}

\author{
USP - ESCOLA DE ARTES, \\ CIÊNCIAS E HUMANIDADES \\ DA UNIVERSIDADE DE SÃO
}

\section{PARECER CONSUBSTANCIADO DO CEP}

\section{DADOS DO PROJETO DE PESQUISA}

Titulo da Pesqulsa: Problemas Desencadeadores de Aprendlzagem e a formaçăo de professores de matematica

Pesqulsador: WELLINGTON PEREIRA DAS VIRGENS

Área Tematica:

Versao: 2

CAAE: 65187217.6 .0000 .5390

Institulçă Proponente:UNIVERSIDADE DE SAO PAULO

Patrocinador Principal: Financiamento Proprio

DADOS DO PARECER

Nümero do Parecer: 2.021 .021

Apresentaça do Projeto:

Trata-se de um projeto de pesqulsa de doutorado que propbe um experimento fomativo junto a estudantes do curso de Licenciatura em Matematica do Instituto Federal de Săo Paulo, a ser realizado durante as dsciplinas Pratica de Ensino III: Reflexăo da Pratica no Ensino e Pratica de Ensino IV: Trajetoria da Praxis bem como durante a realizaçăo do Estaglo Supervisionado. A partir do ferramental teorico-metodoioglco da teorla historico-cultural, considerando, entre outros, conceltos como necessidade, atividade e attvidade orlentadora de ensino - propostos por Vlgotski, Leontlev, Davidov, Moura e outros - os Icenclandos seráb convidados a estudar historicamente $0 s$ conceltos matematicos a serem aproprlados pelos alunos que participarăo de suas regenclas de estaglo supervisionado, para compreenderem os aspectos filogeneticos relacionados as necessidades humanas que originaram os referidos conceltos e poderem, entăo, elaborar Problemas desencadeadores de aprendizagem que coloquem os alunos dante das mesmas necessidades, visando o desenvolvimento ontogenetico. Segundo o pesqulsador, espera-se, como resultados da pesquisa, que $0 s$ licenclandos reconheçam as relaçbes entre o Problema e a necessidade, que origina 0 concelto, entrem em atividade de ensino ao mesmo tempo em que constituem um arcabouço tecrico e metodologico para medar 36 atividades de estudo dos alunos $\mathrm{e}$, alnda, que reconheçam a unidade daletica entre 06 aspectos logico e historico dos conceltos em

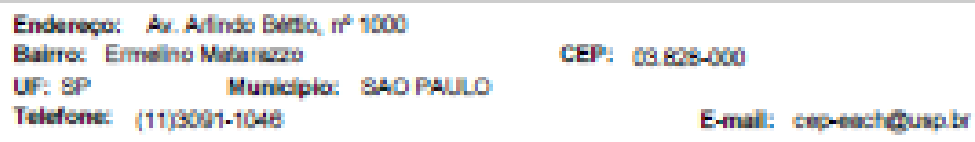




\section{USP - ESCOLA DE ARTES, CIËNCIAS E HUMANIDADES DA UNIVERSIDADE DE SÄO}

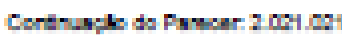

estudo para consoldaça dos recursos didaticos que nortearáo sua prads docente em beneficlo de uma educaga humanizadora em detrlmento de pratlcas tradclonals relaclonadas a resolucto de Problems, presentes no ensino de matematica.

Oojettro da Pesquilea:

Segundo o pesqulsador, os objettros da pesquisa sto:

obletvo Primario:

Medlar um experimento fomitho de formagto docente Iniclal com vistas a Investigacto sobre as manelras pelas quals o arcabouç teorico metodologlco histórico-cultural subeldla a elaboraço de Problemas Desencadeadores de Aprendlzagem por lloenclandos em matematca durante a reallzacto do Estaglo Supervislonado obrigatorío.

Objetwo Secundarlo:

Medlar, Junto aos llcenclandos, aproprlaples dos aportes teorlco-metodologlcos; Medlar a elaboracho dos Problems Desencadeadores de Aprendlzagem; Realzar a coleta e analse de dados parclals e recultados; Supervislonar as atvidades de regencla de Estaglo e coordenar debates, mudanças e permanenclas, de modo a responder a questáo de pesqulsa; Aprotundar-se no referendal blblografloo que fundamenta 06 aspectos

teoricos e metodologlcos adobados, Apresentar resultados parcals e finals a comunidade academica.

Avalaço dos Fiscos e Beneficlos:

os rlscos e beneicios da pesqulsa sto ldentificados pelo pesqulsador como:

Riscos:

A pesquls pode causar para cs particpantes algum desconforto de ordem dhersa, sobretudo em razbo da observaço de suas attvldades acedemicas ou para relatarem as attvidades realzadas durante a regencla em estaglo, anda que thes sefam garantidos o siglo e a Impessoaldade dos dados coletados.

Eeneflidos:

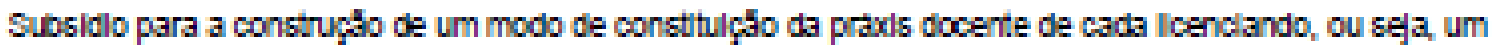
subeldlo para que os estudantes percebam naqullo que aprendem durante o curso como ferramentas potenclals para a concepcto de uma integracto entre teorla e pratica em beneficio de uma educaço plena e humanizada. A partir do expermento tomatvo, para alem da consoldacto do entendimento do Problema como processo desencadeador da atwidade de ensino e da athldade de aprendzagem e, portanto, como elwo organlzador da pratlca docente de matematica,

Endarsu: Ar Alinb Bdilu if liow

Balis: Emmainu Malarew

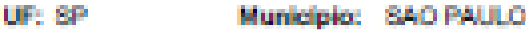

Telefore: 117poli-104t

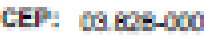

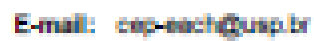




\section{USP - ESCOLA DE ARTES, CIÊNCIAS E HUMANIDADES DA UNIVERSIDADE DE SÃO}

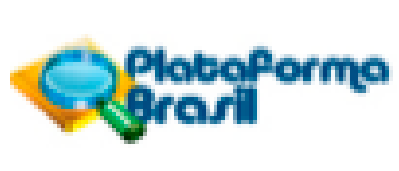

Corthus; do Pavoer 2021.021

espera-se enaltecer o papel dos Probiemas nos cursos de formaçăo inicalal e nas praticas docentes.

Comentarios $\theta$ Consideraçoes sobre a Pesqulsa:

Trata-se de uma pesquisa bem fundamentada e organizada dentro dos parametros eticos necessarios para com seres humanos.

Consideraçఠes sobre 08 Termos de apresentaçà obrigatorla:

Documento elaborado de forma adequada contendo todas as informaçbes necessarlas.

Recomendaçere:

Aprovaçấ Imediata do projeto de pesquisa

Conclus06e ou Pendenclas $\theta$ Llata de inadequaç0es:

Năo ha pendendas.

Consideraçoes Finals a criterio do CEP:

Este parecer fol edaborado bsesado nos documentos abalxo relacionados:

\begin{tabular}{|c|c|c|c|c|}
\hline Tipo Documento & Arquivo & Postagem & Alfior & Sltuaça \\
\hline $\begin{array}{l}\text { Informaçdes Basicas } \\
\text { do Proleto }\end{array}$ & $\begin{array}{l}\text { PB_INFORIACCOCES_BASICAS_DO_P } \\
\text { ROUETO 858983.pd }\end{array}$ & $\begin{array}{c}15 / 03 / 2017 \\
23: 31: 11 \\
\end{array}$ & & Acelto \\
\hline $\begin{array}{l}\text { TCLE/ Termos de } \\
\text { Assentimento / } \\
\text { Justifcativa de } \\
\text { Ausencla }\end{array}$ & TCLE_LCenclandos_Modelo.pd & $\begin{array}{l}15 / 03 / 2017 \\
23: 29: 42\end{array}$ & $\begin{array}{l}\text { WELUNGTON } \\
\text { PEREIRA DAS } \\
\text { VIRGENS }\end{array}$ & Acelto \\
\hline $\begin{array}{l}\text { TCLE/Termos de } \\
\text { Assentimento / } \\
\text { Justiflcativa de } \\
\text { Ausencla }\end{array}$ & Declaracaopesqusa_Welingion.pof' & $\begin{array}{l}15 / 02 / 2017 \\
10: 27: 29\end{array}$ & $\begin{array}{l}\text { WELUNGTON } \\
\text { PEREIRA DAS } \\
\text { VIRGENS }\end{array}$ & Acelto \\
\hline Folha de Rosto & Flcha_Plataforma_Brasll.por' & $\begin{array}{l}15 / 02 / 2017 \\
10: 26: 58\end{array}$ & $\begin{array}{l}\text { WELUNGTON } \\
\text { PERERA DAS } \\
\text { VRGENS }\end{array}$ & Acelto \\
\hline $\begin{array}{l}\text { Projeto Detalinado / } \\
\text { Erochura } \\
\text { Investigador }\end{array}$ & $\begin{array}{l}\text { Projeto_de_Pesquilsa_Doutorado_Welln } \\
\text { gton_Frnal.doc }\end{array}$ & $\begin{array}{l}29 / 01 / 2017 \\
17: 33: 42\end{array}$ & $\begin{array}{l}\text { WELUNGTON } \\
\text { PERERA DAS } \\
\text { VRGENS }\end{array}$ & celto \\
\hline
\end{tabular}

sItuaç30 do Parecer:

Aprovado

Neceselta Apreclação da CONEP:

Nấ

CEP: $09808-000$

Telefone: (11)3001-104e 


\section{USP - ESCOLA DE ARTES, CIÊNCIAS E HUMANIDADES DA UNIVERSIDADE DE SÃO}

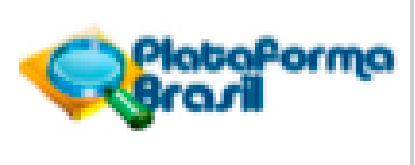

Corthus ib da Pavear 2.021 .021

SAO PAULO, 18 de Abnl de 2017

Assinado por:

Rosa Yuka Sato Chubact

(Coordenador)

Endereço: Av. Adindo Bettio $n^{6} 1000$

Bairrec Emsine Matarezos

UF: SP

Municipio: ShO Paulo

Telefone: (11)3001-104e
CEP: 0Q 808-000

E-mail: cep-eachauspob 
Anexo 4: Modelo TCLE

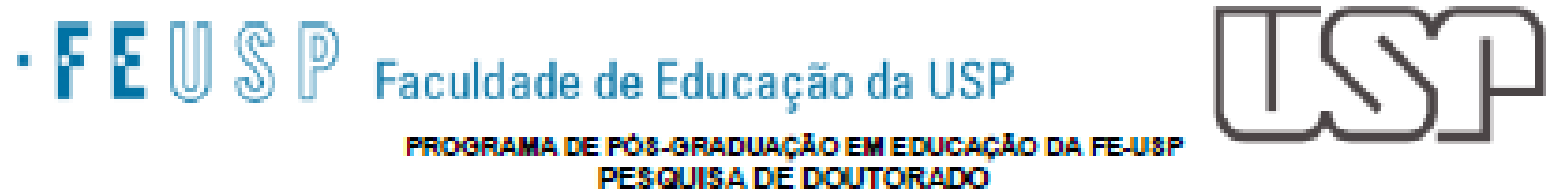

TERMO DE CONSENTIMIENTO LIVRE E ESCLARECIDO

Título da Pesquisa: Problemas Desencadeadores de Aprendizagem e a formação de professores de matemática: um experimento formativo em perspectiva histórico-cultural.

Nome do Pesquisador: Wellington Pereira das Virgens

1. Da natureza da pesquiva

Caro beraciando,

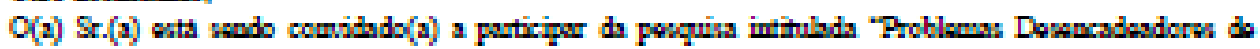

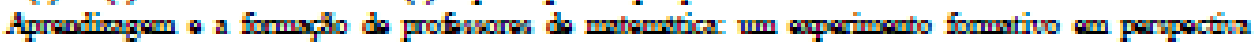

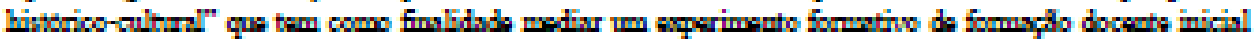

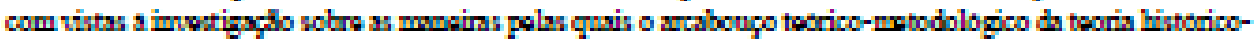

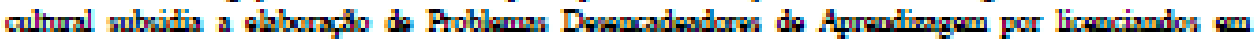

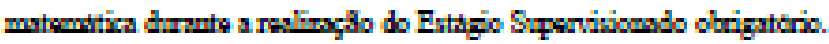

2. Dos participantes da pesquiva:

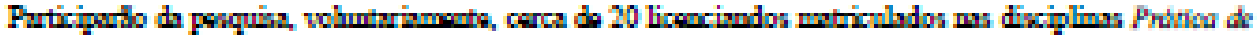

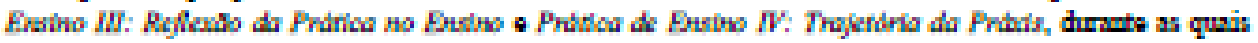

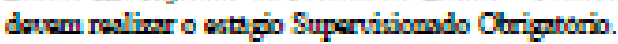

3. Do enrolvimento ma pesquis:

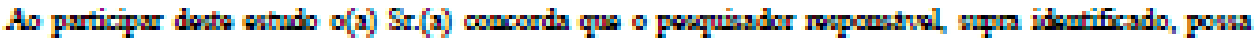

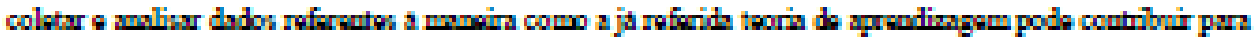

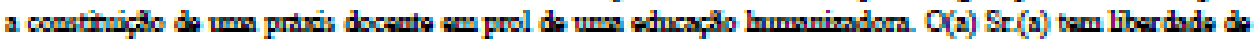

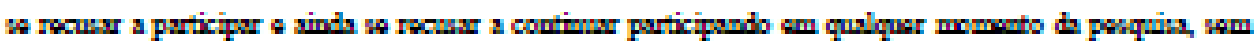

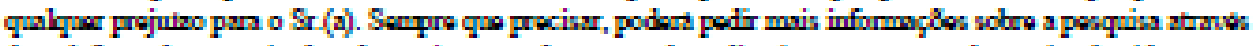
do telefoae do pesquisador do projeto on do gupo de pqlicativo para susurtphose (conhecido como

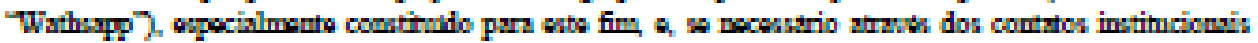

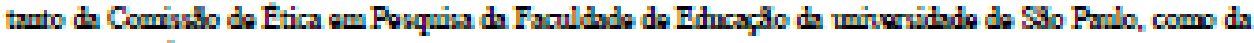
Cominaso de Etica em Perquisa do Instinto Foderal de Sso Paub.

4. Sobre a participaçio na pesquira:

So o Sr (a) consentir em participur da pesquins, devera participor don debaten acesca da tocria reforeaciads,

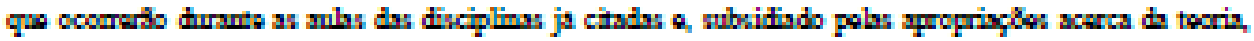

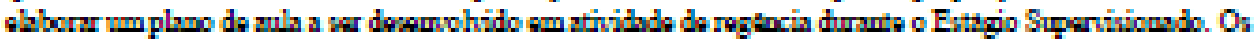

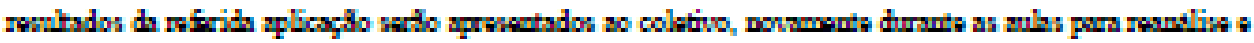

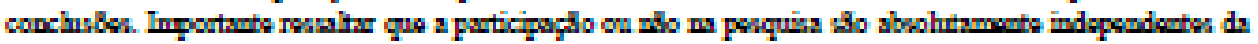

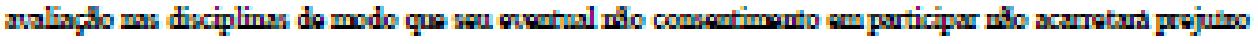
alsyum 30 sen denemperbo scadensico ma dixciplina.

5. Dos posstreis Rivcos e desconforto:

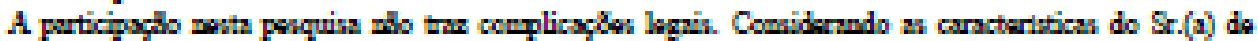

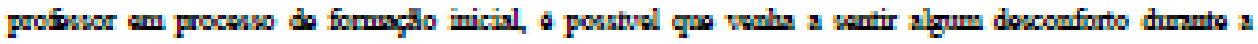

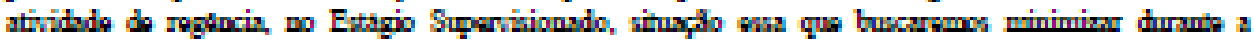

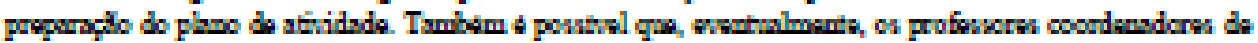

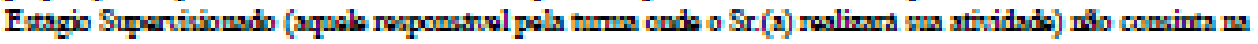

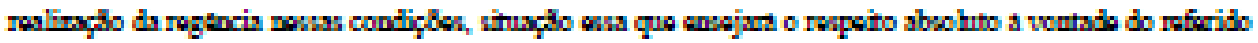

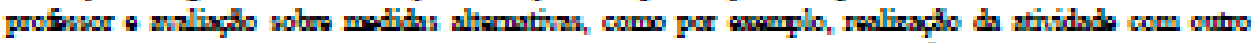

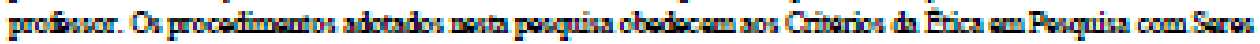

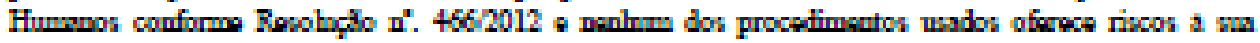
digridade.

6. Da coufidencialidade: 


\section{TERMO DE CONSENTIMENTO LIVRE E ESCLARECIDO}

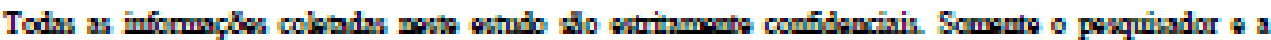

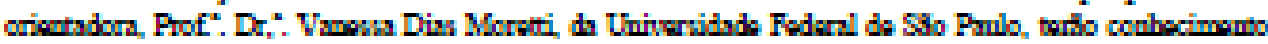

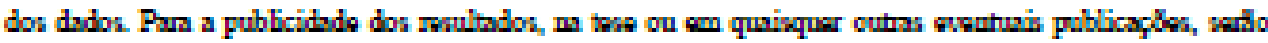
attelados aos dados preudonimos.

7. Dos Beseficios:

Ao purticipur denta penquisa o(a) $\mathrm{Sr}$ (a) tera como beneficio direto a oportmidado de raalizaplo das atividados

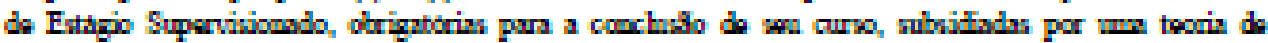

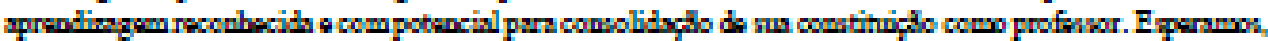

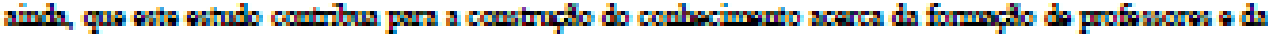

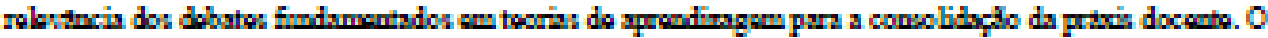
posqrisador se conqromete a divulgres os romalados obtidos.

8. Do pagimento:

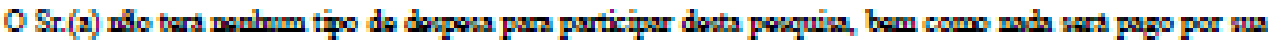
participaço.

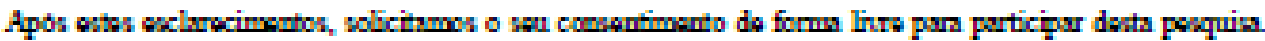
Portanto proseche, por fivor, os itans qae se wguem

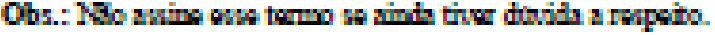

\section{Consentimento Livre e Esclarecido}

Em proatatrio

ahmo rogulanuente matriculado no carso de Liconcintura em Matomatica do IFSP, dechro, por maio denthe meu aceito em purticipar da porquias intitulada 'Problemes Desencadeadores de Aprendizagem e a formaçlo de professores de matematica: $=\mathrm{m}$ experimento formativo em perspectiva historico-cultura $\Gamma$, coordensda palo penquisador Wollingtoon Perein das Vrgens, aujo objetivo principal 4 medixr um enperimento fonmativo

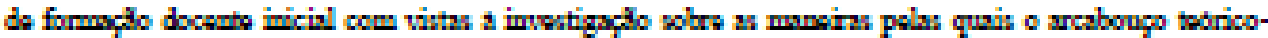
metodologico de tecria histtrico-cuhnal subside a alabonghlo de Problomss Desencadesdors de

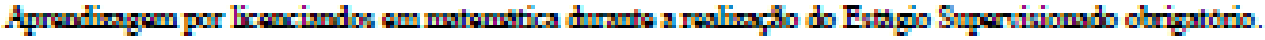

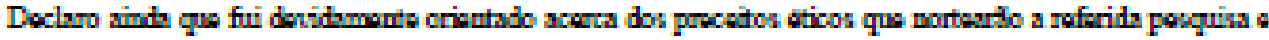
minha ciercia quanto aes rivcos a publicidede dos reaultados obtidos apos a conchuslo dos trabalbor.

Dados do Licenciando:

Nome:

Prontuánio:

São Paulo, de 2017 .

\section{Licenciando \\ Prontuário:}

R.G.: 